\title{
The Paleoproterozoic Structural History of Metamorphosed and Polydeformed Basement and Cover Rocks in the Ptarmigan Fiord Area, Baffin Island, Nunavut: A Tectonic Component of the Quebec-Baffin Segment of the Paleoproterozoic Trans-Hudson orogen
}

\author{
by
}

Timothy Chadwick, B.Sc.

A thesis submitted to the Faculty of Graduate Studies and Research in partial fulfillment of the requirements for the degree of Master of Science

Ottawa-Carleton Geoscience Centre and Department of Earth Sciences

Carleton University

Ottawa, Ontario

(c) 2017

Timothy Chadwick 


\section{FRONTISPIECE}

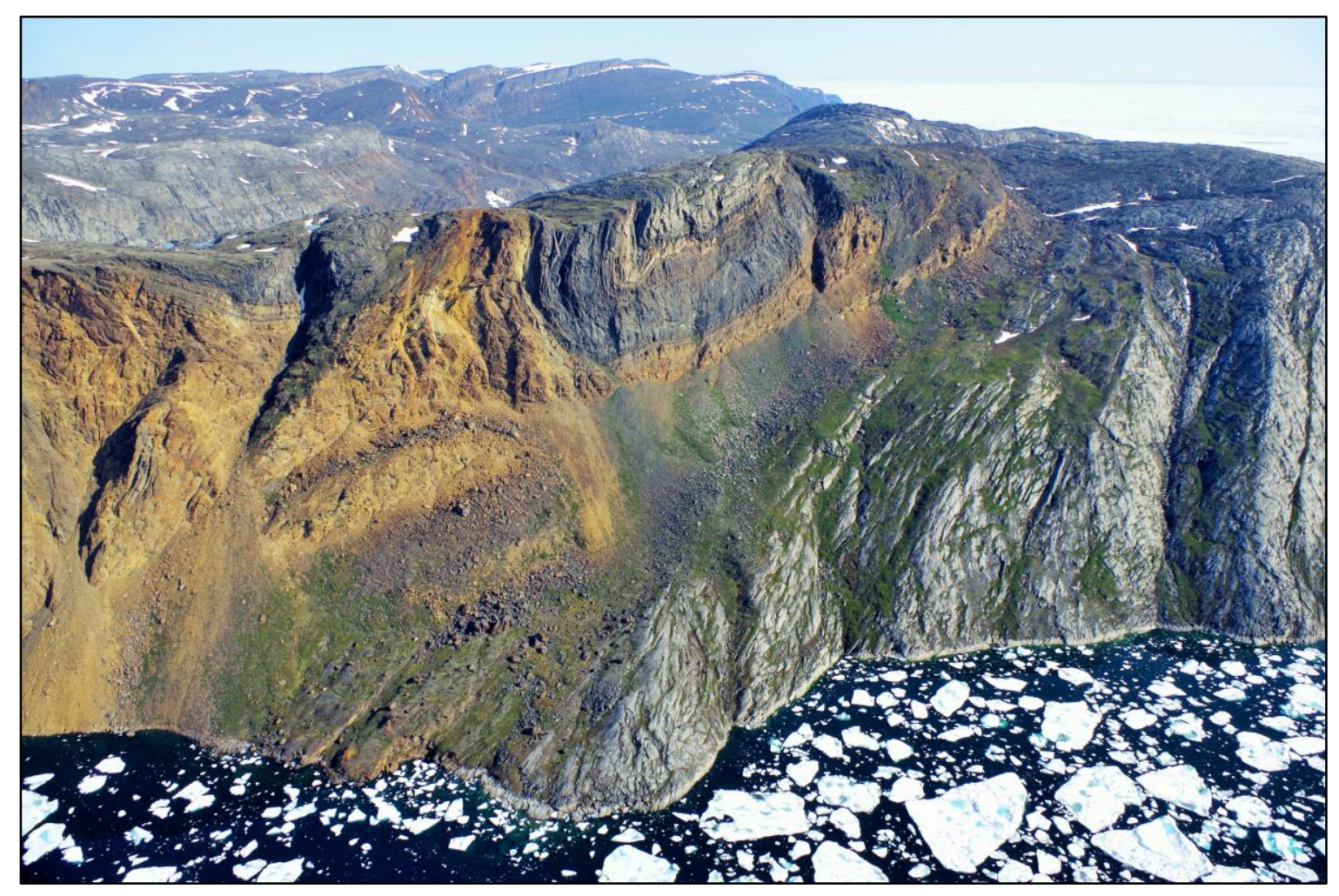

Ptarmigan Fiord, Nunavut

An aerial photograph taken from a helicopter along the southern arm of Ptarmigan Fiord, Hall Peninsula, Nunavut, looking north, of a cliff-side exposure of folded greyweathering basement rocks and rusty-brown weathering cover rocks. Large semicircular blocks of drift ice remained within the fiord for the duration of the 2015 field season due to an exceptionally cold winter and cool spring and summer temperatures. 


\begin{abstract}
The structural geometry and Paleoproterozoic deformation history of the Ptarmigan Fiord area is interpreted from mapping and structural analyses, integrated with published lithology, petrology and geochronology data. Early thrust repetition, of 80-200 m-thick sheets of Archean orthogneiss basement with Paleoproterozoic cover of the Lake Harbour Group, results in repeated basement-cover couplets. This was followed by $\mathrm{D}_{\mathrm{P} 2}$ penetrative transposition that occurred at amphibolite-facies conditions at ca. 1850-1820 Ma. The major structure in the SE part of the map is an upright $\sim \mathrm{NW}$ - striking, tight $\mathrm{F}_{2 b}$ syncline that folds three basement-cover couplets. The fold has a wavelength of $\sim 3 \mathrm{~km}$, occurs over a strike length of $\sim 11 \mathrm{~km}$, and has been refolded. The NW part of the map area comprises a NW-dipping panel of basement rocks and three basement-cover couplets. This NW-dipping panel was juxtaposed against the $\mathrm{F}_{2 \mathrm{~b}}$ syncline by a moderately NWdipping, $T_{3 c}$ reverse shear zone.
\end{abstract}




\section{ACKNOWLEDGEMENTS}

I would like to extend my gratitude and thanks to my thesis supervisors; Dr. Sharon Carr, Carleton University, and Dr. Marc St-Onge, Geological Survey of Canada, for their unwavering guidance, support, and willingness to share their expertise with me, both in and out of the field. I would also like to express my thanks to Dr. Owen Weller and Dr. Brendan Dyck for helping me map the field area, assisting me with the initial map compilation, and for sharing their knowledge with me through numerous discussions. I would also like to thank Dr. Dianne Skipton for providing me with GIS material relevant for this study, and for sharing her knowledge on metamorphism and deformation on Hall Peninsula, through numerous conversations.

Many thanks go to my field assistants; Dustin Liikane, Terry Milton, Sean NobleNowdluk, Tyler Rowe, and Angela Ford, for their perseverance and enthusiasm in the field. I would like to thank Jerry Nuttall from Universal Helicopters for his precision flying skills in the area, as well as our camp cook Debra Guilfoyle, for keeping us thoroughly nourished during the field season.

I am very grateful for the financial support this project received from the Geo-mapping for Energy and Minerals (GEM) program, Carleton University, and a Natural Sciences and Engineering Research Council of Canada Discovery Grant to S. Carr. I also thank Holly Steenkamp for securing thin sections for this project through the Strategic Investments in Northern Economic Development (SINED) program offered by the Canadian Northern Economic Development Agency (CanNor).

Lastly, I would like to thank family and friends for supporting me throughout the time spent on my master's degree. 


\section{ORIGINAL CONTRIBUTIONS}

Field mapping in the Ptarmigan Fiord area, northern Hall Peninsula, Nunavut, was conducted during the summer of 2015 while working as a bedrock mapping assistant for a Geological Survey of Canada regional mapping project in the South Baffin Island area. Work in the Ptarmigan Fiord area consisted of 1 week of geological mapping, at 1:40 000 scale, in an approximately 10 by $18 \mathrm{~km}$ field area bound by Ptarmigan Fiord to the east and south, Niante Harbour to the north, and Chidliak Bay to the west. Map 1 (back pocket).

Geological mapping, coupled with thin section petrography of representative samples, resulted in the characterization of a heterogeneous and variably deformed Archean orthogneiss basement complex. Some map units of Archean basement in the Ptarmigan Fiord area are similar to and likely correlate with metaigneous map units documented in the SW corner of NTS sheet 026A on Hall Peninsula (Figure A, Map 1; back pocket) by From et al. (2015; and references therein). Based on the similarities and correlation of units in the two areas, and geochronology studies by From et al. (2015) and Rayner (2015), the basement rocks record a complex, protracted (ca. 3209 to ca. $2682 \mathrm{Ma}$ ) emplacement, metamorphic and deformation history (Table 2.1). A Paleoproterozoic syenogranite pluton was identified in the western part of the map area that cross-cuts the basement foliation, but was not identified as an intrusion in the cover rocks.

The basement is nonconformably overlain by Paleoproterozoic metasedimentary rocks which are interpreted to have been deposited in proximal shallow-marine to more distal continental-shelf and slope-rise depositional settings. These depositional environments are inferred from the mapped tectonostratigraphy in the study area (Figure 2.1), which broadly correlates with the regional tectonostratigraphy of the Lake Harbour Group (Scott, 1997; St-Onge et al., 2006; Machado et al., 2013a and b; Steenkamp and St-Onge; 2014). 
A new digital geological map of the study area was compiled from an electronic database of 2015 mapping data, topographic data, and integrated legacy data, using ArcMap 10.2.2 GIS software. Cross-sections were constructed across map-scale structures in order to test and validate the map pattern; with corrections being made to the map pattern if structural inconsistencies were identified. An equal area stereonet analysis of map-scale folds was conducted in order to characterize the geometry of map-scale folds that govern the map pattern. Field orientation measurements, and estimated contact orientations based on structure contour analyses, were used for stereonet analyses of subdomains of the map area, which helped to sort out the effects of superposed folds. Three generations of folds were identified, including: 1) outcrop scale pre-to synthermal-peak intrafolial 'mature' folds that fold compositional layering; 2) outcrop-to-map-scale, upright, close to open 'immature' folds that fold contacts and transposition structures; and 3) outcrop-to-mapscale, upright, open to gentle folds that refold 'immature' folds and transposition structures (Table 3.1).

Strain and kinematic analyses, of micro-and-macroscopic structures in oriented basement samples, were conducted in order to characterize the nature of basement-cover contacts, and to assess the extent of penetrative deformation within the dominant basement rocks of the study area. Microstructural strain analyses of basement samples was hampered to some degree by the effects of annealing, which masked most high strain microstructures. Structural juxtaposition of older rocks over younger rocks is interpreted to be the result of early brittle thrusting ( $\mathrm{T}_{\mathrm{P}}$; Table 3.1) that occurred prior to or early in the metamorphic event, when basement and cover rocks were strong enough to translate as competent sheets. These thrust faults were then transposed into concordance with each other and with younger structures that formed during a strong overprinting tectonothermal event that occurred at amphibolite facies in the presence of anatexis at ca. 1850-1825 Ma (Table 4.1; Skipton et al., 2016). Strain localization occurred along thrust faults, as well other contacts and Archean structures, during the transposition event and resulted in 5-10 m-thick shear zones with mylonites. 
All components and results of this multistage research approach were integrated into a diagrammatic block model, which summarizes the 3D geometry of structures in the Ptarmigan Fiord area (Figure H, Map 1; back pocket). The 3D model was then integrated with known geochronological data from the regional study of northern Hall Peninsula to produce a 4D structural model and geological history of the study area (Table 4.1). 


\section{METHOD OF PRESENTATION}

The body of the thesis is presented in two chapters (Chapters 2-3). Each of the chapters addresses a separate topic of the geological evolution of the Ptarmigan Fiord area, located on Hall Peninsula, Nunavut. They are prefaced by an introduction (Chapter 1) and followed by a discussion (Chapter 4), summary of conclusions and future recommendations (Chapter 5).

Chapter 1 - Introduction to the study area and the purpose, objectives, rational of the study, as well as the methods used to achieve these goals. This chapter also introduces the Paleoproterozoic Trans-Hudson orogen, with emphasis on the Meta Incognita microcontinent which forms part of the Quebec-Baffin Island segment of the orogen. The regional geology of Hall Peninsula is introduced and presented in terms of an eastern amphibolite facies domain and a western granulite facies domain, followed by an introduction to the geology of the Ptarmigan Fiord area.

Chapter 2 - Geology of the Ptarmigan Fiord area, northern Hall Peninsula, Nunavut. The rock types of each map unit of the Ptarmigan Fiord area are described, protoliths are interpreted, and the tectonostratigraphy of the cover rocks are presented. Correlations are made between the Ptarmigan Fiord area assemblages and assemblages of the northern Hall Peninsula, based on similarities in lithology and lithostratigraphy.

Chapter 3 - Structural history, strain analysis, and kinematics of polyphase deformation in the Ptarmigan Fiord area. There are at least three generations of deformation preserved in the Ptarmigan Fiord map area. The geometry of the structures are described for each generation of deformation, ranging from map scale structures to microstructures found in thin section. Estimated timing constraints for each deformation event is then presented based on cross-cutting relationships and available geochronological data.

Chapter 4 - Discussion of possible models for tectonic evolution of the study area, comparison of structural style and inferred thermal regimes with regional studies, and 
significance of the findings for tectonic evolution of the northern Hall Peninsula

Chapter 5 - Summary of conclusions and recommendations for future work.

Maps and Appendices: A geological map sheet (Map 1) and station map (Map 2) of the Ptarmigan Fiord area are included in the back pocket. Maps are projected using NAD_1983_UTM_Zone_19N. 


\section{TABLE OF CONTENTS}

FRONTISPIECE ..........................................................................................................................................ii

ABSTRACT ............................................................................................................................................iii

ACKNOWLEDGEMENTS ............................................................................................................... iv

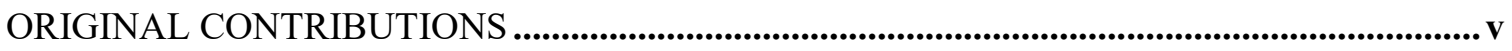

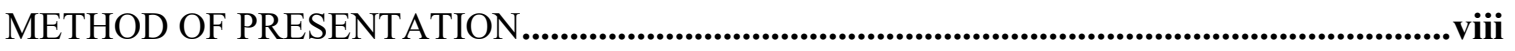

TABLE OF CONTENTS........................................................................................................................... $\mathbf{x}$

LIST OF APPENDICES ............................................................................................................................. xiv

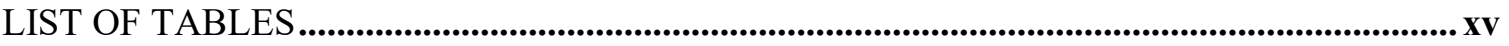

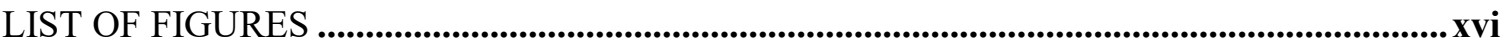

CHAPTER 1 - INTRODUCTION TO THE META INCOGNITA MICROCONTINENT AND GEOLOGICAL SETTING OF THE PTARMIGAN FIORD AREA .............................................1

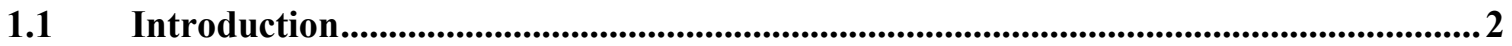

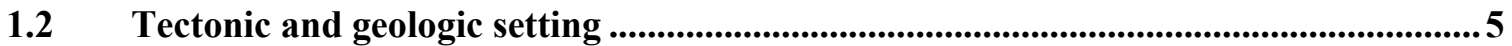

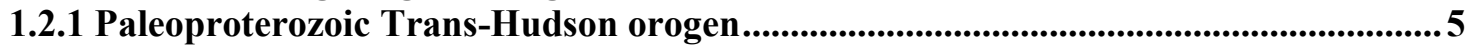

1.2.2 Meta Incognita microcontinent: Quebec-Baffin segment of the Trans Hudson

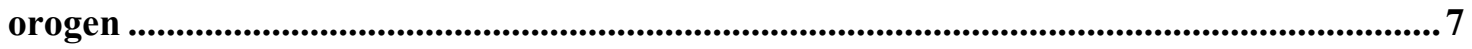

1.2.3 Geology of Hall Peninsula.........................................................................................................8

1.2.3.1 Previous mapping and geoscience studies ......................................................... 8

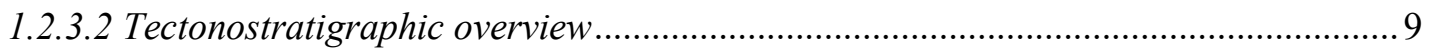

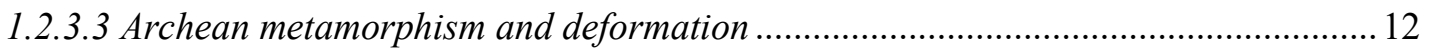

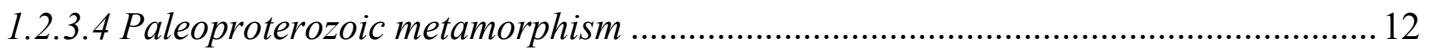

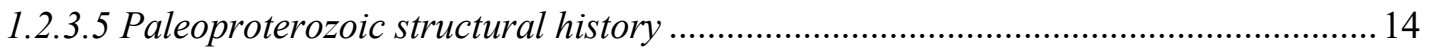

1.3 Geology of the Ptarmigan Fiord area............................................................................................. 16

CHAPTER 2 - GEOLOGY OF THE PTARMIGAN FIORD AREA, NORTHERN HALL

PENINSULA, NUNAVUT........................................................................................................................24

2.1 Introduction...........................................................................................................................................25

2.2 Map units .......................................................................................................................................................27

2.2.1 Archean orthogneissic basement complex (Unit 1) ....................................................227

2.2.1.1 Unit 1a: biotite-hornblende \pm orthopyroxene granodiorite ......................................2 28 


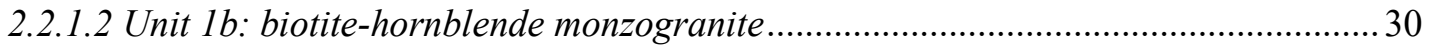

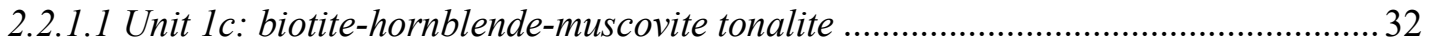

2.2.1.1 Unit 1d: hornblende-biotite quartz-diorite to gabbro .............................................. 34

2.2.2 Paleoproterozoic Lake Harbour Group cover rocks (Units 2 - 5) ............................... 35

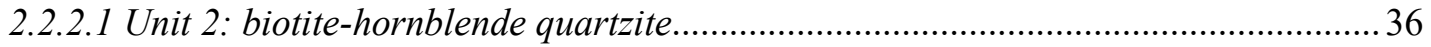

2.2.2.2 Unit 3: biotite-muscovite psammitic schist interlayered with garnet-sillimanite $\pm K$ -

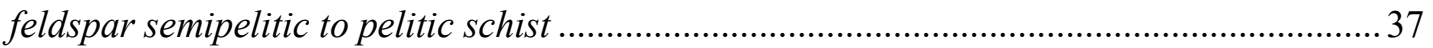

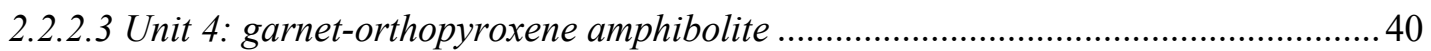

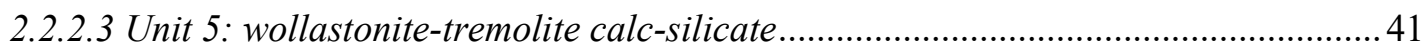

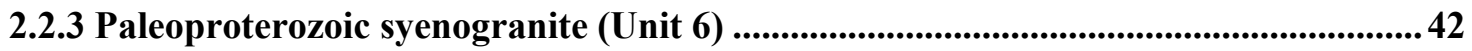

2.3 Interpretations and conclusions of Ptarmigan Fiord map units........................................ 43

2.3.1 Potential protoliths for unit 1 .................................................................................................... 43

2.3.2 Potential protoliths and depositional settings of cover rocks .....................................44

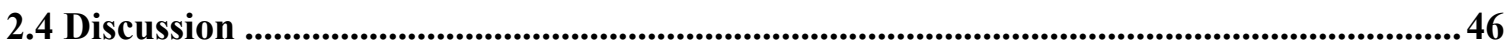

2.4.1 Correlation of units 1 and 6 with the regional basement complex .............................46

2.4.2 Correlation of units 2-5 with the regional Lake Harbour Group cover ......................50

2.5 Summary and conclusions..................................................................................................52

CHAPTER 3 - STRUCTURAL HISTORY, STRAIN ANALYSIS, AND KINEMATICS OF

POLYPHASE DEFORMATION IN THE PTARMIGAN FIORD AREA ......................................86

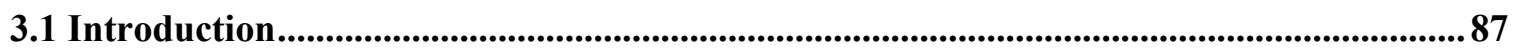

3.2 Methods........................................................................................................................................... 87

3.3 Naming conventions for structures of the Ptarmigan Fiord area.........................................90

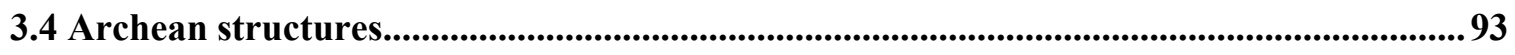

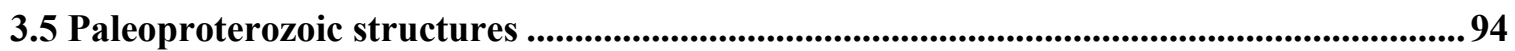

3.5.1 Nature of basement-cover couplets ....................................................................................95

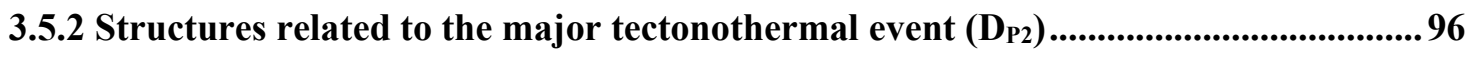

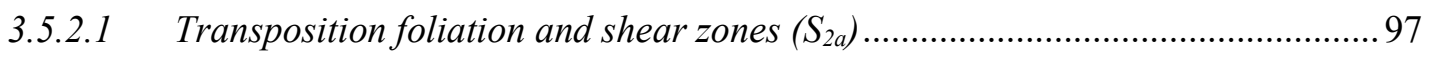

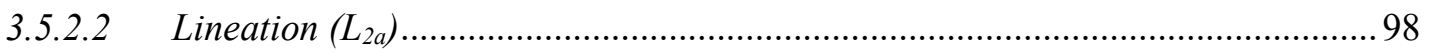




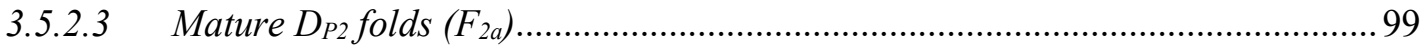

3.5.2.4 Immature $F_{2 b(S E)}$ folds in the southeast domain ............................................ 100

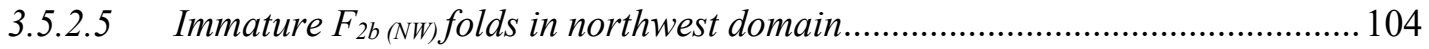

3.5.3 Geometry, description and orientation of post- $D_{\mathrm{P}_{2}}$ structures within all structural

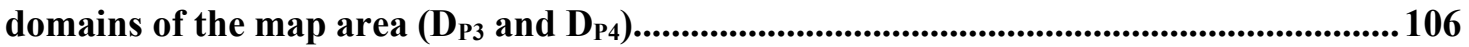

3.5.3.1 Southeast domain $-F_{3 a}$ and $F_{3 b}$ fold generations ......................................... 106

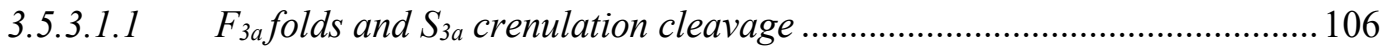

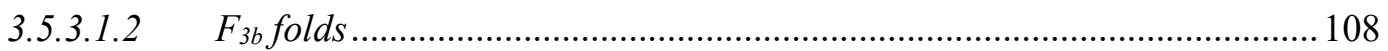

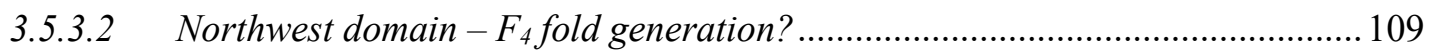

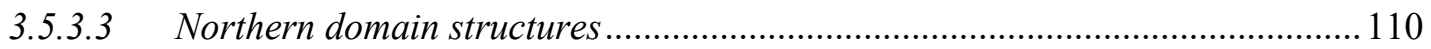

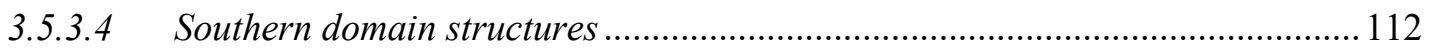

3.6 Domain boundaries - evidence from map pattern \& structures .....................................113

3.7 Structural history of the Ptarmigan Fiord area ..............................................................116

3.8 Preliminary strain and kinematic analysis of Ptarmigan Fiord rocks...........................118

3.8.1 Annealed mylonites and local shear zones within the Ptarmigan Fiord area ......... 119

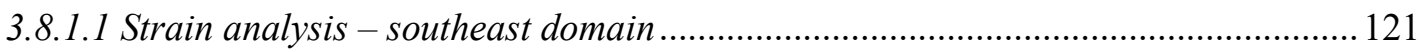

3.8.1.1.1 Strain analyses of basal basement-cover contacts....................................... 121

3.8.1.1.2 Strain analyses within imbricated basement sheets ..................................... 123

3.8.1.1.3 Strain analyses of upper basement contacts ................................................ 124

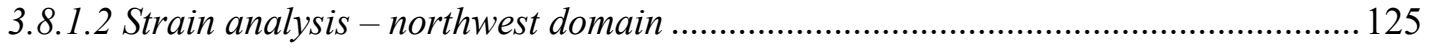

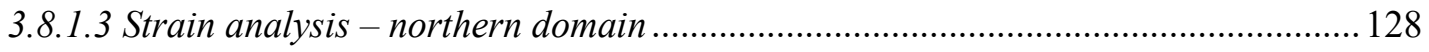

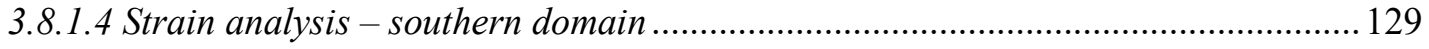

3.8.2 Kinematic indicators in the Ptarmigan Fiord area..................................................130

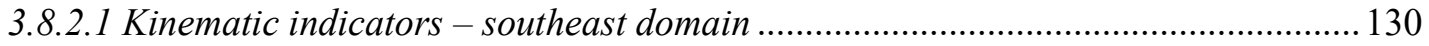

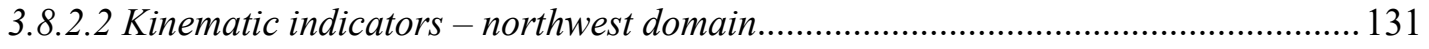


3.8.3 Summary of preliminary strain and kinematic analysis of basement - cover contacts

3.9 Summary and Conclusions 134

CHAPTER 4 - DISCUSSION OF POSSIBLE MODELS FOR TECTONIC EVOLUTION OF THE STUDY AREA, COMPARISON OF STRUCTURAL STYLE AND INFERRED THERMAL REGIMES WITH REGIONAL STUDIES, AND SIGNIFICANCE OF THE FINDINGS FOR TECTONIC EVOLUTION OF THE NORTHERN HALL PENINSULA .....186

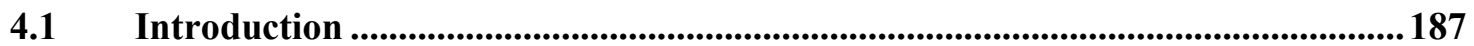

4.2 Integration of thesis results with structural, metamorphic, geochronology, and thermochronology studies in the region

4.2.1 Comparison of structures in the study area and northern Hall Peninsula 188

4.2.2 Integrating results of metamorphic and geochronology studies in the northern Hall

Peninsula with the Ptarmigan Fiord area.

4.3 Structural style of basement-cover imbrications and implications for structural level

4.3.1 Basement-cover imbrication by ductile thrusting

4.3.2 Basement-cover imbrication by pre- $\mathrm{D}_{\mathrm{P} 2}$ brittle thrusting.

4.3.3 Basement-cover imbrication by nappes and mid-crustal flow

4.3.4 Favoured model(s) for basement-cover imbrication

4.4 Extent of Paleoproterozoic deformation in basement?

4.5 Significance of the $T_{3 c}$ domain boundary between the northwest and southeast

domains.

4.6 Significance of the study for the tectonic evolution of the northern Hall Peninsula and the Trans Hudson Orogen 202

CHAPTER 5 - SUMMARY OF CONCLUSIONS AND FUTURE WORK 206

5.1 Summary of Conclusions 207

5.2 Future work. 212

REFERENCES 214 
APPENDIX A- ESTIMATING THE STRIKE AND DIP OF CONTACTS USING

STRUCTURE CONTOURS..................................................................................................227

APPENDIX B- STEREONET ANALYSIS OF POLYPHASE FOLDS (USING DATA FROM

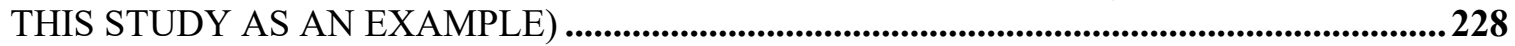

APPENDIX C- STATISTICAL ANALYSIS USED IN STEREONET 9.5 ...............................231

\section{LIST OF APPENDICES}

Appendix A Estimating the strike and dip of contacts using structure contours ...................227

Appendix B Stereonet analysis of polyphase folds.........................................................228

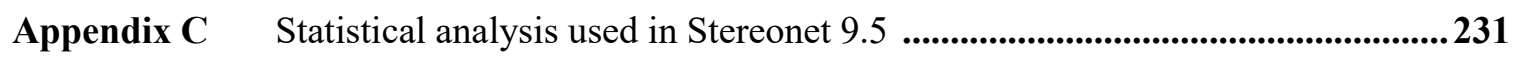




\section{LIST OF TABLES}

Table 1.1 Summary of deformation events from metamorphic rocks on Hall Peninsula .........23

Table 2.1 Comparison of basement units of the Ptarmigan Fiord area and the From et al. (2014) study area Island .................................................................................................................85

Table 3.1 Summary of structures and infered thermal regimes in the Ptarmigan Fiord area .185

Table 4.1 Comparison of structural style and inferred thermal regimes of the Ptarmigan Fiord area and the Skipton et al. (2016) regional study...........................................................................205 


\section{LIST OF FIGURES}

Figure 1.1 Map of North America showing extent of THO.............................................19

Figure 1.2 Simplified geological map of the Quebec-Baffin segment of the THO ..........21

Figure 2.1 Generalized stratigraphic section of Ptarmigan Fiord geology ........................55

Figure 2.2 Panoramic photographs of the Ptarmigan Fiord geology .................................57

Figure 2.3 Outcrop and sample photographs of basement granodiorite ..........................59

Figure 2.4 Outcrop photographs of basement monzogranite .........................................61

Figure 2.5 Sample photograph and photomicrograph of basement monzogranite .........63

Figure 2.6 Outcrop and hand specimen photographs of basement tonalite .....................65

Figure 2.7 Photographs and photomicrographs of basement quartz-diorite ...................67

Figure 2.8 Photographs and photomicrographs of quartzite in cover rocks ....................69

Figure 2.9 Photographs and photomicrographs of psammitic schist interlayered pelitic

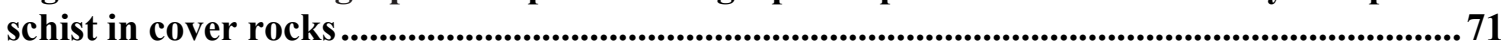

Figure 2.10 Photographs and photomicrograph of pelitic schist in cover rocks .................73

Figure 2.11 Sample photographs and photomicrograph of psammitic schist in cover rocks

Figure 2.12 Outcrop photographs and photomicrograph of amphibolite in cover rocks .77

Figure 2.13 Thin section photomicrographs of amphibolite in cover rocks .........................79

Figure 2.14 Outcrop photographs and photomicrograph of calc-silicate in cover rocks .. 81

Figure 2.15 Outcrop and sample photographs of syenogranite .83

Figure 3.1 Theoretical models illustrating structural relationships in study area......... 137

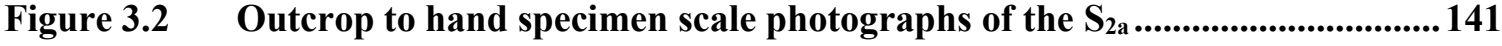

Figure 3.3 Outcrop-scale photographs of the $L_{2 \mathrm{a}}$ and mature folds ................................ 143

Figure 3.4 Stereogram map of lineation data .....................................................................145

Figure 3.5 Outcrop-scale photographs of sheath fold and $F_{2 b(S E)}$ folds............................147

Figure 3.6 Stereogram map of analysis of map-scale $F_{2 b}$ (SE) folds ............................. 149

Figure 3.7 Outcrop and cliff side views of $F_{2 b}(\mathrm{Nw})$ folds in the northwest domain .......... 151

Figure 3.8 Stereogram map of analysis of map-scale $F_{2 b}(\mathrm{NW})$ folds ...........................153

Figure 3.9 Stereogram map of analysis of map-scale $F_{3 a}$ folds.................................... 155

Figure 3.10 Outcrop photographs of F3a folds ....................................................................157

Figure 3.11 Stereogram map of analysis of map-scale $F_{3 b}$ folds.................................. 159 
Figure 3.12 Photographs and photomicrographs of northern domain structures......... 161

Figure 3.13 Photographs and photomicrographs of southern domain structures ......... 163

Figure 3.14 Panorama and outcrop photographs of domain boundaries ........................ 165

Figure 3.15 Photomicrographs of mineral grain boundary textures in thin sections .... 167

Figure 3.15c Photomicrographs of mineral grain boundary textures in thin sections .... 169

Figure 3.16 Variations of progressive strain increase in basement monzogranite from the southeast domain............................................................................................................................... 171

Figure 3.17 Photographs and photomicrographs of monzogranite from C055.............. 173

Figure 3.18 Photographs and photomicrographs of monzogranite from C036............... 175

Figure 3.19 Variations of progressive strain increase in upper basement contacts from

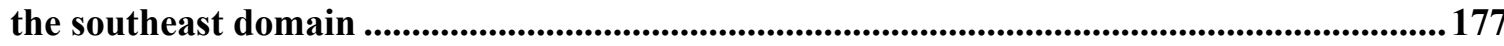

Figure 3.20 Variations of progressive strain increase in basement monzogranite from the northwest domain .........................................................................................................................179

Figure 3.21 Kinematic indicators in basement rocks from the southeast domain ......... 181

Figure 3.22 Kinematic indicator in basement rock from the northwest domain ............183 
CHAPTER 1 - INTRODUCTION TO THE META INCOGNITA MICROCONTINENT AND GEOLOGICAL SETTING OF THE PTARMIGAN FIORD AREA 


\subsection{Introduction}

The study area is located in the Ptarmigan Fiord area, northern Hall Peninsula, south Baffin Island, Nunavut. Ptarmigan Fiord is situated in the Meta Incognita microcontinent (MIM), which comprises Archean crystalline basement and Paleoproterozoic cover rocks, and is a significant cratonic component of the accreted terranes in the Quebec-Baffin segment of the Paleoproterozoic Trans-Hudson orogen (THO, Figure 1.1). The Meta Incognita microcontinent extends across south Baffin Island over a transect length of $\sim 750 \mathrm{~km}$ from Foxe Peninsula in southwest Baffin Island, through Meta Incognita Peninsula on south Baffin Island, and onto Hall Peninsula in southeast Baffin Island (Figure 1.2).

Tectonic models suggest that the Meta Incognita microcontinent was accreted to the Archean Rae craton between ca. 1880-1870 Ma, during the assembly of the Churchill Domain in the upper plate of the Trans-Hudson orogen (Figure 1.1, St-Onge et al., 2007). Timing of regional peak metamorphism and deformation on the Meta Incognita microcontinent is estimated between 1849-1835 Ma (St-Onge et al., 2007) and ca. 1850$1825 \mathrm{Ma}$ (Skipton et al., 2015), occurring in response to the accretion of intra-oceanic arc terranes and cratonic blocks to the southern margin of the microcontinent. Late stage amphibolite- facies metamorphism and localized shear zone development occurred at ca. 1820-1810 Ma (St-Onge et al., 2007). Regional north-south crustal shortening at ca. 1800 Ma (Skipton et al., 2015), overlaps with the ca. 1820-1795 Ma docking of the Superior craton with the Churchill plate, considered to represent the terminal collision of the Trans Hudson orogen (St-Onge et al., 2007, 2009; Corrigan et al., 2009, and references therein). 
The identification of the Meta Incognita microcontinent is the result of regional mapping and thematic studies on southern Baffin Island and the Meta Incognita Peninsula (St-Onge et al., 2000; 2006; 2007, Rayner et al., 2014, and references therein), and Hall Peninsula (Figure A, Map 1; back pocket, Skipton et al., 2015, and references therein). Research by Skipton et al. (2015) focused on the tectonothermal evolution of an obliquely exposed section of the microcontinent on Hall Peninsula (Figure B, Map 1; back pocket), and improved our understanding of the eastern margin of the microcontinent. Complex basement-cover relationships were identified in Ptarmigan Fiord area (Figure B, Map 1; back pocket, Steenkamp and St-Onge, 2014) during regional mapping of northern Hall Peninsula, but the nature of this deformation is not constrained.

The purpose of this field-based thesis is to document the structural style and deformation history of the Ptarmigan Fiord area (Map 1; back pocket), and to assess how it might further constrain the tectonic evolution of Hall Peninsula and the Quebec-Baffin segment of the Trans Hudson orogen. The broad objectives are to:

i) Define and characterize the bedrock map units that outcrop in the Ptarmigan Fiord area;

ii) Compile a new geological map of Ptarmigan Fiord;

iii) Examine potential tectonostratigraphic correlations between the Ptarmigan Fiord area and previously documented cover units of northern Hall Peninsula;

iv) Characterize the geometry, kinematics and timing of polyphase deformation in 
the Ptarmigan Fiord area; and

v) Explore the significance of the documented structural elements of the thesis area with respect to the geology of northern Hall Peninsula in the QuebecBaffin segment of the Trans-Hudson orogen.

To achieve the stated objectives, field data were collected by two to three mapping crews, consisting of two geologists per crew, during seven days of bedrock mapping and sampling at 1:40 000 scale over $\sim 190 \mathrm{~km}^{-2}$ of the Ptarmigan Fiord area during the 2015 field season. The fieldwork was conducted out of a remote field camp located on the McKeand River (Figure A, Map 1; back pocket); 18 helicopter supported ground traverses resulted in 343 geological field stations. These field observations led to the characterization of six map units. Thin section petrography of samples from each map unit refined rock descriptions. Correlations between rocks of the Ptarmigan Fiord area and previously documented rock types of the northern Hall Peninsula were achieved through literature research and consulting published geological maps (Canadian Geoscience Map 262E, 270, Chapter 2).

In order to characterize the geometry and kinematics of polyphase deformation in the study area, detailed structural, microstructural and kinematic studies of samples and field data were conducted. Stereonet analyses of field structural measurements were conducted to assess the orientation and geometry of map-scale folds. Structural cross sections and diagrammatic block models (Figures D, E, and H, Map 1; back pocket) were constructed perpendicular to map-scale structures in order to visually represent the structures in two and three dimensions, respectively. See Chapter 3 for further details on 
geological map compilation and structural analyses.

Map- and regional-scale structural analyses were enabled by comparisons of the structural style of the Ptarmigan Fiord area to similar domains in other orogenic couplets such as the Himalayan-Tibetan orogen in Asia, the Cordillera in western Canada, and the Moine thrust zone in Scotland. Absolute timing of deformation and metamorphism in the study area is extrapolated from previous geochronological studies (Scott, 1999; Rayner, 2014; Skipton et al., 2016), and U-Pb zircon dating of a syenogranite that cross-cuts gneissic foliation in basement of the western part of the map area (Station C117, Map 2; back pocket) by N. Rayner (unpublished data, 12 December 2016). Finally, new tectonic models are proposed for the study area, and their significance for the tectonic evolution of northern Hall Peninsula is discussed (Chapter 4).

\subsection{Tectonic and geologic setting}

\subsubsection{Paleoproterozoic Trans-Hudson orogen}

The Paleoproterozoic Trans-Hudson orogen (THO), as defined by Hoffman (1988) and Lewry and Collerson (1990), is one of the largest and most completely preserved orogenic couplets that formed as a result of the amalgamation of supercontinent Nuna (also known as Columbia) during the period between ca. 2.0 and 1.8 Ga (Rogers and Santosh, 2002). The southwest - northeast striking THO extends at surface and in the subsurface for $>3000 \mathrm{~km}$, from the present-day location of South Dakota, across the Canadian Prairies, Hudson Bay, Baffin Island, Greenland and into Scandinavia (Figure 1.1; Hoffman, 1988). The THO is truncated on both ends by younger 
orogens, and therefore may have originally been more extensive compared to its current configuration (Corrigan, 2012). The THO marks the site of closure of the Manikewan Ocean (Stauffer, 1984), an oceanic plate that is believed to have separated the Superior craton and the composite Churchill domain (Corrigan et al., 2009; Eaton and Darbyshire, 2010). The THO is a composite orogen that contains juvenile to partly contaminated oceanic arc terranes, oceanic crust, ribbon microcontinents and Archean crustal fragments, that were accreted to the upper plate Churchill domain prior to terminal collision with the lower plate Superior craton (Corrigan et al., 2009). Juvenile crust formation, and its accretion to the upper plate Churchill domain is associated with the closure of the Manikewan Ocean (Gibb and Walcott, 1971; St-Onge et al., 2009).

The THO is one of the oldest documented orogens whose evolution follows a complete Wilson Cycle (Corrigan et al., 2009). The history of the THO spans $\sim 150 \mathrm{Ma}$, from the opening of the Manikewan Ocean, at ca. 2.07 to $1.92 \mathrm{Ga}$, to its demise during the final phase of growth of the supercontinent Nuna in the interval from 1.92 to $1.80 \mathrm{Ga}$ (Corrigan et al., 2009).

The architecture of the THO comprises a large core region dominated by juvenile crust of the Reindeer zone, which is bound to the south and north by variably reactivated Archean crust of the Superior craton and Churchill domain, respectively (Figure 1.1). Accretion of juvenile terranes onto the southeast margin of the Rae craton appears to have started at ca. $1.90 \mathrm{Ga}$, and progressed until final closure of the Manikewan Ocean and terminal collision with the Superior craton between ca. 1.83 to $1.79 \mathrm{Ga}$ (Corrigan et al., 2009; St-Onge et al., 2009). The tectonic evolution of the THO is characterized by the development of passive margins, formation of intraoceanic and continental margin arc 
and back-arcs, ophiolite obduction, and collisional thin and thick-skinned thrust imbrication and crustal thickening. In terms of the rate, scale, style and duration of tectonic and crust formation processes, the THO contains most of the important features of modern orogens, such as the Appalachian and Alpine-Himalayan systems, and is considered a prototype for modern accretionary processes (St-Onge et al., 2006, 2009; Corrigan et al., 2009). Given the length and width of the orogen, with its significant crustal thickening and high-grade metamorphism, the THO can be viewed as a large, hot orogen (Beaumont et al., 2006; Corrigan, 2012; Skipton et al., 2016).

\subsubsection{Meta Incognita microcontinent: Quebec-Baffin segment of the Trans Hudson orogen}

The Meta Incognita microcontinent (MIM; Figures $1.1 \& 1.2$ ), which occurs on Hall Peninsula and most of south Baffin Island, is believed to have been accreted to the margin of the Rae craton between ca. 1883 and $1885 \mathrm{Ma}$ (St-Onge et al., 2006). The Meta Incognita microcontinent consists of an Archean orthogneiss basement complex that is overlain by Paleoproterozoic clastic and chemical metasedimentary rocks with interlayered amphibolite (interpreted as a metamorphosed clastic-carbonate-shelf succession known as the Lake Harbour Group). Both the basement and cover were intruded by ca. 1865 - 1848 Ma quartz-diorite to monzogranite plutons of the Cumberland batholith (Scott and Wodicka, 1998). Basement of the Meta Incognita microcontinent is correlated with the ca. 3020-2780 Ma crystalline basement of the Superior craton (Figure 1.2; St-Onge et al., 2000). 
Alternative tectonic links have been proposed for the Meta Incognita microcontinent and Hall Peninsula basement rocks in the literature, including the Rae craton, Superior craton, North Atlantic craton, the Core Zone in northern Labrador, the Aasiaat domain in Western Greenland, and/or a distinct cratonic parentage (Jackson et al., 1990; Scott, 1999; St-Onge et al., 2009; and references therein). A number of proposed sutures appear to converge on southern Baffin Island, when projected from the mainland in Canada or Greenland (Figure 1.2; St-Onge et al., 2009), including the east west striking Baffin suture, the east - west striking Nagssugtoqidian and Disco Bugt sutures, and the northwest-striking Tasiuyak gneiss (Corrigan et al., 2009; St-Onge et al., 2009; and references therein).

The Meta Incognita microcontinent experienced granulite-facies metamorphism and deformation at ca. $1849-1835 \mathrm{Ma}$, which is interpreted as a consequence of the accretion of the Narsajuaq arc (Figure 1.2) at ca. $1845 \mathrm{Ma}$, and emplacement of the Cumberland batholith at ca. 1865 - 1848 Ma (St-Onge et al., 2007). Alternately, metamorphism and deformation may have been caused by the subduction of Archean crystalline Sugluk block beneath the Meta Incognita microcontinent along the Big Island Suture (Figure 1.2; Corrigan et al., 2009; Whalen et al., 2010).

\subsubsection{Geology of Hall Peninsula}

\subsubsection{Previous mapping and geoscience studies}

Reconnaissance bedrock mapping of Hall Peninsula was first conducted by the Geological Survey of Canada during 'Operation Amadjuak' (1:506 880 scale; Blackadar, 1967). More detailed mapping and geochronological studies were conducted by Scott 
$(1996,1999)$ at 1:40 000 scale and 1:200 000 scale (respectively), and bedrock mapping of the Chidliak kimberlite field was conducted by Ansdell et al. (2012) at a scale of 1:25 000. Regional bedrock mapping of Hall Peninsula was conducted at 1:100 000 scale by the Canada-Nunavut Geoscience Office (CNGO) during the 2012-2014 Hall Peninsula Integrated Geoscience Program (HPIGP). Results from southern and northern Hall Peninsula are presented in Machado et al. (2013a, b) and Steenkamp and St-Onge (2014), respectively. Thematic studies include-investigations of deformation and metamorphism related to the THO (St-Onge et al., 2002, 2006, 2007; Braden, 2013; Skipton et al., 2013; Dyck and St-Onge, 2014; Skipton and St-Onge, 2014; Chadwick et al., 2015; Skipton et al., 2015, 2016), age of map units in the region (Rayner et al., 2013; Rayner, 2014, 2015), nature of the Archean basement rocks (From et al., 2013, 2014, 2015; Ansdell et al., 2015), tectonostratigraphy of Paleoproterozoic rock types (MacKay et al., 2013; MacKay and Ansdell, 2014), kimberlite emplacement (Nicholas et al., 2013; Pell et al., 2013), Paleozoic rock record (Zhang and Pell, 2013), economic and carving stone potential of pegmatites, layered mafic-ultramafic sills and altered ultramafic bodies (Steenkamp et al., 2014; Bigio and Lentz, 2015; Bigio et al., 2015; Liikane et al., 2015; St-Onge et al., 2015), and Quaternary permafrost and glaciation (Leblanc-Dumas et al., 2013, 2015; Tremblay et al., 2013, 2014, 2015).

\subsubsection{Tectonostratigraphic overview}

The bedrock geology of eastern Hall Peninsula (Figure B, Map 1; back pocket) includes Archean crystalline basement orthogneiss with crystallization ages that range between ca. 3209 and $2682 \mathrm{Ma}$ (Scott, 1999; Rayner, 2014, 2015; Steenkamp and St- 
Onge, 2014, From et al., 2015). The basement orthogneiss comprises dominantly gneissic and migmatitic tonalite to monzogranite with local pods of amphibolite (gold coloured unit, Figure B, Map 1; back pocket; From et al., 2014; Steenkamp and St-Onge, 2014). The basement rocks are nonconformably overlain by middle Paleoproterozoic cover rocks with thicknesses that vary between $10 \mathrm{~m}$ and $10 \mathrm{~km}$ (brown unit, Figure B, Map 1; back pocket; Steenkamp and St-Onge, 2014).

In the eastern part of the peninsula, the cover rocks consist of upper-amphibolite to lower-granulite facies quartzofeldspathic and pelitic migmatitic schist and gneiss, and amphibolite, calc-silicate and meta-ironstones (Steenkamp and St-Onge, 2014). The base of the package comprises a blue-grey quartzite, which is overlain by a rusty brownweathering unit of alternating psammitic, semipelitic and pelitic metasedimentary rocks. Above the clastic metasedimentary units, lies a layered sequence of semipelitic schist, calc-silicate, meta-ironstone and amphibolite. The amphibolite is interpreted as metamorphosed volcaniclastic rock with minor subaerial mafic volcanic flows, on the basis of whole-rock major- and trace-element geochemistry of amphibolite samples (MacKay et al., 2013; MacKay and Ansdell, 2014; Steenkamp and St-Onge, 2014). The cover rocks have an estimated maximum depositional age of ca. $1960 \mathrm{Ma}$ on the basis of $\mathrm{U}-\mathrm{Pb}$ zircon geochronology of cover rocks from the eastern part of Hall Peninsula (Rayner, 2014, 2015).

The western part of the peninsula consists of Paleoproterozoic cover and plutonic intrusive rocks; Archean basement is not exposed at the surface (Figure B, Map 1; back pocket; Steenkamp and St-Onge, 2014). The western peninsula cover rocks are dominantly pelitic and psammitic metasedimentary units, which have maximum 
depositional ages of ca. $2100-1906 \mathrm{Ma}$, on the basis of $\mathrm{U}-\mathrm{Pb}$ zircon geochronology of cover rocks from the western part of Hall Peninsula (Rayner, 2014, 2015).

The protolith of metasedimentary rocks of the eastern part of Hall peninsula are interpreted as margin-proximal sediments based on quartzofeldspathic and psammiticpelitic compositions, whereas the protolith of metasedimentary rocks of the western part of Hall Peninsula are interpreted as deep-water, distal sediments based on the dominantly pelitic composition. The transition from margin-proximal cover units, in the east, to mostly deep-water, distal units, in the west, has been interpreted as a progressive change in paleodepositional environment (Steenkamp and St-Onge, 2014).

Garnet-bearing leucogranite dykes and sills, up to $\sim 100 \mathrm{~m}$ thick, occur throughout the peninsula, and are interpreted as segregated melt related to pre- to synthermal-peak metamorphism (Dyck and St-Onge, 2014). The crystallization age of one of the leucogranites is $1867 \pm 8 \mathrm{Ma}$ (U-Pb zircon; Rayner, 2014). Orthopyroxene-bearing tonalite to quartz diorite (red unit; Figure B, Map 1; back pocket), intrude the cover rocks on the western part of the peninsula (Steenkamp and St-Onge, 2014). The composition of the intrusions ranges from biotite-orthopyroxene \pm magnetite \pm clinopyroxene \pm garnetbearing tonalite to quartz diorite. Several orthopyroxene-bearing intrusions yield emplacement ages between ca. 1890 Ma and ca. 1852 Ma (Scott, 1999; Rayner, 2014, 2015). Some of the intrusions are believed to be of igneous origin based on the presence of euhedral orthopyroxene phenocrysts, and/or euhedral K-feldspar megacrysts. However, the bulk of the intrusions contain subhedral to anhedral orthopyroxene, aligned with the regional metamorphic foliation, suggesting an anatectic origin (Skipton et al., 2016). 


\subsubsection{Archean metamorphism and deformation}

The Archean basement of Hall Peninsula records a complex and protracted deformation and metamorphic history, starting in the Archean and ending in the Paleoproterozoic. Mapping at 1:6000 scale of a section of basement by From et al. (2014) outlines a minimum of eight rock types, which have compositions ranging from tonalite to granodiorite; the respective age of each rock type is ordered using cross-cutting relationships. Zircon $\mathrm{U}-\mathrm{Pb}$ geochronology was conducted on six of these basement rock types resulting in isotopic ages ranging between ca. 3209 to $2682 \mathrm{Ma}$, supporting a protracted period of Archean magmatic activity (From et al., 2015). More details about the Archean basement history will be presented in Chapter 2, Section 2.4.1. The Archean basement was later involved in regional Paleoproterozoic deformation and metamorphism, as evidenced by basement-involved thrusting and folding of the Paleoproterozoic cover units (Section 1.2.3.5, this thesis; Steenkamp and St-Onge, 2014; Skipton et al., 2016).

\subsubsection{Paleoproterozoic metamorphism}

The metamorphic grade of rocks on Hall Peninsula increases from east to west, with three principal north-south trending metamorphic mineral zones recognized on the basis of pelitic mineral assemblages (Figure B, Map 1; back pocket; Skipton et al., 2016). The eastern metamorphic zone is characterized by mid-amphibolite facies metamorphic mineral assemblages comprising biotite + muscovite \pm garnet \pm sillimanite \pm K-feldspar with quartzofeldspathic veins (Figure B, Map 1; back pocket; Skipton et al., 2016). The 
coarse-grained quartzofeldspathic veins $(<15 \mathrm{vol} \%)$, composed of quartz, plagioclase, and \pm K-feldspar, have been interpreted as leucosome formed from in-situ melt. The abundance of both leucosome and sillimanite decreases towards the east, whereas muscovite aligned within the metamorphic foliation becomes more abundant (Skipton et al., 2016). A penetrative foliation is defined by the alignment of biotite, \pm muscovite, sillimanite, and quartzofeldspathic veins. Sillimanite is typically fine-grained and occurs as fine-grained fibrolite within faserkiesel clots.

The central metamorphic zone comprises upper amphibolite-facies metamorphic mineral assemblages of biotite + garnet + sillimanite + K-feldspar + quartzofeldspathic veins, and muscovite is absent (Figure B, Map 1; back pocket; Skipton et al., 2016). Sillimanite occurring within faserkiesel clots is typically coarse-grained in the central metamorphic zone. The abundance of quartzofeldspathic veins increases to an estimated $\sim 10-20 \mathrm{vol} \%$, and is interpreted as leucosome formed from in-situ melt (Skipton et al., 2016).

The western metamorphic zone contains granulite-facies metamorphic mineral assemblages of garnet + sillimanite $+\mathrm{K}$-feldspar with quartzofeldspathic veins and \pm cordierite \pm orthopyroxene \pm biotite (Figure B, Map 1; back pocket; Skipton et al., 2016). Sillimanite is coarse-grained, and the quartzofeldspathic veins, interpreted as leucosome formed from in-situ melt, typically comprise $\geq 15 \mathrm{vol} \%$. Alternating garnet- and sillimanite-rich compositional bands, leucosome, and mineral orientation define the foliation. Leucogranite dykes and sills, interpreted as segregated melt (Dyck and StOnge, 2014), are aligned parallel to the foliation and contain garnet \pm biotite \pm cordierite. 
The metamorphic grade increases from mid-amphibolite facies in the east to granulite facies in the west of Hall Peninsula. The volume of leucogranite dykes and sills, interpreted as in-situ melt, increases from east to west and likely formed by the dehydration and breakdown of muscovite and biotite in pelitic and semipelitic cover protoliths (Dyck and St-Onge, 2014; and references therein).

\subsubsection{Paleoproterozoic structural history}

For the purpose of this regional summary of Hall Peninsula structures, the discussion will be restricted to Paleoproterozoic structures and excludes the Archean structures. Three regional Paleoproterozoic deformation events have been proposed by Steenkamp and St-Onge (2014) and Skipton et al. (2016) for rocks of the Hall Peninsula (Table 1.1), and include: east directed thin-skinned shortening (involving only cover; $\mathrm{D}_{1}$ ), east directed thick-skinned shortening (involving both basement and cover; $\mathrm{D}_{2}$ ), and north-south directed thick-skinned shortening $\left(\mathrm{D}_{3}\right)$.

The oldest regional structures related to $\mathrm{D}_{1}$ are east- to northeast verging isoclinal folds $\left(\mathrm{F}_{1 \mathrm{a}}\right)$ that fold bedding $\left(\mathrm{S}_{0}\right)$ and have axial surfaces parallel to a moderately southwest- to west-dipping regional penetrative foliation $\left(\mathrm{S}_{1 \mathrm{a}}\right)$ that is defined by metamorphic-peak mineral assemblages. Stretching and mineral lineations $\left(\mathrm{L}_{1 \mathrm{a}}\right)$, defined by elongate faserkiesel clots on the Eastern Hall Peninsula and coarse-grained sillimanite on the western Hall Peninsula, are parallel to the $\mathrm{F}_{1 \mathrm{a}}$ fold axes (Skipton et al., 2016). Locally, these structures have been refolded by east- to northeast-verging, isoclinal-toopen folds $\left(\mathrm{F}_{1 b}\right)$ with an axial planar foliation $\left(\mathrm{S}_{1 b}\right)$ and a mineral growth lineation $\left(\mathrm{L}_{1 b}\right)$ parallel to $F_{1 b}$ fold hinges (Dyck and St-Onge, 2014). The $D_{1 a}$ structures have the same 
orientations as the $\mathrm{D}_{1 \mathrm{~b}}$ structures, and are indistinguishable from each other, without field evidence of fold superposition. Therefore, for simplicity, $\mathrm{S}_{\mathrm{a}}$ and $\mathrm{S}_{\mathrm{bb}}$ are not differentiated, and are both referred to as $\mathrm{S}_{1}$.

Continued east-directed shortening $\left(\mathrm{D}_{2}\right)$, involving basement units, was accommodated by thick-skinned thrust faults $\left(\mathrm{T}_{2}\right)$, which occur on the northern Hall Peninsula as imbricate couplets of Archean basement orthogneiss and Paleoproterozoic cover rocks (Dyck and St-Onge, 2014; Chadwick et al., 2015; Skipton et al., 2016). Grain-size reduction and the presence of mylonitic shear zones, at the base of the basement-cover imbricates, are interpreted as evidence of ductile shearing at the base of the $T_{2}$ thick-skinned thrust fault structures. Thick-skinned, SSE-striking, moderately west-dipping folds $\left(\mathrm{F}_{2}\right)$, observed in cliff faces on northern Hall Peninsula, are also associated with $\mathrm{D}_{2}$ deformation. A west-plunging stretching lineation $\left(\mathrm{L}_{2}\right)$ defined by elongate aggregates of amphibolite-facies minerals and quartz and feldspar rodding, is associated with $T_{2}$ thrust contacts and $F_{2}$ fold limbs. Both $T_{2}$ and $F_{2}$ structures show westover-east kinematics based on outcrop-scale asymmetric porphyroblasts in mylonites and east-verging, asymmetric folds (Skipton et al., 2016).

The final deformation event $\left(\mathrm{D}_{3}\right)$ is manifested as post-thermal-peak basementinvolved folds $\left(\mathrm{F}_{3}\right) . \mathrm{F}_{3}$ folds have west-striking axial planes that dip steeply to the north, wavelengths up to several km's and locally fold $\mathrm{D}_{1}$ and $\mathrm{D}_{2}$ structures (Steenkamp and StOnge, 2014). Cm-to mm-scale crenulations and a west-striking crenulation cleavage $\left(\mathrm{S}_{3}\right)$, that overprint the $S_{1}$ foliation in pelitic cover rocks, are interpreted as being related to F3 (Skipton and St-Onge, 2014). 


\subsection{Geology of the Ptarmigan Fiord area}

Ptarmigan Fiord is located on the northwestern Hall Peninsula (red outline; Figure B, Map 1; back pocket). The $\sim 190 \mathrm{~km}^{-2}$ map area lies in the eastern mid-amphibolite facies metamorphic domain (Figure B, Map 1; back pocket) and the geology is dominated by Neoarchean basement rocks with varying amounts of nonconformably overlying metasedimentary and metavolcanic cover rocks.

There are three principal map units (Map 1; back pocket): 1) Neoarchean orthogneiss basement (gold map unit) composed of multiple phases of variably deformed gneissic to massive tonalite, quartz diorite, granodiorite, monzogranite and syenogranite, 2) Paleoproterozoic Lake Harbour Group cover rocks comprising pelitic to psammitic schist (brown map unit), amphibolite (green map unit), calc-silicate (blue map unit) and quartzite (yellow map unit), and 3) weakly foliated syenogranite intrusions (pink map unit), dated at $1861 \pm 2$ Ma by N. Rayner (unpublished data, 12 December 2016) that crosscut the gneissic foliation within the basement rocks. The metamorphic grade of the study area is mid-amphibolite facies, as defined by the assemblage biotite + muscovite \pm garnet \pm sillimanite $\pm \mathrm{K}$-feldspar \pm quartzofeldspathic vein. Quartzofeldspathic veins are interpreted as leucosome formed by in-situ melt. Detailed descriptions of map units, and interpreted protoliths, are provided in Chapter 2.

The surface map pattern is dominated by folded imbricates of basement and cover units, with variably deformed contacts. The orientation of the basement - cover imbricates is controlled by at least four generations of structures including map-scale 
folds, and cross-cutting ductile faults. The structures and associated deformation mechanism(s) are discussed in detail in Chapter 3 and 4.

There are four structural domains within the study area, termed the southeast, northwest, northern, and southern domains (Figure F and H, Map 1; back pocket), and the main focus of this thesis is on the southeast and northwest domains. The southeast domain consists of sheets of repeated basement and cover occurring in the refolded keel of an upright, close to open, shallowly plunging $\mathrm{F}_{2 b}$ (SE) syncline. The northwest domain, is characterized by a moderately northwest dipping panel of repeated basement and cover rocks. The boundary between the southeast and northwest domains is a ductile shear zone. The northern and southern domains are predominantly basement terranes with minor couplets of cover rocks, and the nature of the domain boundaries is uncertain. 
Figure 1.1 Simplified geological map of North America showing the regional extent of the Trans-Hudson orogen (outlined in red), and the positions of the upper-plate Churchill domain and lower-plate Superior craton. The location of the Meta Incognita microcontinent (MIM), underlying Hall Peninsula, is outlined in white. Modified after StOnge et al. (2006) and Skipton et al. (2016). 


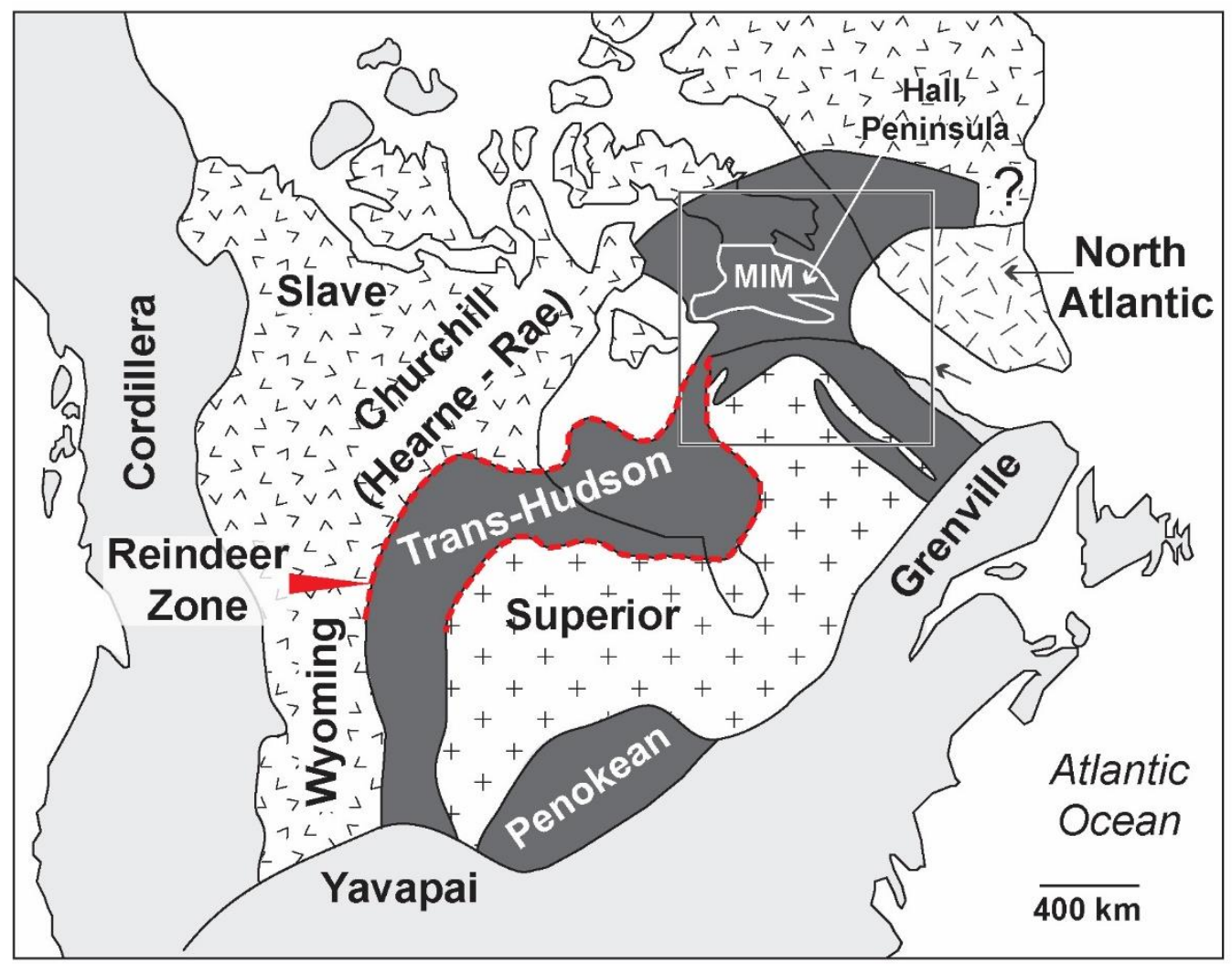

1.92-1.80 Ga orogens $\vec{r} \vec{r}$ Archean-Proterozoic Churchill domain (Trans-Hudson Orogen upper-plate)

Post-1.80 Ga orogens t+ Archean Superior craton and cover (Trans-Hudson orogen lower-plate)

I-1 Archean North Atlantic craton 
Figure 1.2 Simplified geological map of the Quebec-Baffin segment of the TransHudson orogen, showing the Archean cratons, main lithological units, and the location of crustal sutures proposed by previous workers. Hall Peninsula, the area covered in Figure B, Map 1; back pocket, is outlined in black, and the approximate location of the study area is shown with a red star. Modified after St-Onge et al. (2009) and Skipton et al. (2016). 


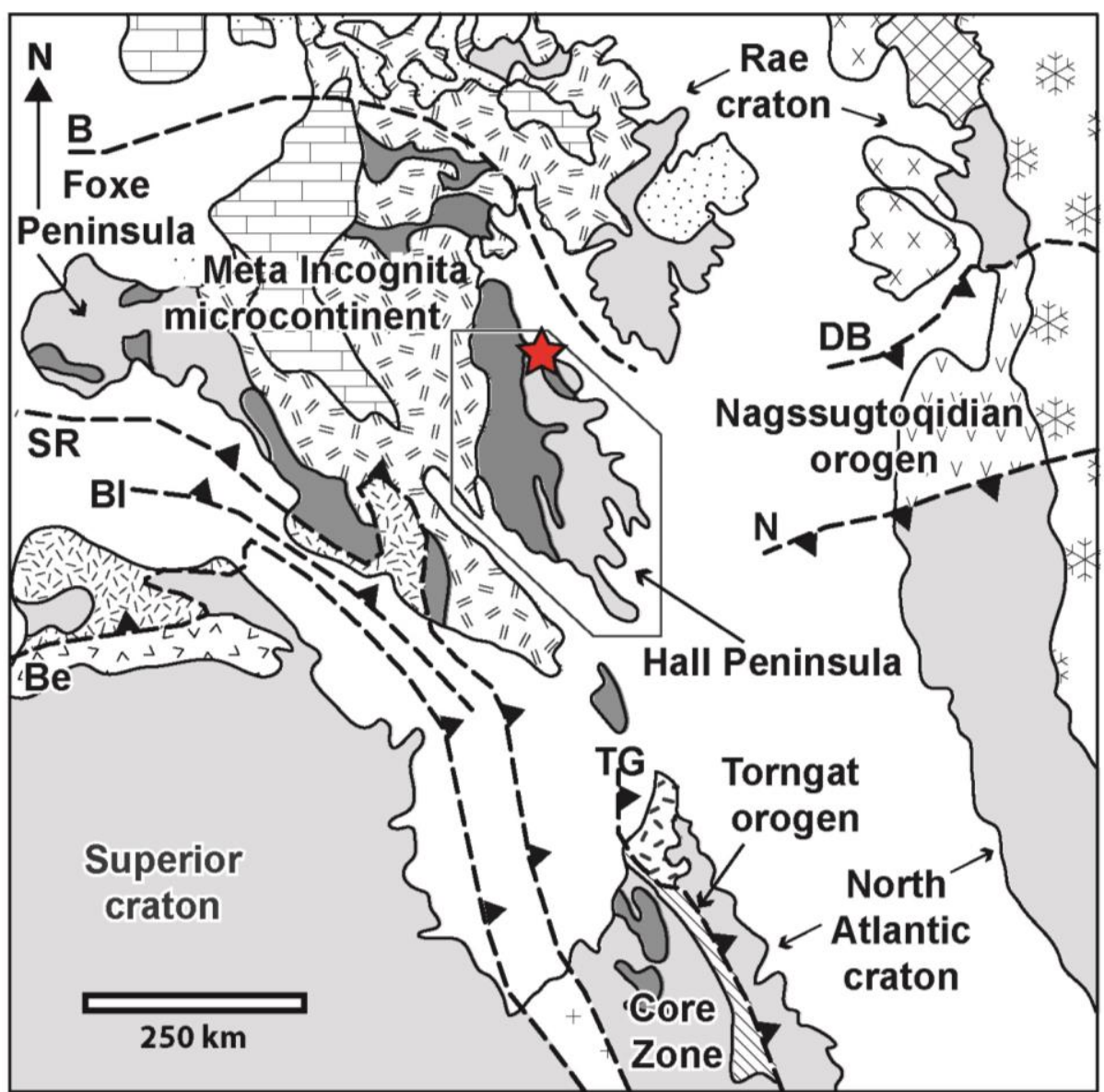

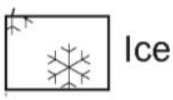

$x \times \frac{\text { Paleogene magmatic }}{\text { province }}$

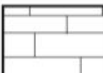

Phanerozoic cover

$++\begin{aligned} & \text { De Pas batholith } \\ & (1.83-1.81 \mathrm{Ga})\end{aligned}$

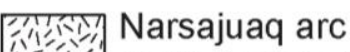

(1.86-1.82 Ga)

${ }^{\prime \prime} " 1 "$ " C Cumberland batholith

"I $==$ (1.86-1.85 Ga)

$\because \because=1$ Burwell arc

泣消 (1.91-1.87 Ga)

Tasiuyak paragneiss
$(1.94 \mathrm{Ga})$

$\wedge\lrcorner$ Povungnituk and

$(>1.99-1.92 \mathrm{Ga})$
Karrat and Anap nunâ groups $(2.15-1.89 \mathrm{Ga})$

Piling/Hoare Bay groups (2.16-1.90 Ga)

Lake Harbour Group

(2.20-1.90 Ga)

$\vee \vee \vee$

Aasiaat domain

(2.87-1.89 Ga)

$>2.0 \mathrm{Ga}$ cratonic blocks

Crustal Sutures

Be: Bergeron (1.82-1.795 Ga)

SR: Soper River (1.845 Ga)

$\mathrm{N}$ : Nagssugtoqidian (1.86-1.84 Ga)

BI: Big Island (1.865-1.85 Ga)

TG: Tasiuyak gneiss (1.87-1.85 Ga)

B: Baffin (1.88-1.865 Ga)

DB: Disco Bugt (1.88 Ga) 
Table 1.1 Summary of structures and related deformation events from metamorphosed basement, cover, and intrusive rocks on Hall Peninsula, Baffin Island (from Skipton et al., 2016). 


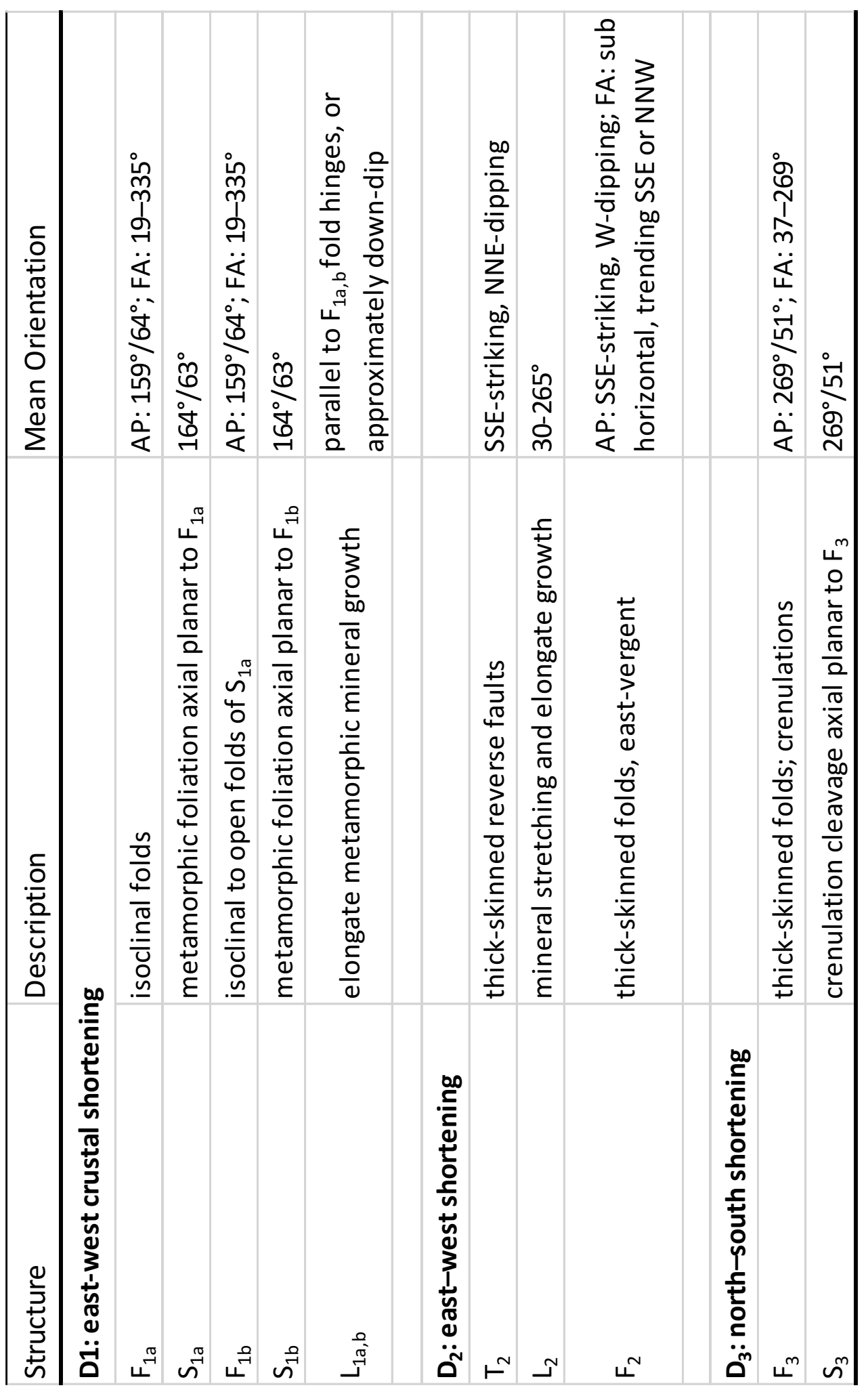


CHAPTER 2 - GEOLOGY OF THE PTARMIGAN FIORD AREA, NORTHERN HALL PENINSULA, NUNAVUT 


\subsection{Introduction}

The purpose of this chapter is to describe map units of the Ptarmigan Fiord area, their constituent rock types, and their tectonostratigraphic relationships. The protolith of each rock type is interpreted on the basis of mineral assemblages and textures at the outcrop and thin section scales. Rock units in the Ptarmigan Fiord area are correlated with known units on the western Hall Peninsula. Preserved tectonostratigraphic relationships within cover units are compared to regional stratigraphic sequences in order to infer the potential depositional environment for the cover rock types.

Rocks of the Ptarmigan Fiord area have experienced penetrative polyphase deformation, which includes at least one high-strain, syn-metamorphic transposition event at amphibolite facies in the presence of leucosome ( $\mathrm{D}_{\mathrm{P} 2}$, Chapter 3, this thesis). Consequently, the unit thicknesses observed in the study area are structural thicknesses and likely do not represent primary sedimentary thickness. There may also be unrecognized structural contacts between units and therefore the generalized lithological column of Figure 2.1 may not represent the original stratigraphic succession. The description of map units is presented from lowest to highest structural levels.

The three map-scale units in the Ptarmigan Fiord area are: 1) Archean orthogneiss basement complex, 2) Paleoproterozoic Lake Harbour Group cover rocks, and 3) Paleoproterozoic plutonic rocks (Map 1, back pocket). The orthogneiss basement complex consists of multiple rock types: felsic rocks range in composition from tonalite to monzogranite, and mafic rocks range from quartz-diorite to gabbro. The foliated to gneissic metaplutonic basement rocks are locally cross-cut by $\mathrm{cm}$ to $\mathrm{m}$-thick felsic 
granitic veins, which are themselves folded and variably deformed. Light greyweathering orthogneiss basement complex lies in sharp contact with rusty brownweathering metasedimentary and dark grey-weathering metavolcanic rocks of the Lake Harbour Group. Basement and supracrustal rocks are differentiated by general physical aspect, composition, and weathering characteristics, as shown in the panoramic photographs (Figure 2.2a \& b).

The Paleoproterozoic Lake Harbour Group cover units include metasedimentary rocks that range in composition from migmatitic psammitic, semipelitic and pelitic schist, to calc-silicate and quartzite. The metasedimentary rock types are interlayered with garnet-bearing amphibolite. Although the cover units are deformed and have likely been structurally thinned, they occur in a fairly systematic order. A representation of the generalized tectonostratigraphy is shown in Figure 2.1 and a supporting annotated cliff face photograph (Figure 2.2a). Within the gneissic basement complex, $\sim 2 \mathrm{~km} \mathrm{WNW}$ of Amittuq Lake, a third map-scale unit consists of a weakly foliated, medium-grained biotite syenogranite (Unit 6, Figure 2.1), which cross-cut the gneissic foliation of the basement complex rocks.

Plutonic rock names were assigned using the QAPF classification diagram devised by Streckeisen (1974). The modal abundance of quartz (Q), alkali feldspar (A), and plagioclase $(\mathrm{P})$ were estimated for representative samples of each basement rock type both in the field and using thin section petrography. Estimated mineral volumes in basement and cover rocks are reported as volume percent (\%). Rock name modifiers for metaigneous basement rocks are based on the convention proposed by Le Maitre (1989, 2002) for ordering minerals in the rock name according to abundance; the most abundant 
mineral is stated first and the least abundant mineral is stated last. Rock name modifiers for metamorphic cover rocks are based on the convention used by the Geological Survey of Canada for ordering minerals in the rock name according to abundance; the most abundant (or significant) mineral is stated first. Although most of the rocks in the Ptarmigan Fiord area are penetratively foliated metamorphic rocks, the prefix 'meta' is omitted from the following descriptions for brevity. Mineral abbreviations used throughout this chapter follow the convention of Whitney and Evans (2010).

\subsection{Map units}

\subsubsection{Archean orthogneissic basement complex (Unit 1)}

The Archean gneissic basement complex (Agn, Map 1; back pocket) consists predominantly of variably deformed hornblende-biotite-orthopyroxene granitoids with varying proportions of these three main accessory minerals. The Archean orthogneiss complex has a minimum structural thickness of $120 \mathrm{~m}$ in the study area (within imbricated panels of basement and cover, Map 1; back pocket). A crystallization age of ca. $2719 \pm 4 \mathrm{Ma}$ (Rayner, 2015) was obtained for a representative sample of K-feldspar porphyritic monzogranite collected from the Ptarmigan Fiord area (see section 2.2.1.2). The orthogneiss basement complex can be broadly divided into four lithological groups, although considerable heterogeneity is characteristic of any single outcrop. Therefore, map units are designated on the basis of predominant rock type.

The most extensive unit in the orthogneiss basement is biotitehornblende \pm orthopyroxene granodiorite (Unit $1 a-A g d$ ), that typically consists of layered 
and veined granodiorite with varying proportions of hornblende and biotite, and is interpreted to have been derived from igneous plutonic rocks.

The granodiorite encloses mappable lenses and layers of up to $\sim 1 \mathrm{~km}^{-2}$ in area of veined biotite-hornblende monzogranite (Unit $1 b-A m z)$. The monzogranite has variable proportions of biotite and hornblende, and locally contains cm-long alkali-feldspar porphyroclasts or megacrysts. It locally encloses quartz-diorite to gabbro pods and enclaves.

In the western and southwestern part of the map area, the granodiorite encloses mappable layers and masses of up to $\sim 2 \mathrm{~km}^{-2}$ area of gneissic biotite-hornblendemuscovite tonalite (Unit $1 c-A t)$. The tonalite is typically interlayered with $\mathrm{cm}$ - to $\mathrm{m}$ thick blocky bands and enclaves of hornblende-biotite quartz-diorite to gabbro (Unit 1d$A q d$ ). The dioritic to gabbroic rocks also occur as $\mathrm{cm}$ - to m-thick blocky to elongate enclaves and pods within the granodiorite and monzogranite.

\subsubsection{Unit 1a: biotite-hornblende \pm orthopyroxene granodiorite}

The biotite-hornblende \pm orthopyroxene granodiorite, veined with granitic material, is the most extensive granitoid within the orthogneiss basement complex and is exposed in varying amounts across the entire $190 \mathrm{~km}^{-2}$ study area. It is the dominant rock unit in larger 1 to $3 \mathrm{~km}^{-2}$ areas within the 'B0' autochthonous basement in the southern half of the map area, and in smaller 1 to $150 \mathrm{~km}^{-2}$ areas in the repeated basement slices 'B1' to 'B6' in the center and to the northwest of the map area (Map 1, back pocket). The granodiorite has a minimum thickness of $100 \mathrm{~m}$, has been traced $\sim 3 \mathrm{~km}$ along strike, and outcrops typically weather as resistive blocky knolls and glaciated pavement surfaces. 
The granodiorite unit varies significantly throughout the study area. Relatively homogeneous outcrops consisting of light grey-weathering, medium-grained, biotitehornblende granodiorite veined with white quartzofeldspathic material (Figure 2.3a), are exposed in the 'B0' autochthonous basement at station C037 (Map 2, back pocket). At station C091 (Map 2, back pocket), $2.8 \mathrm{~km}$ north-northeast of the center of Amittuq Lake, the medium-grained granodiorite exhibits contrasting compositional layering on a scale of a $1-5 \mathrm{~cm}$, determined by the varying amount of hornblende and biotite in the layers (Figure 2.3b). Approximately $230 \mathrm{~m}$ southeast of station C091, the light grey-weathering granodiorite is interlayered with other rock types such as quartz-diorite and syenogranite pegmatite, on a scale of $1-20 \mathrm{~cm}$ (Station C090, Figure 2.3c).

In hand specimen, granodiorite is light grey-weathering, typically fine-to medium-grained, weakly foliated to gneissic, and has a light grey flecked salt and pepper colour on the fresh surface. In higher strained samples, lenticular arrangement of mineral aggregates and flattened feldspar phenocrysts define a strong foliation (Figure 2.3d). Aggregates of medium-grained quartz and feldspar range up to $2 \mathrm{~cm}$ or more thick, whereas fine-grained hornblende and biotite form generally continuous linear aggregates or clots ranging up to $1 \mathrm{~cm}$ in thickness. In some areas, coarse single porphyroblasts of hornblende define a stretching lineation. Alkali feldspar present in the granodiorite, occurs typically as porphyroclasts and range from 0.25 to $1 \mathrm{~cm}$ in length, and comprises up to $10 \%$ of the rock.

Quartz forms thin lenticles of compound grains, and higher strained equivalents form relic quartz ribbon textures composed of annealed grains. Biotite is generally 
predominant over hornblende, composing up to $20 \%$ versus $5 \%$, and occurs commonly with hornblende as 'clotty' aggregates or linear aggregates described above.

The predominant vein material consists of medium-grained, biotite-bearing, quartzofeldspathic material, interpreted as leucosome that formed from in-situ melting. These $1-20 \mathrm{~cm}$ thick veins are generally concordant with the dominant foliation (Figure 2.3a).

\subsubsection{Unit 1b: biotite-hornblende monzogranite}

The biotite-hornblende monzogranite unit predominantly occurs as $\sim 1 \mathrm{~km}^{-2}$ mappable lenses, as well as smaller masses and lenses (e.g. $\sim 400 \mathrm{~m}^{-2}$ ) distributed randomly within the dominant granodiorite unit. The biotite-hornblende monzogranite is exposed throughout the study area in both the autochthonous basement 'B0' and the repeated basement slices 'B1' to 'B7' (Map 1; back pocket). The biotite-hornblende monzogranite has a minimum thickness of $80-100 \mathrm{~m}$, has been traced $\sim 1 \mathrm{~km}$ along strike, and outcrops typically weather as rounded blocky masses and glacial pavement surfaces in lower strained zones (Figure 2.4a). Outcrops in or near high strain contacts between basement - cover couplets tend to weather in recessive and resistant layers, on a scale of $10 \mathrm{~cm}$ or more, controlled by the foliation. Contacts of the biotite-hornblende monzogranite with other units are sharp, but often irregular. A sample of K-feldspar porphyritic monzogranite collected from the southeastern part of Ptarmigan Fiord (R003, Map 2; back pocket), yielded a zircon U-Pb crystallization age of $2719 \pm 4 \mathrm{Ma}$ (Rayner, 2015). 
In outcrop, the monzogranite unit in the autochthonous basement unit 'B0' consists predominantly of a reddish-grey to light brown-weathering, medium to coarsegrained, inequigranular biotite-hornblende monzogranite with $0.5-2 \mathrm{~cm}$ elongate and rounded alkali-feldspar porphyroclasts that lie within a moderate to strong foliation (e.g. Figure 2.4b, Station C039, Map 2; back pocket). Outcrops located within the repeated basement slices in the central $F_{2 b}$ (SE) synclinal keel of the southeast domain, such as at station W024 (Map 2; back pocket), are typically fine to medium grained, and contain a strong foliation and localized mylonite zones. At this station, outcrops are characterized by dominantly dark grey-weathering, biotite and hornblende-rich monzogranite interlayered with $1-3 \mathrm{~mm}$ thick cream coloured quartzofeldspathic layers and ribbons with intermittent $1-2 \mathrm{~cm}$ thick lenses and clots (Figure 2.4c). Flattened and stretched $2-$ $25 \mathrm{~cm}$ long diorite pods and boudins, often rimmed by mm-thick bands of quartz and feldspar, occur within the biotite-hornblende monzogranite (Figure 2.4c). Elsewhere, the monzogranite outcrops exhibit strong contrasting compositional layering on a scale of $\sim 5$ $-15 \mathrm{~mm}$, often folded and distorted, with alternating biotite-rich bands and quartz and feldspar-rich bands (e.g. Figure 2.4d, Station W014, Map 2; back pocket).

In general appearance, the monzogranite unit differs from the granodiorite unit (unit 1a - Agd) in that the thickness of the alternating biotite-rich layers and leucocratic layers in the monzogranite tend to be much finer than in the granodiorite, and the monzogranite has a greater abundance of $0.5-2 \mathrm{~cm}$ long alkali-feldspar porphyroclasts. In hand specimen and thin section, the monzogranite is typically medium to coarsegrained, well-foliated, and inequigranular with $0.5-2 \mathrm{~cm}$ long microcline porphyroclasts within a fine to medium-grained matrix composed of quartz, microcline, plagioclase, 
biotite, and hornblende (Figure 2.5a). The alkali-feldspar was identified as microcline based on the plaid twinning in thin section. The foliation is typically defined by the alignment of biotite grains and flattened quartz and alkali-feldspar crystals and crystal aggregates (Figure $2.5 b)$.

\subsubsection{Unit 1c: biotite-hornblende-muscovite tonalite}

The gneissic biotite-hornblende-muscovite tonalite, predominantly exposed in the western part of the map area, occurs within the granodiorite unit, as mappable layers and masses covering up to $\sim 1.5 \mathrm{~km}^{-2}$ in area. The tonalite has a minimum structural thickness of $250 \mathrm{~m}$ and has been traced $\sim 1.5 \mathrm{~km}$ along strike. Directly north of Amittuq Lake, the tonalite is exposed in the 'B0' and ' $\mathrm{B} 1$ ' basement domains as continuous masses, $\sim 1.5$ to $3.5 \mathrm{~km}$ northwest of Amittuq Lake. The tonalite is exposed as pods and lenses in the 'B4', 'B5" and 'B7' basement domains as isolated areas of $\sim 0.5 \mathrm{~km}^{-2}$ in size. To the west of Amittuq Lake, it is less clear as to which basement domain the mapped tonalite masses belong to. However, based on the projected geometries of map units, the majority of the tonalite masses apparently occur in the 'B0' and 'B5' basement domains (Map 1, in back pocket).

The gneissic tonalite unit has diffuse, irregular contacts with the enclosing granodiorite unit. Although complex infolding of tonalite and granodiorite layers is common everywhere, the different rock types are discrete and there appears to be limited intermixing of the two units. In addition to compositional variations, diagnostic features such as the more felsic composition of the tonalite, and the decreased abundance of mafic mineral-rich bands and quartzofeldspathic veins in the tonalite relative to the 
granodiorite, distinguish gneissic tonalite (e.g. Figure 2.6a, Station L095, Map 2; back pocket) from the surrounding granodiorite (Figure 2.3b). Typically, the gneissic tonalite outcrops as smooth, massive surfaces.

The tonalite, as well as the granodiorite, is host to an $\sim 1 \mathrm{~km}^{-2}$ area of weakly foliated, biotite syenogranite (Unit 6, Map 1; back pocket), which crosscuts the gneissic banding in the tonalite and granodiorite and is interpreted to be a pluton. The syenogranite pluton has diffusive to sharp intrusive contacts and local 1-2 mm thick chilled margins (described in detail in section 2.2.3).

The tonalite is also host to $\mathrm{cm}$ - to m-thick lenses, blocks and distorted bands of dark grey-weathering dioritic - gabbroic material. The mafic material is often deformed and complexly folded (e.g. Figure 2.6b, Station C036, Map 2; back pocket).

In outcrop the gneissic biotite-hornblende tonalite consists predominantly of a white- to light grey-weathering, gneissic biotite-hornblende tonalite, interlayered with continuous bands and layers of more intermediate to mafic material. This compositionally layered unit typically exhibits gneissic banding, which is rarely straight, but more commonly deformed and folded, defined by $2-30 \mathrm{~cm}$ thick alternating layers of light grey-weathering leucotonalite and dark grey-weathering biotite-hornblende tonalite (e.g. Figure 2.6c, Station D258, Map 2; back pocket). The contacts between layers of the two compositional variations is sharp.

In hand specimen, the tonalite is a fine to medium-grained, equigranular rock with a flecked salt and pepper light-grey colour on the fresh surface. Fine-grained biotite and hornblende form aggregates that are irregular, mm-thick lenses and layers that are concordant with the dominant gneissic foliation (e.g. Figure 2.6d, Station L047, Map 2; 
back pocket). Alkali-feldspar, where present, constitutes up to $5 \%$ of the bulk rock composition, and occurs as $3-8 \mathrm{~mm}$ long phenocrysts.

\subsubsection{Unit 1d: hornblende-biotite quartz-diorite to gabbro}

Mafic, amphibole-biotite-rich rocks are widespread throughout the study area in the Archean orthogneiss complex, although they typically only compose a small $(2-5$ $\%)$ part of any given basement outcrop. Hornblende-biotite quartz-diorite to gabbro occurs as $\mathrm{cm}$ - to m-thick inclusions within the surrounding granodiorite, monzogranite and tonalite units. There are three distinct associations of $>30 \mathrm{~cm}$ thick blocks or layers of mafic bodies: firstly, continuous mafic layers within a felsic host rock (e.g. Figure 2.7a, Station L087, Map 2; back pocket); secondly, as thinly banded mafic layers within a composite host rock of more than one felsic composition (Figure 2.3c); and thirdly, as isolated deformed lenses, enclaves or boudins within the felsic host rocks (Figure 2.6b).

The first association, comprising continuous layers of mafic rocks (Figure 2.7a), occurs throughout the study area, but notable locations include stations L087 and L095 in the northwest domain, and C038 in the southeast domain. The second type is prominent within the higher strained repeated basement slices 'B1' to 'B7', and may represent a deformed and thinned equivalent of the first type (Figure 2.3c). The third type is prominent throughout the basement complex as distorted lenticular layers and boudins within the felsic granitoids (Figure 2.4c, 2.6b).

In hand specimen and thin section, the amphibole-rich quartz diorite to gabbro is fine grained, equigranular, and weathers a dark grey-green to black. The fresh surface is typically dark grey-green. The mafic minerals are dominated by $\sim 50 \%$ amphibole and $\sim 5$ 
$\%$ biotite, whereas the felsic minerals comprise $\sim 35 \%$ plagioclase and $\sim 10 \%$ quartz (e.g. Figure 2.7b, c, Station C038, Map 2; back pocket). Amphibole is interpreted as hornblende based on $56^{\circ}$ and $124^{\circ}$ cleavage in thin section, higher indices and smaller extinction angle compared to actinolite, and darker colour and higher indices compared to tremolite. Where present, a weak foliation is defined by the alignment of flattened aggregates of hornblende and plagioclase (2:1 aspect ratio) and fine-grained biotite grains (Figure $2.7 \mathrm{c}, \mathrm{d}$ ).

\subsubsection{Paleoproterozoic Lake Harbour Group cover rocks (Units 2 - 5)}

The Paleoproterozoic Lake Harbour group cover rocks, consist predominantly of variably deformed quartzite $\left(\mathrm{Pqz}_{\mathrm{L}}\right)$, psammitic to pelitic schist $\left(\mathrm{Pps}_{\mathrm{L}}\right)$, amphibolite $\left(\mathrm{Pa}_{\mathrm{L}}\right)$, and calc-silicate ( $\mathrm{Pc}_{\mathrm{L}}$, Map 1; back pocket). The cover rocks have a minimum structural thickness of $\sim 80 \mathrm{~m}$ in the study area. A maximum depositional age of ca. $1967 \pm 8 \mathrm{Ma}$ (Rayner, 2015) was obtained for a representative sample of psammitic schist (Station S139, Map 2; back pocket) collected from the Ptarmigan Fiord (see section 2.2.2.2). Descriptions of the cover units are presented in a relative, but not absolute, order or lithotectonic sequence, as constrained in the field, and as illustrated in the lithological column of Figure 2.1.

Based on observations of repeated exposures of basement-cover units and on mapping within individual cover slices (' $\mathrm{C} 0$ ' - ' $\mathrm{C} 6$ ', Map 1; back pocket), the typical basal unit for the cover sequence that is interpreted to nonconformably overly the basement complex is a biotite-hornblende quartzite interlayered with biotite and hornblende-rich laminations (unit 2 - $P q z_{L}$ ). However, at some of the exposed basement- 
cover contacts, the basal unit comprises a biotite-muscovite psammitic schist, interlayered with garnet-sillimanite $\pm \mathrm{K}$-feldspar semipelitic to pelitic schist (Unit 3 $\left.P p s_{L}\right)$. Typically, a layer of garnet-orthopyroxene amphibolite (unit $4-P a_{L}$ ) structurally overlies Unit 3 schist, and a layer of wollastonite-tremolite calc-silicate (unit $5-\mathrm{Pc}_{\mathrm{L}}$ ) structurally overlies the unit 4 amphibolite (Figure 2.1).

The unit 3 schist is the most extensive cover unit in the study area (Map 1; back pocket) and typically contains $\mathrm{cm}$-to-m thick non-continuous interlayers and selvages of quartzite, amphibolite or calc-silicate rock types (Figure 2.1). Compositional layering with sharp to gradational contacts (described in section 2.2.2.2), interpreted as transposed bedding $\left(\mathrm{S}_{0}\right)$, are the only primary structures in the cover rocks.

\subsubsection{Unit 2: biotite-hornblende quartzite}

Quartzite occurs as distinctive marker layers that vary in thickness between $10 \mathrm{~cm}$ and $10 \mathrm{~m}$ or more, and average $0.5-5 \mathrm{~m}$ thick. Quartzite has two prominent associations: a) as a basal unit at the non-conformable contact between the basement and cover rocks throughout the study area (Figure 2.1, Figure 2.8a); and b) as $20 \mathrm{~cm}-1 \mathrm{~m}$ thick layers, largely interbedded with psammitic or pelitic schist of Unit 3 (Figure 2.1,2.8b). Locally, quartzite is interlayered with calc-silicate or amphibolite.

Quartzite locally forms prominent scarps and dip slopes. It is often white or grey, weathers pale orange, grey-blue, or light-grey, and is fine grained (Figure 2.8a, b). It may contain less than $1 \%$ of minerals other than quartz. For example often biotite and white mica are concentrated in layers that are less than $1 \mathrm{~mm}$ thick. Most quartzite contains trace amounts of randomly distributed K-feldspar and plagioclase. The quartzite 
commonly contains $5-10 \%$ biotite and hornblende in $\sim 1-10 \mathrm{~mm}$ thick continuous bands and layers, which are interpreted to represent primary compositional variation (Figure 2.8c).

In thin section, quartz grains typically exhibit two distinct grain sizes (i.e. coarser 1-2 $\mathrm{mm}$ diameter grains and $<1 \mathrm{~mm}$ diameter grains), which are aligned in alternating bands defining a foliation (Figure 2.8d). Parallel bands of alternating bimodal grain size could represent variations in primary sedimentary grain size. Alternatively, or in combination, the bimodal grain size could be the result of variations in finite strain during in the foliation forming event. The coarse and finer grains themselves are weakly to strongly flattened with aspect ratios of 2:1 to 10:1 aspect ratios, respectively, and the preferred dimensional orientation of grains defines a strong foliation. Quartz grains exhibit a weak granoblastic texture with interlobate grain boundaries and show little evidence of internal microstructures indicating that annealing has taken place subsequent to deformation that produced the strain related shape fabrics and macrostructures (Figure 2.8c, d). Fine grained biotite and white mica, aligned parallel to the foliation, separate coarse grain and fine grain layers, and potentially acted as pinning structures during annealing (Figure 2.8d). Annealing microstructures will be described in more detail in Chapter 3.

\subsubsection{Unit 3: biotite-muscovite psammitic schist interlayered with garnet-sillimanite \pm K-feldspar semipelitic to pelitic schist}

This compositionally heterogeneous unit is composed of two distinct units: a) fine- to medium-grained, migmatitic biotite-muscovite psammitic schist; and b) medium- 
to coarse-grained, migmatitic garnet-sillimanite $\pm \mathrm{K}$-feldspar e semipelitic to pelitic schist. A sample of psammitic schist from Ptarmigan Fiord cover rocks (S139, Map 2; back pocket) yielded a significant population of $1.96 \mathrm{Ga}$ zircon grains, based on $\mathrm{U}-\mathrm{Pb}$ single grain analyses, and replicate analyses of one of the youngest grains yields a maximum age of deposition at $1967 \pm 8 \mathrm{Ma}$ (Rayner, 2015), for at least part of the cover package.

Unit 3 schist has a minimum thickness of $60 \mathrm{~m}$, has been traced $\sim 12 \mathrm{~km}$ along strike, and typically weathers as recessive depressions and glaciated flat topped hills. All rock types in Unit 3 weather a rusty brown colour, which contrasts well with the lightgrey weathering basement unis and dark grey to black weathering amphibolite (Figure 2.2a, b); making it an easy marker layer to identify from the air or on traverse. The semipelitic to pelitic schist typically occur as $0.5-20 \mathrm{~m}$ thick interlayers within much thicker, $>20 \mathrm{~m}$ thick panels of psammitic schist. In the southeast domain, in cover sequence 'C3' (Map1; back pocket), $10-50 \mathrm{~cm}$ thick alternating sequences of pelitic psammitic schist exhibit both sharp and gradational contacts (e.g. Figure 2.9a, Station C086, Map 2; back pocket). These alternating interlayers are interpreted as representing primary compositional variations or bedding, termed $\mathrm{S}_{0}$.

At the outcrop scale, the more pelitic layers are distinctive due to $\sim 10-15 \%$, 1-2 cm long knots of sillimanite, quartz and $\pm \mathrm{K}$-feldspar, and rare 2-10 mm-thick coarsegrained garnet (Figure 2.9b). The sillimanite-quartz $\pm \mathrm{K}$-feldspar knots define a stretching lineation, and lie within a strong foliation defined by the alignment of medium-to coarsegrained biotite, and fine-grained quartz and muscovite (Figure 2.9a, b). In the eastern part of the study area (stations C062, W078, Map 2; back pocket), within the cover sequences in the northern domain (' $\mathrm{C}_{\mathrm{ND}}$ ') and southeast domain (' $\left.\mathrm{C}_{0}{ }^{\prime}\right), 1-3 \mathrm{~m}$ thick layers of garnet- 
muscovite-sillimanite schist are studded with 5-20 mm diameter garnet (Figure 2.10a-c) and are distinctive marker units.

Leucogranite veins and dykes, $1-30 \mathrm{~cm}$ thick, occur within Unit 3 pelitic schist throughout the study area (Figure 2.10a, d). The light-grey to cream-coloured leucogranite contains $\mathrm{mm}$ - to $\mathrm{cm}$-sized lilac-coloured garnets within mats of fine sillimanite needles. The leucogranite veins are aligned parallel to the dominant foliation $\left(\mathrm{S}_{2 \mathrm{a}}\right)$, were folded by $\mathrm{F}_{2 \mathrm{~b}}$ and $\mathrm{F}_{3 \mathrm{a}}$ macroscopic and regional scale folds (Figure 2.10d), and 1-10 mm thick leucogranite veinlets are aligned within the axial-planar surface of $F_{2 b}$ (SE) generation folds (to be discussed in Chapter 3).

In hand specimen and thin section, the matrix of the psammitic schist is dominated by $\sim 60 \%$ fine-grained, equigranular, granoblastic quartz, $\sim 5 \%$ fine-grained, equigranular plagioclase and $\sim 5 \%$ fine-grained, equigranular K-feldspar, and $\sim 30 \%$ fine-to coarse-grained, elongate biotite (Figure 2.11a-d). Biotite and rare fine-grained muscovite define a strong foliation in the rock (Figure 2.11a, c-d), and elongate biotite aggregates define a stretching lineation (Figure 2.11b). The matrix of the semipelitic to pelitic schist is typically composed of $\sim 30 \%$ fine-grained, equigranular, granoblastic quartz, $\sim 45 \%$ fine-to medium-grained biotite, coarse-grained, and $\sim 10 \%$ randomly oriented secondary (?) muscovite (Figure 2.9c, d). $15 \%$ coarse-grained sillimanite, fine-grained quartz, and traces of fine-grained K-feldspar are arranged in 1-2 cm long knots, which could represent relic faserkiesel textures (Figure 2.9b, c). Some thin sections contain up to $10 \%$ leucosome. A strong foliation is defined in the semipelitic to pelitic schist by the alignment of matrix biotite and quartz, and a stretching lineation is defined by the long axis of sillimanite-quartz $\pm \mathrm{K}$-feldspar knots (Figure $2.9 \mathrm{~b}$ ). 


\subsubsection{Unit 4: garnet-orthopyroxene amphibolite}

Mafic amphibole-rich rocks are widespread in the cover rocks of the Ptarmigan Fiord area, although they comprise only a small part of the total outcrop area. The fine grained, black- to dark green-weathering garnet-orthopyroxene amphibolite unit, occurs in distinctive layers up to $30 \mathrm{~m}$ thick, typically above the Unit 3 psammitic and pelitic schist (Figure 2.1 and 2.2). The amphibolite also occurs as 2-10 $\mathrm{m}$ thick resistive layers within the rusty-brown weathering Unit 3 metasedimentary units, and as 2-5 m thick, moderately- to highly-strained panels at the top of the cover rocks, adjacent to overlying basement imbricates 'B1' - 'B6' (e.g. Figure 2.12a, station C086, Map 2; back pocket). Unit 4 often occurs as a distinct marker layer in cliff faces, and typically the overall unit thickness is preserved in the limbs and hinges of cliff-scale folds (Figure 2.2).

In hand specimen and thin section, the amphibolite is dark grey-to-green, consisting typically of $\sim 50 \%$ fine-grained, subhedral, flattened hornblende in planar and linear array, $\sim 20 \%$ fine-grained plagioclase that often has sericite replacement along grain boundaries, and $\sim 20 \%$ fine-grained, granoblastic quartz (Figure 2.12c-d). The remaining $\sim 10 \%$ includes rare medium-grained, euhedral garnet, medium-to coarsegrained orthopyroxene, and fine-grained biotite or dolomite (Figure 2.13 a-d). Rare mmthick calcite and dolomite veins occur in some outcrops, and may have a metamorphic or hydrothermal origin. The preferential alignment of weakly flattened hornblende and biotite grains defines a moderate to strong foliation in most samples. A stretching lineation in high-strain equivalents is defined by the long axis of elongate hornblende grains. 


\subsubsection{Unit 5: wollastonite-tremolite calc-silicate}

White- to dark grey-weathering calc-silicate, occurring as $0.5-1 \mathrm{~m}$ layers, typically overlie the amphibolite in Ptarmigan Fiord cover sequences, but also occur as cm-to m-thick discontinuous layers or lenses within in the psammitic and pelitic schist units (Figure 2.1). Discontinuities along strike of the wollastonite-tremolite calc-silicate are presumably related to changes in the bulk composition or tectonic attenuation. Layers of calc-silicate vary in thickness from $3-5 \mathrm{~m}$ to less than $0.5 \mathrm{~m}$. Though the thickness of the later is exaggerated on the map for legibility, their value as marker horizons justifies their inclusion. Outcrops weather as non-resistive, rubbly flat surfaces, or as recessive layers when in contact with more competent cover units (Figure 2.14a).

In hand specimen and thin section, the fresh surface of the calc-silicate is white, pale grey or cream-coloured, and is typically composed of $>80 \%$ fine-grained dolomite and calcite (Figure 2.14.a), and $\sim 20 \%$ silicate minerals such as fine-to coarse-grained tremolite (occurring as 2-5 cm knots), and coarse-grained wollastonite (Figure 2.14a, b). Tremolite is typically aligned within the dominant foliation (Figure 2.14a). In thin section, fine-grained dolomite and calcite are equigranular and granoblastic (Figure 2.14c), perhaps due to annealing. A weak foliation is defined by weakly flattened carbonate minerals and fine-grained tremolite, arranged in parallel 2-3 mm thick mats (Figure 2.14c). 


\subsubsection{Paleoproterozoic syenogranite (Unit 6)}

A red- to pink-weathering, weakly-foliated, medium-grained, homogeneous biotite syenogranite pluton (Unit 6) outcrops near the western margin of the map area, and has an estimated areal extent of $\sim 1 \mathrm{~km}^{-2}$ (Map 1; back pocket). Unit 6 crosscuts the gneissic foliation within the basement rocks (Figure 2.15a), and is therefore younger than the basement granitoids and the foliation within them. 1- to 2-m thick, foliated, syenogranite and pegmatitic syenogranite dykes, of similar character as Unit 6, occur within the basement and cover imbricates in the southeast and northwest domains (Figure F, Map 1; back pocket). Crosscutting relationships between the intrusions and the contacts between basement and cover rocks were not observed. The absolute crystallization ages of these m-scale syenogranite and pegmatite dykes are uncertain, but they may be related to Unit 6 in the western part of the study area.

A sample of Unit 6 from the major intrusion (15SAB-C117A2; Sample map; back pocket) was collected and dated using $\mathrm{U}-\mathrm{Pb}$ zircon SHRIMP geochronology, resulting in zircon rim ages of ca. $1861 \pm 2 \mathrm{Ma}$ and zircon core ages of ca. $2729 \pm 5 \mathrm{Ma}$ according to N. Rayner (unpublished data, 12 December 2016). The Archean core ages are interpreted to represent inherited zircon ages, while the Paleoproterozoic rim ages are interpreted as the igneous crystallization age of the syenogranite according to N. Rayner (unpublished data, 12 December 2016).

In hand specimen, Unit 6 comprises $\sim 45 \%$ pink-weathering, medium-grained, equigranular, euhedral K-feldspar, 5\% white-weathering fine-to medium-grained plagioclase, $\sim 40 \%$ medium-grained granoblastic quartz, and $\sim 10 \%$ medium-grained 
biotite (Figure 2.15c). A weak foliation is defined in the rock by the preferential alignment of biotite grains into $1-3 \mathrm{~mm}$ bands (Figure 2.15c).

\subsection{Interpretations and conclusions of Ptarmigan Fiord map units}

\subsubsection{Potential protoliths for unit 1}

Crystalline basement in the Ptarmigan Fiord area comprises an orthogneiss complex. The gneisses are interpreted to have igneous protoliths for a number of reasons. The quartz, K-feldspar, and plagioclase-rich mineral assemblages are typical of granitoids. Coarse-grained, interlocking mineral textures are interpreted as relict igneous textures. Relative homogeneity of each unit is typical for an igneous intrusive rock. Aluminous metamorphic minerals such as garnet, muscovite, and biotite (i.e. typical of mud-rich protoliths) are largely absent or are minor mineral constituents. Basement units in areas of inferred low strain are relatively homogenous, and do not show evidence of compositional layering. Therefore, meta-igneous rocks mapped in the Ptarmigan Fiord basement complex are likely similar in character as the igneous protoliths (granodiorite, monzogranite, tonalite, and quartz diorite to gabbro; in decreasing order of abundance), and preserve the same intrusive cross-cutting relationships.

The monzogranite and tonalite units are both mapped as enclosed units within the voluminous granodiorite unit. This field relationship suggests that the more felsic monzogranite and tonalitic units were emplaced and crystalized prior to the emplacement of the more intermediate granodiorite. On the other hand, the tonalitic to monzogranitic rocks could have intruded into the granodiorite after it crystalized. Therefore, with the 
present knowledge of cross-cutting relationships in the basement complex and the lack of absolute ages for the granodiorite and monzogranite units, it is impossible to interpret the relative emplacement timing of granodiorite, monzogranite, and tonalite. Details about the timing of emplacement of Archean basement units, with potential implications for the evolution of the basement complex, will be presented in the following section with the integration of regional studies.

A variety of field relationships for quartz diorite to gabbro relative to other map units have been documented, including entrainment as boudins, irregular xenoliths, or outcrop-scale blocks in the felsic basement units. The irregularly shaped xenoliths and blocks of mafic rocks could be interpreted as rafts of older country rock that existed prior to the emplacement of the more felsic basement rock type. It is also possible that the mafic boudins and pods were originally emplaced in the more felsic basement rocks as younger dykes and sills, after crystallization of the felsic plutonic suite. Therefore, there may be older and/or younger constituents of mafic material in the Ptarmigan Fiord basement complex, which may predate or be younger than the felsic host rocks. Possible origins of these mafic amphibole-rich rocks will be discussed in the following section, with the integration of regional geochemical and geochronological studies on Hall Peninsula. Finally, the youngest unit in the basement is the syenogranite intrusion (Unit 6), which crosscuts the gneissic foliation in all basement rocks.

\subsubsection{Potential protoliths and depositional settings of cover rocks}

The following section presents the protolith interpretation for each metasedimentary unit, and possible depositional setting of the cover sequence in the 
Ptarmigan Fiord area. This is followed by an interpretation of the amphibolite (Unit 4) and its relationship to the metasedimentary units. In general, there is a heterogeneous distribution of rock types within individual cover slices in the area, and a lack of recognizable primary structures, which limits the interpretation.

The protolith for the biotite-hornblende-bearing quartzite (Unit 2) is interpreted to be a mature, well sorted quartz arenite, based on the dominance of fine-grained, equigranular quartz. The 1-20 mm thick biotite- and amphibole-rich mafic layers that are found within the 'clean' quartzite, and are interpreted as possible metamorphosed ash layers, based on the presence of the mafic minerals.

The interlayered psammitic schist and semipelitic-to-pelitic schist (Unit 3) are interpreted to reflect original compositional layering of arkosic wacke and mudstone. In some outcrops, there appears to be grading from psammitic schist to pelitic schist, with upward fining of grain size, which could be interpreted as the result of deposition by turbidity flows (Bouma, 1962). However, turbidity flows can occur in a variety of settings and data are insufficient to constrain the depositional environment.

The wollastonite-tremolite calc-silicate (Unit 5), which is largely dominated by fine-grained dolomite and calcite, is interpreted to have a carbonate rock protolith. The presence of minor silicate minerals such as wollastonite and tremolite suggests that there was silicate input into the carbonate unit, perhaps in the form of quartz grains from a clastic source. Alternatively, the calc-silicate minerals could be the result of siliceous cement or siliceous fluids as well as siliciclastic sedimentary grains. These characteristics are consistent with deposition in a potential shallow marine environment, such as a continental shelf. 
It is unclear if the amphibolite (Unit 4) in the cover rocks represents original volcanic horizons, such as flows or mafic sills. The emplacement of Unit 4 is unclear based on contact relationships with the metasedimentary units, and two broad interpretations are possible. The first interpretation is that Unit 4 represents a mafic flow related to volcanism. The flows could have erupted and extruded onto Unit 2 and been overlain by Unit 5 to produce the inferred tectonostratigraphy in Figure 2.1. An alternative interpretation is that Unit 4 was a mafic intrusion that intruded along the contacts between Unit 3 and 5, and potentially along contacts between arkosic wacke and mudstone within Unit 3 . However, because the contacts between units in the study area could be primary or tectonic structures and there is a lack of primary igneous structures, one interpretation is not favoured over the other.

Based on the inferred tectonostratigraphy (Figure 2.1) and protoliths of cover units in the Ptarmigan Fiord area, Units 2, 3 and 5 were likely deposited in a variety of marine facies. These include a deep-water settings for mudstone and arkosic wacke deposition (i.e. perhaps a slope-rise setting), to shallow marine settings for arenite and carbonate deposition. The addition of mafic material (Unit 4) to the cover sequence could have occurred in a local rift environment.

\subsection{Discussion}

\subsubsection{Correlation of units 1 and 6 with the regional basement complex}

The Hall Peninsula Archean basement rocks have been characterized by From et al. (2013, 2014, and 2015), following detailed mapping, petrography, geochemistry, 
geochronology, and structural studies in an area located $\sim 100 \mathrm{~km} \mathrm{SSE}$ of the Ptarmigan Fiord area (Regional Geology Map, back pocket). These authors documented compositional, structural and metamorphic variations in the Archean basement. From et al. (2014) identified at least 8 different basement rock types within their study area. On the basis of similar mineralogy, textures and xenolith inclusions four of these units are similar to the Archean basement units in the Ptarmigan Fiord area. From et al. (2014) also identified crosscutting syenogranite intrusions that may correlate with the Paleoproterozoic syenogranite intrusions in the Ptarmigan Fiord basement (Unit 6). These comparisons are summarized in Table 2.1, along with known ages by Scott (1999), From et al. (2015), Rayner (2015), and this study N. Rayner (unpublished data, 12 December 2016).

The comparison of basement units in the two study areas is presented in terms of inferred oldest to youngest units, based on field relationships and absolute ages. The blocky lenses and rafts of quartz-diorite to gabbro (part of Unit 1d), interpreted, in part, to be the oldest basement rock in Ptarmigan Fiord area, is similar in character to the pyroxene diorite (Unit 1, Table 2.1) from the From et al. (2014) study area. The Unit 1d association of foliation-parallel mafic boudins in the Ptarmigan Fiord area, interpreted as deformed younger dykes, is not included in this comparison due to the different field relationship. Blocky mafic lenses in both study areas (Unit 1d and Unit 1) occur within felsic gneisses. From et al. (2015) dated pyroxene diorite (Unit 1, Table 2.1) and produced a ${ }^{207} \mathrm{~Pb} /{ }^{206} \mathrm{~Pb}$ weighted-mean age of ca. $2700 \pm 3 \mathrm{Ma}$. The grey tonalite gneiss (Unit 2; Table 2.1) hosting the mafic lens in this outcrop was also dated using U-Pb zircon geochronology, resulting in a crystallization age of ca. $2810 \pm 3$ Ma. These ages 
suggest that the Unit 1 mafic lenses are potentially younger intrusions in the older grey tonalite host rock, and that both units were deformed together by a younger regional deformation event (From et al., 2015)). From et al. (2015) also suggest that the Unit 1 mafic lenses could be older mafic xenoliths within the grey tonalite gneiss. This is based on the fact that whole-rock geochemistry of mafic lenses show they are silica undersaturated, which has been linked with the crystallization of baddeleyite rather than zircon (Allibon et al., 2011). Subsequent interaction between the mafic rock and surrounding tonalite during metamorphism could have caused the breakdown of baddeleyite and produced zircon during a tectonothermal event at ca. $2700 \mathrm{Ma}$ (From et al., 2015).

Regardless of how the regional pyroxene diorite formed (Unit 1; Table 2.1), the mineralogy and style of occurrence of Unit 1 is very similar to the associations of Unit 1d that occur as blocky enclaves and lenses in the other basement rocks in the Ptarmigan Fiord area, and at least parts of the two units may be related to one another. The Unit 1d association of foliation-parallel mafic boudins, may be the same age or younger than the ca. $2700 \mathrm{Ma}$ Unit 1 rocks. Whole-rock geochemistry and U-Pb zircon geochronology of Unit 1d would be required to further test this hypothesis.

With respect to the felsic and intermediate gneisses, the Ptarmigan Fiord monzogranite (Unit 1b) and tonalite (Unit 1c) are inferred to be younger than the granodiorite (Unit 1a), as field relationships suggest that Units $1 \mathrm{~b}$ and $1 \mathrm{c}$ intruded Unit 1a. If these three units are compared with similar rocks in the From et al. (2014) study area (Table 2.1), and assumed to correlate with one another, the granodiorite (Unit 1a) would be the oldest unit ( $2928 \pm 5 \mathrm{Ma}$ ), followed by the tonalite (Unit 1c, $2810 \pm 3 \mathrm{Ma}$ ) 
and then the monzogranite (Unit 1b, $2720 \pm 5 \mathrm{Ma}$ ). If the basement crosscutting relationships in the Ptarmigan Fiord area are assumed to be correct, then these absolute ages would support the hypothesis that the voluminous felsic - intermediate granodiorite crystalized first prior to being intruded by younger, more felsic magmas. This broad sequence of mafic to intermediate to felsic compositions is a common trend observed in igneous rocks associated with convergent plate boundaries (Philpotts, 1990), and may provide some insight into the tectonic evolution of the Archean basement.

Finally, the syenogranite intrusions in both study areas could potentially be correlated based on similar composition and texture, both are weakly deformed, and both crosscut the other basement units (Table 2.1). There are not age data for this rock type from the study area of From et al. (2015); however, Scott (1999) dated zircons in three separate granitic dykes that intrude gneiss along eastern coast of the Hall Peninsula using the isotope dilution-thermal ionization mass spectrometry (ID-TIMS) U-Pb method. Zircon data yielded ages of $2835 \pm 11 \mathrm{Ma}, 2768 \pm 13 \mathrm{Ma}$, and $2820 \pm 5 \mathrm{Ma}$, whereas titanite ages from the same samples returned much younger ages between ca. 1730 and 1842 Ma. Consequently, Archean zircon from these intrusions were interpreted to have grown during initial emplacement of the dykes or been inherited as xenocrysts within Paleoproterozoic granitic dykes (Scott, 1999). If the latter is correct, then the granitic dykes could potentially be related to Unit 6 in the Ptarmigan Fiord study area, although there is an apparent $\sim 18 \mathrm{Ma}$ age difference between to the units in the two areas (Table 2.1).

The comparison of the Ptarmigan Fiord basement rock units with other basement rocks on Hall Peninsula is based on rock descriptions and field photographs (Table 2.1), 
and merely serves as a thought experiment for this discussion. More geochronological data are needed for Ptarmigan Fiord units in order to validate or modify the comparisons made in Table 2.1. However, if the rocks in both areas are similar, this comparative study reveals that perhaps there may be a higher degree of compositional complexity in the Ptarmigan fiord basement than has been currently recognized (i.e. potentially more than 4 units). This comparison also highlights the importance of conducting detailed mapping in the basement in order to properly constrain complex crosscutting relationships before integrating absolute age data, as there could be large ramifications for the interpreted tectonic models for the Archean basement.

\subsubsection{Correlation of units 2-5 with the regional Lake Harbour Group cover}

Similar to the Ptarmigan Fiord area, Archean orthogneiss on eastern Hall Peninsula is locally overlain by a metamorphosed Paleoproterozoic supracrustal sequence (i.e. the Lake Harbour Group), separated from the orthogneiss by nonconformable contacts (Steenkamp and St-Onge, 2014, Figure B, Map 1; back pocket). The basal unit of the Lake Harbour sequence is a $1-25 \mathrm{~m}$ thick layer of blue-grey weathering quartzite, which contains relic heavy mineral bands defining primary bedding. Similar to the quartzite at Ptarmigan Fiord, the basal quartzite was observed to be in contact with Archean orthogneiss at several locations. However, the basal unit in the Ptarmigan Fiord area varies between quartzite and semipelitic to pelitic schist. The reason for the variation in the basal unit is unclear, but one explanation might be that transposition during a regional tectonothermal event structurally modified the unit thicknesses, or repeated the original stratigraphy, resulting in varying cover units above the repeated basement slices. 
Alternatively, the variable basal unit may be a primary feature, reflecting an original variation in deposition of sand, silt and clay onto the orthogneiss basement complex.

Overlying the Lake Harbour Group quartzite on Hall Peninsula is a $600 \mathrm{~m}$ thick unit of grey-to rusty brown-weathering, alternating psammitic, semipelitic and pelitic schist. Above this lies a $100-400 \mathrm{~m}$ thick unit comprising interlayered semipelitic schist, calc-silicate, meta-ironstone, and amphibolite (Steenkamp and St-Onge, 2014).

The supracrustal sequence was interpreted by Steenkamp and St-Onge (2014) as a proximal shallow-marine to more distal continental-shelf and slope-rise depositional setting, with input of mafic material potentially from a local rift environment. The overall regional tectonostratigraphy of the Lake Harbour Group is similar to the inferred tectonostratigraphy in the Ptarmigan Fiord area (Figure 2.1), and may help to constrain the depositional environment of the mapped cover rocks.

Finally, the constraints on the origin of the mafic cover rocks in the area may be inferred from geochemical studies. Whole-rock major- and trace-element geochemistry of 64 samples of mafic and ultramafic rocks from southern Hall Peninsula was conducted by MacKay and Ansdell (2014). The mafic and ultramafic rocks are interpreted as intrusions into metasedimentary cover units (similar to Unit 4 at Ptarmigan Fiord). The mafic rocks have normal mid-ocean-ridge-basalt-normalized Th, $\mathrm{Ce}, \mathrm{Zr}$, Ti and $\mathrm{Y}$ concentrations typical of within-plate environments, and strong negative $\mathrm{Nb}$ anomalies, which suggest that the rocks were derived from partial melting of a subduction-modified mantle (MacKay and Ansdell, 2014). The geochemistry supports emplacement in a rift environment, and the lack of pillow or quench structures suggests that mafic and ultramafic rocks were emplaced as intrusions into the metasedimentary rocks. The mafic 
rocks on southern Hall Peninsula may correlate with those in the Ptarmigan Fiord area based on tectonostratigraphic and textural characteristics, and may provide insights into the tectonic regime of the latter.

\subsection{Summary and conclusions}

In summary, there are three main rock associations in the Ptarmigan Fiord area, which include: 1) an Archean orthogneiss basement complex consisting of variably deformed granodiorite (Unit 1a), monzogranite (Unit 1b), tonalite (Unit 1c), and quartz diorite to gabbro (Unit 1d); 2) Paleoproterozoic Lake Harbour Group cover rocks, which comprise predominantly deformed quartzite (Unit 2), psammitic to pelitic schist (Unit 3),

amphibolite (Unit 4), and calc-silicate (Unit 5); and 3) a Paleoproterozoic weakly-foliated syenogranite intrusion (Unit 6) that crosscuts basement units in the western part of the study area.

The Archean basement rocks, which make up the dominant rock assemblage in the study area and on northern Hall Peninsula, are interpreted to have a complex, protracted emplacement, metamorphic and deformation history, based on the overall lithologic heterogeneity of the basement, and geochronology studies of individual units (From et al., 2015; Rayner, 2015). The basement in the study area was intruded by a Paleoproterozoic syenogranite pluton, which may be related to $\mathrm{cm}$-to $\mathrm{m}$-thick syenogranite veins and pegmatites mapped throughout the study area. The basement is nonconformably overlain by Paleoproterozoic metasedimentary rocks, which are interpreted to have been deposited in a proximal shallow-marine to more distal 
continental-shelf and slope-rise depositional setting. This depositional environment is inferred from the mapped tectonostratigraphy in the study area, which broadly correlates with the regional tectonostratigraphy of the Lake Harbour Group (Scott, 1997; St-Onge et al., 2006; Machado et al., 2013a and b; Steenkamp and St-Onge; 2014). Mafic cover rocks within the metasedimentary units in the study area and Hall Peninsula, are interpreted as mafic intrusions related to rift magmatism derived from partial melting of a subduction-modified mantle. 
Figure 2.1. Lithotectonic section of basement and cover units in the Ptarmigan Fiord area (Map 1). See text for descriptions. Ages of domains are constrained from $\mathrm{U}-\mathrm{Pb}$ zircon geochronology (Rayner, 2015, unpublished data, 12 December, 2016). 


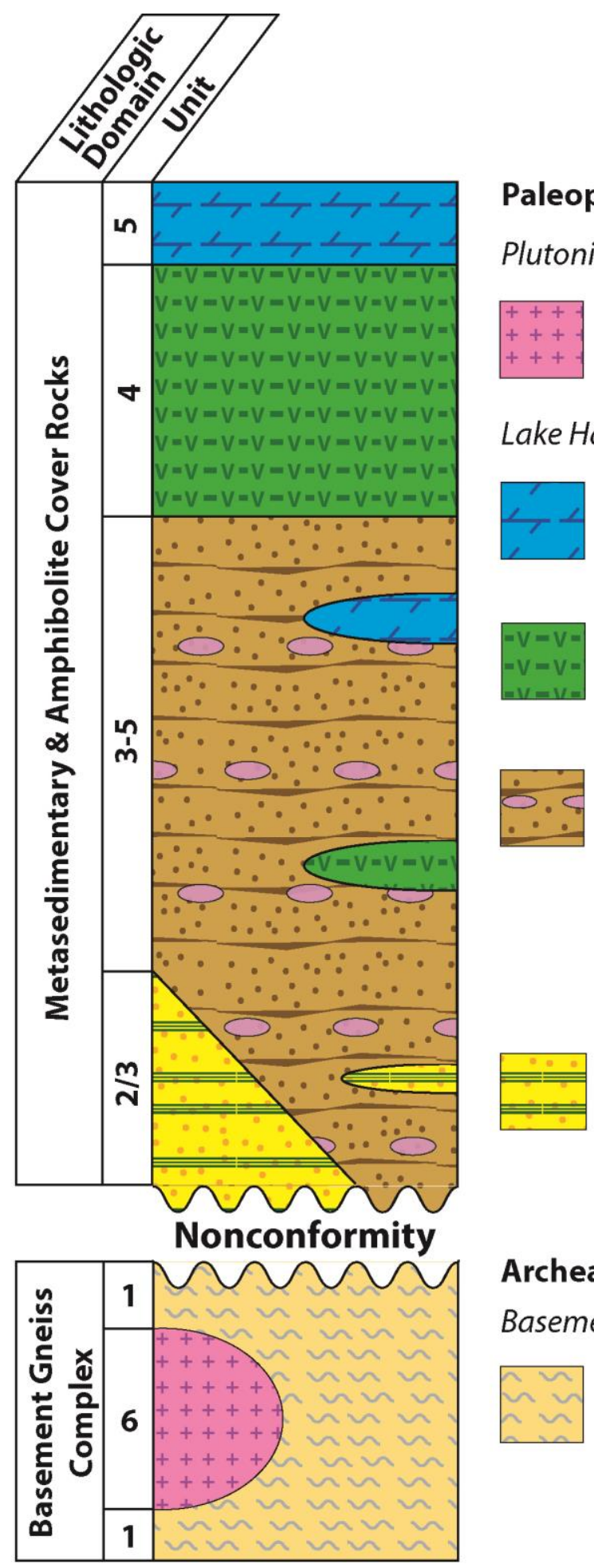

\section{Legend}

Paleoproterozoic ca. 1960 to $1861 \mathrm{Ma}$

Plutonic Rocks

Psg Unit 6: Bt syenogranite. Sample C117A2 dated at ca. $1861 \pm 2 \mathrm{Ma}^{* *}$.

$\mathrm{Pa}_{\mathrm{L}}$ Unit 4: Opx-Grt-Qz-Bt amphibolite.

Unit 3: Ms-Bt psammitic schist,

$\mathrm{Pps}_{\mathrm{L}}$ interlayered with $\pm \mathrm{Afs} \pm \mathrm{Ms}$-Sil-Grt-Bt semipelitic to pelitic schist. Unit often contains $0.1-1.5 \mathrm{~m}$ long rose quartz boudins. Detrital zircon dated at ca. $1967 \pm 8 \mathrm{Ma}^{*}$.

Pqz Unit 2: Hbl-Bt quartzite

$\mathbf{q} \mathbf{z}_{\mathbf{L}}$ interlayered with $\mathrm{Bt}-\mathrm{Hbl}$-rich laminations. Potentially the basal unit.

Agn

Unit 1: Archean orthogneiss basement complex consisting of variably deformed granodiorite (Unit 1a), monzogranite (Unit 1b), tonalite (Unit 1c), and quartz diorite to gabbro (Unit 1d).

* U-Pb zircon ages determined by Rayner (2015).

** U-Pb zircon age determed by N. Rayner (unpublished data, 12 December 2016). 
Figure 2.2. Panoramic photographs of the Ptarmigan Fiord geology, Hall Peninsula of Baffin Island. The area shown in the photographs are delineated on the Map 2 (back pocket): a) the photograph is taken from the helicopter (northward view) from a position on the base of the red rectangle labelled 'Figure 2.2a' on Map 2 (back pocket). Basement rocks are grey, metasedimentary clastic and pelitic cover rocks are brown, and metavolcanic rocks are dark grey. The stratigraphy preserved in the upright syncline is similar to that depicted in Figure 2.1 ; b) northwestward view facing $\sim 300^{\circ}$ azimuth. The photograph is taken from the helicopter from a position on the base of the blue rectangle labelled 'Figure 2.2b' on Map 2 (back pocket). Basement cover imbricates in the far distance ('B3' and 'C3') occur in the closure of an upright syncline in the southeast domain (Map 1). 

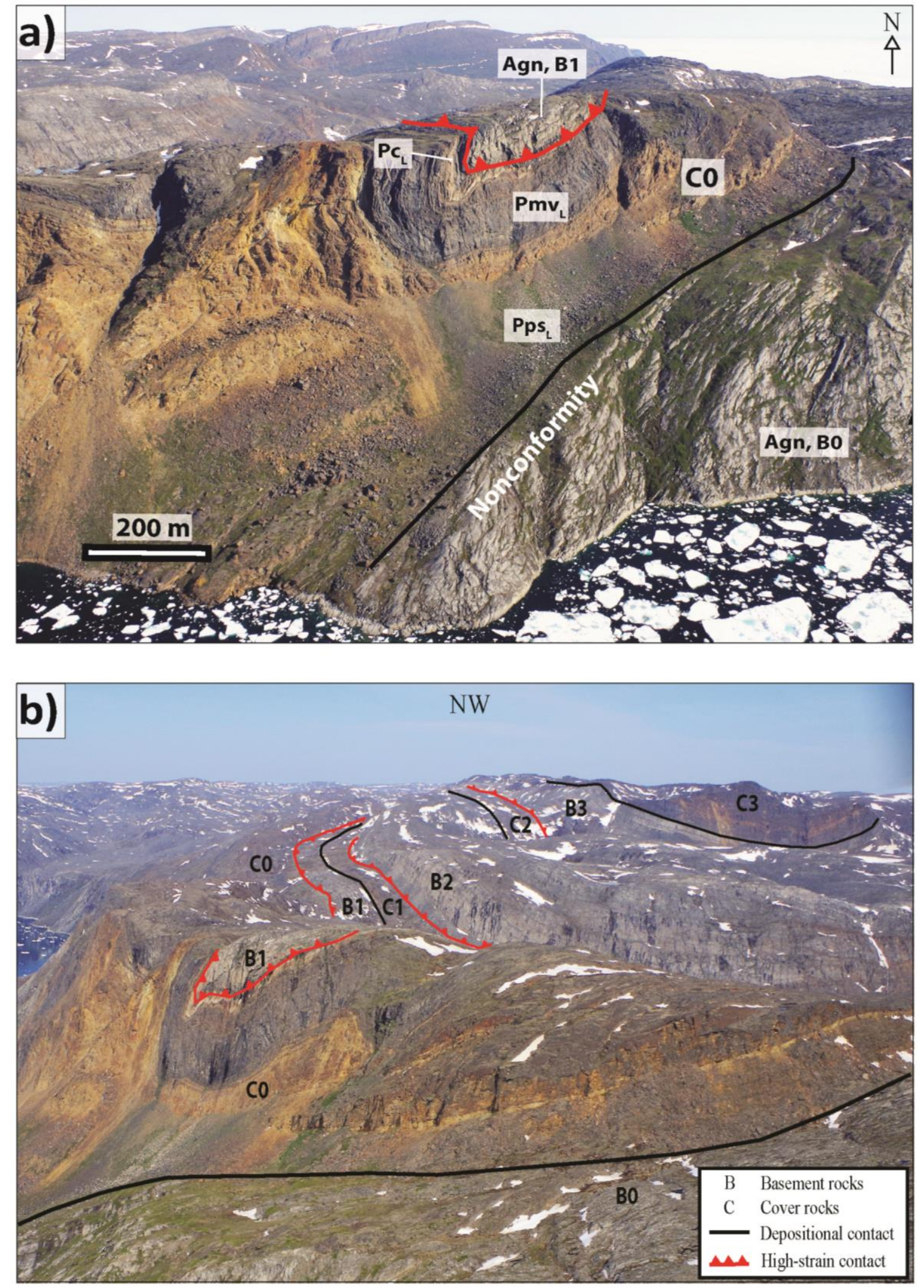
Figure 2.3. Outcrop and sample photographs of basement biotitehornblende \pm orthopyroxene granodiorite in the Ptarmigan Fiord area, Hall Peninsula of Baffin Island. a) light-grey weathering, medium-grained granodiorite veined with $\mathrm{cm}-$ thick quartzofeldspathic material (note the $60 \mathrm{~cm}$ long Remington 870 for scale); b) granodiorite exhibits strongly contrasting compositional layering on a scale of a $1-5 \mathrm{~cm}$, by the varying amount of hornblende and biotite in the layers (note the $30 \mathrm{~cm}$ long hammer for scale); c) light grey-weathering granodiorite is interlayered with rock types such as the quartz-diorite and syenogranite pegmatite, on a scale of $1-20 \mathrm{~cm}$ (note the $8 \mathrm{~cm}$ long scale card for scale). Westward view of top-side-to-the-southeast macroscopic shear-sense indicator, parallel to a moderately northwest-plunging lineation on a southwest-striking foliation, defined by extension of a biotite-rich layer in gneissic granodiorite basement; d) high strained granodiorite sample, where the effect of intense shearing as evident by the lenticular arrangement of mineral aggregates and flattened feldspar phenocrysts. Abbreviations: Gd, granodiorite; Sg, syenogranite; Qd, quartz diorite. 

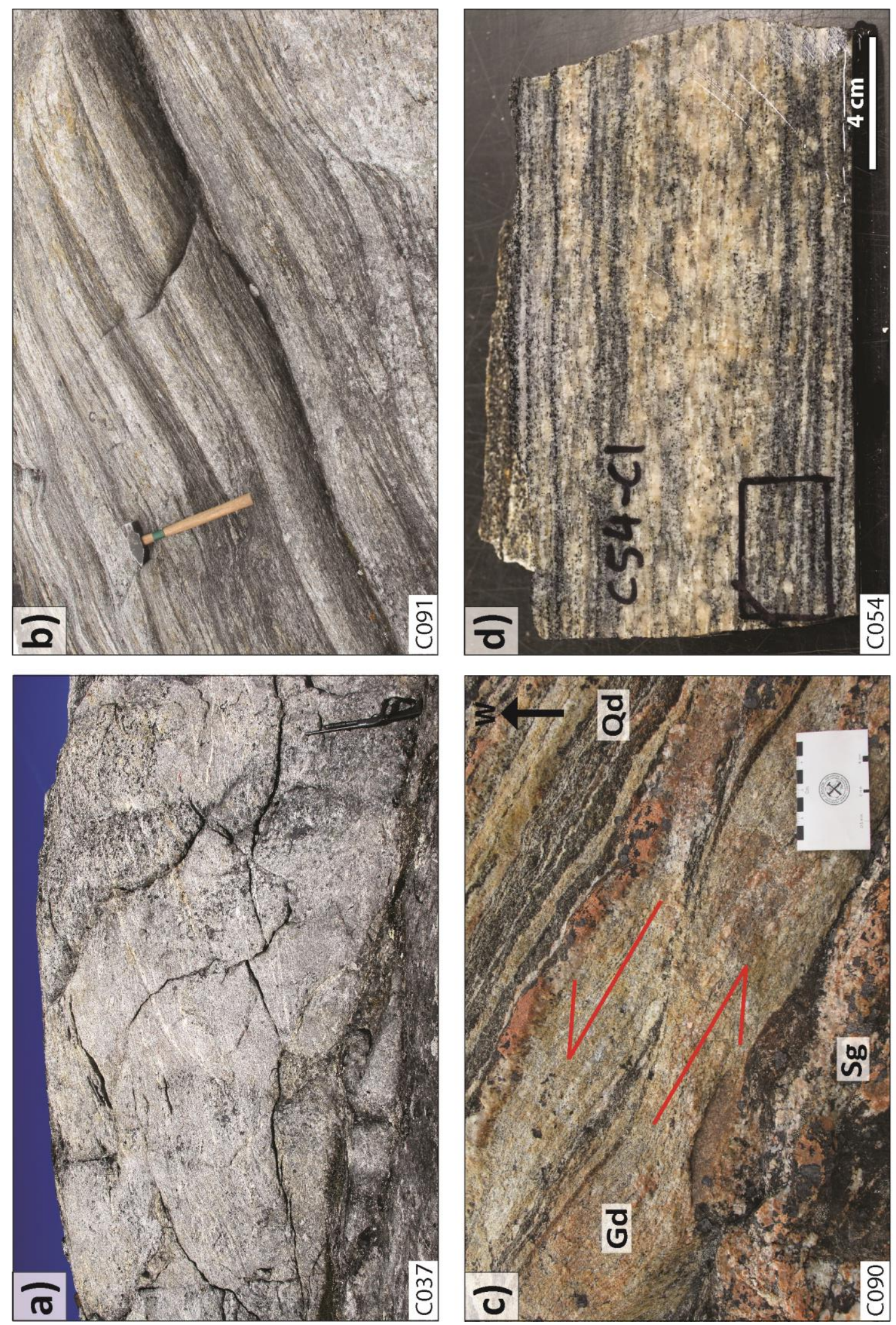
Figure 2.4. Outcrop photographs of basement biotite-hornblende monzogranite in Ptarmigan Fiord area, Hall Peninsula of Baffin Island. a) northward view of monzogranite outcrop in a high strain contact between basement - cover imbricates. Note that weathering is controlled by the strong foliation vs. the lower strain 'pavement' outcrop behind it; b) northward view of Archean basement monzogranite with rounded $\mathrm{K}$-feldspar porphyroclasts and $\mathrm{L}_{2 \mathrm{a}}$ stretching lineation (note the $8 \mathrm{~cm}$ long scale card for scale); c) flattened $2-25 \mathrm{~cm}$ long diorite pods and boudins, often rimmed by mm-thick bands of quartz and feldspar, are rarely present within the hornblende-biotite monzogranite, aligned parallel to the $\mathrm{S}_{2 \mathrm{a}}$ transposition foliation (note the $30 \mathrm{~cm}$ long hammer for scale); d) strong contrasting compositional layering in monzogranite on a scale of approximately $5-15 \mathrm{~mm}$, often folded and distorted, with alternating biotite-rich bands and quartz and feldspar-rich bands that could represent leucosome. Abbreviations: Afs, alkali-feldspar; Bt, biotite. 

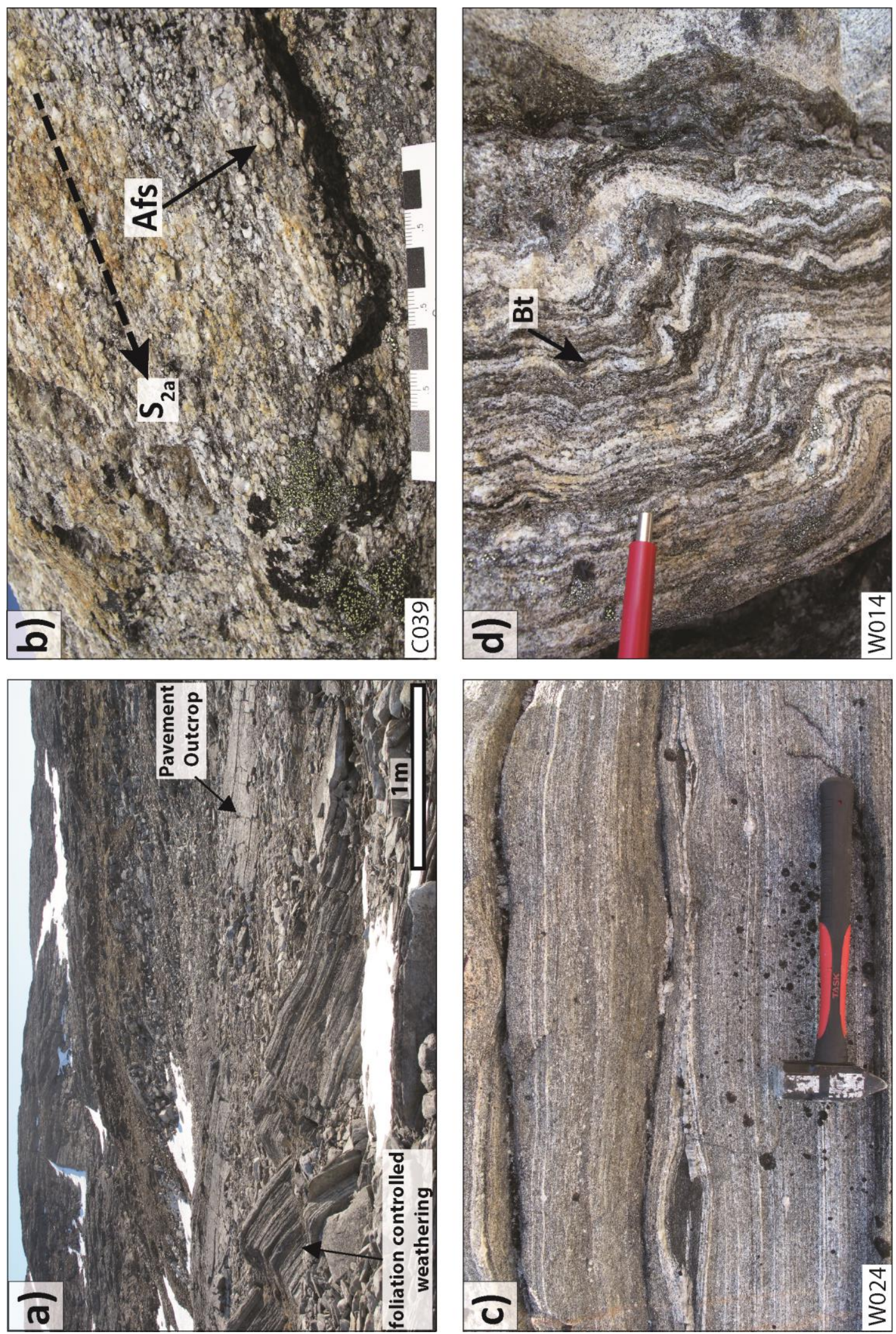
Figure 2.5. Sample photograph and photomicrograph in cross-polarized light of basement biotite-hornblende monzogranite in the Ptarmigan Fiord area, Hall Peninsula of Baffin Island. View is of the motion plane, cut parallel to the lineation and perpendicular to the foliation. a) a typical medium to coarse-grained monzogranite, which is wellfoliated, and inequigranular with $0.5-2 \mathrm{~cm}$ long microcline porphyroclasts within a fine to medium-grained matrix comprised of quartz, microcline, plagioclase, biotite, and hornblende; b) thin section photomicrograph of the same sample described in a). The foliation is typically defined by the alignment of flattened quartz and alkali-feldspar crystals, as well as biotite grains. Abbreviations: Afs, alkali-feldspar; Bt, biotite; quartz, Qz. 

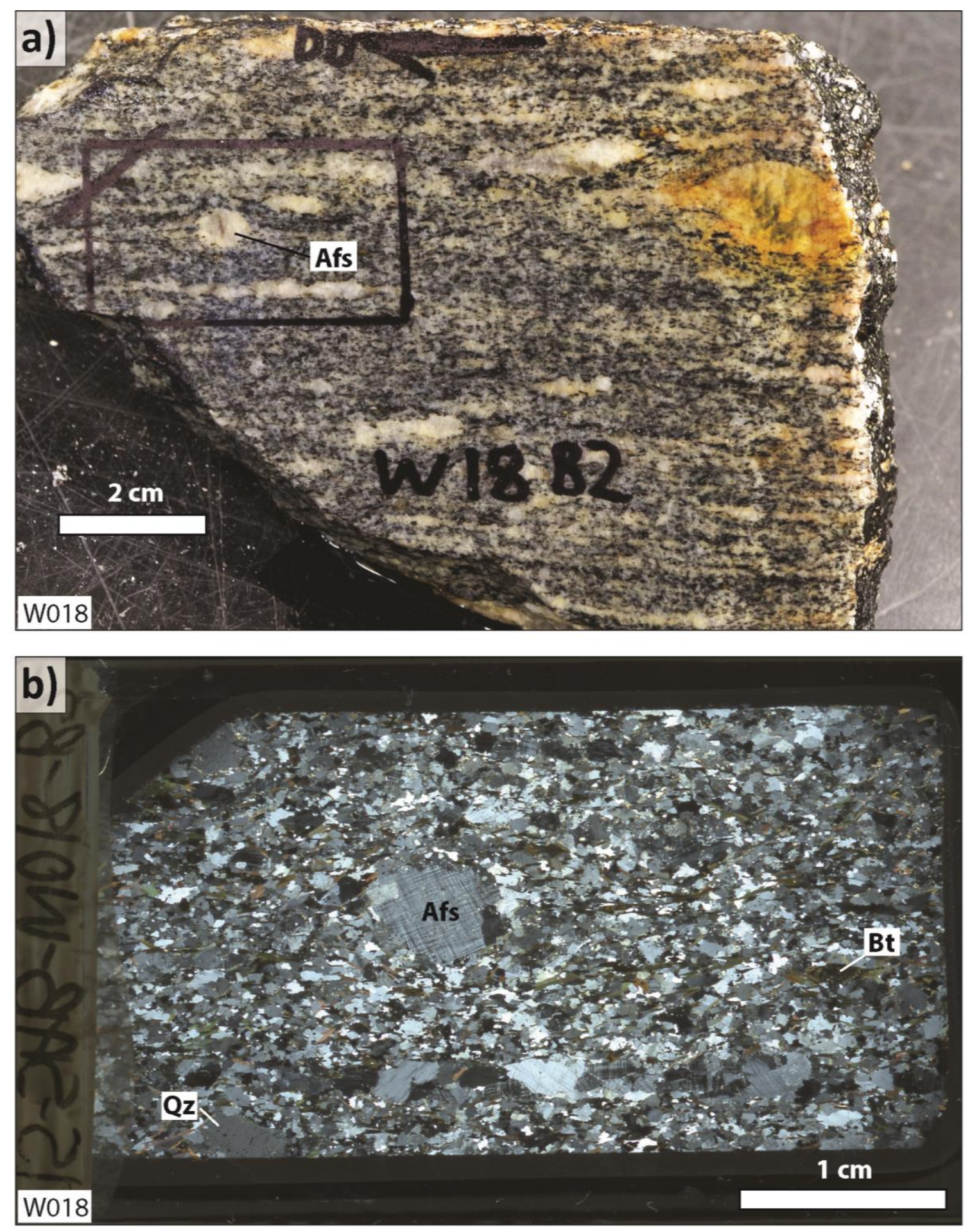
Figure 2.6. Outcrop and hand specimen photographs of basement biotite-hornblendemuscovite tonalite in the Ptarmigan Fiord area, Hall Peninsula of Baffin Island. a) northward view of light-grey weathering, medium-grained, strongly foliated tonalite, which is almost free of any mafic minerals (note the $30 \mathrm{~cm}$ long hammer for scale); b) northward view of Neoarchean basement tonalite with blocks and layers of quartz diorite (note the $30 \mathrm{~cm}$ long hammer for scale); c) compositional layering in tonalite is defined by $2-30 \mathrm{~cm}$ thick alternating layers of light grey-weathering leucocratic tonalite and dark grey-weathering biotite-hornblende-bearing tonalite (note the $8 \mathrm{~cm}$ long scale card for scale); d) hand specimen of tonalite showing fine-grained biotite and hornblende forming irregular, millimeter-long, linear aggregates aligned parallel to the dominant gneissic foliation. Abbreviations: Bt, biotite; QDr, quartz-diorite; Tn, tonalite. 

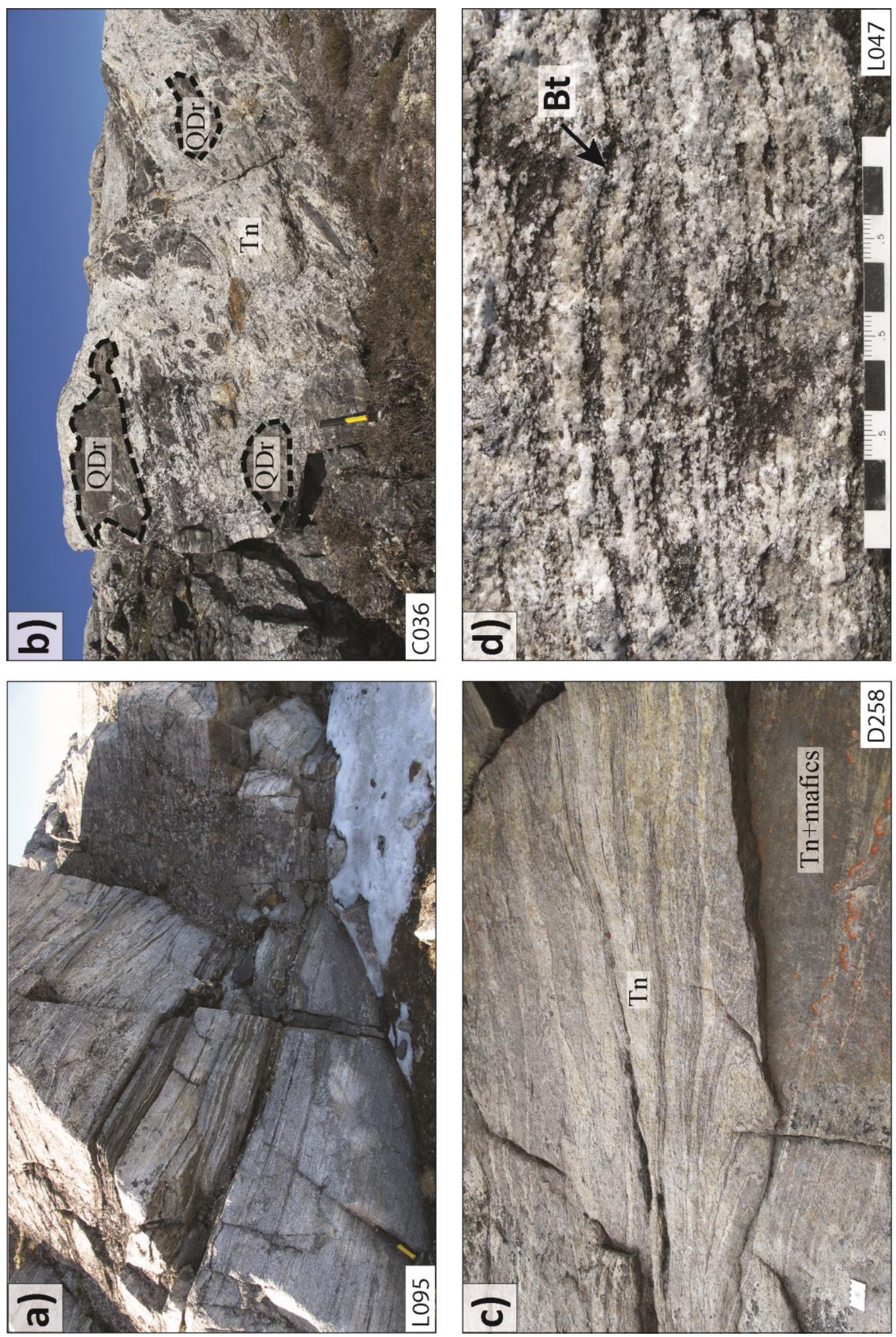
Figure 2.7. Photographs and photomicrographs, in plain-polarized light, of basement hornblende-biotite quartz-diorite to gabbro in the Ptarmigan Fiord area, Hall Peninsula of Baffin Island. a) dark-grey-green weathering blocky body and continuous band of basement diorite intruded by multiple generations of granitic veins (note the $30 \mathrm{~cm}$ long hammer for scale); b) hand specimen of fine grained, equigranular granodiorite. The fresh surface is typically dark grey-green; the mafic minerals are dominated by $\sim 50 \%$ amphibole and $\sim 5 \%$ biotite, and the felsic minerals comprise $\sim 35 \%$ plagioclase and $\sim$ $10 \%$ quartz; c) and d) thin section photomicrographs of quartz-diorite, in plain and cross-polarized light, showing the fine grained mineralogy and weak foliation defined by the alignment of flattened hornblende and plagioclase (2:1 aspect ratio) and fine-grained biotite grains in higher strained equivalents. Abbreviation: Bt, biotite; Hbl, hornblende; Pl, plagioclase; QDr, quartz-diorite. 

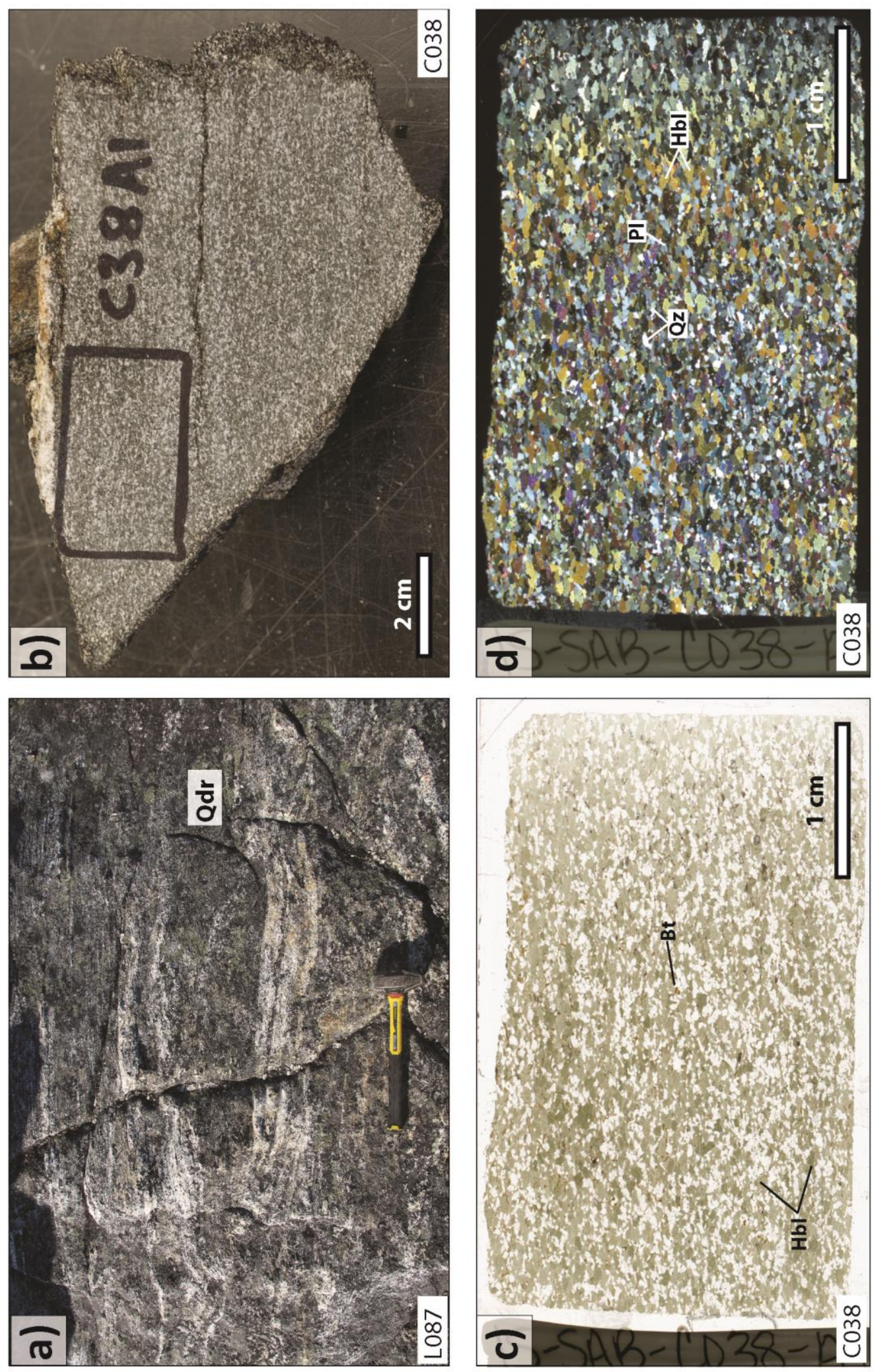
Figure 2.8. Photographs and photomicrographs, in cross-polarized light, of biotitehornblende quartzite in cover rocks of the Ptarmigan Fiord area, Hall Peninsula of Baffin Island. a) northwestward view of grey- to orange-weathering quartzite that is the basal cover unit at the contact between the 'B3' basement and the 'C3' cover rocks (note $1.8 \mathrm{~m}$ tall field assistant for scale); b) $1 \mathrm{~m}$ thick layer of blue-grey quartzite within rusty brownweathering psammitic to pelitic schists (note $1.8 \mathrm{~m}$ tall field assistant for scale); c) thin section photomicrograph of quartzite containing $5-10 \%$ biotite arranged in 1-10 mm thick continuous bands and layers, which are interpreted to represent primary bedding $\left(\mathrm{S}_{0}\right)$; d) thin section photomicrograph of quartzite grains exhibiting two distinct grain sizes (coarser 1-2 $\mathrm{mm}$ wide grains and $<1 \mathrm{~mm}$ wide grains), which are aligned in alternating parallel bands defining a foliation. Abbreviation: Bt, biotite; Psa, psammite; Qz, quartz; Qtz, quartzite. 

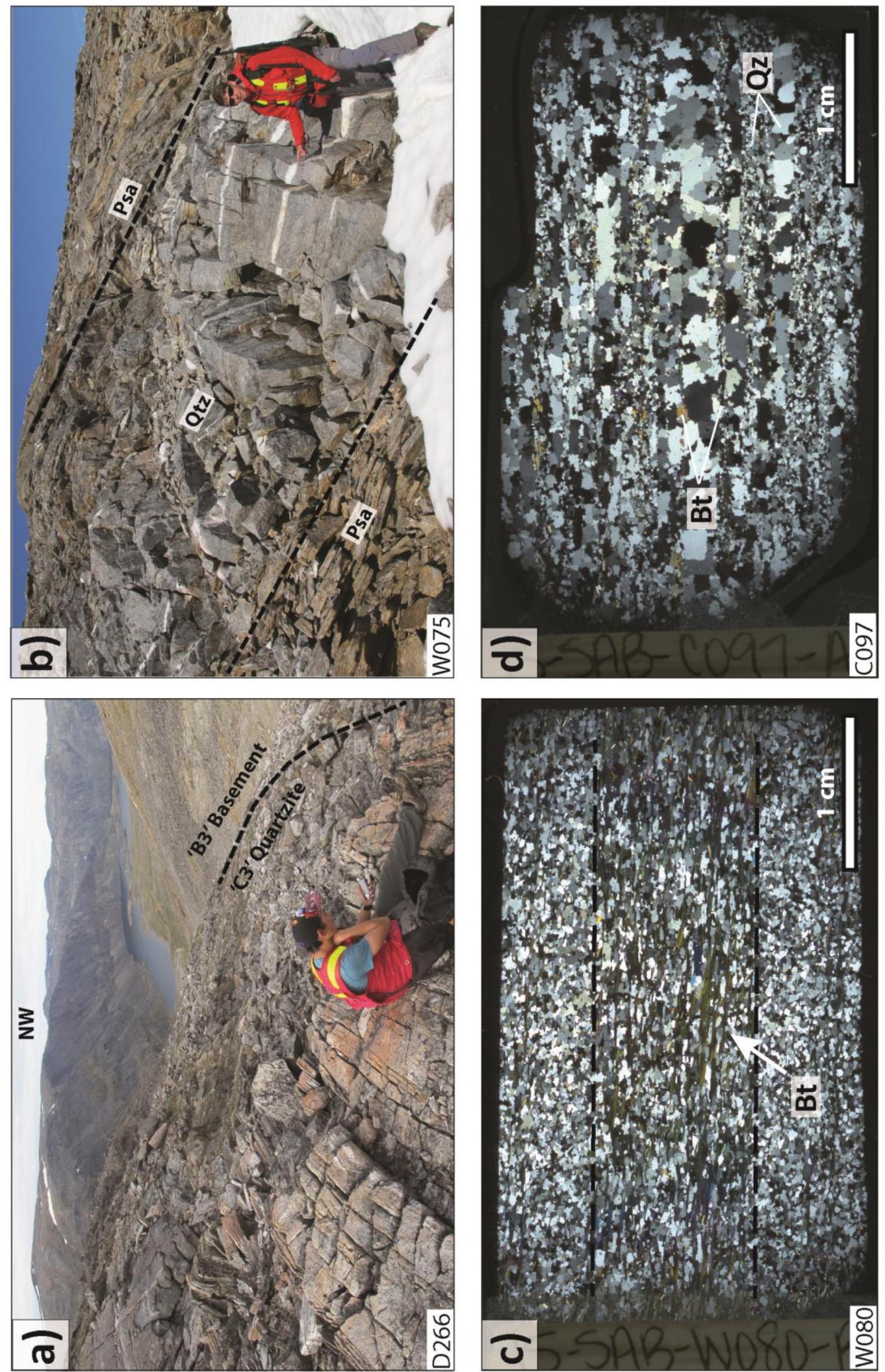
Figure 2.9. Photographs and photomicrographs, in plain-and cross-polarized light, of biotite-muscovite psammitic schist interlayered with garnet-sillimanite $\pm \mathrm{K}$-feldspar semipelitic to pelitic schist in cover rocks of the Ptarmigan Fiord area, Hall Peninsula of Baffin Island. a) northward view of thin alternating sequences $(10-50 \mathrm{~cm}$ thick $)$ of pelitic schist (Pel) and psammitic schist (Psa), which exhibit both sharp and gradational contacts. These alternating interlayers are interpreted as relict bedding, termed $\left.\mathrm{S}_{0} ; \mathbf{b}\right)$ hand specimen of pelitic schist with 1-2 cm long elongate knots $\sim 10-15 \%$ of sillimanite, quartz and $\pm \mathrm{K}$-feldspar, which define a strong stretching lineation $\left(\mathrm{L}_{2 \mathrm{a}}\right)$; c) and d) matrix of the semipelitic to pelitic schist is typically composed of $\sim 30 \%$ finegrained, equigranular, granoblastic quartz, $\sim 45 \%$ fine-to medium-grained biotite, and $10 \%$ coarse-grained, and randomly oriented secondary (?) muscovite. Abbreviations: Afs, alkali-feldspar; Bt, biotite; Ms, muscovite; Pel, pelite; Psa, psammite; Qz, quartz; Sil, sillimanite. 

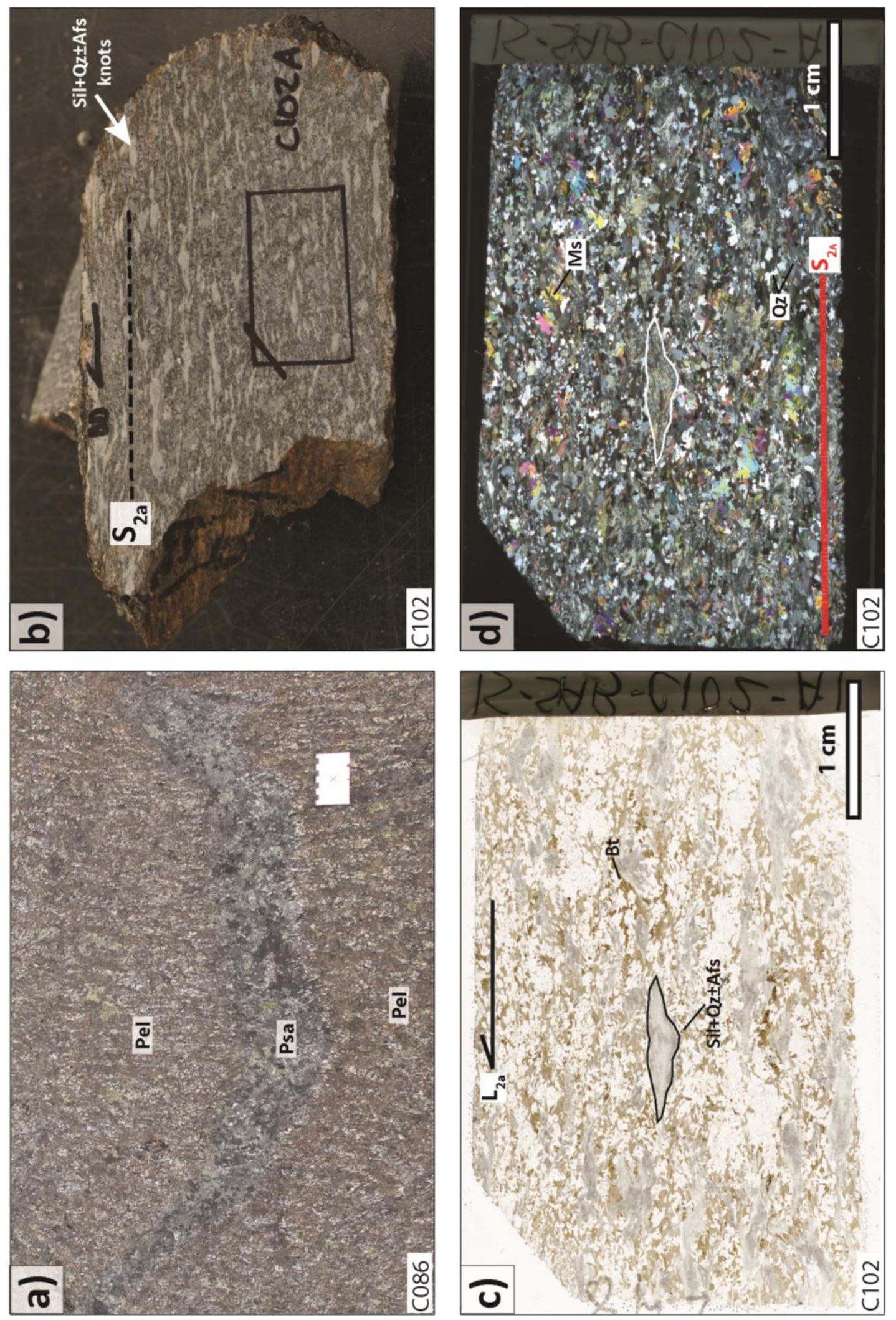
Figure 2.10. Photographs and photomicrograph, in cross-polarized light, of garnetsillimanite $\pm \mathrm{K}$-feldspar pelitic schist in cover rocks of the Ptarmigan Fiord area, Hall Peninsula of Baffin Island. a) westward view of 1-3 m thick layer of garnet-muscovitesillimanite schist studded with 5-20 mm diameter garnets. These layers are distinctive marker units; b) hand specimen collected from W078 (Map 2; back pocket) showing 1-2 cm wide garnets in micaceous matrix; c) thin section photomicrograph of W078 sample depicting coarse-grained garnet porphyroblasts within a biotite-rich matrix; d) compositional layering and foliation with concordant white- to cream-coloured leucogranite or boudinaged veins folded by outcrop-scale folds (note the $8 \mathrm{~cm}$ long scale card for scale). Abbreviations: Grt, garnet; Lg, leucogranite; Pel, pelite; Psa, psammite. 

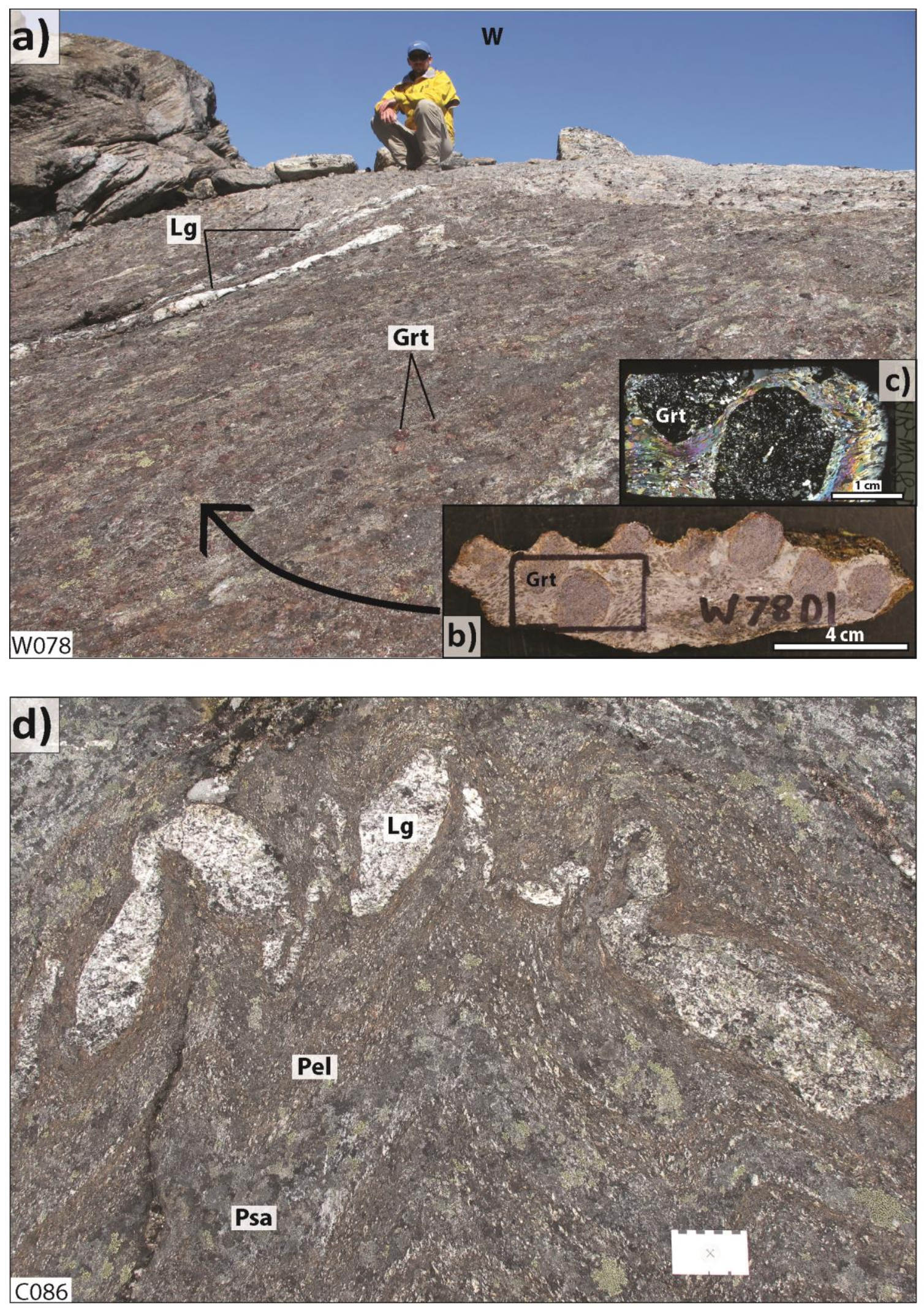
Figure 2.11. Sample photographs and photomicrograph, in plain-and cross-polarized light, of biotite-muscovite psammitic schist in cover rocks of the Ptarmigan Fiord area, Hall Peninsula of Baffin Island. a) hand specimen of light-grey weathering, fine-to medium-grained, equigranular psammitic schist. The alignment of flattened 1-4 mm long biotite grains define the trace of a strong $\mathrm{S}_{2 \mathrm{a}}$ foliation in this field of view; $\mathbf{b}$ ) same sample as previous description in a), however, with a different orientation, perpendicular to the foliation and looking down the dominant stretching lineation $\left(\mathrm{L}_{2 \mathrm{a}}\right)$, defined by quartz rods and elongate biotite grains; c) and d) thin section photomicrographs in plainand cross-polarized light of the matrix of the psammitic schist, which is dominated by $\sim 60 \%$ fine-grained, equigranular, granoblastic quartz, $\sim 10 \%$ fine-grained, equigranular feldspar (split evenly between plagioclase and K-feldspar), and 30\% fine-to coarsegrained, elongate biotite. Abbreviations: Bt, biotite; Qz, quartz. 

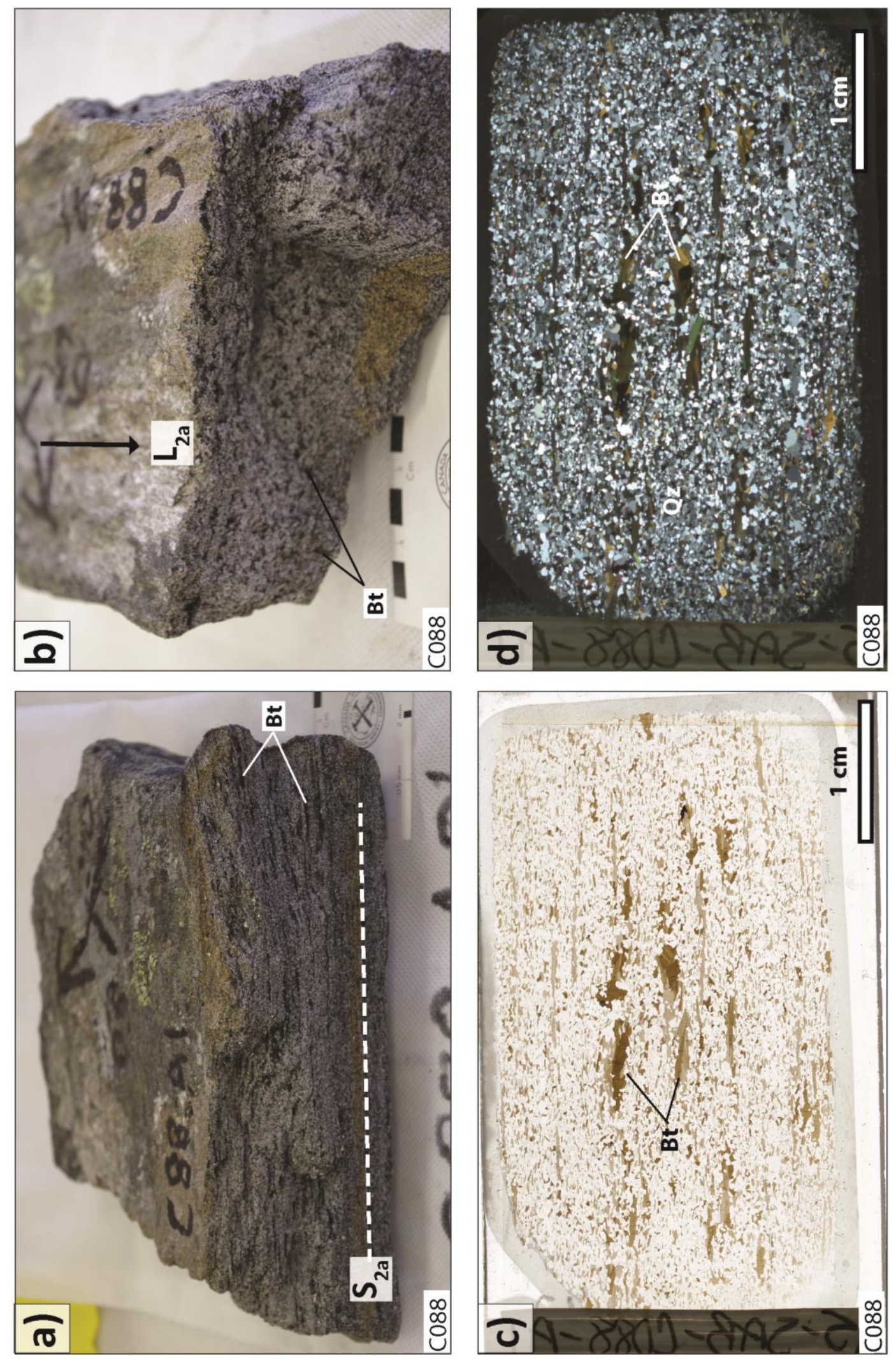
Figure 2.12. Outcrop and sample photographs, and photomicrograph, in plain-and crosspolarized light, of garnet-orthopyroxene amphibolite in cover rocks of the Ptarmigan Fiord area, Hall Peninsula of Baffin Island. a) westward view of a 2-5 m thick resistant panel of dark-grey weathering amphibolite, at the high-strain contact between ' $\mathrm{C} 3$ ' and 'B4' at station C089 (Map 2; back pocket). Outcrop weathering is controlled by a strong $\mathrm{S}_{2 \mathrm{a}}$ foliation (note the $30 \mathrm{~cm}$ long hammer for scale); b) hand sample of dark grey-green, fine-grained amphibolite with a $4-5 \mathrm{~mm}$ long orthopyroxene porphyroblast aligned parallel to a foliation defined by the alignment of flattened hornblende grains; c) and d) thin section photomicrographs of amphibolite matrix consisting typically of $\sim 50 \%$ finegrained, subhedral, flattened hornblende in a planar array, $\sim 20 \%$ fine-grained plagioclase, and $\sim 30 \%$ fine-grained, granoblastic quartz. A strong $\mathrm{S}_{2 \mathrm{a}}$ foliation is defined by the alignment of flattened hornblende. Abbreviations: Hbl, hornblende; Opx, orthopyroxene; Pl, plagioclase; Qz, quartz. 

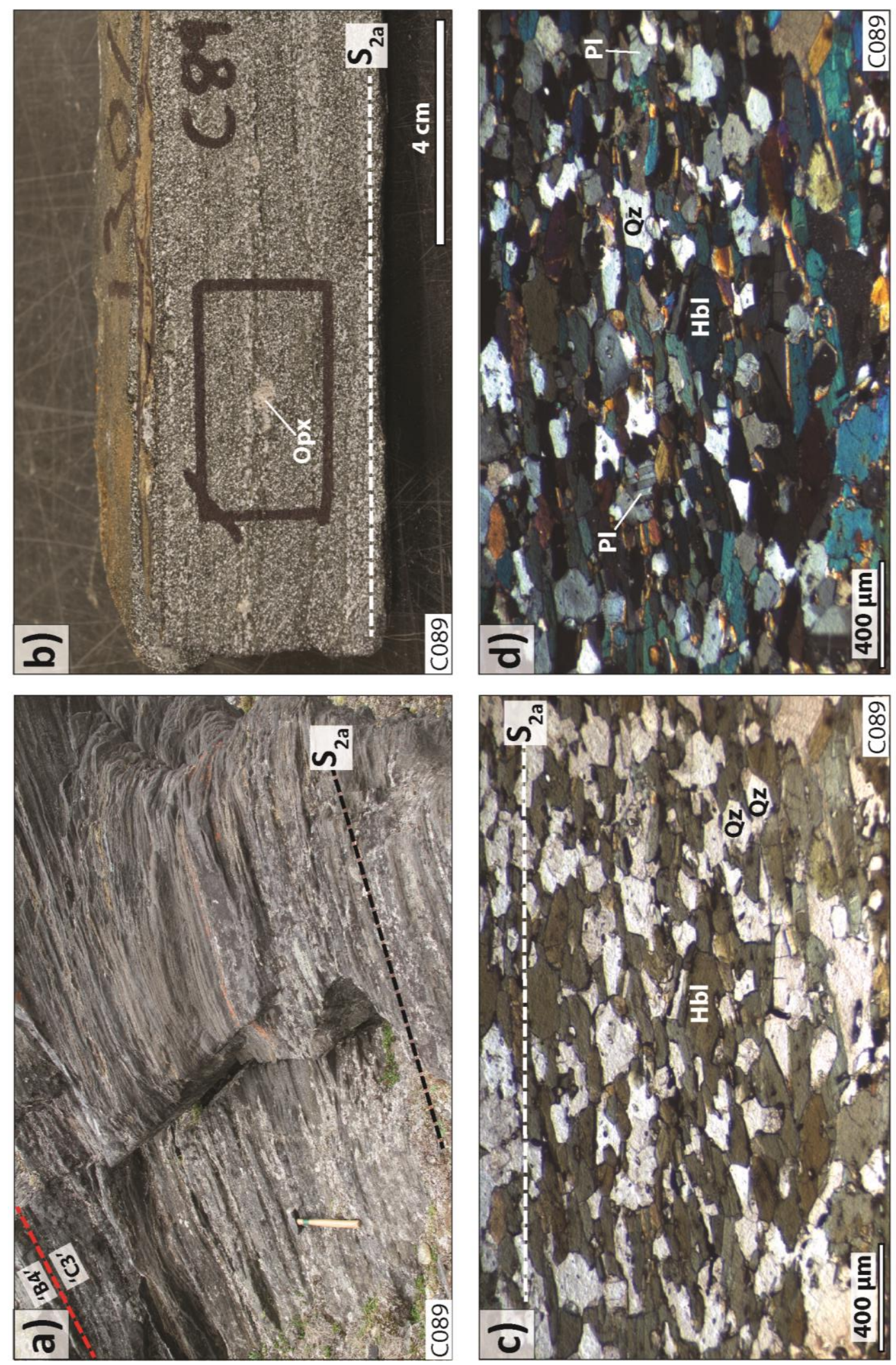
Figure 2.13. Thin section photomicrographs, in plain-and cross-polarized light, of garnetorthopyroxene amphibolite in cover rocks of the Ptarmigan Fiord area, Hall Peninsula of Baffin Island. a) and b) sample C089 (Map 2; back pocket), fine-grained amphibolite with a $4-5 \mathrm{~mm}$ long, flattened, foliation-aligned orthopyroxene porphyroblast; c) and d) sample C067 (Map 2; back pocket), fine-grained amphibolite with coarse (5 - $8 \mathrm{~mm}$ ) garnet porphyroblasts, producing a pressure shadow and trace of foliation, defined by the alignment of flattened hornblende and fine-grained biotite grains, abuts against the garnet. The garnet appears to have grown as the foliation formed, and there is minor small scale folding of foliation. Abbreviations: Bt, biotite; Grt, garnet; Hbl, hornblende; Qz, quartz. 

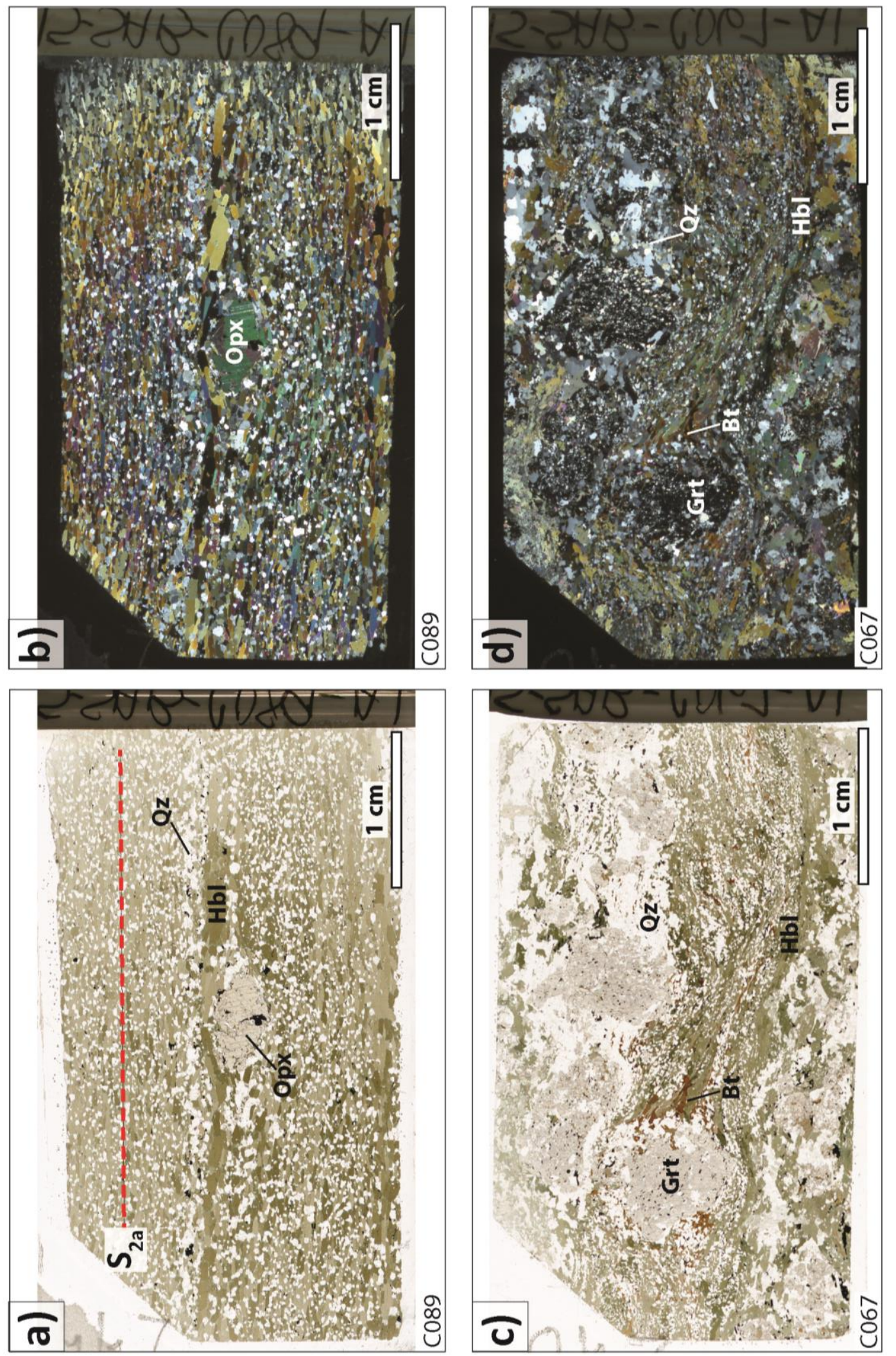
Figure 2.14. Outcrop photographs and photomicrograph, in cross-polarized light, of wollastonite-tremolite calc-silicate in cover rocks of the Ptarmigan Fiord area, Hall Peninsula of Baffin Island. a) northward view of a 2-5 $\mathrm{m}$ thick panel of fine- to mediumgrained calc-silicate with $2-5 \mathrm{~cm}$ size tremolite knots and wollastonite porphyroblasts (note $8 \mathrm{~cm}$-wide scale card); b) close-up view of a $4 \mathrm{~cm}$ long wollastonite porphyroblast within the fine-to medium-grained calc-silicate matrix (note $8 \mathrm{~cm}$-wide scale card for scale); c) thin section photomicrograph, in cross-polarized light, of the calc-silicate matrix, which is comprised of $\sim 80 \%$ carbonate minerals (dolomite and calcite) and $\sim 20$ $\%$ fine-grained tremolite. A weak foliation is defined by the long axis of fine-grained tremolite, which are arranged in parallel 2-3 mm thick bands. Abbreviations: Cal, calcite; Dol, dolomite; Tr, tremolite; Wo, wollastonite. 

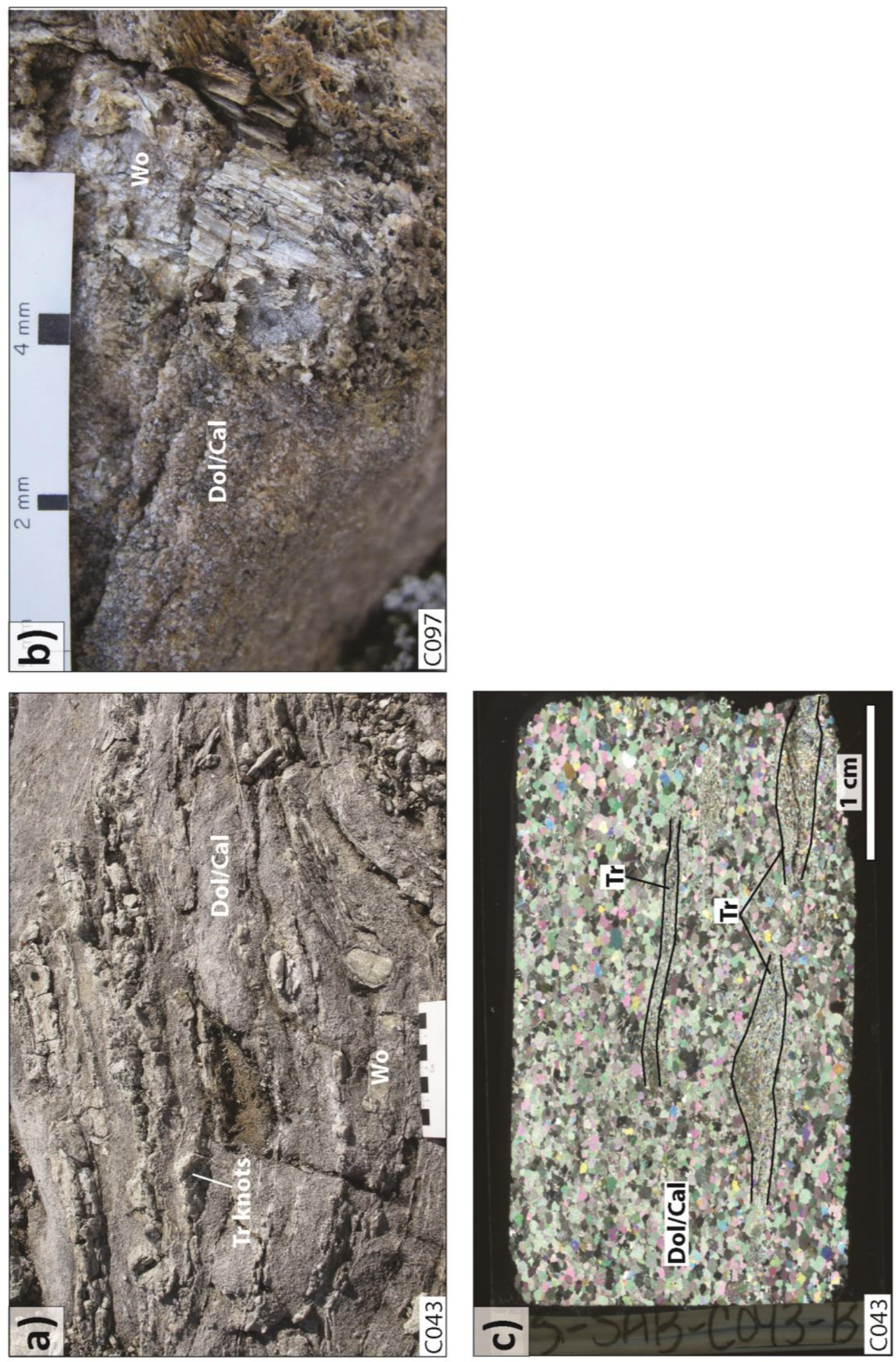
Figure 2.15. Outcrop and hand specimen photographs of weakly foliated syenogranite pluton in the basement rocks of the Ptarmigan Fiord area, Hall Peninsula of Baffin Island. a) northward view of a weakly foliated syenogranite lens that crosscuts gneissic foliation in basement; b) northward view of an outcrop of massive- to weakly-foliated syenogranite that crosscuts basement gneiss (sample location of geochronology sample C117, Map 2; back pocket); c) hand specimen from station C117 (Map 2; back pocket) with a foliation defined by the alignment of 1-2 mm thick biotite-rich bands. Abbreviations: Afs, alkali-feldspar; Bt, biotite; Pl, plagioclase; Qz, quartz; Syeno, syenogranite. 

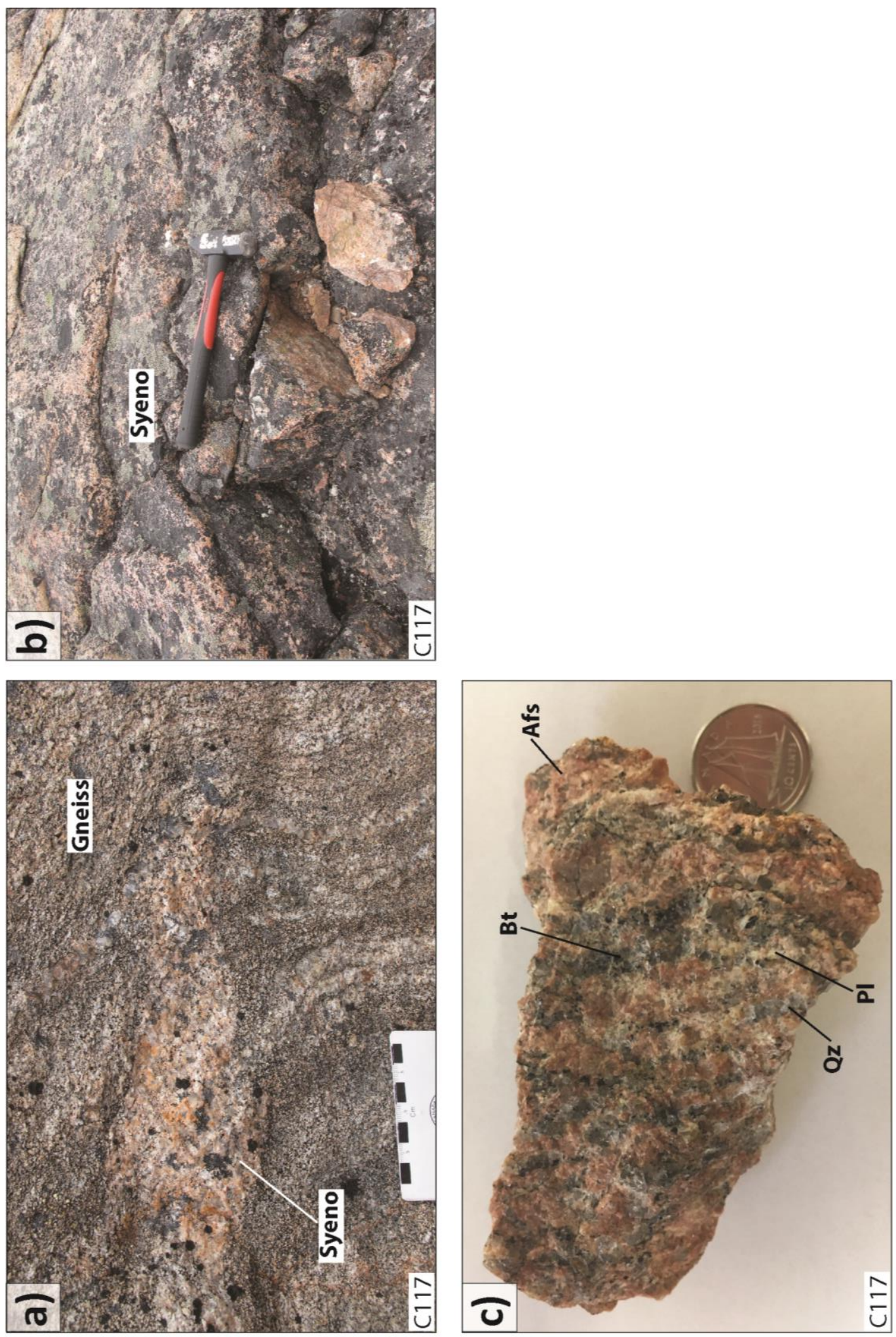
Table 2.1: Comparison of basement units of the Ptarmigan Fiord area and the From et al. (2014) study area. Scott (1999) dated three separate granitic dykes that cross cut gneiss along eastern Hall Peninsula, using U-Pb zircon geochronology and isotope dilutionthermal ionization mass spectrometry (ID-TIMS). Zircon data yielded ages of $2835 \pm 11$ Ma, $2768 \pm 13 \mathrm{Ma}$, and $2820 \pm 5 \mathrm{Ma}$ respectively. Titanite ages from the same samples returned much younger ages, between ca. 1730 and 1842 Ma. Consequently, Archean zircon from these intrusions are either interpreted as crystallization ages representing emplacement of the dykes, or are inherited as xenocrysts within Paleoproterozoic granitic dykes. 


\begin{tabular}{|c|c|c|c|c|}
\hline $\begin{array}{l}\text { Ptarmigan } \\
\text { Fiord Units }\end{array}$ & From et al. (2014) units & Basis for comparison * & $\begin{array}{l}207 \mathrm{~Pb} / 206 \mathrm{~Pb} \\
* * \text { ages of } \\
\text { Ptarmigan } \\
\text { Fiord units } \\
\text { (Ma) }\end{array}$ & $\begin{array}{l}207 \mathrm{~Pb} / 206 \mathrm{~Pb} \\
* * \text { ages of } \\
\text { From et al. } \\
(2014) \\
\text { units (Ma) }\end{array}$ \\
\hline $\begin{array}{l}\text { Unit 1a: } \\
\text { 士orthopyroxen } \\
\text { e-hornblende- } \\
\text { bearing biotite } \\
\text { granodiorite }\end{array}$ & $\begin{array}{l}\text { Leopard gneiss' (Unit 3): } \\
\text { megacrystic granodiorite } \\
\text { gneiss }\end{array}$ & $\begin{array}{l}\text { - Overall granodioritic } \\
\text { composition } \\
\text { - Similar outcrop textures } \\
\text { - However, grain size and } \\
\text { accessory minerals do not } \\
\text { correlate between units }\end{array}$ & NA & $2928 \pm 5$ \\
\hline $\begin{array}{l}\text { Unit 1b: } \\
\text { hornblende- } \\
\text { biotite } \\
\text { monzogranite }\end{array}$ & $\begin{array}{l}\text { Porphyroclastic } \\
\text { monzogranite gneiss } \\
\text { (Unit 7): biotite- } \\
\text { hornblende-epidote- } \\
\text { bearing monzogranite }\end{array}$ & $\begin{array}{l}\text { - Overall monzogranitic } \\
\text { composition } \\
\text { - Similar outcrop textures } \\
\text { and abundance of mafic } \\
\text { enclaves (of similar } \\
\text { composition) }\end{array}$ & $2719 \pm 4$ & $2720 \pm 5$ \\
\hline $\begin{array}{l}\text { Unit 1c: } \\
\text { hornblende- } \\
\text { biotite- } \\
\text { bearing- } \\
\text { gneissic } \\
\text { tonalite }\end{array}$ & $\begin{array}{l}\text { Grey tonalite gneiss (Unit } \\
\text { 2): biotite-hornblende- } \\
\text { bearing tonalite }\end{array}$ & $\begin{array}{l}\text { - Overall tonalitic } \\
\text { composition } \\
\text { - Similar outcrop textures } \\
\text { and accessory minerals }\end{array}$ & NA & $2810 \pm 3$ \\
\hline $\begin{array}{l}\text { Unit 1d: } \\
\text { biotite- } \\
\text { hornblende- } \\
\text { rich quartz- } \\
\text { diorite to } \\
\text { gabbro }\end{array}$ & $\begin{array}{l}\text { Pyroxene diorite (Unit 1): } \\
\text { clinopyrexene } \pm \text { orthopyro } \\
\text { xene-bearing diorite }\end{array}$ & $\begin{array}{l}\text { - Overall quartz diorite to } \\
\text { dioritic composition } \\
\text { - Similar outcrop textures } \\
\text { and occurrence as } \\
\text { deformed xenoliths } \\
\text { within other basement } \\
\text { rocks } \\
\text {-However, different } \\
\text { accessory minerals }\end{array}$ & NA & $2700 \pm 3$ \\
\hline $\begin{array}{l}\text { Unit 3: biotite } \\
\text { syenogranite }\end{array}$ & $\begin{array}{l}\text { Syenogranite (Unit } 8) \text { : } \\
\text { syenogranite veins that } \\
\text { crosscut all rock units }\end{array}$ & $\begin{array}{l}\text { - Overall syenogranitic } \\
\text { composition } \\
\text { - Same crosscutting } \\
\text { relation with respect to } \\
\text { other basement units } \\
\text { - similar medium-grained } \\
\text { to pegmatitic grain size }\end{array}$ & $1860 \pm x$ & NA \\
\hline
\end{tabular}

* Refer to From et al. (2014) for detailed descriptions and photographs of their units.

**Sensitive High Resolution Ion Micro Probe (SHRIMP) U-Pb zircon ages. See From et al. (2015), Rayner (2015), and for methods and interpretation. 


\section{CHAPTER 3 - STRUCTURAL HISTORY, STRAIN ANALYSIS, AND KINEMATICS OF POLYPHASE DEFORMATION IN THE PTARMIGAN FIORD AREA}




\subsection{Introduction}

The Ptarmigan Fiord study area (Map 1; back pocket) is dominated by a map pattern of repeated couplets of Archean basement and Paleoproterozoic cover rocks. The disposition and orientation of these couplets are the result of at least three generations of structures (summarized in Table 3.1). The focus of this chapter is the Paleoproterozoic structural history, which controls the orientation of basement-cover contacts and the map pattern of the Ptarmigan Fiord map area. This was accomplished by:

i. Evaluating structures throughout the map area; establishing structural domains; and characterizing the orientation, geometry and succession of structures in each domain;

ii. Evaluating kinematic indicators and strain gradients at basement-cover contacts, highly strained zones and domain boundaries;

iii. Determining the structural history of the map area.

\subsection{Methods}

Seven days of bedrock mapping and sampling were carried out at 1:40 000 scale in the $\sim 190 \mathrm{~km}^{-2}$ Ptarmigan Fiord area, during the summer of 2015. The fieldwork was conducted from a remote field camp located on the McKeand River (Blue Dot, Figure A, Map 1; back pocket) by three mapping teams, and included 18 helicopter supported ground traverses, resulting in 343 ground geological stations. Understanding the nature and geometry of basement-cover contacts was a priority during the field work, and dictated the placement of ground traverses. Priority was given to mapping in the 
southeast and northwest domains due to the greater abundance of cover rock as compared to the northern and southern domains (Figure F, Map 1; back pocket). Therefore, a much higher degree of certainty is attributed to the map patterns and structural interpretations in the southeast and northwest domains, compared to the other two domains.

Field data are depicted on Map 1 (back pocket): black foliation symbols represent the distribution of 2015 mapping data, and grey foliation symbols represent the distribution of legacy data collected on three ground traverses by the Canada Nunavut Geoscience Office in 2013. Field data include lithological and structural observations, outcrop photographs, oriented samples for petrography and microstructural work, and orientation measurements collected by the author and other mappers working on the GEM-2 regional mapping project. Petrographic and microstructural data were collected from oriented thin sections, using a polarized light microscope. Manipulation of geospatial data and compilation of the geological map was conducted using ArcMap 10.2.2 Geographic Information System (GIS) computer software. The final map (Map 1; back pocket) was compiled on the basis of consistency with field data, field photographs, air photographs and satellite images, with consideration for effects of topography on the trace of map unit contacts.

Analysis of fold geometry was carried out within each of the four structural domains. In order to sort out the effects of superposed folds, each domain was further divided into subdomains to isolate segments of folds with generally consistent orientations, and the orientation and geometry of folds within each subdomain was assessed at two scales. Firstly, in structural subdomains at the scale of $500-1000 \mathrm{~m}$, representative contact orientations from the fold limbs and hinges, determined from the 
structure contours of map unit contacts, were used to determine fold geometry and orientation at the map scale (i.e. red foliation orientations on Map 1; back pocket, and Appendix A). Secondly, field measurements of foliation orientations, from each subdomain, were plotted on stereograms and compared with the domain-scale structures in order to screen out the effects of superposed folds, and to determine fold orientation of mesoscopic folds related to the domain-scale structure. The orientation and geometric data of map-scale folds were then integrated with oriented photographs and annotated sketches of outcrop- and hand-specimen-scale folds to produce the final descriptions of the different generations of fold structures.

Equal area stereograms were plotted using the open source program 'Stereonet' (v.9.5.1), which incorporates algorithms from Allmendinger et al. (2012) and Cardoza and Allmendinger (2012; see Appendix B for more details). Statistical analyses (i.e. Fisher Vector Distribution) were used to calculate the mean vectors for planar orientations, and to find the best fit great circles (i.e. Bingham Axial Distribution) for pigirdles and axial surfaces of folds. A brief summary of the background theory for statistical analyses and appropriate references are presented in Appendix C.

A qualitative, comparative strain analysis was conducted on oriented samples of basement rock located at the upper and lower contacts of the basement - cover couplets within the study area, based on grain size and shape, and fabric elements (i.e. presence of an S-C fabric, strength of foliation and lineation, etc.). A preliminary kinematic analysis was conducted on oriented basement and cover samples and field photographs that contain visible stretching lineations and kinematic indicators. Both analyses were conducted to help characterize the nature and origin of the repeated basement-cover 
contacts. These analyses were aided using scans of oriented thin sections prepared under plane and cross-polarized light.

A structural cross-section and a diagrammatic block diagram were generated to depict the geometry of the map area, including major folds and ductile shear zones (with shear senses indicated), and a structural history was interpreted. Cross-section views in the block diagram were constructed perpendicular to map-scale folds to depict the geometry of the folded map units in each domain. In some areas, a lack of continuity or omissions in folded layers or structures were identified from place to place, requiring the map and block diagram to be modified. For example, the northern and southern structural domains were introduced to reconcile the extent and lack of marker continuity revealed in the map pattern and block diagram.

\subsection{Naming conventions for structures of the Ptarmigan Fiord area}

Based on the multi-scale structural analysis, described above, for the Paleoproterozoic structures in the area (i.e. structures that deformed the cover rocks as well as the Archean basement), successive generations of structures are described for the map area in the following sections and presented in Table 3.1. Archean deformation events are termed $\left(D_{A}\right)$, and Paleoproterozoic deformation events are termed $\left(D_{P}\right)$. This project focuses on the Proterozoic structures, which are apparently penetrative throughout the area, and generally overprint the Archean structures. For the sake of simplicity in naming and labeling Proterozoic structures, "P" subscripts are omitted from the Paleoproterozoic structure names, with the exception of $\mathrm{T}_{\mathrm{P}}$, a generation of 
Paleoproterozoic fault or shear zone of uncertain generation. The relative generations of structures, determined from overprinting or crosscutting relationships, are ordered numerically and designated with an appropriate numeric subscript in the structure name (e.g. second generation Paleoproterozoic DP2 structures, such as $F_{2 a}$, are older than third generation $\mathrm{D}_{\mathrm{P} 3}$ structures, such as $\mathrm{F}_{3 \mathrm{a}}$ ). Because the presence or absence of particular generations of structures varies from domain to domain, and the correlation of structures between domains is uncertain, domain designations are included in the structure generation naming hierarchy (e.g. in naming and labeling structures from the northwest and southeast domains, "(NW)" and "(SE)" subscripts are used accordingly). Structures with the same apparent geometry, relationship to metamorphism, structural style and characteristics, may occur in more than one domain but with different orientations in different domains. Although such structures may be assigned to the same generation designation (e.g. $\left.F_{2 b}\right)$, this does not imply correlation of structures from domain to domain.

The four structural domains in the study area each have a characteristic structural style and unique map pattern. For example, the southeast domain is characterized by a bent, upright $\mathrm{F}_{2 \mathrm{~b}}$ (SE) syncline, whereas the northwest domain is a folded panel of gently to moderately NW-dipping rocks. The level of confidence about the structural style of each domain is largely based on the density of field stations. For example, the structural style of the northern and southern domains, dominated by basement with few cover marker units, is uncertain due to the limited amount of targeted mapping in those areas, compared to the southeast and northwest domains that were the focus of 2015 fieldwork 
(inside red dashed lines, Figure F, Map 1; back pocket). Therefore, the bulk of the structural descriptions in this chapter, focus on the southeast and northwest domains.

Within all four domains, there are intercalated basement and cover rocks in varying proportions. Although rocks in all four domains are variably deformed, all of the basement and cover rocks have apparently experienced a major DP2 tectonothermal event with penetrative deformation (e.g. foliations, folds, and lineations) that occurred under conditions of amphibolite facies metamorphism, and in part, anatexis. During this event, pre-existing layering and structures (e.g. compositional layering, dykes, foliations, lineations, or mature folds) were transposed into concordance with syntectonic DP2 structures during a significant transposition event ( $\left.\mathrm{D}_{\mathrm{P} 2}\right)$. Rocks at any given place may contain structures that formed progressively over time and have the same end geometry and orientation. Also, apparently similar structures from place to place or domain to domain, may or may not have formed at different times. Therefore the convention for naming the suite of transposed structures and subsequent generations of structures that have deformed the transposed structures is modified after Spalla et al. (2011, and references therein). In this naming scheme, concordant pre- and syntectonic foliations are all named $\mathrm{S}_{2 \mathrm{a}}$. It is understood that $\mathrm{S}_{2 \mathrm{a}}$ is a composite foliation ( $\mathrm{S}_{1-2 \mathrm{a}}$ ) that may contain concordant structures of one or more generations (i.e. pre-DP2 structures that have been transposed as well as syn- $\mathrm{D}_{\mathrm{P} 2}$ structures termed $\mathrm{D}_{\mathrm{P} 2}$.) Similarly, "mature" or early $\mathrm{D}_{\mathrm{P} 2}$ folds as well as syn-peak $F_{2 a}$ folds are termed $F_{2 a}$. In other words, it is understood that there may be one or more generations of $\mathrm{D}_{\mathrm{P} 2}$ folds included in the fold generation termed $F_{2 a}$. Folds that have folded the main $D_{P 2}$ foliation, $S_{2 a}$ and $F_{2 a}$, folds are termed 
"immature" folds, and are named numerically according to generation $\mathrm{F}_{2 \mathrm{~b}}, \mathrm{~F}_{3 \mathrm{a}}$, etc. Similarly, $\mathrm{L}_{2 \mathrm{a}}$ is understood to represent pre- or syn-Dp2 lineations (Figure 3.1a).

In this thesis, the lower boundaries of the basement sheets in the basement-cover couplets (e.g. B1 + C1, B2 + C2, etc., Map 1; back pocket), are considered as Paleoproterozoic structural boundaries, likely brittle or discrete ductile thrusts, that resulted in the repetition and stacking of the basement-cover sheets (discussed in Section 3.5.1). The timing and nature of the thrusts are uncertain, since they may be either premetamorphic brittle thrust faults or syn-metamorphic ductile shear zones, and they have likely been reactivated under ductile conditions during the main $\mathrm{D}_{\mathrm{P} 2}$ tectonothermal event. The inferred structures at the base of every basement-cover couplet are named and labelled as $T_{P}$ (i.e. brittle or ductile thrust fault of uncertain generation, where subscript "P" is for Paleoproterozoic), for the purposes of describing and discussing them.

\subsection{Archean structures}

Because one of the objectives of this study is characterizing and understanding the structures controlling the orientation of basement-cover contacts, which are necessarily younger than the Paleoproterozoic depositional age of the cover rocks, the Archean deformation $\left(\mathrm{D}_{\mathrm{A}}\right)$ and associated structures, are briefly described in this section although descriptions are based on limited field observations.

Distinguishing Archean structures from Paleoproterozoic structures in basement units is challenging, and may be impossible to do in the field, especially in domains where basement rock is dominant or where cover rocks, which would host structures 
useful for reference or comparison to those in Archean structures, are absent. In areas where both basement and cover rocks were deformed together and structures in basement and cover are concordant, it is possible to argue that the structures are necessarily Paleoproterozoic in age (see discussion in section 3.5). Potential Archean primary and deformation structures in the basement rocks are interpreted to be relict structures that have been preserved despite the penetrative Paleoproterozoic overprint. These include compositional layering, contacts between basement marker units, and contacts between mafic boudins, interpreted as intrusive contacts (From et al., 2015). In the case of boudinaged mafic rocks, it is uncertain whether boudinage is Archean or Paleoproterozoic. Further detailed mapping in the basement complex would be required to identify any relict Archean structural history that may be preserved within a region that has apparently been penetratively overprinted in the Paleoproterozoic.

\subsection{Paleoproterozoic structures}

The purpose of this section is to introduce and describe the Paleoproterozoic structures (i.e. structures that affect the both the Paleoproterozoic cover and the Archean basement rocks), summarized in Table 3.1. The nature of basement-cover contacts is described first, followed by descriptions of structures related to the major tectonothermal event ( $\mathrm{D}_{\mathrm{P} 2}$ ), and post-thermal peak events (i.e. $\mathrm{D}_{\mathrm{P} 3}$ and $\left.\mathrm{D}_{\mathrm{P} 4}\right)$. 


\subsubsection{Nature of basement-cover couplets}

Map-scale repetition and stacking of basement-cover couplets (i.e. 'B1' + 'C1', 'B2' + 'C2', etc., Map 1; back pocket) occur primarily in the southeast and northwest domains (Figure 2.2a-b). The basal contacts of basement in basement-cover couplets are interpreted as structural contacts $\left(\mathrm{T}_{\mathrm{P}}\right.$; Table 3.1); whereas the upper basement contacts with cover are interpreted as non-conformable or reworked non-conformable contacts, as suggested by Steenkamp and St-Onge (2014), Chadwick et al. (2016), and Skipton et al. (2016). The 'older over younger' relationship at the base of each basement-cover couplet, where Archean basement rock overlies Paleoproterozoic cover rock, is a hallmark of thrust tectonics.

The structure $\mathrm{T}_{\mathrm{P}}$ could represent brittle or discrete ductile thrust faults that preceded transposition and ductile reworking during the main tectonothermal event DP2. Alternatively, $\mathrm{T}_{\mathrm{P}}$ may have formed during the main tectonothermal event either as ductile shear zones or in response to imbrication under conditions of mid-crustal flow and nappe development. There are localized, syn-Dp2 5-10 m thick shear zones in basement rocks, some of which overprint $\mathrm{T}_{\mathrm{P}}$ at the basal basement contact of the basement-cover couplets. Because these shear zones also occur within basement slices and at upper contacts of basement slices they may not have been responsible for the repetition of basement-cover couplets, and may reflect strain localization during $\mathrm{D}_{\mathrm{P} 2}$. The question as to timing and structural style of $\mathrm{T}_{\mathrm{P}}$ in the Ptarmigan Fiord area is introduced in Section 3.5.2.1, and a discussion about potential tectonic processes and the crustal level at which $\mathrm{T}_{\mathrm{P}}$ formed is presented in Chapter 4. 


\subsubsection{Structures related to the major tectonothermal event (DP2)}

The purpose of this section is to provide descriptions of synmetamorphic transposition structures that formed during the major progressive tectonothermal event termed $\mathrm{D}_{\mathrm{P} 2}$. Structural elements described include: transposition foliation with local 5-10 $m$ thick shear zones of annealed mylonite $\left(\mathrm{S}_{2 \mathrm{a}}\right)$, lineation $\left(\mathrm{L}_{2 \mathrm{a}}\right)$, intrafolial or mature folds $\left(\mathrm{F}_{2 \mathrm{a}}\right)$, immature folds $\left(\mathrm{F}_{2 \mathrm{~b}}\right)$, and post-transposition foliation $\left(\mathrm{S}_{2 \mathrm{~b}}\right)$, as summarized in Table 3.1. Transposition is the formation of structures, such as foliation, lineation or folds, by progressive superposition of reference surfaces (e.g. $\mathrm{S}_{0}, \mathrm{~S}_{1}, \mathrm{~S}_{\mathrm{n}}$, etc.) due to rotational strain (Passchier and Trouw, 2005; and references therein), and may be accompanied by formation of new structures. In other words, older structures may be transposed into concordance with each other and with younger structures that formed during a strong overprinting deformation event (Passchier and Trouw, 2005). A compound transposition foliation may result from a superposition of a tectonic foliation on an earlier tectonic foliation or compositional layering (Twiss and Moores, 2007; and references therein). Depending on the initial orientation of a folded marker layer with respect to the strain ellipsoid, the layer may become isoclinally folded and dismembered, so that the folds are recognized only as rootless folds, which are isolated isoclinal fold hinges that have axial surfaces parallel to the foliation and are not connected to any other hinges (Figure 3.1b; Turner and Weiss, 1963; Twiss and Moores, 2007). However, folding is not always involved during transposition, and earlier layering may rotate into a discontinuous banding parallel to the new foliation (Twiss and Moores, 2007). 


\subsubsection{Transposition foliation and shear zones $\left(S_{2 a}\right)$}

Within the southeast and northwest domains, a penetrative transposition foliation $\mathrm{S}_{2 \mathrm{a}}$ is well developed in all basement and cover rocks involved in map-scale basementcover couplets. In the adjacent northern and southern domains, $\mathrm{S}_{2 \mathrm{a}}$ is interpreted to exist on the basis of limited data. In cover rocks, $\mathrm{S}_{2 \mathrm{a}}$ is defined by the alignment of compositional layering at varying scales (i.e. contacts between interlayered units, Figure 2.8b), boudinaged amphibolite and quartz layers, thermal-peak amphibolite facies minerals, voluminous 2-60 cm thick concordant leucosome pods and veins, and alternating resistant and recessive layers in weathered amphibolite outcrops (Figures 3.2a-d, 2.10b). Cm- to m-thick compositional layering, best defined in metasedimentary cover sequences by alternating $\sim 10-100 \mathrm{~cm}$ thick layers of psammitic and semipelitic to pelitic schist (Figure 2.9a), are interpreted as transposed bedding $\left(\mathrm{S}_{0}\right)$. The thickness of individual layers is commonly heterogeneous over short distances, and layers are commonly pinched out, or in some cases are truncated by other rock types along m-scale shear zones near and within $\mathrm{T}_{\mathrm{P}}$ and upper non-conformable contacts. In basement rocks, $\mathrm{S}_{2 \mathrm{a}}$ is defined by the alignment of inferred intrusive contacts (Figure 2.3c), gneissic banding (Figure 2.3b), well-developed biotite cleavage (Figure 2.4a), and boudinaged mafic layers (Figure 2.4c).

$\mathrm{S}_{2 \mathrm{a}}$, throughout the sheets of basement-cover rocks is concordant with $\mathrm{T}_{\mathrm{P}}$ and the upper non-conformable contact of repeated basement-cover couplets. There are typically localized annealed shear zones (Section 3.8.1), manifested at and parallel to the lower and upper boundaries of basement sheets, as well as within imbricated sheets of basement, that are aligned parallel to $\mathrm{S}_{2 \mathrm{a}}$. Therefore, the shear zones, with associated mylonite in 
high strain cases, are interpreted to be higher strain equivalents of $S_{2 a}$. Strain gradients, and classification of the 'background' $\mathrm{S}_{2 \mathrm{a}}$ foliation required to make the interpretation of a strain gradient, is outlined in Section 3.8.1. Unless otherwise specified, an $\mathrm{S}_{2 \mathrm{a}}$ foliation referred to in the text is a 'background' foliation, while higher strained equivalents of $\mathrm{S}_{2 \mathrm{a}}$ are referred to as shear zones (i.e. with mylonite, if mylonites are present) within the text.

The alignment of peak-temperature mineral assemblages (Chapters 1 \& 2) and leucosome within the $\mathrm{S}_{2 \mathrm{a}}$ foliation, in both basement and cover rocks, indicates that peak regional amphibolite facies metamorphism and anatexis was synchronous with $\mathrm{D}_{\mathrm{P} 2}$ deformation (Figures $2.9 \mathrm{~b}-\mathrm{d}, 2.10 \mathrm{~b}$ ). Based on the alignment of $\mathrm{T}_{\mathrm{P}}$ and the upper nonconformable contact with the $\mathrm{S}_{2 \mathrm{a}}$ foliation, imbrication of basement and cover is believed to be pre-syn-Dp2. The discrete shear zones, interpreted as higher strain equivalents of $\mathrm{S}_{2 \mathrm{a}}$, may have manifested along pre-existing discontinuities in the rocks (i.e. $\mathrm{T}_{\mathrm{P}}$, upper non-conformable contact, $\mathrm{S}_{\mathrm{A}}, \mathrm{S}_{0}$, etc.), or be the result of rheological contrasts in the rock during $\mathrm{D}_{\mathrm{P} 2}$ shearing.

\subsubsection{Lineation $\left(L_{2 a}\right)$}

Well-developed stretching lineations ( $\mathrm{L}_{2 \mathrm{a}}$, Table 3.1) are defined by the alignment of elongate faserkiesel knots within pelitic to psammitic cover rocks (Figure 2.9b-d, Figure 3.3a), hornblende in amphibolite (Figures 2.12c-d), and elongate quartz and feldspar grains or aggregates of grains within quartzofeldspathic basement and cover rocks (Figure 2.4b, 3.3b). Although the orientation of $\mathrm{L}_{2 \mathrm{a}}$ varies throughout the study area, it typically has a shallow-to-moderate plunge that trends between southwest and northwest, with rare plunge reversals to the east and southeast (Figure 3.4). Variations in 
orientation of $\mathrm{L}_{2 \mathrm{a}}$ are generally caused by overprinting fold structures such as $\mathrm{F}_{3 \mathrm{a}}$ and $\mathrm{F}_{3 \mathrm{~b}}$ folds (discussed in Section 3.5.3). This is also evidenced by faserkiesel knots that are gently folded (Figure 2.9b). The lineation is interpreted as a DP2 generation structure based on: 1) alignment of peak-temperature metamorphic minerals such as sillimanite, Kfeldspar and quartz (faserkiesel knots) in metasedimentary cover rocks; 2) alignment within $\mathrm{S}_{2 \mathrm{a}}$ foliation; 3 ) and variability of $\mathrm{L}_{2 \mathrm{a}}$ orientation, suggesting the lineations are older than immature folds $\left(\mathrm{F}_{2 \mathrm{~b}}\right)$ and post- $\mathrm{D}_{\mathrm{P} 2}$ structures (only valid because the foliations, with the lineation, are also folded by post-D 2 2 structures).

\subsubsection{Mature $D_{P 2}$ folds $\left(F_{2 a}\right)$}

Mature $F_{2 a}$ folds (i.e. folds that predated or formed at the same time as the transposition foliation) occur in both cover and basement rocks as intrafolial rootless isoclinal folds that fold compositional layering $\left(\mathrm{S}_{0}\right)$ and gneissic banding $\left(\mathrm{S}_{\mathrm{A}}\right)$ and have been transposed into concordance with the main foliation $\left(\mathrm{S}_{2 \mathrm{a}}\right)$ or tight folds with $\mathrm{S}_{2 \mathrm{a}}$ foliation concordant with the axial surfaces of the folds (Figure 3.3c-d). $F_{2 a}$ axial surfaces are aligned parallel to $S_{2 \mathrm{a}}$ and hinges are oriented parallel to the penetrative extension lineation $\left(\mathrm{L}_{2 \mathrm{a}}\right.$; Figure 3.3c-d). In the northwest domain, intrafolial sheath folds are defined by quartzofeldspathic veins and, in cover rocks, by compositional layering (Figure 3.5a). Sheath folds form under conditions of higher strain or undergo deformation for a longer period of time relative to asymmetric rootless folds (Minnigh, 1979). Sheath folds were mapped only in the northwest domain, and may provide evidence for higher strain deformation in the northwest domain compared to the other domains (see further discussion in Section 3.8.1). Since early formed folds have been, at least in part, 
reoriented during non-coaxial flow related to transposition, they are referred to as $\mathrm{D}_{\mathrm{P} 2}$ structures, whilst recognizing that they may have developed during an earlier deformation event and were subsequently modified during $\mathrm{D}_{\mathrm{P} 2}$.

\subsubsection{Immature $F_{2 b}(S E)$ folds in the southeast domain}

In the southeast domain, $\mathrm{F}_{2 \mathrm{~b}}$ (SE) immature folds occur at a range of scales from map scale (Map 1; back pocket), to $300-600$ m-high cliffs (Figure 2.2a-b) and outcrop scale (Figure 3.5b-c). The $\mathrm{F}_{2 \mathrm{~b}}$ (SE) folds deformed older mature $\mathrm{F}_{2 \mathrm{a}}$ folds, $\mathrm{S}_{2 \mathrm{a}}$ foliation, and structurally imbricated basement and cover.

$\mathrm{F}_{2 \mathrm{~b}}$ (SE) immature folds in the southeast domain (Map 1; back pocket) are typically parallel, cylindrical, asymmetric, close to open, upright to steeply inclined, generally steeply SW-dipping folds that plunge gently to moderately to the SE or NW (Figures 3.5b-d, 3.6, Figure H, Map 1; back pocket). The $\mathrm{F}_{2 \mathrm{~b}}$ (SE) map-scale folds are classified as 'major' and 'minor' folds based on the fold wavelength, measured between inflection points. Map-scale minor folds, depicted in subdomains D \& E (Figure 3.6), have wavelengths ranging between $\sim 200-500 \mathrm{~m}$, whereas the major fold that creates the synclinal keel pattern has a wavelength of $\sim 3000 \mathrm{~m}$ (measured in subdomains B \& C, Figure 3.6). Because only the hinge area of the major $\mathrm{F}_{2 b}(\mathrm{SE})$ is preserved, (i.e. adjacent major folds and intervening limbs are not exposed) it is not possible to determine the fold vergence. Where present in some hinges, the $\mathrm{S}_{2 \mathrm{~b}}$ (SE) cleavage is defined by the weak alignment of platy minerals, as well as cm-thick leucosome veins that are axial planar to $\mathrm{F}_{2 \mathrm{~b}}$ (SE) folds (Figure 3.5d). The $\mathrm{S}_{2 \mathrm{~b}}$ (SE) cleavage occurs in psammitic to pelitic cover rocks in the map-scale $\mathrm{F}_{2 \mathrm{~b}}$ (SE) hinges. 
There is a significant difference in volume and thickness of leucosome in $\mathrm{S}_{2 b}(\mathrm{SE})$, the axial planar foliation in $\mathrm{F}_{2 b}$ (SE) folds, relative to that in the main $\mathrm{S}_{2 \mathrm{a}}$ transposition foliation. Cm-thick leucosome veins are aligned parallel to the $\mathrm{S}_{2 \mathrm{~b}}$ (SE) axial planar foliation (Figure 3.5d), whereas $>30 \mathrm{~cm}$-thick melt pods and leucosome veins are concordant with $\mathrm{S}_{2 \mathrm{a}}$ foliation and were folded by $\mathrm{F}_{2 \mathrm{~b}}$ (SE) folds (Figure $3.5 \mathrm{~b}$ ). Based on the decreased volume of $\mathrm{S}_{2 \mathrm{~b}}$ (SE) aligned leucosome veins compared to more voluminous $\mathrm{S}_{2 \mathrm{a}}$ leucosome, it appears that $\mathrm{F}_{2 \mathrm{~b}}$ (SE) folds formed during waning metamorphism late in $\mathrm{D}_{\mathrm{P} 2}$. Alternatively $\mathrm{F}_{2 \mathrm{~b}}$ (SE) folds could be post- $\mathrm{D}_{\mathrm{P} 2}$ structures, formed during renewed anatexis perhaps triggered by the addition of fluids or decompression melting.

In the southeast domain, the $\mathrm{F}_{2 \mathrm{~b}}$ (SE) folds themselves have been refolded, and to characterize the youngest fold structures, structural data were analyzed within a number of subdomains, each with internally consistent $F_{2 b}$ (SE) fold orientations. The geometry of $F_{2 b}$ (SE) folds, within each subdomain, is determined from: stereonet analyses of measured foliation data collected during mapping; and, calculated $\mathrm{S}_{2 \mathrm{a}}$ orientations of map unit contacts determined using structure contours (Figure 3.6). These data are integrated with information from oriented photographs of folds in cliff faces and outcrops (Figures 2.2a, 3.5b-c). Stereograms in Figure 3.6 were created using the techniques outlined in Appendices A and B. Data from five subdomains were chosen for stereonet analyses based on the map pattern: three along the main length of the NW-SE striking couplets of basement-cover rock and the map-scale $\mathrm{F}_{2 \mathrm{~b}}$ (SE) synclinal keel (domains A1-C, Figure 3.6), and two located in the closure of the $\mathrm{F}_{2 \mathrm{~b}}$ (SE) fold (i.e. $\sim \mathrm{N}-\mathrm{S}$ striking couplets of rock), where map-scale $\mathrm{F}_{2 \mathrm{~b}}$ (SE) parasitic folds have tightly folded couplets of rock into overturned synclines and anticlines (domains D-E, Figure 3.6). 
In subdomains $\mathrm{A}(1 \& 2), \mathrm{B}$ and $\mathrm{C}$, the poles to $\mathrm{S}_{2 \mathrm{a}}$ field measurements and mapscale contact orientations both lie on a well-defined pi-girdle on a stereogram (Figure 3.6). The fact that both datasets have very similar orientations indicates that local variations in foliation orientation are generally controlled by map-scale $\mathrm{F}_{2 b}$ (SE) folds. Axial surfaces in subdomains A $(1 \& 2) \& \mathrm{C}$ were calculated by fitting great circles through the fold axes and hinge measurements, whereas in subdomain B the axial surface bisects the obtuse angle between the two sets of limb measurements, and intersects the fold axis. In these three subdomains, the axial surfaces are steeply SW-dipping with strikes that vary from ESE to SSE, and fold axes that are shallow to moderately plunging, with plunge reversals that vary through the horizontal resulting in alternating trends to the ESE or NW (Figure 3.6). The fold axis plunge reversals and changes in axial surface orientation in subdomains $\mathrm{A}(1 \& 2), \mathrm{B}$ and $\mathrm{C}$ are attributed to refolding by younger $\mathrm{F}_{3 \mathrm{a}}$ and $\mathrm{F}_{3 \mathrm{~b}}$ folds (Table 3.1), which are discussed in section 3.6. Folds in these three subdomains range from close to open based on interlimb angles ranging between $47^{\circ}-$ $73^{\circ}$

Subdomain D (Figure 3.6) contains a parasitic fold train identified in an oriented photograph of the cliff face showing folded marker layers in a series of 200-500 m scale, overturned, anticlinal-synclinal-anticlinal parasitic folds (Figure 2.2a). Contact orientations were calculated for the east and west limbs, and the hinge of the overturned synclinal fold, based on the intersection of contacts with topography (Map 1; back pocket, Figure 3.6). The calculated orientations of contacts, together with the poles to $S_{2 a}$ for the entire fold train area, were plotted onto a stereogram for subdomain D (Figure 3.6). The first observation from the stereogram from subdomain $D$ is that the $S_{2 a}$ 
orientations and the calculated contact orientations fall onto two opposing pi-girdles, instead of one. The opposing pi-girdles indicate that perhaps the outcrop scale foliations reflect a different fold generation relative to that of the map-scale structures. Alternately, unmapped faults, that post-dated folding, may have truncated layers and steepened the dips of the basement-cover contacts relative to the surrounding orientations. The nearvertical, NW - SE striking axial surface on the stereogram bisects the acute angle between the two sets of limb measurements and intersects the fold axis for the $\mathrm{S}_{2 \mathrm{a}}$ pigirdle, which is shallowly NW plunging. This axial surface is steeper than that seen in the cliff face, perhaps due to the effect of faulting in the hinge, but both have a similar strike. These folds are classified as close to open folds, with interlimb angles of $\sim 35-81^{\circ}$.

Finally, subdomain E contains a parasitic anticlinal fold (Figure 3.6); the map pattern is inferred from limited mapping and structural form lines interpreted from air photographs. Similar to subdomain D, the data from subdomain E fall on two separate pigirdles on the stereogram, one for the $\mathrm{S}_{2 \mathrm{a}}$ measurements and the other for the calculated contact orientations, indicating that the map pattern is not structurally consistent. Inconsistences in the map pattern could be caused by small-scale structural complexities, such as faulting or another generation of folding imposed on the map-scale $F_{2 b}$ (SE) fold. Based on the $\mathrm{S}_{2 \mathrm{a}}$ pi-girdle, the axial surface is steeply NNW dipping, bisecting the obtuse angle between the two sets of limb measurements and intersects the fold axis for the $\mathrm{S}_{2 \mathrm{a}}$ pi-girdle, which is shallowly $\mathrm{W}$ plunging. This upright, shallowly W-plunging anticlinal fold has an interlimb angle of $\sim 68^{\circ}$, and it is therefore classified as a close fold.

In summary, based on the analyses described above, in the southeast domain, the geometry of $\mathrm{F}_{2 \mathrm{~b}}$ (SE) folds are: parallel, approximately cylindrical (at the subdomain scale) 
and asymmetric, with local parasitic folds within map-scale $\mathrm{F}_{2 \mathrm{~b}}$ (SE) fold hinges. The mapscale $F_{2 b}$ (SE fold that extends the length of the southeast domain has a wavelength of $\sim$ $3000 \mathrm{~m}$. The scale of $\mathrm{F}_{2 \mathrm{~b}}$ (SE) parasitic folds is variable; map-scale minor folds have wavelengths ranging between $\sim 200-500 \mathrm{~m}$, and outcrop scale folds have $\mathrm{cm}$ - to $\mathrm{m}$-scale wavelengths. $F_{2 b}$ (SE) are close to open folds, and are upright to steeply inclined. Because $F_{2 b}$ (SE) folds were refolded (sections 3.6) the axial plane and fold hinge orientations vary. They are gentle to moderately plunging to approximately to the SE or NW, with fold axes plunge reversals that vary through the horizontal due to younger folding. Finally, based on photographs of 300-600 m-high cliff face to outcrop-scale folds, the $F_{2 b}$ (SE) folds have an approximately equant aspect ratio, and are angular to sub-angular in bluntness. $F_{2 b}$ (SE) folds likely formed during the waning stages of regional metamorphism and anatexis, based on the presence of leucosome veinlets aligned parallel to the $\mathrm{S}_{2 b}$ (SE) axial planar cleavage, and are classified as $\mathrm{D}_{\mathrm{P} 2}$ structures. $\mathrm{F}_{2 \mathrm{~b}}$ (SE) parasitic folds of all scales are pervasive throughout the map-scale $\mathrm{F}_{2 b}$ (SE) syncline hinge.

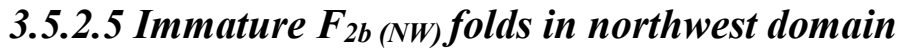

This section describes the geometry and orientation of $\mathrm{F}_{2 \mathrm{~b}}(\mathrm{NW})$ folds in the northwest domain, occurring as both mesoscopic folds at the outcrop and $\sim 400$ m-high cliff scale, that folded the $\mathrm{S}_{2 \mathrm{a}}$ foliation, and map-scale folds that folded the couplets of basement and cover rocks (Figure 3.7a-b Map 1; back pocket).

Map- to outcrop-scale folds in the northwest domain folded $\mathrm{D}_{\mathrm{P} 2}$ structures (i.e. $F_{2 a}, S_{2 a}$ foliation, $L_{2 a}$ lineation, basement-cover couplets, leucosome veins, and boudinaged intrusions; Figure 3.7a-b). There is no evidence for axial planar melt veinlets in hinges of northwest domain $F_{2 b}(\mathrm{NW})$ folds as there are in the axial planes of $\mathrm{F}_{2 b}$ (SE) 
folds in the southeast domain. Subdomains ' $J$ ', ' $\mathrm{K}$ ' and ' $\mathrm{L}$ ' (Figure 3.8) were assigned to characterize the geometry of outcrop- to map-scale folds in the northwest domain. Subdomain ' $J$ ' includes measurements from subdomains ' $K$ ' and ' $L$ ' in the stereogram. The fold in subdomain ' $\mathrm{K}$ ', with a wavelength of $\sim 2000 \mathrm{~m}$, consists of moderate to steeply dipping couplets of rocks that form a SW - NE striking west limb, an E - W striking hinge, and NW - SE striking east limb. Poles to calculated contacts plot on a well-defined pi-girdle defining a gently $\mathrm{W}$-plunging fold axis. A gently inclined, $\mathrm{W}-$ dipping axial surface intersects the calculated fold axis, and the map trace of the axial surface (Figure 3.8). The interlimb angle of this open fold is $\sim 110^{\circ}$.

The geometry of the fold in subdomain ' $\mathrm{L}$ ' is similar to that of subdomain $\mathrm{K}$ (Figure 3.8). An anticline - syncline fold train in subdomain 'L' occurs at the map scale, based on variations in contact orientations. Poles to $\mathrm{S}_{2 \mathrm{a}}$ foliation measurements from subdomains ' $\mathrm{K}$ ' and ' $\mathrm{L}$ ' and the surrounding basement-cover couplets plot on a welldefined pi-girdle (subdomain J, Figure 3.8) that is similar to that of subdomains ' $\mathrm{K}$ ' and ' $\mathrm{L}$ '. This indicates that the map pattern in this area is structurally consistent throughout, and that shorter wavelength folds in the area have a similar geometry to the map-scale folds. Information from stereograms is consistent with field observations as shown in Figure 3.7b, where outcrop and $400 \mathrm{~m}$-high cliff-scale folds from the northwest domain are gently inclined and plunge to the $\mathrm{W}$. The varying tightness of the $\mathrm{F}_{2 \mathrm{~b}(\mathrm{NW})}$ folds is the only geometrical difference between large and small scale folds; smaller scale folds tend to be close to open, whereas map-scale folds are typically open. In the northwest domain, $\mathrm{F}_{2 \mathrm{~b}}(\mathrm{NW})$ folds are similar in morphology and fold the same style of older structures as $\mathrm{F}_{2 b}$ (SE) in southeast domain, however no axial planar leucosome was documented in $\mathrm{F}_{2 \mathrm{~b}}$ (NW) 
folds. Therefore, the relative age of folds in the northwest and southeast domains is uncertain.

In summary, the $F_{2 b}(\mathrm{NW})$ folds of the northwestern domain fold the $S_{2 a}$ foliation and the structure that imbricated basement and cover. The $\mathrm{F}_{2 \mathrm{~b}}(\mathrm{NW})$ folds are gently inclined with $\mathrm{W}$-dipping fold axes that plunge gently to the $\mathrm{W}$, and are typically open folds. Outcrop scale folds have wavelengths of $\sim 1-5 \mathrm{~m}$, whereas folds in cliff faces have wavelengths of $\sim 50-300 \mathrm{~m}$.

\subsubsection{Geometry, description and orientation of post-DP2 structures within all structural domains of the map area (DP3 and DP4)}

This section provides descriptions of post-Dp2 structures, which occur in all domains (Figure F, Map 1; back pocket) and are identified based on overprinting relationships. Structures will be presented on a domain by domain basis.

\subsubsection{Southeast domain $-F_{3 a}$ and $F_{3 b}$ fold generations}

In the southeast domain, structures that occurred after Dp2 events include $\mathrm{F}_{3 \mathrm{a}}$ folds, with $\mathrm{S}_{3 \mathrm{a}}$ axial planar cleavages, and $\mathrm{F}_{3 \mathrm{~b}}$ folds. Both $\mathrm{F}_{3 \mathrm{a}}$ and $\mathrm{F}_{3 \mathrm{~b}}$ folds were responsible for bending the map-scale $\mathrm{F}_{2 \mathrm{~b}}$ (SE) syncline in the southeast domain (Map 1; back pocket).

\subsubsection{1 $F_{3 a}$ folds and $S_{3 a}$ crenulation cleavage}

In the southeast domain, $\mathrm{F}_{3 \mathrm{a}}$ folds are interpreted at the map scale, on the basis of variations in orientation of the map-scale $\mathrm{F}_{2 \mathrm{~b}}$ (SE) fold (e.g. subdomain F, Figure 3.9), and 
parasitic folds of this generation which occur at the outcrop scale. Shallow to moderately plunging $\mathrm{F}_{2 b \text { (SE) }}$ fold hinges may plunge either ESE or NW (domain F, Figure 3.9). These plunge reversals, through the horizontal, are likely due to refolding by upright $\mathrm{F}_{3 \mathrm{a}}$ folds. Similarly, the contact orientations within the closure of the map-scale $F_{2 b}$ (SE) syncline (subdomain F, Figure 3.9) have reversals in dip direction, alternating from place to place between ESE and W dipping. Poles to these contact orientations (white foliation symbols, Figure 3.9) plot on a well-defined pi-girdle, and represent the orientation of E and Wdipping limbs in an $\mathrm{F}_{3 \mathrm{a}}$ syncline-anticline-syncline fold train. The pole to the pi-girdle indicates a near-horizontally plunging, $\mathrm{SSW}-\mathrm{NNE}$ trending $\mathrm{F}_{3 \mathrm{a}}$ fold axis, with plunge reversals that vary through the horizontal (Figure 3.9). The $\mathrm{F}_{3 \mathrm{a}}$ axial surface, which bisects the average $\mathrm{E}$ and $\mathrm{W}$ limb orientations (squares, Figure 3.9) and intersects the fold axis, is steeply inclined with an ESE dip. $\mathrm{F}_{3 \mathrm{a}}$ folds have interlimb angles ranging between $117^{\circ}$ and $127^{\circ}$, and have wavelengths in the order of $\sim 700 \mathrm{~m}$.

Within metasedimentary rocks, $\mathrm{F}_{3 \mathrm{a}}$ folds occur as either kinks in the $\mathrm{S}_{2 \mathrm{a}(\mathrm{SE})}$ foliation or as open to gentle $F_{3 a}$ upright folds (Figure 3.10a-c). The $F_{3 a}$ folds have cm-to m- wavelengths, open to gentle tightness, steeply E- or W-dipping axial surfaces, and shallow north- or south-plunging fold axes (Figures 3.9, 3.10). The $\mathrm{mm}$ to $\mathrm{cm}$-scale folding of the penetrative $\mathrm{S}_{2 \mathrm{a}}$ foliation by $\mathrm{F}_{3 \mathrm{a}}$ folds, and alignment of sheared and rotated $F_{3 a}$ limbs into a cleavage that is parallel to the $F_{3 a}$ axial surface, defines a crenulation cleavage $\left(\mathrm{S}_{3 \mathrm{a}}\right.$; Figure $\left.3.10 \mathrm{a}, \mathrm{b}\right)$. Although the $\mathrm{F}_{3 \mathrm{a}}$ folds folded the $\mathrm{S}_{2 \mathrm{a}}$ foliation, superposition of $F_{3 a}$ folds on $F_{2 b}$ (SE) or $S_{2 b}$ (SE) structures was not observed. Unlike $F_{2 b}$ (SE) folds, leucosome does not occur in the hinges nor the axial surfaces of the $F_{3}$ folds. 
When calculated $\mathrm{F}_{3 \mathrm{a}}$ fold orientation data are compared with field measurements, the $\sim \mathrm{N}-\mathrm{S}$ strike direction of the calculated $\mathrm{F}_{3 \mathrm{a}}$ axial surfaces is similar to that of measured $\mathrm{S}_{3 \mathrm{a}}$ crenulation cleavages (Map 1; back pocket). However, the dips are different by $\sim 20^{\circ}$ to $40^{\circ}$, varying through the vertical, resulting in opposing dip directions. Also, the trend of the shallowly plunging calculated $\mathrm{F}_{3 \mathrm{a}}$ fold axes is $\sim \mathrm{N}$ or $\mathrm{S}$, whereas the trend of the shallowly to moderately plunging outcrop-scale $\mathrm{F}_{3 \mathrm{a}}$ hinges is approximately to the $\mathrm{W}$ (Figure 3.9). The orientation discrepancies between outcrop scale $\mathrm{F}_{3 \mathrm{a}}$ generation structures and map-scale structures could have been caused by refolding of $F_{2 b}(\mathrm{SE})$ and $\mathrm{F}_{3 a}$ structures by the steeply inclined, steeply plunging map-scale $\mathrm{F}_{3 \mathrm{~b}}$ folds (discussed in the next section).

In summary, $F_{3 a}$ folds are documented primarily in the closure area of the $F_{2 b}(\mathrm{SE})$ syncline (subdomain F, Figure 3.9), and were responsible for folding $\mathrm{S}_{2 \mathrm{a}}$ foliation and $\mathrm{F}_{2 b}$ (SE) folds, and for causing dip reversals of the basement-cover contacts. Map-scale $\mathrm{F}_{3 \mathrm{a}}$ folds have wavelengths of $\sim 700 \mathrm{~m}$, are generally upright to steeply inclined, are nearhorizontally plunging to the SSE or NNW with fold axes that vary through the horizontal plane, and are typically open to gentle folds. Outcrop scale $F_{3 a}$ folds with cm-scale wavelengths, and weak axial planar cleavages $\left(\mathrm{S}_{3 \mathrm{a}}\right)$, have similar orientations to mapscale $\mathrm{F}_{3 \mathrm{a}}$ folds, and are interpreted to have formed with $\mathrm{F}_{3 \mathrm{a}}$ during a $\mathrm{D}_{\mathrm{P} 3}$ deformation event.

\subsubsection{2 $F_{3 b}$ folds}

The youngest generation of folds in the southeast domain, $\mathrm{F}_{3 \mathrm{~b}}$, is responsible for the change in orientation of couplets of basement-cover rocks and the axial surface of the 
$F_{2 b}$ (SE) syncline (Map 1; back pocket). Although $F_{3 b}$ folds were not mapped in the field, gently folded $\mathrm{S}_{2 \mathrm{~b}}$ leucosome veins in semipelitic schist, on a scale of several cm's, have similar fold orientations as the $F_{3 b}$ folds and are likely small-scale parasitic $F_{3 b}$ folds (Figure 3.5d). Subdomains A1 \& C (Figure 3.6) lie on the $\mathrm{F}_{3 \mathrm{~b}}$ limbs, whereas subdomain $B$ (Figure 3.6) lies in the $F_{3 b}$ hinge. Poles to the $F_{2 b}(S E)$ axial surfaces plot on a welldefined pi-girdle on an equal area stereonet, and the pole to the pi-girdle defines a steeply-plunging, W-trending fold axis (Subdomain H; Figure 3.11). The axial surface is upright and dips steeply to the NW. The interlimb angle of this $\mathrm{F}_{3 \mathrm{~b}}$ fold is $145^{\circ}$. A fold with a similar fold style, in map view, occurs in the Amittuq lake area (domain I, Figure 3.11), and the poles to the calculated limb and hinge orientations reveal a gentle, upright SE-dipping fold, which plunges moderately to the NE (subdomain I, Figure 3.11).

In summary, $\mathrm{F}_{3 \mathrm{~b}}$ folds are predominantly map-scale folds (i.e. with $3000-3500 \mathrm{~m}$ wavelengths) that occur along the length of the $F_{2 b}$ (SE) syncline, and are identified by strike changes in the couplets of basement cover rocks and the $F_{2 b}$ (SE) axial surface. The $\mathrm{F}_{3 \mathrm{~b}}$ folds are steeply inclined, plunge steeply- to-moderately to the $\mathrm{W}$ or NE, and are gentle folds based the interlimb angle of $145^{\circ}$.

\subsubsection{Northwest domain $-F_{4}$ fold generation?}

In the northwest domain, there appears to be a gentle bend in the NE-SW to N-S trending basement-cover contacts and potentially the $\mathrm{T}_{3 \mathrm{c}}$ domain boundary shear zone (e.g. $\sim 1 \mathrm{~km} \mathrm{~W}$ of Niante Harbour, Map 1; back pocket). This bend may be related to $\sim$ NE-SW crustal shortening, during a young DP4 event (Table 3.1); however, more structural data in this area are needed to test this hypothesis. 


\subsubsection{Northern domain structures}

Structural descriptions for the northern domain are based on data from only two traverses; one in subdomain ' $\mathrm{G}$ ' (Figure 3.9) and a second located $1 \mathrm{~km}$ to the south of subdomain ' $\mathrm{G}$ '. Basement rocks are the dominant lithology in the northern domain; however, there is one north-south striking belt of cover rocks exposed in the eastern part of the domain (Map 1; back pocket). Structures that occur in all rock types in this domain include transposed bedding $\mathrm{S}_{0}, \mathrm{~F}_{2 \mathrm{a}}$ folds, $\mathrm{S}_{2 \mathrm{a}}$ foliation, $\mathrm{L}_{2 \mathrm{a}}$ lineation, $\mathrm{F}_{3 \mathrm{a}}$ folds, and $\mathrm{T}_{\mathrm{P}}$ at the base of ' $\mathrm{B}_{\mathrm{ND}}$ ' basement that structurally overlies the 'B?' $+\mathrm{C}_{\mathrm{ND}}$ ' basement-cover couplet (Table 3.1).

Within the cover package, quartzite, marble and amphibolite layers up to 1-2 m thick, are interlayered within psammitic to semipelitic schist, and the compositional layering is interpreted as transposed bedding $\left(\mathrm{S}_{0}\right)$. The $\mathrm{S}_{0}$ contacts, quartz veins within quartzite layers, and micaceous metamorphic minerals are concordant forming a penetrative transposition foliation $\left(\mathrm{S}_{2 \mathrm{a}}\right.$; Figure $\left.2.8 \mathrm{~b}, 3.13 \mathrm{a}\right)$. Rootless, intrafolial, isoclinal folds, with axial surfaces that are concordant with $\mathrm{S}_{2 \mathrm{a}}$, occur within cover rocks are interpreted as $\mathrm{F}_{2 \mathrm{a}}$ folds (Figure $3.3 \mathrm{c}$ ). $\mathrm{F}_{2 \mathrm{a}}$ fold axes are parallel to stretching and mineral lineations $\left(\mathrm{L}_{2 \mathrm{a}}\right)$ defined by quartz rods in quartzofeldspathic rocks and alignment of sillimanite knots in the semipelitic schists, respectively. A strain gradient is present within the belt of cover rock. The easternmost contact between basement (?) and cover $\left(\mathrm{C}_{\mathrm{ND}}\right)$ rocks (Station W078, Map 2; back pocket), interpreted as a non-conformable contact, contains a penetrative foliation and a weak mineral lineation (Figure 3.12b-c), whereas the basement-cover contact to the west of it (W079, Map 2; back pocket), 
interpreted as $\mathrm{T}_{\mathrm{P}}$ for $\mathrm{B}_{\mathrm{ND}}$, contains protomylonite (i.e. grain size reduction, increased volume of matrix and a well-developed stretching lineation; Figure 3.12d). The protomylonite is interpreted as a ductile shear zone with unknown shear sense. Like the southeast and northwest domains, $\mathrm{T}_{\mathrm{P}}$ at the base of $\mathrm{B}_{\mathrm{ND}}$ and the upper non-conformable basement contact of the ' $\mathrm{B}$ ?' $+\mathrm{C}_{\mathrm{ND}}$ ' basement-cover couplet, is concordant with $\mathrm{S}_{2 \mathrm{a}}$ in both basement and cover rocks, and typically dips shallowly-to-moderately to the NW.

A map-scale fold that folded basement-cover contacts (and potentially $F_{2 a}$ folds, $\mathrm{S}_{2 \mathrm{a}}$ foliation, $\mathrm{L}_{2 \mathrm{a}}$ lineation) in the northern domain was identified and classified using stereonet analysis (subdomain G, Figure 3.9). Poles to calculated contact orientations within the hinge and limbs of the map scale fold plot on a well-defined pi-girdle on a stereogram. The pole to this pi-girdle (i.e. the fold axis) plunges moderately to the NE, and the bisecting axial plane for which the strike was measured from the map (Map 1; back pocket) dips steeply to the NW (subdomain G, Figure 3.9). The calculated interlimb angle of the fold is $115^{\circ}$, is classified as an open fold, and has a wavelength of $\sim 800 \mathrm{~m}$. Because the fold deformed the $\mathrm{D}_{\mathrm{P} 2}$ generation of structures it is termed an $\mathrm{F}_{3 \mathrm{a}}(\mathrm{N})$ generation fold. It may be interpreted as the same generation as the $F_{3 a}$ folds in the southeast domain based on a similar orientation and morphology. Poles to $\mathrm{S}_{2 \mathrm{a}}$ measurements in subdomain G (Figure 3.9) plot as a separate cluster away from the pigirdle, indicating that their orientations may have been modified by smaller scale structures of a later generation. However, more data are required to test this prediction.

In summary, the northern domain contains compositional layering $\left(\mathrm{S}_{0}\right)$, mature intrafolial folds $\left(\mathrm{F}_{2 \mathrm{a}}\right)$, syn-transposition structures such as a penetrative foliation $\left(\mathrm{S}_{2 \mathrm{a}}\right)$, lineation $\left(\mathrm{L}_{2 \mathrm{a}}\right)$, basement-cover imbrication, and post-transposition structures such as 
map-scale $F_{3 a}$ folds. A westward stain increase in subdomain $G$ (Figure 3.9) supports the interpretation that the easternmost basement-cover contact may be a reworked depositional contact, whereas the higher strain basement-cover contact to the west of it is interpreted as a ductile shear zone. The map-scale immature $F_{3 a}$ fold dips steeply to the NW, plunges shallowly to the NE, has an open to gentle tightness, and a wavelength of $\sim 800 \mathrm{~m}$.

\subsubsection{Southern domain structures}

The southern domain is dominated by basement rocks. Limited mapping in this domain has identified a $600 \mathrm{~m}$ wide, $3500 \mathrm{~m}$ long, NE - SW striking panel of cover rocks in the NW corner of the domain, $1 \mathrm{~km}$ E of Chidliak Bay (Map 1; back pocket). The rocks at the contact between the strip of cover and the surrounding basement are flaggy, contain a strong transposition foliation $\left(\mathrm{S}_{2 \mathrm{a}}\right)$, and localized $\mathrm{m}$-thick protomylonite zones with well-defined stretching lineation $\left(\mathrm{L}_{2 \mathrm{a}}\right.$; Figure 3.13a-d). The contact is interpreted as a ductile shear zone, with an unknown shear-sense. The basement and cover rocks around this panel of cover have been folded by an upright to steeply inclined, NW-dipping syncline that is near-horizontally plunging to the SW, has a gentle tightness, and a wavelength of $\sim 700 \mathrm{~m}$ (Figure 3.9). This syncline is interpreted as an $\mathrm{F}_{3 \mathrm{a}}$ fold, is similar in orientation and geometry to $\mathrm{F}_{3 \mathrm{a}}$ folds in the southeast domain, and may be correlative. 


\subsection{Domain boundaries - evidence from map pattern \& structures}

The assignment of the four structural domains, described previously, is based on contrasting structural patterns from one domain to the next (Figure F, Map 1; back pocket). This section presents what is known about the nature of the domain boundaries.

The boundary between the southeast and northwest domains is interpreted as a moderate- to steep NW-dipping, SE-directed reverse fault or shear zone $\left(\mathrm{T}_{3 \mathrm{c}}\right)$ on the basis of field observations and map-pattern interpretations. The generally NW-dipping map units of the northwest domain are at a high angle to the upright $\mathrm{F}_{2 b}$ syncline in the southeast domain. The intervening boundary truncates the NW-SE striking contacts of the southeast domain (Figure 3.14a-b, Figure D, Map 1; back pocket). The nature and orientation of $\mathrm{T}_{3 \mathrm{c}}$ is well constrained in the area 1-5 $\mathrm{km} \mathrm{N}$ and $\mathrm{NE}$ of Amittuq Lake, but its northeasterly and southwesterly extent is inferred (Map 1; back pocket). Where the boundary is constrained, there is a high-strain mylonite zone with kinematic indicators indicating a reverse sense of shear (Figures 2.12a, D and G, Map 1; back pocket). The preferred interpretation, therefore, is that the $\mathrm{T}_{3 \mathrm{c}}$ domain boundary is a ductile reverse fault that juxtaposed the NW-dipping panel of basement and cover rocks of the northwest domain against the southeast domain. This is interpreted to be a Dp3 generation of structure because it truncated the major map-scale $\mathrm{F}_{2 b}$ (SE) fold in the southeast domain (Map 1; back pocket).

In the northern domain, the domain boundary between the northern and southeast domains is proposed in order to reconcile structural and lithologic differences between the domains. For example, the $\sim 1000 \mathrm{~m}$ thickness of the north-south striking cover 
package in the eastern part of the northern domain (' $\mathrm{C}_{\mathrm{ND}}$ ', Map 1; back pocket) is in contrast to the $\sim 250 \mathrm{~m}$ - thick panels of imbricated cover in the southeast domain.

Although the contact between 'B0' and ' $\mathrm{C} 0$ ' in the eastern part of the southeast domain is inferred to connect with the contact between the easternmost basement ('B?') and cover (' $\mathrm{C}_{\mathrm{ND}}$ ') in the northern domain (based on one data point in that area, Map 1; back pocket), it is difficult to connect ' $\mathrm{C}_{\mathrm{ND}}$ ' as a northern extension of ' $\mathrm{C} 0$ ' based on the conflicting unit thicknesses. The structural style of the southeastern domain apparently does not extend to the north as evidenced by the change in geometry of contacts between the southeast and northern domains. One explanation for the differing lithological and structural styles is that a domain boundary fault exists between the two domains or 'decks' $\left(\mathrm{T}_{2 \mathrm{c}(\mathrm{N})}\right.$; Map 1; back pocket). Alternatively, the differing structural styles and unit thicknesses between the southeast and northern domains is related to the presence of frontal and lateral ramps, in a brittle or ductile thrust model for basement-cover imbrication. Pre- $\mathrm{D}_{\mathrm{P} 2}$ structural complexities, or rheological contrast between the two domains, may also be controlling factors for the mismatching lithological and structural styles between the northern and southeast domains (as discussed in Chapter 4).

If an inferred $T_{2 c}(\mathrm{~N})$ boundary fault does exist, then it could have juxtaposed the NW-dipping ' $\mathrm{C}_{\mathrm{ND}}$ ' cover panel from the northern domain with the upright folded ' $\mathrm{C} 0$ ' in the northeast part of the southeast domain, resulting in structurally thickened cover in this area. The easterly and westerly extent of $\mathrm{T}_{2 \mathrm{c}}$ is unknown, and the boundary separating the northwest domain from the northern domain is completely speculative and inferred from form lines or trends in airphotographs. Limited field data pertaining to the nature of $T_{2 c}$ (N) between the southeast and northern domain were collected from station C103 (Map 2, 
back pocket). The 10-15 m-thick zone of migmatitic psammitic rocks at this station are strongly deformed and strained as evidenced by strongly attenuated and flattened quartzofeldspathic layers defining a strong $\mathrm{S}_{2 \mathrm{a}}$, and presence of mylonites with a strong stretching lineation (Figure 3.14c). In contrast, cover rocks 50-100 m south of this station apparently have undergone much lower strain, as evidenced by the occurrence of compositional layering, recognizable as transposed bedding. Therefore, there is a significant strain increase within the vicinity of the proposed $\mathrm{T}_{2 \mathrm{c}(\mathrm{N})}$ boundary. Shallow to moderate $\mathrm{W}$-plunging lineations and kinematic indicators within the deformation zone at station C103 indicate that some component of left-lateral (northern domain-to-the-W) strike and oblique-slip displacement occurred in this shear zone (Figure G; back pocket). The presence of strongly sheared rocks along the proposed domain boundary (i.e. station C103), supports the presence of a ductile high-strain zone between the southeast and northern domains, in support of a tectonic boundary between two different crustal blocks or 'decks'.

The southern basement-dominated domain is in thrust contact with the northwest domain, and is in gradational contact with the $\mathrm{F}_{2 \mathrm{~b}}$ (SE) folded basement cover couplets of the southeast domain. The nature of the transition in structural style between the southern and southeast domains is uncertain, but could be related to rheology contrasts in the two domains, or to the extent and limit of Paleoproterozoic $\mathrm{D}_{\mathrm{P} 2}$ reworking of basement rocks. 


\subsection{Structural history of the Ptarmigan Fiord area}

The purpose of this section is to compare structural observations from the northwest, northern, southeast and southern domains and integrate observations into a structural history for the Ptarmigan Fiord area, as summarized in Table 3.1 and the diagrammatic block diagram (Figure H, Map 1; back pocket). The structural history also serves as a framework in which to discuss the potential timing relationships and significance of basement-cover contacts and domain boundaries (i.e. strain and kinematic analyses) in the following sections.

In the southeast and northwest domains, older basement rock are juxtaposed over younger Paleoproterozoic cover rock, along interpreted brittle thrust faults $\left(\mathrm{T}_{\mathrm{P}}\right)$.

Dominant structures in all domains include a penetrative transposition foliation $\left(\mathrm{S}_{2 \mathrm{a}}\right)$ that is concordant with relict or transposed bedding $\left(\mathrm{S}_{0}\right)$, map and marker unit contacts, and is defined by the alignment of thermal-peak metamorphic minerals and the majority of leucosome, mature fold axial surfaces $\left(\mathrm{F}_{2 \mathrm{a}}\right)$, and lower structural contacts $\left(\mathrm{T}_{\mathrm{P}}\right)$ and upper non-conformable contacts in repeated basement-cover couplets. Shear zones with mylonite, which are concordant with $\mathrm{S}_{2 \mathrm{a}}$, occur throughout the imbricated basement and cover, and are interpreted as higher strained equivalents of $\mathrm{S}_{2 \mathrm{a}}$. Mineral and stretching lineations $\left(\mathrm{L}_{2 \mathrm{a}}\right)$ are aligned within $\mathrm{S}_{2 \mathrm{a}}$ and often parallel to $\mathrm{F}_{2 \mathrm{a}}$ fold axes. These structures are interpreted to be the result of a progressive pre- to synthermal peak transposition event $\left(D_{\mathrm{P} 2}\right)$ where the rocks deformed in a predominantly plastic manner. The relative chronology, geometry and complexity of potential pre-transposition structures $\left(\mathrm{D}_{\mathrm{P} 1}\right)$ is 
uncertain because they would have been overprinted by structures that formed during the major tectonothermal DP2 transposition event.

The mature transposition structures were then folded by close to open, immature DP2 folds, which include $F_{2 b}$ (SE) folds in the southeast domain, and $F_{2 b}$ (NW) folds in the northwest domain. $\mathrm{F}_{2 \mathrm{~b}}$ (SE) folds are classified as late $\mathrm{D}_{\mathrm{P} 2}$ immature folds because they have up to one cm-thick axial planar leucosome veins $\left(\mathrm{S}_{2 \mathrm{~b}}\right)$, interpreted to have formed during waning stages of $\mathrm{D}_{\mathrm{P} 2}$ metamorphism and anatexis. $\mathrm{F}_{2 \mathrm{~b}}(\mathrm{NW})$ folds have similar geometry and characteristics as $\mathrm{F}_{2 \mathrm{~b}}(\mathrm{SE})$, and, without more information are provisionally interpreted to have formed during the DP2 tectonothermal event. There is no information available, at present, as to whether or not immature DP2 folds with close-to-open geometries exist in the north and south domains.

Mature and immature DP2 structures were deformed by DP3 folds characterized by open geometries. $\mathrm{D}_{\mathrm{P} 3}$ fold structures occur in the southeast, northern, and southern domains and include $\mathrm{E}$ and $\mathrm{W}$ steeply-dipping $\mathrm{F}_{3 \mathrm{a}}$ folds with $\mathrm{S}_{3 \mathrm{a}}$ crenulation cleavages, and $F_{3 b}$ folds. In the southeast domain, both $F_{3 a}$ and $F_{3 b}$ that folded the $F_{2 b}$ (SE) syncline (Figure H, Map 1; back pocket). DP3 crustal shortening likely resulted from $\sim$ NW-SE horizontal compression based on the orientation of upright $F_{3 a}$ and $F_{3 b}$ folds. The youngest $\mathrm{D}_{\mathrm{P} 3}$ structure is inferred to be the map-scale southeasterly directed ductile reverse fault $\left(\mathrm{T}_{3 \mathrm{c}}\right)$, which juxtaposed the northwestern domain and the southeast domain. The sense of displacement of the southeasterly directed $T_{3 c}$ fault is consistent with the general $\sim$ NW-SE horizontal compression inferred for the $\mathrm{D}_{\mathrm{P} 3}$ folds. $\mathrm{T}_{3 \mathrm{c}}$ is interpreted to be younger than the $F_{3 b}$ folds because it truncates the $F_{3 b}$ folds in the southeast domain (Map 1; back pocket). 
The youngest structures in the study area, which are constrained by few data and are still poorly understood, are gentle, potentially upright, steeply plunging, E or Wstriking folds $\left(\mathrm{F}_{4(?)}\right)$ that bent $\sim$ north-south striking couplets of basement and cover rock in the northwest and north domains (Map 1; back pocket).

\subsection{Preliminary strain and kinematic analysis of Ptarmigan Fiord rocks}

The purpose of this section is to document and evaluate information about the highest strained rocks in the study area, namely localized shear zones and mylonite. Although the basement and cover rocks were penetratively deformed, during the main transposition event $D_{P 2}$, there are localized shear zones and mylonite $\left(\mathrm{S}_{2 \mathrm{a}}\right)$, up to $10 \mathrm{~m}$ thick that also formed during DP2. These zones: 1) coincide with the basal basement contacts $\left(\mathrm{T}_{\mathrm{P}}\right)$, interpreted as structures responsible for duplication of basement-cover couplets; 2) coincide with the upper basement- cover contacts, interpreted as reworked non-conformable contacts; and, 3) occur within the basement sheets. The mylonite zones are described and the results of preliminary microstructural and kinematic analyses are presented. The results are focused mainly on the southeast and northwest domains, as very few oriented samples were collected from the northern and southern domains for structural analysis. A total of twelve oriented basement samples were used for strain and kinematic analyses; eight from the southeast domain and four from the northwest domain. This strain and kinematics analysis is a preliminary study to try and understand the relationship and significance of the mylonites and whether or not they may be responsible for repeated basement-cover thrust duplication in the Ptarmigan Fiord area, or if they 
perhaps represent younger structures related to reworking of ancestral $T_{P}$ thrust faults during $\mathrm{D}_{\mathrm{P} 2}$. All consequent interpretations and proposed models are based on 1:40 000scale mapping and sampling, and limited detailed mapping across one or two contacts. The effects of annealing (Figure 3.15a-d) also hampered the strain and kinematic analysis, as described in the next section.

\subsubsection{Annealed mylonites and local shear zones within the Ptarmigan Fiord area}

Basement samples with similar monzogranitic mineralogical composition were chosen for a preliminary strain analysis. Because localized shear zones are concordant with the penetrative $S_{2 a}$ foliation, it is necessary to define the 'background' foliation before trying to identify higher strained equivalents of it. For the purpose of this study, the background $\mathrm{S}_{2 \mathrm{a}}$ foliation is a penetrative foliation in basement and cover rocks defined by the alignment of compositional layering $\left(\mathrm{S}_{0}\right)$, Archean foliation $\left(\mathrm{S}_{\mathrm{A}}\right)$, boudinaged amphibolite and quartz layers, thermal-peak amphibolite facies minerals, leucosome pods and veins. A weak $\mathrm{L}_{2 \mathrm{a}}$ stretching lineation may occur in association with background $\mathrm{S}_{2 \mathrm{a}}$ (e.g. 'B0' basement in Figure 16.a-b, where basement monzogranite contains a moderately developed foliation and weak stretching lineation). Strain gradients start with the occurrence of a well-defined stretching lineation, and reduction in grain size and formation of bimodal mineral grains size with porphyroclasts and matrix grains (i.e. relative to the grain size of samples, of the same rock type, exhibiting a background $\mathrm{S}_{2 \mathrm{a}}$ foliation).

For the strain analysis, a qualitative classification scheme, ranging from 'undeformed' (i.e. background foliation) to 'moderate' to 'high' strain, is used based on 
the presence or absence of macroscopic mylonites (i.e. grain size reduction without a loss of cohesion) which exhibit S-C fabrics, and strong stretching lineation in hand samples. S-C mylonite nomenclature refers to two foliations (i.e. a compound fabric), labelled ' $\mathrm{S}$ ' (derived from German word 'schiefer', meaning schist) and ' $\mathrm{C}$ ' (derived from the French word 'cisaillement', meaning shear), both of which have developed during a single deformation event (Berthe et al., 1979, White et al., 1980). The S-foliation is the flattening fabric defined by the long axis of porphyroclasts and other structures (Passchier and Trouw, 2005). The $\mathrm{C}$-foliation is continuous, concordant with the compositional layering and represents the orientation of the shear zone (Passchier and Trouw, 2005).

Due to the characteristic features of mylonites, in the field and hand sample, including bimodal grain size with larger asymmetric porphyroblasts in a fine grained matrix and strong stretching lineations (Figure 2.5a), in thin section 'mylonitic' samples were expected to contain highly attenuated quartz and feldspar crystals, quartz ribbons and microstructures such as subgrains and strain insensitive foliation. However, weak to moderately flattened and attenuated quartz crystals with irregular, lobate grain boundaries and straight extinction are prevalent (Figure 2.5b). Other microstructures including: lobate grain boundaries, secondary quartz growth with mineral inclusions, pinning structures, granoblastic quartz textures, and window structures (Figure 3.15a-b) also occur in basement samples. These microstructures indicate that annealing took place. Some low-strain deformation microstructures, in the form of undulose extinction in flattened quartz crystals and rare plagioclase crystals containing deformation twins, are also present (Figure 3.15c-d). These low-strain microstructures are interpreted to have formed after annealing. Therefore, the strain analysis on basement monzogranite, 
conducted using both macroscopic and microscopic structures has limitations due to annealing. However, on the basis of preserved macroscopic features, as described above, the rocks are interpreted as mylonites, albeit annealed mylonites.

\subsubsection{Strain analysis - southeast domain}

Eight basement samples from the southeast domain were analyzed. They include: 1) rocks located at the basement-cover contacts (sampling both upper and lower basement contacts and cover rock); and 2) basement rocks located within basement sheets (e.g. Station C055 in 'B2', Map 2; back pocket).

\subsection{Strain analyses of basal basement-cover contacts}

The plutonic rocks at the base of the first imbricated 'B1' basement at station W018 (Map 2; back pocket), contain a strong $\mathrm{S}_{2 \mathrm{a}}$ foliation (Figure 3.16c-d), which weathers in 1-10 cm alternating recessive and resistant layers, and is distinctive relative to more resistant outcrops. There appears to be a $\sim 10-20 \%$ reduction in grain size in the basement monzogranite within $2 \mathrm{~m}$ of the contact compared to that from station C039 in 'B0' (Figure 3.16c-d), as well as the development of protomylonitic texture (Figure 3.16c-d). Stretching lineations are penetrative near the contact, and are formed by quartz and feldspar rods in basement rocks and aligned elongate sillimanite-quartz-K-feldspar knots in the structurally lower pelitic cover rocks. The presence of protomylonitic texture, strong stretching lineations and grain-size reduction, allows this sample to be classified as moderately strained, and indicates an overall increase in strain at the base of the imbricated ' $\mathrm{B} 1$ ' basement, relative to the underlying ' $\mathrm{B} 0$ '- ' $\mathrm{C} 0$ ' contact. This discrete 
zone of protomylonite is interpreted as an annealed ductile shear zone, and a higher strained equivalent of the $\mathrm{S}_{2 \mathrm{a}}$ foliation present in the structurally lower 'B0' basement contact rocks.

At the base of imbricated 'B2' and 'B3' basement (e.g. stations C054 and C057 respectively, Map 2; back pocket), there is a further reduction in grain size compared to the rocks at the base of 'B0', increase in the percentage of matrix grains, further flattening, and elongation of quartz and feldspar grains (up to 8 to 1 aspect ratio of grains parallel to stretching direction; Figure $3.16 \mathrm{e}-\mathrm{f} \& \mathrm{~g}$-h respectively). A poorly defined S-C foliation is present in $\mathrm{C} 054$, where the $\mathrm{C}$-foliation is defined by flattened layers of quartz and feldspar (defining the dominant foliation in the rock), and the S-foliation is defined but the long axis of rare feldspar porphyroclasts (Figure 3.16e). However, due to the fine grained nature of $\mathrm{C} 054$ and $\mathrm{C} 057$ (Figure 3.16e and g), the presence of definite S-C foliations cannot be determined. In these finer grained rock types, the $\mathrm{S}_{\mathrm{A}}$ compositional banding (Table 3.1), which is aligned parallel to $\mathrm{S}_{2 \mathrm{a}}$, shows evidence of extension parallel to the lineation in the form of boudinaged mafic-layers (e.g. similar to that seen in Figure 2.3c). However, the extensional features may be a consequence of a component of competency contrast, rather than higher strain. Based on the occurrence of grain size reduction, increased matrix grains, strong flattening and elongation of quartz and feldspar grains, the contacts at the bases of 'B2' and 'B3' are interpreted to be annealed 'high strain' ductile shear zones; and both are higher strained equivalents of $\mathrm{S}_{2 \mathrm{a}}$ at 'B0' and the protomylonitic shear zone at 'B1' lower basement contacts. 


\subsection{Strain analyses within imbricated basement sheets}

Strain analyses from two basement samples collected from within individual imbricated basement sheets will now be presented. Basement monzogranite from station C055 in 'B2' (Map 2; back pocket), is located near the center of the 'B2' basement sheet of the southeast domain. The outcrop contains a strong $\mathrm{S}_{2 \mathrm{a}}$ foliation defined by the alignment of 2-4 mm-thick resistive quartzofeldspathic layers, micas, and boudinaged leucosome veins (Figure 3.17a). These rocks contain a strong stretching lineation defined by quartz rodding and elongate feldspars (up to 5 to 1 aspect ratio of grains parallel to stretching direction). In hand specimen and thin section, samples from station C055 are interpreted as mylonite, evidenced by S-C fabric development, strain shadows around alkali-feldspar porphyroclasts, and a grain size reduction relative to the lower 'B2' basement contact (Figure 3.17b-d). Rocks from station C055 area classified as 'high strain' based on the mylonitic fabric, and demonstrate in the case of 'B2' that localized shear zones, interpreted as annealed shear zones, exist within imbricated basement slices.

Another example of basement located within a basement sheet in the southeast domain, is basement monzogranite from station C036 in 'B0' (Map 2; back pocket), located $\sim 1 \mathrm{~km}$ east of the basement-cover contact, and is interpreted to be from the deepest exposed structural level in the domain. Monzogranite from station C036 contains cm-thick alternating concordant layers of biotite-rich and biotite-poor material, which define a moderately developed $\mathrm{S}_{2 \mathrm{a}}$ foliation (Figure $3.18 \mathrm{a}$ ). In thin section, coarse-grained (i.e. $~ 5-15 \mathrm{~mm}$ diameter) porphyroclasts of alkali feldspar are aligned within roughly planar aggregates (Figure 3.18b). These aggregates are parallel to the $\mathrm{S}_{2 \mathrm{a}}$ foliation plane defined by the preferred orientation of finer-grained matrix biotite, muscovite, and 
flattened quartz and feldspar. Elongate quartz (up to 3 to 1 aspect ratio of grains parallel to stretching direction) defines a weak $\mathrm{L}_{2 \mathrm{a}}$ stretching lineation. Rocks at station $\mathrm{C} 036$ are interpreted to be 'undeformed' based on the weak stretching lineation, similar to those at station C039 (Map 2; back pocket).

Based on the strain analysis from station C055, there is evidence supporting the presence of localized annealed shear zones (at least in 'B2') within the imbricated basement slices ' $\mathrm{B} 1$ ' to 'B3'. There is also evidence that the lowest strained rocks in the southeast domain are found in structurally lowest 'B0' basement, as evidenced by a 'undeformed' sample from station $\mathrm{C} 036$ located $\sim 1 \mathrm{~km}$ east of the 'C0'-'B0' contact, (Map 2; bac pocket), exhibiting a background $\mathrm{S}_{2 \mathrm{a}}$ foliation.

\subsection{Strain analyses of upper basement contacts}

Within 'B0' basement monzogranite, located 1-2 $\mathrm{m}$ from the upper contact with the overlying cover rocks at station C039 (Map 2; back pocket), planar aggregates of coarse-grained, alkali feldspar porphyroclasts with minor strain shadows, platy minerals and moderately flattened quartz and feldspar are aligned in a well-developed $\mathrm{S}_{2 \mathrm{a}}$ foliation (Figure 3.16a-b). The alignment of quartz rods define a weak stretching lineation.

However, no S-C fabric or mylonitic texture are present in this sample, so this sample is interpreted to contain the 'background' $\mathrm{S}_{2 \mathrm{a}}$ foliation.

At the upper non-conformable contact of imbricated 'B2' and 'B3' basement (e.g. stations C099 and C060 respectively, Map 2; back pocket) samples of granodiorite were collected for strain analysis (Figure 3.19a-d) and compared to equivalent rocks 'B2' and 'B3' from the lower basement contact (i.e. C054 and C057, respectively, Figure 3.16). 
Samples from stations C099 and C060 at the upper basement contacts have a strong $\mathrm{S}_{2 \mathrm{~s}}$ foliation defined by the alignment of micas, flattened quartz and feldspar grains, and 5-10 mm-thick quartzofeldspathic layers (Figures 3.19a-d). Rocks at both contacts have a fine grain size, and a strong stretching lineation defined by quartz rods. Unfortunately, the differing protoliths (i.e. monzogranite vs. granodiorite) of the upper and lower basement contacts restricts the use of grainsize reduction as a proxy of strain. However, based on the macro and microscopic structures, both upper contact samples can be classified as 'moderately strained', compared to the 'high strained' lower contacts, and could be interpreted as ductile shear zones. Based on these data, the basement rocks of 'B2' and 'B3' show evidence of localized moderate to high strain shear zones, interpreted as annealed ductile shear zones, at both the lower and upper basement contacts.

'Moderately' strained ductile shear zones are located in the upper nonconformable basement contacts, at least in the case of 'B2' and 'B3' basement slices. Therefore, annealed shear zones are not purely restricted to the lower basement contacts of basement-cover couplets, as suggested from field observations (reflected on Map 1; back pocket, where brittle faults and ductile shear zones are only drawn on the bottom of each basement-cover couplet).

\subsubsection{Strain analysis - northwest domain}

Unfortunately, samples were not collected in the northwest domain from either the upper basement contacts or from within the basement slices, for comparison purposes. Therefore this discussion is restricted to potential strain gradients at the base of basement sheets in the northwestern domain basement-cover couplets, for which there are data. 
Monzogranite at the base of imbricated 'B4' basement (Map 1; back pocket) is strongly foliated, fine-grained, and contains elongate quartz and feldspar grains (up to 3 to 1 aspect ratios), defining a moderate stretching lineation (Figure 3.20a \& b). An S-C foliation is not visible in this fine-grained 'B4' sample, and it is therefore classified as a 'moderately strained' rock based on the fine grain size (relative to structurally lowest ‘B0’ basement) and stretching lineation.

Monzogranite at the base of basement 'B5' (Map 1; back pocket) is also strongly foliated, slightly coarser-grained compared to the 'B4' basement, and contains elongate quartz and feldspar grains (up to 4 to 1 aspect ratios), defining a moderate stretching lineation (Figure $3.20 \mathrm{c} \& \mathrm{~d}$ ). A poorly defined S-C foliation is present in the sample, where the $\mathrm{C}$-foliation is defined by flattened layers of quartz and feldspar (defining the dominant foliation in the rock), and the S-foliation is defined but the long axis of rare feldspar porphyroclasts (Figure 3.20c)., Therefore, this sample of 'B5' monzogranite is also classified as a 'moderately strained' rock based on the stretching lineation and weak S-C foliation.

Monzogranite at the base of basement 'B6' (Map 1; back pocket) contains a welldeveloped C-S foliation, where the C-foliation defined by alignment of micas and flattened quartz, and the S-foliation is defined by the long axis of feldspar porphyroblasts and attenuated and pulled-apart quartzofeldspathic material (Figure 3.20e). There is also the presence of a strong stretching lineation, and a $\sim 10 \%$ reduction of matrix grain size compared to basement 'B5' (Figure 3.20f). Rocks from station L092 (Map 2; back pocket), at the base of 'B6' basement are classified as 'high strain', and are a higher strain equivalent of rocks from the bases of 'B4' and 'B5' basement. 
Finally, the monzogranite at the base of basement 'B7' (Map 1; back pocket) contain a penetrative foliation and well-developed stretching lineation, but are slightly coarser grained compared to rocks at station L092 at the base of 'B6' basement (Figure $3.20 \mathrm{~g} \mathrm{\&} \mathrm{h).} \mathrm{An} \mathrm{S-C} \mathrm{foliation} \mathrm{is} \mathrm{not} \mathrm{visible} \mathrm{in} \mathrm{this} \mathrm{'B7'} \mathrm{basement} \mathrm{sample,} \mathrm{and} \mathrm{it} \mathrm{is}$ therefore classified as a 'moderately strained' rock based on the finer grain size (relative to structurally lowest 'B0' basement) and the well-developed stretching lineation.

These 'moderate to high strained' zones of rock at the bases of northwest domain basement slices, are interpreted as annealed ductile shear zones. Annealed ductile shear zones also occur in the western part of the map area where the cover slices ' $\mathrm{C} 4$ ', ' $\mathrm{C} 5$ ' and 'C6' are truncated or pinched out. These discrete shear zones are interpreted to delineate basement-on-basement contacts within the lower part of basement slices 'B4', 'B5', and 'B6' (Map 1; back pocket), or localized high strain within the basement sheets. NWtrending sheath folds with $\sim 50^{\circ}$ plunges, defined by folded quartz veins, occur in the garnet-biotite amphibolite unit (Figure 3.5) at the top of the cover slice 'C4'(Map 1; back pocket). The presence of 'moderate to high strained' rocks, mylonite, strong stretching lineations and sheath folds indicate zones of high-strain at the bases of basement-cover couplets in the northwest domain. These are interpreted as ductile shear zones, similar in physical features and significance as those observed in the southeast domain.

In thin section, the basement monzogranite samples collected in the northwest domain (Figure 3.20b,d,f,h) appear to have been annealed to a higher degree compared to those in the southeast domain (Figure 3.4b,d,f). This is evidenced from quartz and feldspar minerals in 'B4' that exhibit a partially developed granoblastic texture (Figure 3.20b). This partially developed granoblastic texture was not observed in the 'B3' 
basement contact samples. There is also a matrix grain size increase in 'B4' - 'B6' in rocks from basal basement contacts compared to 'B1' - 'B3' (Figures 3.4 b \& d) basement contacts, which may be related to the degree of annealing. However, the increased matrix grain size could also be a function of original rock grain size and strain history, so less confidence is assigned to it as proxy of annealing.

Therefore, the mylonitic contacts in the northwest domain, which are structurally higher than those in the southeast domain, are also moderate to high strain and may have deformed during $\mathrm{D}_{\mathrm{P} 2}$ transposition deformation. They appear to have undergone greater post-deformation recovery compared to mylonites in the southeast domain, suggesting a difference in strain or thermal history between the two domains.

\subsubsection{Strain analysis - northern domain}

Due to the paucity of mapping in the northern domain, data from only two stations were used for the strain analysis (W078 and W079, Map 1; back pocket). These stations were chosen to test the hypothesis that the easternmost basement-cover contact (W078) represents a lower strained, reworked, non-conformable contact of the 'B?' + ' $\mathrm{C}_{\mathrm{ND}}$ ' couplet, whereas the basement-cover contact west of it (W079) represents the basal shear zone $\left(\mathrm{T}_{\mathrm{P}}\right)$ of 'B $\mathrm{B}_{\mathrm{ND}}$ ' basement.

Outcrop, sample and thin section photographs of basement granodiorite located within the basement-cover contact at each station contain evidence for a strain gradient and an increase in strain from $\mathrm{E}$ to $\mathrm{W}$ (see section 3.6.3 for details). Based on two samples, there is some evidence supporting the hypothesis that the low strain easternmost basement-cover contact (W078) represents a reworked non-conformable contact, whereas 
the higher strain basement-cover contact to the west of it (W079) can be interpreted ductile $T_{\mathrm{P}}$ related to basement-cover imbrication, or reworking of $\mathrm{T}_{\mathrm{P}}$ during $\mathrm{D}_{\mathrm{P} 2}$ resulting in a ductile shear zone. More data from these basement-cover contacts should be collected to properly test this hypothesis.

\subsubsection{Strain analysis - southern domain}

The only basement-cover contact in the southern domain occurs at the base of a $\sim 3.6$ x $0.6 \mathrm{~km}$ strip of cover rocks (i.e. upper basement contact) interpreted as a klippe in the SW of the study area (Map 1; back pocket). The steeply dipping basement and cover rocks at the contact (station L051; Figure 3.13) are parallel to a strong $\mathrm{S}_{2 \mathrm{a}}$ foliation defined by the alignment of compositional layering in both rocks types, shape preferred orientation of flattened minerals and micas, $\mathrm{cm}$-thick leucosome bands, and gneissic banding (Figure 3.13b-d). The strong $\mathrm{S}_{2 \mathrm{a}}$ foliation gives the basement and cover outcrop a distinctive weathering appearance of alternating recessive and resistant layers (Figure 3.13a). A thin section scan of a sample of medium to coarse-grained granodiorite from station L051 (Figure 3.13d) contain elongate quartz and plagioclase grains (with up to 5 to 1 aspect ratios), defining a well-developed stretching lineation.

Based on the outcrop and thin section-scale strain analysis, the basement rocks at the station L051 upper basement contact with cover are classified as 'moderately strained' rocks, and are higher strained compared to those in 'B0' or at station W078 in other domains (Map 1; back pocket), which are interpreted as potential lower strained, reworked depositional contacts. 


\subsubsection{Kinematic indicators in the Ptarmigan Fiord area}

This section documents the range of kinematic indicators used to determine the sense of motion on shear zones in the Ptarmigan Fiord area, including sigma $(\sigma)$ and delta ( $\delta$ ) shaped K-feldspar porphyroclasts within the basement gneiss, S-C fabrics (when present), and asymmetry of pulled-apart gneissic banding. The location of shear-sense indicators and a summary of all kinematic data are shown on Figure G (back pocket).

\subsubsection{Kinematic indicators - southeast domain}

Kinematic data in the southeast domain are presented from shear zones at the base of basement-cover couplets from locations on both the southern and northern limbs of the $\mathrm{F}_{2 b}$ (SE) syncline in the southeast domain. Two stations were evaluated from the southern limb of the fold. Station C055, in 'B2', is located on the steeply NE-dipping southern limb of the upright $\mathrm{F}_{2 \mathrm{~b}}$ (SE) synclinal keel. At this station, basement monzogranite contains a lineation plunging $48^{\circ}$ to the NW and, $\sigma$-type porphyroclasts indicating an oblique-slip with sinistral sense of shear (Figure 3.17b-d, Figure G, Map 1; back pocket). A similar shear sense is recorded in a structurally lower base of imbricated 'B1' basement on the steeply NE-dipping southern limb of the $F_{2 b}$ (SE) synclinal keel, at station W018. Here, finer grained $\sigma$-type porphyroclast indicators, aligned parallel to a $\sim$ north-trending lineation with a plunge of $44^{\circ}$, indicates oblique-slip with a sinistral shear sense (Figure 3.21a-c, Figure G, Map 1; back pocket). Based on these two shear indicators from the southern half of the synclinal keel, the inferred sense of motion is an oblique-sinistral shear sense. 
Two stations were evaluated from the northern limb of the fold. At station C061 in 'B2', on the steeply south-dipping northern limb of the upright $F_{2 b}$ (SE) synclinal keel, the stretching lineation plunges shallowly at $20^{\circ}$ to the $\mathrm{W}$, on a steeply south-dipping foliation. The asymmetry of $\sigma$-type porphyroclasts, with respect to the shear plane, indicates a predominantly strike-slip, sinistral shear sense (Figure 3.21d-f, Figure G, Map 1; back pocket). Farther W, station W024, located on a structurally higher base of imbricated 'B3' basement, also has a W-trending lineation plunging moderately at $34^{\circ}$, on a steeply SW-dipping foliation. The shear sense at this station is also an obliquesinistral displacement, as indicated by a large $\sigma$-type K-feldspar porphyroclast within granodiorite (Figure 3.21g). Based on these two shear indicators from the northern limb of the synclinal keel, the inferred shear sense is sinistral, with an apparent oblique strikeslip sense of shear (Figure G; back pocket).

\subsubsection{Kinematic indicators - northwest domain}

In the northwestern domain, at station C090 in 'B4', a macroscopic shear-sense indicator located within an internal shear zone, and is defined by the extension of a biotite-rich schist layer in a gneissic basement unit, is concordant with a moderately NWplunging lineation on a moderately NW-dipping foliation (Figure 2.3c). This extensional kinematic indicator represents a top-to-the-SE reverse sense of shear. In the structurally higher basement-cover contact at stations L092 in 'B5' (Figure G; back pocket), a moderately NE-plunging lineation on a SW-striking foliation, has $\sigma$-type K-feldspar porphyroclast, and an S-C foliation recording a top-to-the-SW, oblique-dextral shear sense (Figure 3.20e \& f). At station W060 in 'B6', $\sigma$-type indicators defined by a K- 
feldspar porphyroclasts, are concordant with a moderately W-plunging lineation on a moderately SW-dipping foliation (Figure 3.22a). The $\sigma$-type kinematic indicators indicate an oblique-dextral sense of shear (Figure G, Map 1; back pocket).

Based on these observations, the shear sense indicators from the northwestern domain of the map area, at the base of the basement slices in basement-cover couplets, indicate an overall top-to-the-SW to E sense of shear with oblique-dextral displacement (Figure G; back pocket).

\subsubsection{Summary of preliminary strain and kinematic analysis of basement - cover contacts}

All samples from basement shear zones show microstructural evidence for annealing, which added a level of complexity to the strain analysis. There is some evidence suggesting that basement rocks in the northwest domain may have annealed to higher degree compared to those in the southeast domain. The lowest strained rocks in the study area were identified in the structurally lowest 'B0' basement. The 'moderate to high strain' bases of basement slices within 'B1'to'B3' in the southeast domain, and 'B4' to 'B7' in the northwest domain, are interpreted to represent annealed ductile shear zones. These data support the presence of a strain gradient, where strain appears to increase with ascending structural level.

Two samples analyzed from upper basement contacts in 'B2' and 'B3' (stations C099 and C060 respectively, Map 2; back pocket), show evidence of 'moderate strain', and are also interpreted as discrete ductile shear zones. Based on these data, not all upper basement contacts are low strain (interpreted as depositional contacts), as initially 
suggested by field mapping, suggesting that some of them may have been reactivated as ductile shear zones during $\mathrm{D}_{\mathrm{P} 2}$, or post-D 2 folding. There is also evidence of high strain rocks within basement sheet 'B2' based on sample C055 (Map 2; back pocket) in the southeast domain. The significance of this preliminary strain analysis on potential models for basement-cover imbrication, and the tectonic evolution of the study area, will be discussed in Chapter 4.

Two general shear-sense orientation are inferred based on kinematic data in annealed shear zones in the southeast and northwest domains. The first is an inferred oblique-sinistral shear sense, which is dominant in the southeast domain, and the second is a top-to-the-SE and SW reverse to oblique-dextral sense of shear, dominant in the northwest domain (Figure G, Map 1; back pocket). The presence of overall top-to-the-SE, reverse-sense kinematic indicators in the northwest domain is consistent with inferred SE-directed shortening responsible for overthrusting the northwest domain onto the southeast domain along the $T_{3 c}$ ductile fault. An overall oblique-sinistral shear sense is recorded in the annealed mylonite zones in the southeast domain. This shear sense is more challenging to explain; one explanation is that kinematic indictors in the southeast domain record the displacement history related to the reactivation of basement-cover contacts by post-DP2 folds. The significance of the kinematic data in the southeast and northwest domains, with respect to the tectonic evolution of the Ptarmigan Fiord area, will be explored in Chapter 4 .

This kinematic analysis is a preliminary study, with not a great deal of confidence assigned to the data (e.g. some samples only possessed one kinematic indicator, when usually more than one independent kinematic indicator is required in a rock before 
confidence can be given to the interpreted sense of displacement). Some samples also had contradictory kinematic indicators. Therefore, a fulsome kinematics study, with a strategic sampling program, is required to completely assess the kinematic history of the study area.

\subsection{Summary and Conclusions}

Juxtaposition of older Archean basement over younger Paleoproterozoic cover rocks in the Ptarmigan Fiord area is interpreted to be the result of early thrust stacking ( $\mathrm{D}_{\mathrm{P} 1}$ ?) of basement-cover couplets along discrete brittle faults or ductile shear zones $\left(\mathrm{T}_{\mathrm{P}}\right.$; Figure 2.2b, Map 1; back pocket). Thrust imbrication occurred when the rocks were cool and strong enough to break and translate as competent sheets.

All rocks in the study were penetratively deformed, transposed and metamorphosed at amphibolite-facies conditions during a major tectonothermal event termed $\mathrm{D}_{\mathrm{P} 2}$ (Table 3.1). 'Mature' structural elements related to $\mathrm{D}_{\mathrm{P} 2}$ include the transposition foliation ( $\mathrm{S}_{2 \mathrm{a}}$; Figure 3.2) with local 5-10 m thick shear zones of annealed mylonite, stretching lineation ( $\mathrm{L}_{2 \mathrm{a}}$; Figure 3.3a-b), and intrafolial or mature folds $\left(\mathrm{F}_{2 \mathrm{a}}\right.$; Figure 3.3c-d) as summarized in Table 3.1.Based on stereonet analyses of map and outcrop-scale folds, 'mature' $\mathrm{D}_{\mathrm{P} 2}$ structures are folded by three generations of folds. These include 'immature' map- to outcrop-scale $F_{2 b}$ folds, which are close to open, upright to steeply inclined in the southeast domain ( $\mathrm{F}_{2 \mathrm{~b}}(\mathrm{SE})$; Figure 3.5$)$, and gently inclined, open folds with W-dipping fold axes that plunge gently to the $\mathrm{W}$, in the northwest domain (Figure 3.7). Map scale parasitic $\mathrm{F}_{2 \mathrm{~b}}$ (SE) folds are common in the 
southeast domain (subdomains D \& E, Figure 3.6). Immature $F_{2 b}$ folds are interpreted to be late- $\mathrm{D}_{\mathrm{P} 2}$ based on associated axial planar $\mathrm{cm}$-thick leucosome veins $\left(\mathrm{S}_{2 \mathrm{~b}}(\mathrm{SE})\right.$ ), interpreted to be anatexis related to waning metamorphism (Figure.3.5d). The $\mathrm{D}_{\mathrm{P} 1}$ and $D_{\text {P2 }}$ structures were then refolded by upright open to gentle $F_{3 a}$ and $F_{3 b}$ folds (Figures 3.10 and 3.11 respectively) and faulted $\left(\mathrm{T}_{3 \mathrm{c}}\right)$ during a late $\mathrm{D}_{\mathrm{P} 3}$ event.

The major structure in the SE part of the map is an upright $\sim \mathrm{NW}$ - striking, tight $\mathrm{F}_{2 \mathrm{~b}}$ syncline that folds three basement-cover couplets. The fold has a wavelength of $\sim 3$ $\mathrm{km}$, occurs over a strike length of $\sim 11 \mathrm{~km}$, and has been refolded. The NW part of the map area comprises a NW-dipping panel of basement rocks and three basement-cover couplets (Figure H, Map 1; back pocket). This NW-dipping panel was juxtaposed against the $\mathrm{F}_{2 b}$ syncline by a moderately NW-dipping, $\mathrm{T}_{3 \mathrm{c}}$ reverse shear zone (Figures 3.14a-b; Figure D, Map 1; back pocket). 
Figure 3.1. Theoretical models illustrating potential structural relationships observed in the Ptarmigan Fiord area: a) Block diagram illustrating the relationships between different generations of structures, and 'mature' folds that formed prior to or during the main deformation event and 'immature' folds (i.e. $F_{2 b}$ ) that folded structures associated with the main deformation event.; b) diagram showing possible deformation sequence in the formation of a transposition foliation $\left(\mathrm{S}_{\mathrm{T}}\right)$. $\mathrm{S}_{1}$ is the enveloping surface of the folds that deformed bedding. $\mathrm{S}_{\mathrm{T}}$ is the transposition foliation. (Modified after Turner and Weiss 1963). 


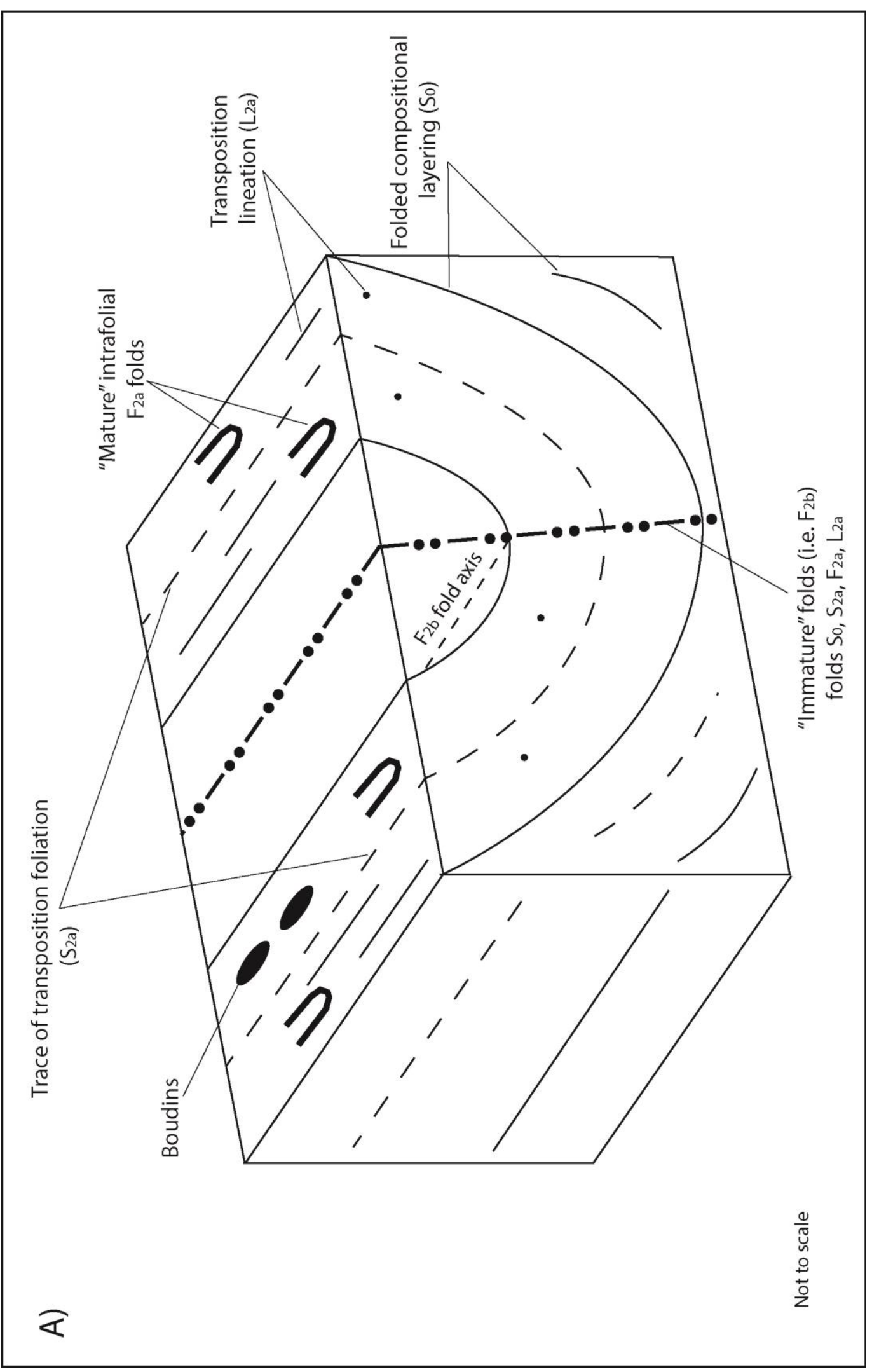



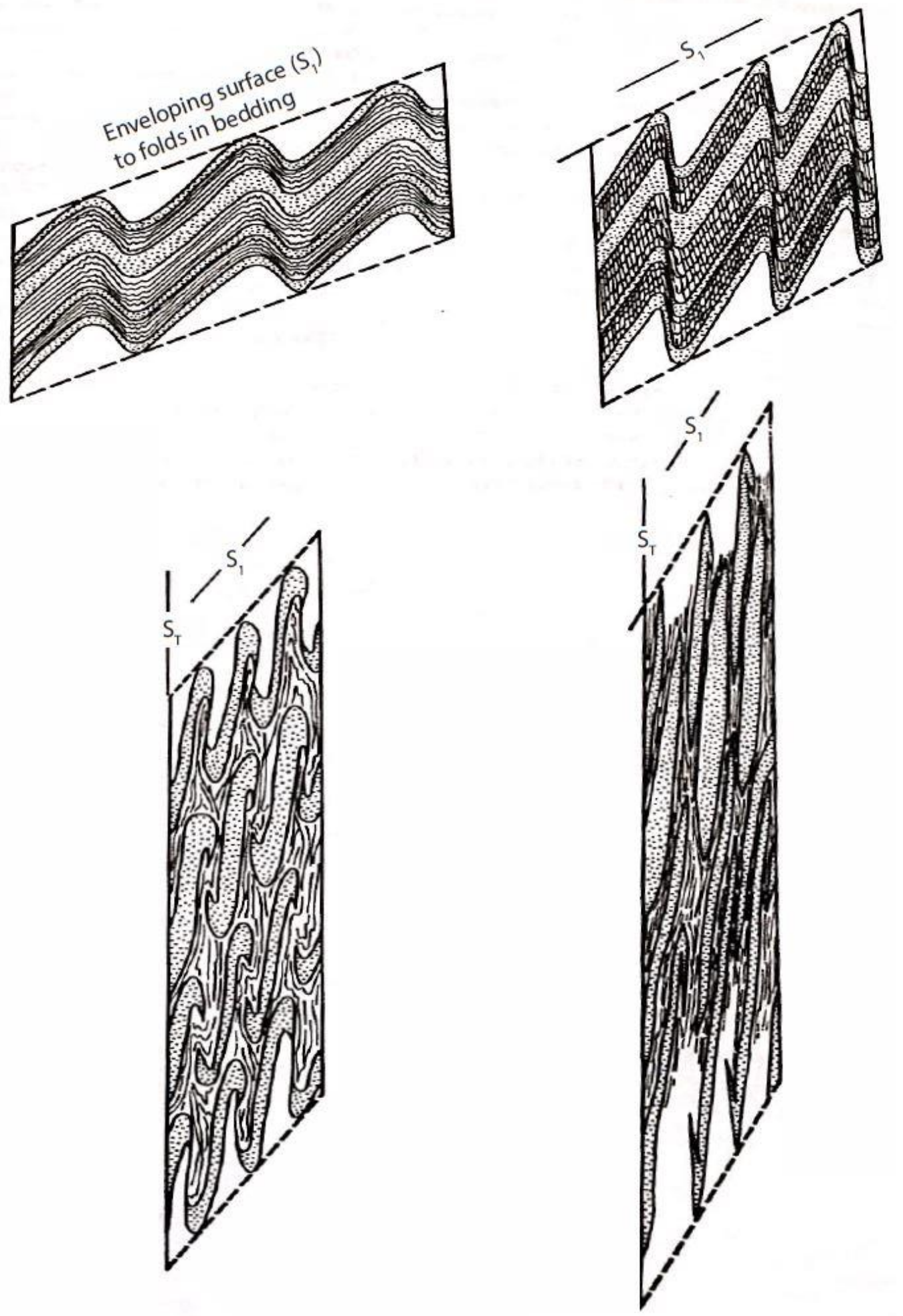
Figure 3.2. Outcrop to hand specimen scale photographs of the transposition foliation $\left(\mathrm{S}_{2 \mathrm{a}}\right)$ within cover rock types, Ptarmigan Fiord, Hall Peninsula of Baffin Island: a) muscovite-biotite semipelitic schist with the $\mathrm{S}_{2 \mathrm{a}}$ foliation defined by traces of aligned muscovite, biotite, flattened quartz grains, and feldspar aggregates and porphyroclasts (note the $8 \mathrm{~cm}$ long scale card for scale). The $\mathrm{S}_{2 \mathrm{a}}$ foliation in this sample is crenulated; b) northward view of quartz boudin that is wrapped by the $\mathrm{S}_{2 \mathrm{a}}$ foliation in psammitic schist (note the $30 \mathrm{~cm}$ long rock hammer for scale); c) northward view of concordant $(1-3 \mathrm{~cm}$ thick) leucosome lenses and veins aligned parallel to the $\mathrm{S}_{2 \mathrm{a}}$ foliation in semipelitic schist (note the $8 \mathrm{~cm}$ long scale card for scale); d) northward view of a grt-bt amphibolite displaying a strong $\mathrm{S}_{2 \mathrm{a}}$ foliation that controls the fracture orientation and weathering of softer more recessive layers within the rock (note the $30 \mathrm{~cm}$ long rock hammer for scale). Abbreviations: Lg, leucogranite or leucosome; Qz, quartz. 

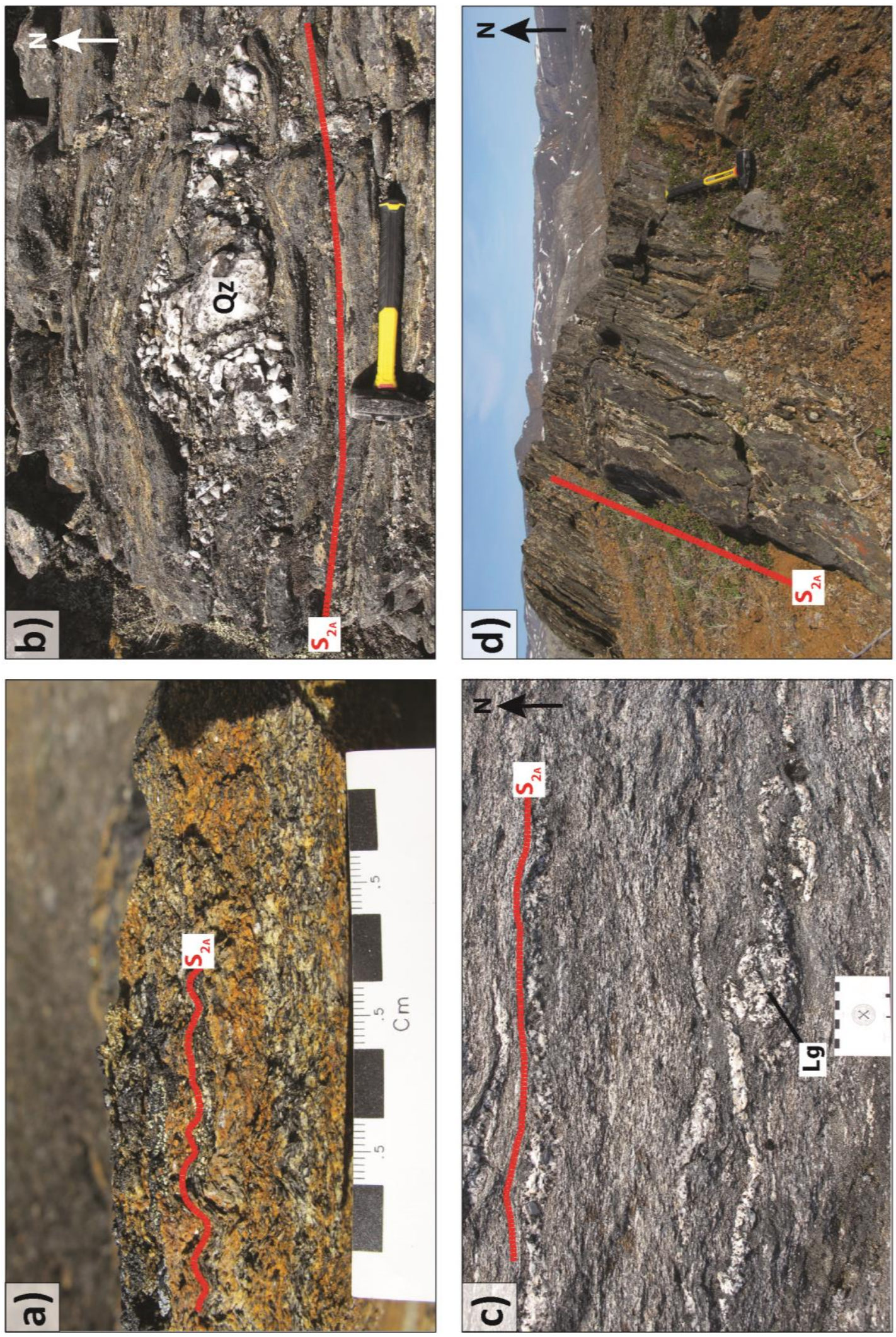
Figure 3.3. Outcrop-scale photographs of the transposition lineation $\left(\mathrm{L}_{2 \mathrm{a}}\right)$ and mature folds $\left(\mathrm{F}_{2 \mathrm{a}}\right)$, Ptarmigan Fiord, Hall Peninsula of Baffin Island: a) northerly view of a L-S psammitic schist from station C088 in 'C3' in the southeast domain (Map 2; back pocket), where $\mathrm{L}_{2 \mathrm{a}}$ is defined by stretched sillimanite and quartz rodding (note the $8 \mathrm{~cm}$ long scale card for scale); b) northerly view of the lineation on the foliation surface in a L-S basement monzogranite, from station W087 at the base of 'B3' (Station Map; back pocket). The trace of the foliation is also visible where it intersects with the outcrop surface (note $30 \mathrm{~cm}$ long rock hammer for scale); c) westward view of foliated semipelitic schist containing intrafolial rootless isoclinal folds $\left(\mathrm{F}_{2 \mathrm{a}}\right)$, defined by folded compositional layering ( $\mathrm{S}_{0}$, black lines), with an axial surface (AS, dashed red line) parallel to the penetrative $\mathrm{S}_{2 \mathrm{a}}$ transposition foliation (dashed red lines; note the $8 \mathrm{~cm}$ long scale card for scale); d) northward view of basement orthogneiss at the base of 'B1' containing an $\mathrm{F}_{2 \mathrm{a}}$ intrafolial isoclinal-to-tight fold defined by a folded tonalite layer $\left(\mathrm{S}_{\mathrm{A}}\right)$. $\mathrm{F}_{2 \mathrm{a}}$ axial surface is parallel to $\mathrm{S}_{2 \mathrm{a}}$, defined by transposed gneissic banding. 

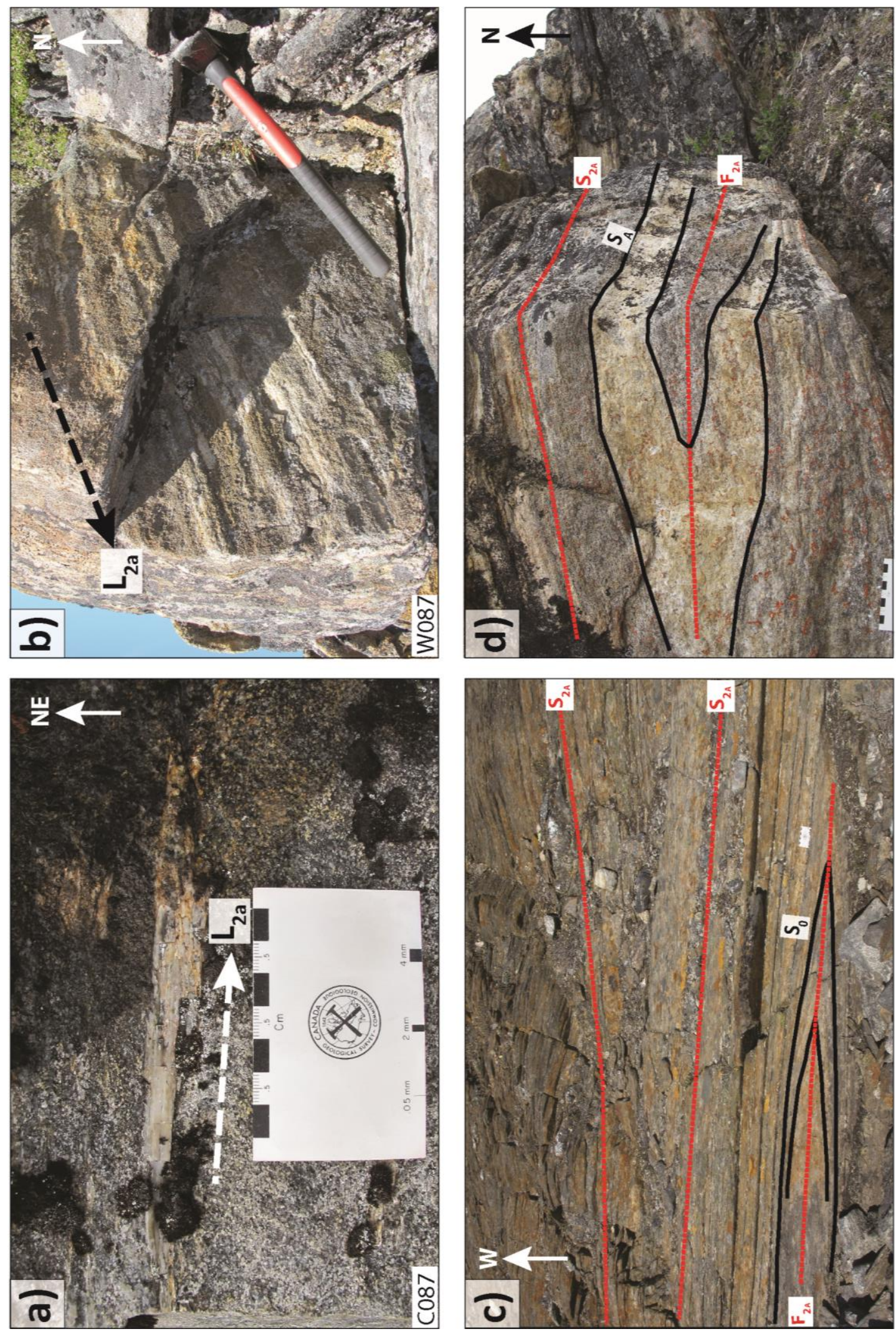
Figure 3.4. Simplified geological map of the Ptarmigan Fiord area showing the locations of the subdomains (i.e. A $-\mathrm{H}$ ) used for the stereonet analysis of map-scale folds. Resulting stereograms of lineation data for each subdomain are overlain on the map, along with measured $\mathrm{L}_{2 \mathrm{a}}$ orientations (black lineation symbols) used for the analyses. The axial traces of map-scale folds in all domains are also included. The orientation of $\mathrm{L}_{2 \mathrm{a}}$ varies throughout the study area, but it typically has a shallow to moderate plunge, trending between northwest and southwest. See legend for explanation of map and stereonet symbols, and see text for explanation of results. 


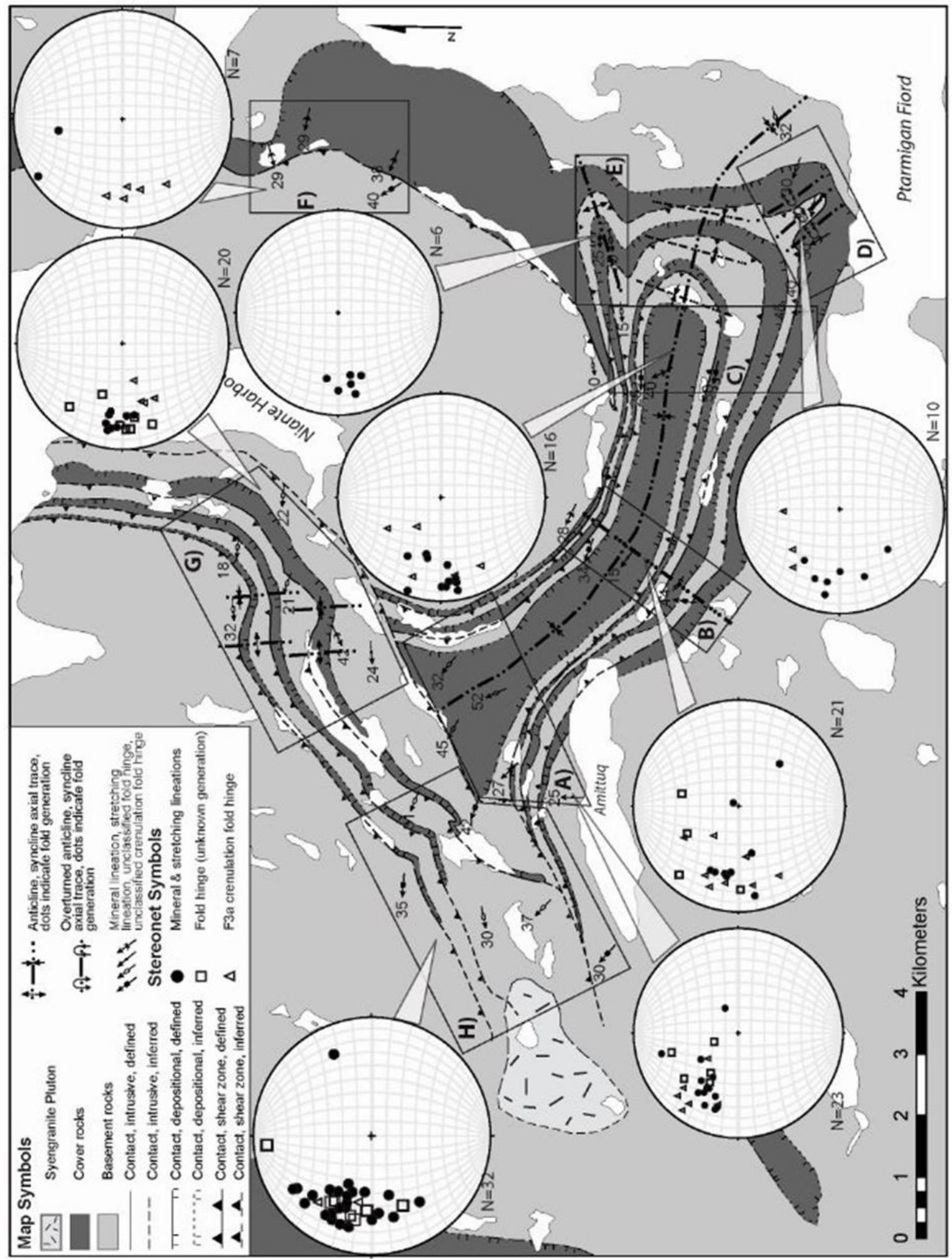


Figure 3.5. Outcrop-scale photographs of a mature sheath fold $\left(\mathrm{F}_{2 \mathrm{a}}\right)$ and examples of $\mathrm{F}_{2 \mathrm{~b}}$ (SE) immature folds, Ptarmigan Fiord, Hall Peninsula of Baffin Island: a) westward view of fine-grained garnet-biotite amphibolite with sheath-folded quartz vein (note the $8 \mathrm{~cm}$ long scale card for scale); b) centimetre-thick alternating layers of light grey-weathering psammitic and rusty brown-weathering garnet-sillimanite-K-feldspar-muscovite schist. Compositional layering, interpreted as primary bedding $\left(\mathrm{S}_{0}\right)$, and $\mathrm{S}_{2 \mathrm{a}}$ transposition foliation with concordant leucogranite or boudinaged veins were folded by $\mathrm{F}_{2 b}$ (SE) folds. Alignment of biotite and sillimanite form a weak $S_{2 b}$ (SE) foliation in the $F_{2 b}(S E)$ axial surface (note the $8 \mathrm{~cm}$ long scale card for scale); $\mathbf{c}$ ) westward view of $\mathrm{S}_{0}, \mathrm{~S}_{2 \mathrm{a}}$ and $\mathrm{cm}$-thick

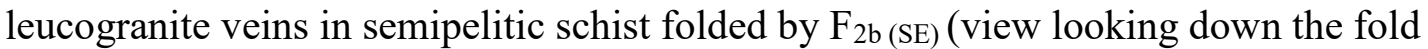
hinge, note the $30 \mathrm{~cm}$ long hammer for scale); d) interlayered psammitic and garnetsillimanite-K-feldspar-muscovite schist on limb of $\mathrm{F}_{2 \mathrm{~b}}$ (SE) fold. Compositional layering, $\left(\mathrm{S}_{0}\right)$ and $\mathrm{S}_{2 \mathrm{a}}$ foliation are at a high angle to $\mathrm{S} 2_{\mathrm{b}}(\mathrm{SE})$ foliation, which is defined by sillimanite and $\mathrm{K}$-feldspar knots, muscovite and biotite minerals and $\mathrm{cm}$-thick quartzofeldspathic veins (note the $8 \mathrm{~cm}$ long scale card for scale). Abbreviations: Amph, amphibolite; Lg, leucogranite or leucosome; Pel, pelitic schist; Psa, psammitic schist Qz, quartz. 

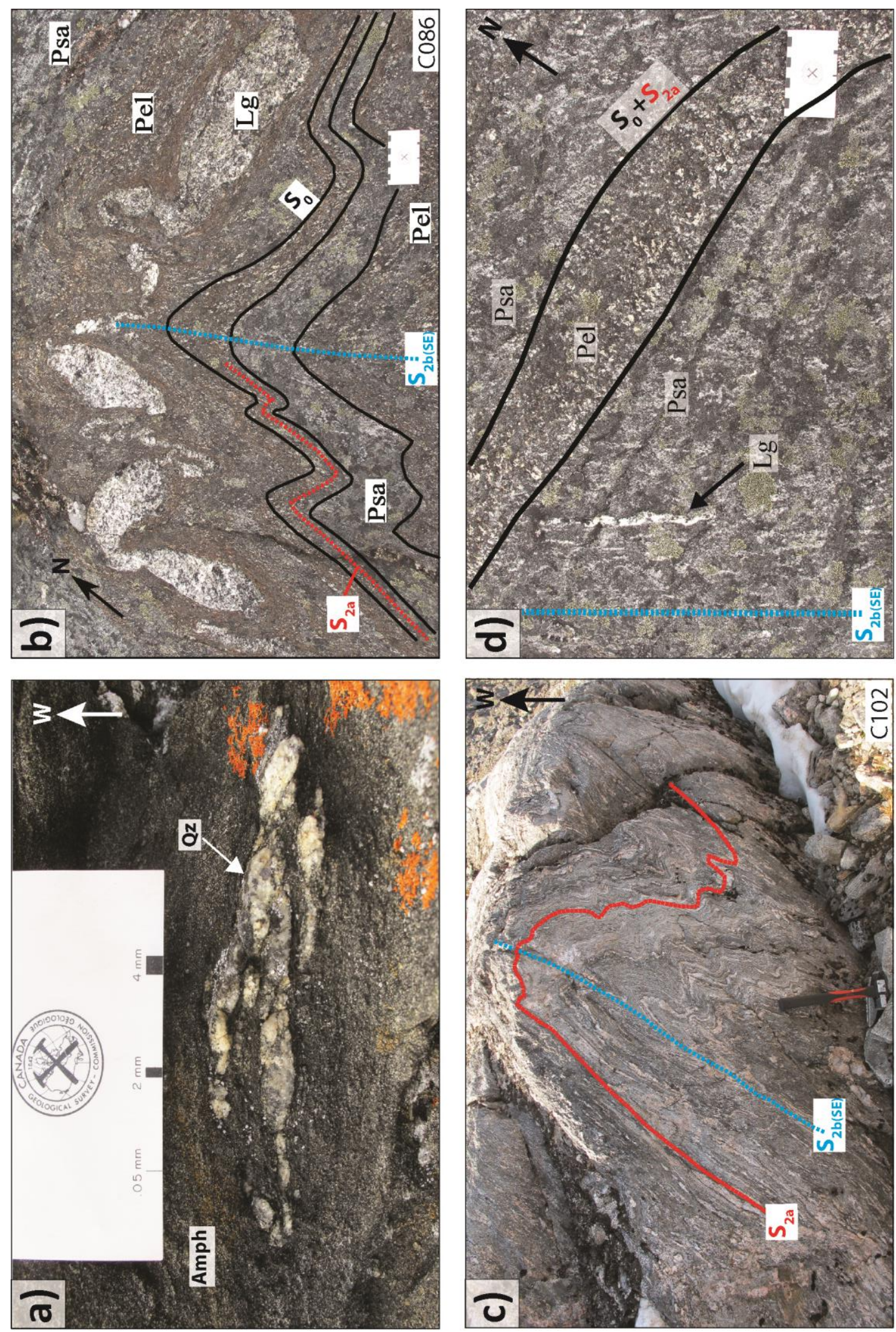
Figure 3.6. Simplified geological map of the Ptarmigan Fiord area delineating locations of the subdomains (i.e. A1, A2, B - D) used for the stereonet analysis of map-scale $F_{2 b}$ (SE) folds. Resulting stereograms for each subdomain are overlain on the map, along with several calculated contacts representing subdomain-scale $\mathrm{S}_{2 \mathrm{a}}$ orientations (i.e. white foliation symbols) and measured $\mathrm{S}_{2 \mathrm{a}}$ orientations (i.e. black foliation symbols). Within each subdomain, the axial traces of map-scale anticlinal and synclinal folds responsible for the upright, close - open folding of basement-cover couplets in the southeast domain, have the same orientation as the calculated axial surfaces on the $F_{2 b}$ (SE) stereograms. Therefore, the synclinal keel map pattern is largely controlled by the $F_{2 b}(\mathrm{SE})$ generation of folds. 


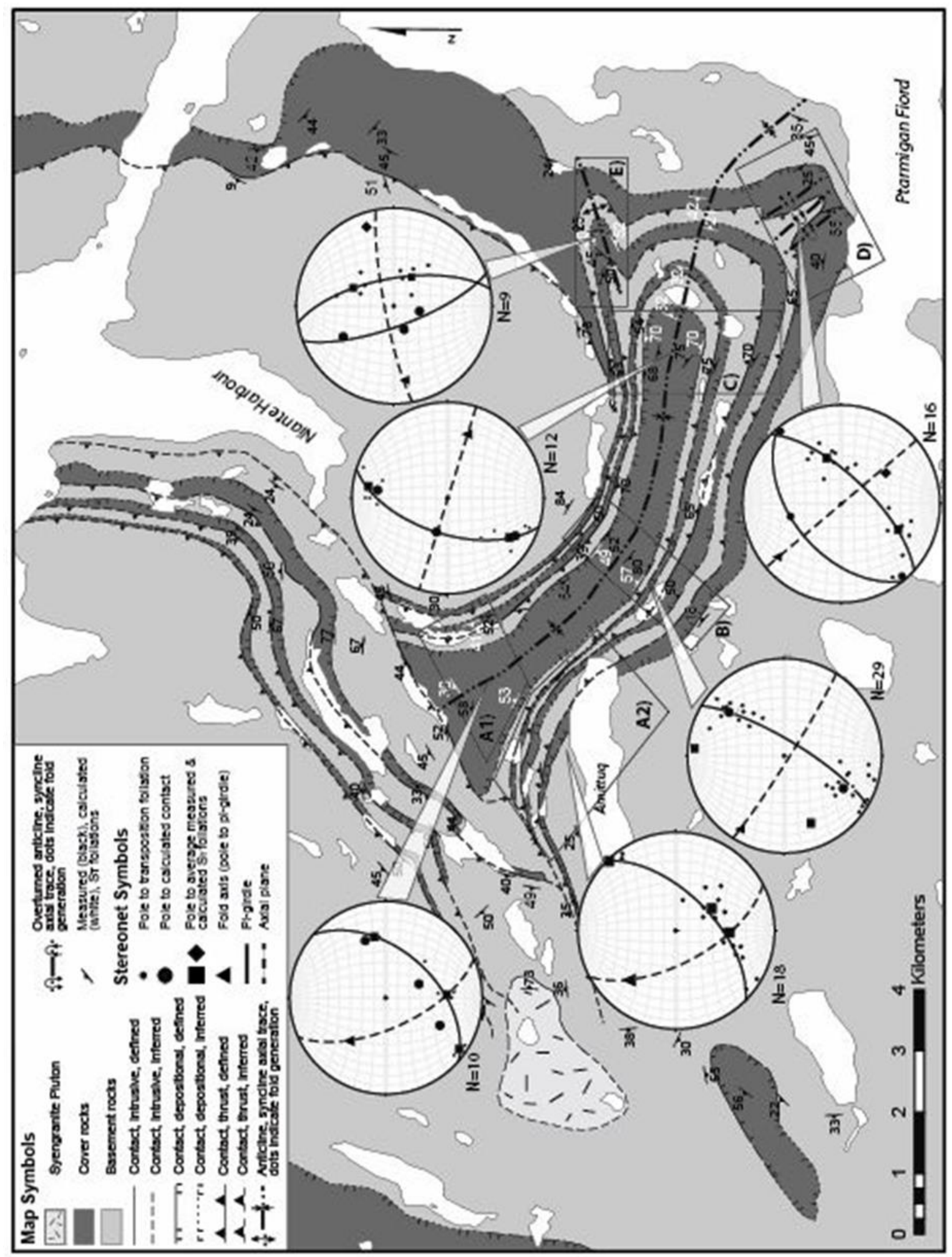


Figure 3.7. Outcrop and cliff side views of $F_{2 b}(\mathrm{NW})$ fold structures in the northwest domain of the Ptarmigan Fiord area, Hall Peninsula, Baffin Island, Nunavut. Photographs are duplicated to allow the reader to view the annotated and unannotated versions of the photographs. a) Westward view of basement orthogneiss belonging to panel 'B5' (Map 1, back pocket), containing a gently inclined, W-dipping close fold ( $\mathrm{F}_{2 \mathrm{~b}}(\mathrm{NW})$, defined by folded gneissic banding ( $1.8 \mathrm{~m}$ tall person for scale). The orientation of the axial surface of this $\mathrm{F}_{2 \mathrm{~b}(\mathrm{NW})}$ fold is similar to the calculated axial surfaces of the gently inclined mapscale $\mathrm{F}_{2 \mathrm{~b}(\mathrm{NW})}$ folds defined by stereonet analysis (Figure 3.9), and is therefore interpreted to be of the same fold generation; b) northwestward view of a cliff-scale $F_{2 b}(\mathrm{Nw})$ fold, with a gently W-dipping axial surface and fold hinge, which is interpreted to be of the same fold geometry as the outcrop-scale example in a). Abbreviations: AS, axial surface. 

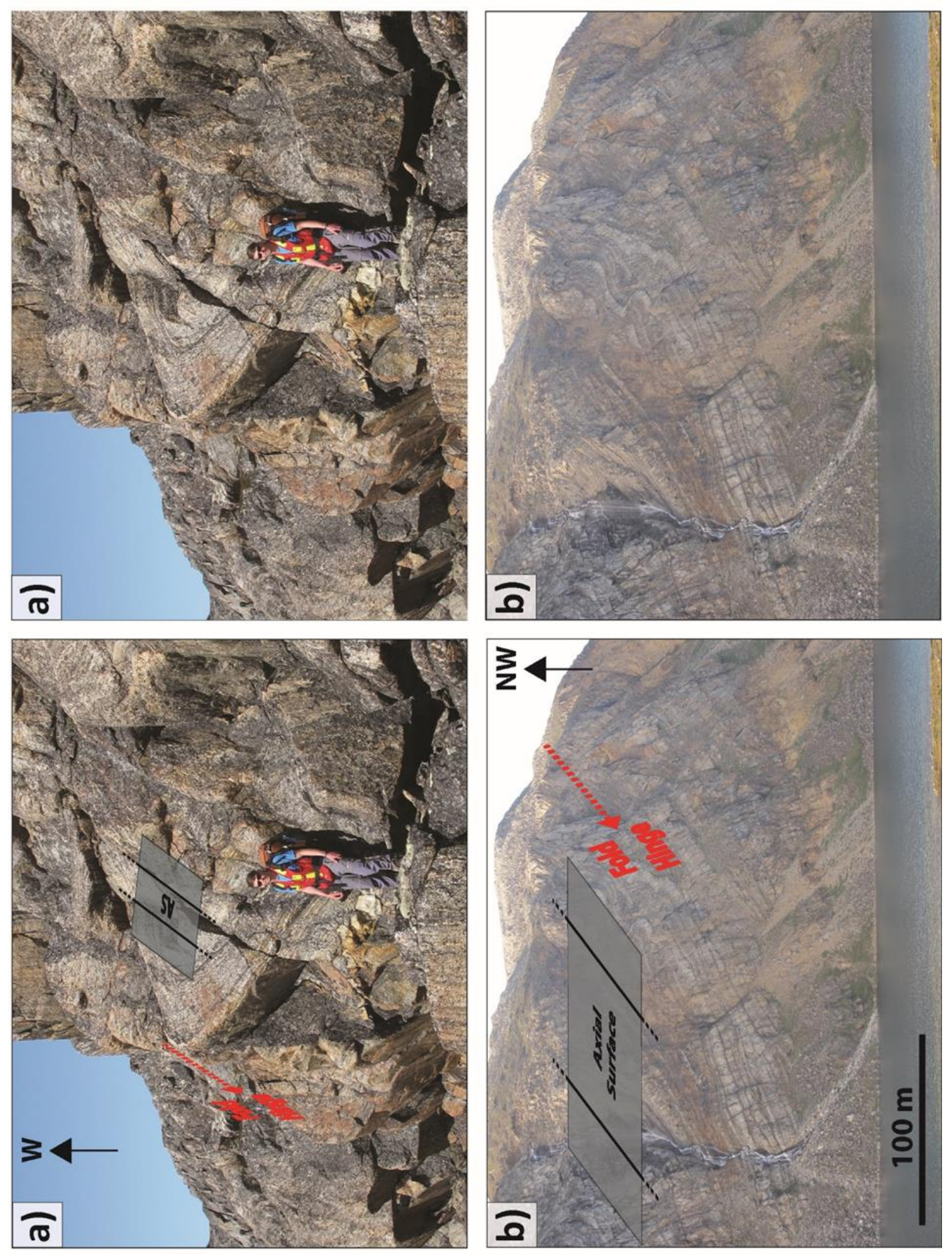
Figure 3.8. Simplified geological map of the Ptarmigan Fiord area delineating locations of the subdomains $\mathrm{J}, \mathrm{K}, \& \mathrm{~L}$ used for the stereonet analysis of map-scale $\mathrm{F}_{2 \mathrm{~b}}(\mathrm{NW})$ folds. Resulting stereograms for each subdomain are overlain on the map, along with several calculated contacts representing subdomain-scale $\mathrm{S}_{2 \mathrm{a}}$ orientations (i.e. white foliation symbols) and measured $\mathrm{S}_{2 \mathrm{a}}$ orientations (i.e. black foliation symbols). The interpreted axial traces of map-scale, gently inclined, open folds responsible for folding the basement-cover couplets in the northwest domain, have the same orientation as the calculated axial surfaces on the $\mathrm{F}_{2 \mathrm{~b}}(\mathrm{NW})$ stereograms. Therefore, the moderately NWdipping panel of basement and cover rocks in the northwest domain are interpreted to have been folded by the $\mathrm{F}_{2 \mathrm{~b}}(\mathrm{NW})$ generation of folds. 


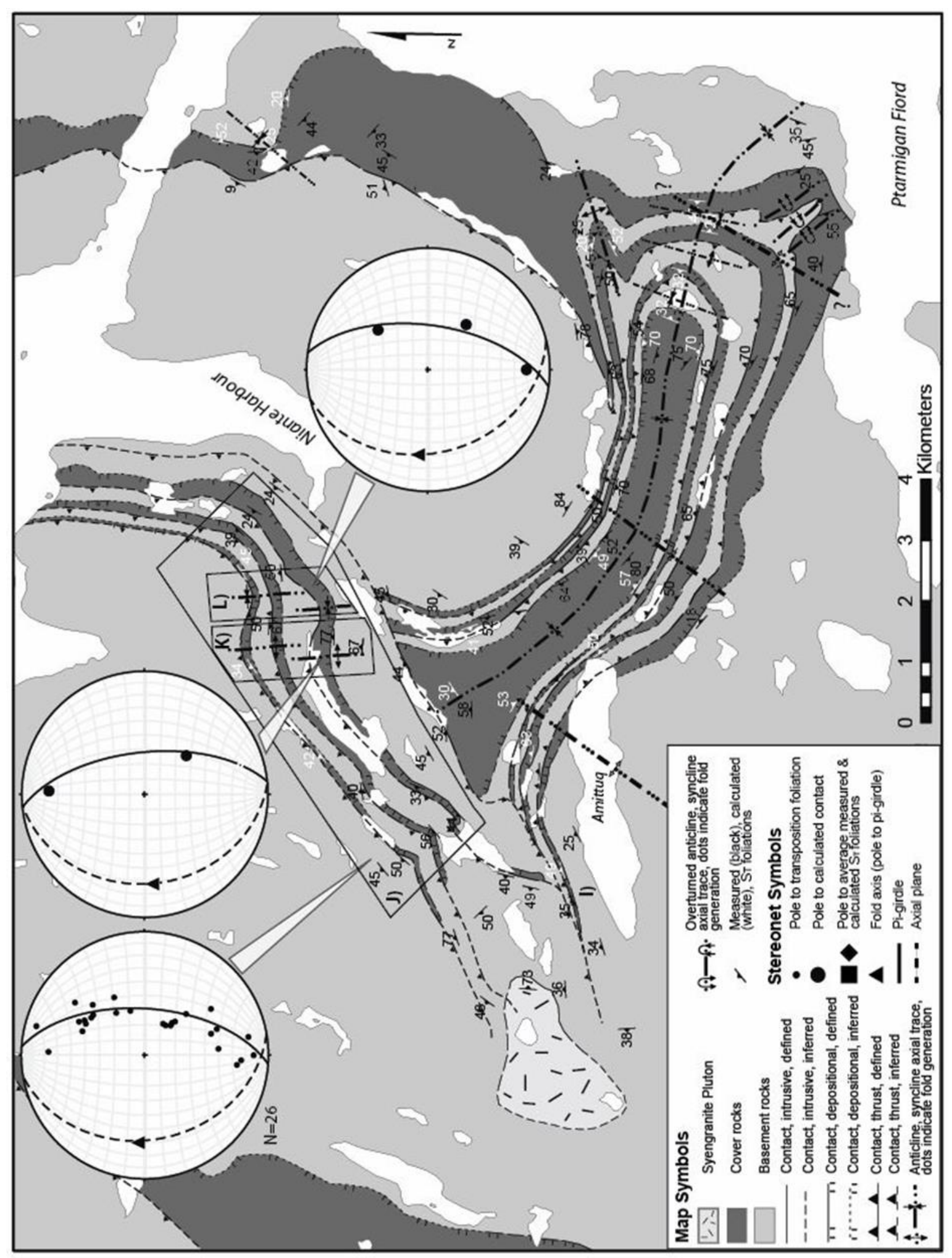


Figure 3.9. Simplified geological map of the Ptarmigan Fiord area delineating the subdomains E, F and G (hollow rectangles) used for the stereonet analysis of map-scale $\mathrm{F}_{3 \mathrm{a}}$ folds. Resulting stereograms for each subdomain are overlain on the map, along with several calculated contacts representing subdomain-scale $\mathrm{S}_{2 \mathrm{a}}$ orientations (i.e. white foliation symbols) and measured $\mathrm{S}_{2 \mathrm{a}}$ orientations (i.e. black foliation symbols). The interpreted axial traces of map-scale folds responsible for the upright, open - gentle refolding of basement-cover couplets in the southeast, northern and southern domains, have the same orientation as the calculated axial surfaces on the $F_{3 a}$ stereograms. Therefore, these map scale folds are interpreted as F3a generation folds. 


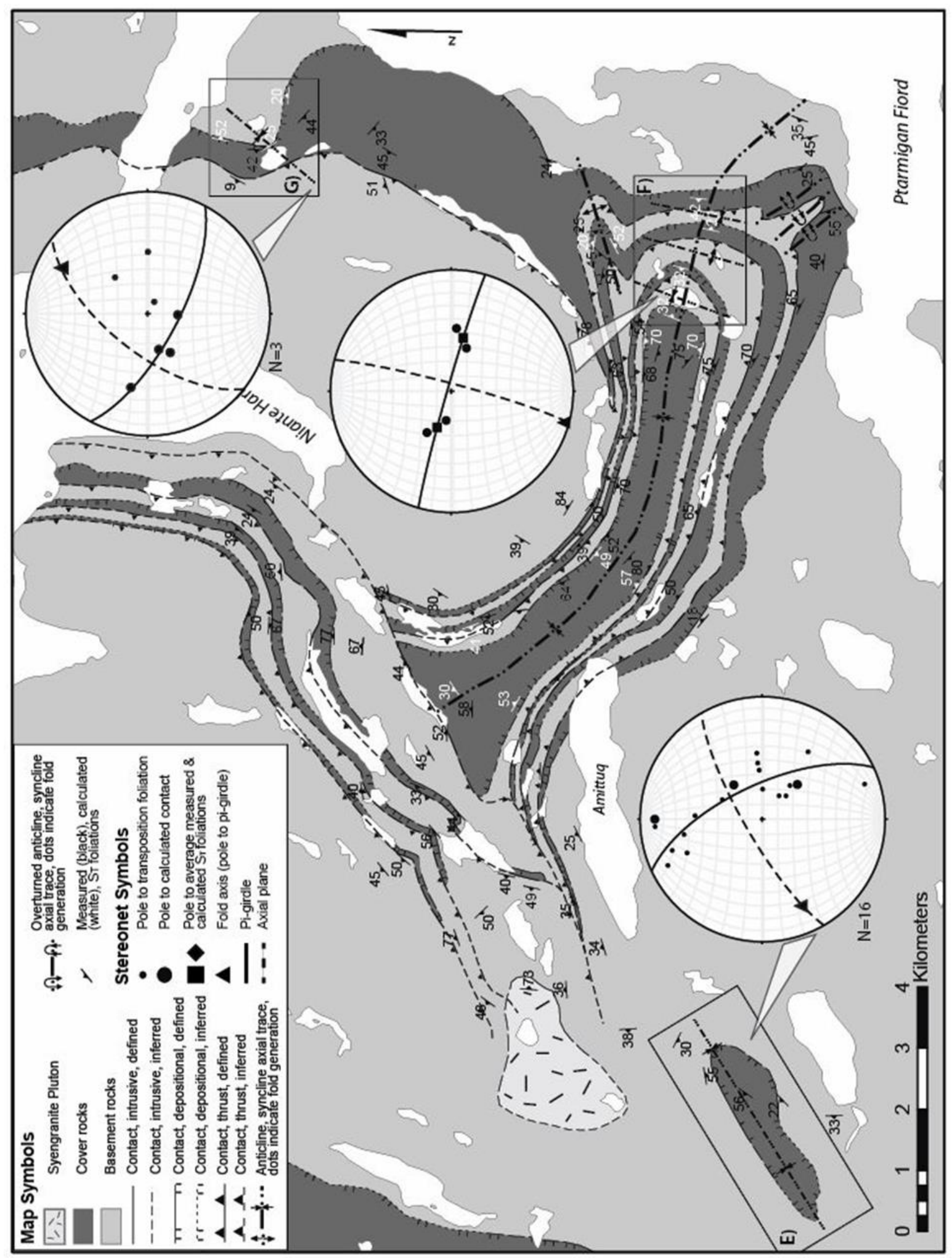


Figure 3.10. Outcrop photographs of $F_{3 a}$ fold structures in the Ptarmigan Fiord area, Hall Peninsula, Baffin Island, Nunavut. a) Southward view of rusty brown-weathering semipelitic schist with an E-W striking penetrative $\mathrm{S}_{2 \mathrm{a}}$ foliation that is crenulated by upright, $\sim \mathrm{N}-\mathrm{S}$ striking $\mathrm{F}_{3 \mathrm{a}}$ folds (note the $8 \mathrm{~cm}$ long scale card for scale); b) westward view of micaceous pelitic schist with an E-W striking penetrative $\mathrm{S}_{2 \mathrm{a}}$ foliation that has been crenulated by cm-wavelength, $\sim \mathrm{N}-\mathrm{S}$ striking, open $\mathrm{F}_{3 \mathrm{a}}$ folds. The short limbs of the crenulation folds have been sheared and rotated into a cleavage that is parallel to the $\mathrm{F}_{3 \mathrm{a}}$ axial surface $\left(\mathrm{S}_{3 \mathrm{a}}\right.$, aligned parallel to pencil; note the $8 \mathrm{~cm}$ long scale card for scale); c) northward view of upright gentle $\mathrm{F}_{3 \mathrm{a}}$ folds in amphibolite (note the $8 \mathrm{~cm}$ long scale card for scale). 

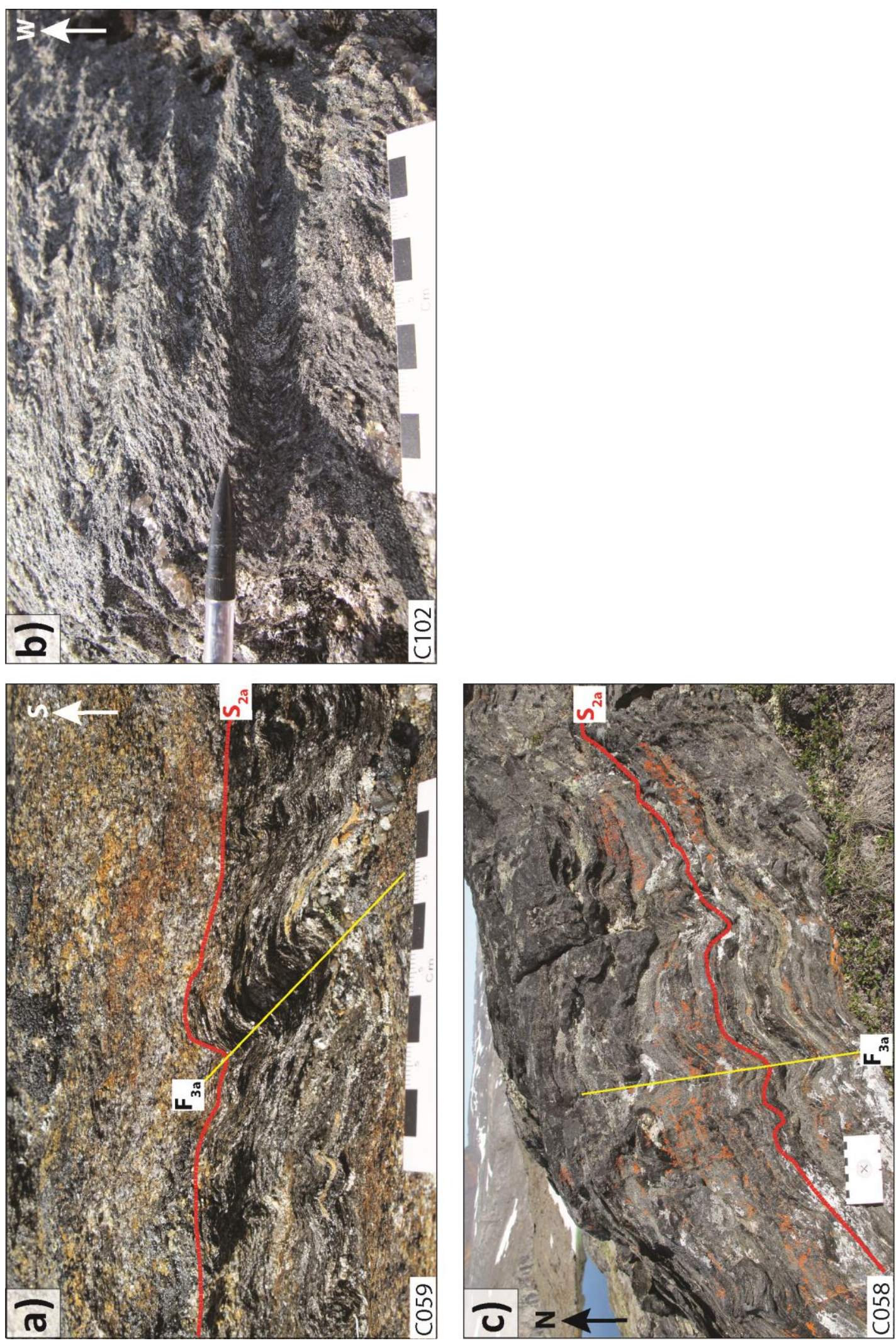
Figure 3.11. Simplified geological map of the Ptarmigan Fiord area delineating the subdomains $\mathrm{H}$ and I (hollow polygons) used for the stereonet analysis of map-scale $\mathrm{F}_{3 \mathrm{~b}}$ folds in the southeastern domain. Resulting stereograms for each subdomain are overlain on the map, along with several calculated contacts representing subdomain-scale $\mathrm{S}_{2 \mathrm{a}}$ orientations (i.e. white foliation symbols) and measured $\mathrm{S}_{2 \mathrm{a}}$ orientations (i.e. black foliation symbols). The interpreted axial traces of map-scale anticlinal and synclinal folds responsible for gentle folding of the entire synclinal keel map pattern in the southeast domain, have the same orientation as the calculated axial surfaces on the $F_{3 b}$ stereograms (subdomain H, I). Therefore, the synclinal keel map pattern is interpreted to have been bent by the $\mathrm{F}_{3 \mathrm{~b}}$ generation of folds. 


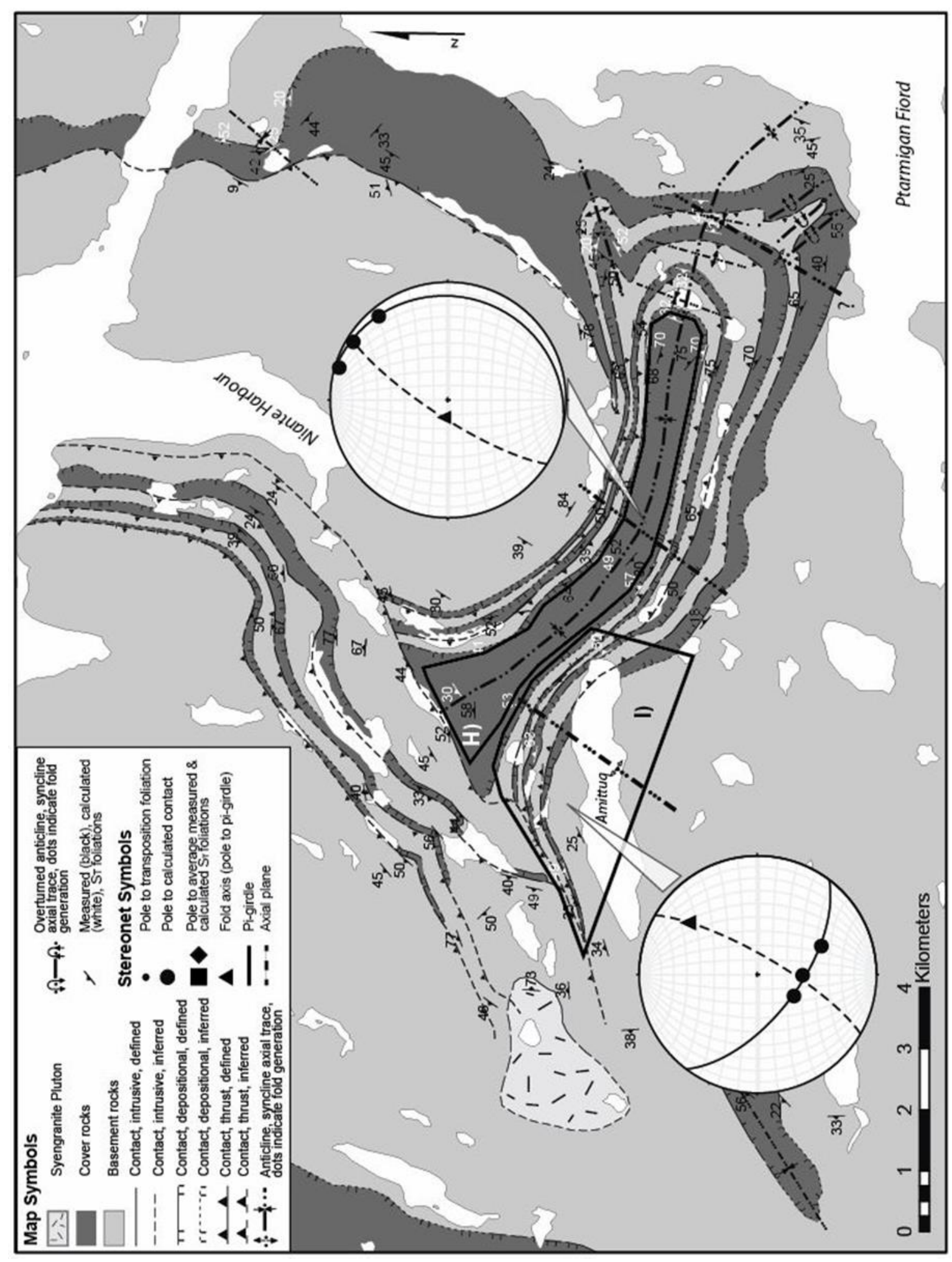


Figure 3.12. Photographs and photomicrographs of northern domain structures, Ptarmigan Fiord area, Hall Peninsula, Baffin Island, Nunavut. View in photomicrographs is of the motion plane, oriented parallel to $\mathrm{L}_{2 \mathrm{a}}$ and perpendicular to $\mathrm{S}_{2 \mathrm{a}}$. a) westward view of the trace of the transposition foliation $\left(\mathrm{S}_{2 \mathrm{a}}\right)$ within quartzofeldspathic rocks; $\left.\mathbf{b}\right)$ basement rock slab from the easternmost contact between basement and cover rocks (station W078, Map 2; back pocket) contains a penetrative foliation and a weak mineral lineation, interpreted as a lower strain reworked depositional contact; c) thin section scan in cross-polarized light of 'low strain' basement rock from easternmost basement-cover contact (station W078); d) basement monzogranite at the basement-cover contact (Station W079; Map 2; back pocket) to the west of W078 contains a strong foliation defined by flattened porphyroclasts with up to 10 to 1 aspect ratios, and grain size reduction, and is interpreted as a high strain ductile oblique-slip fault. 

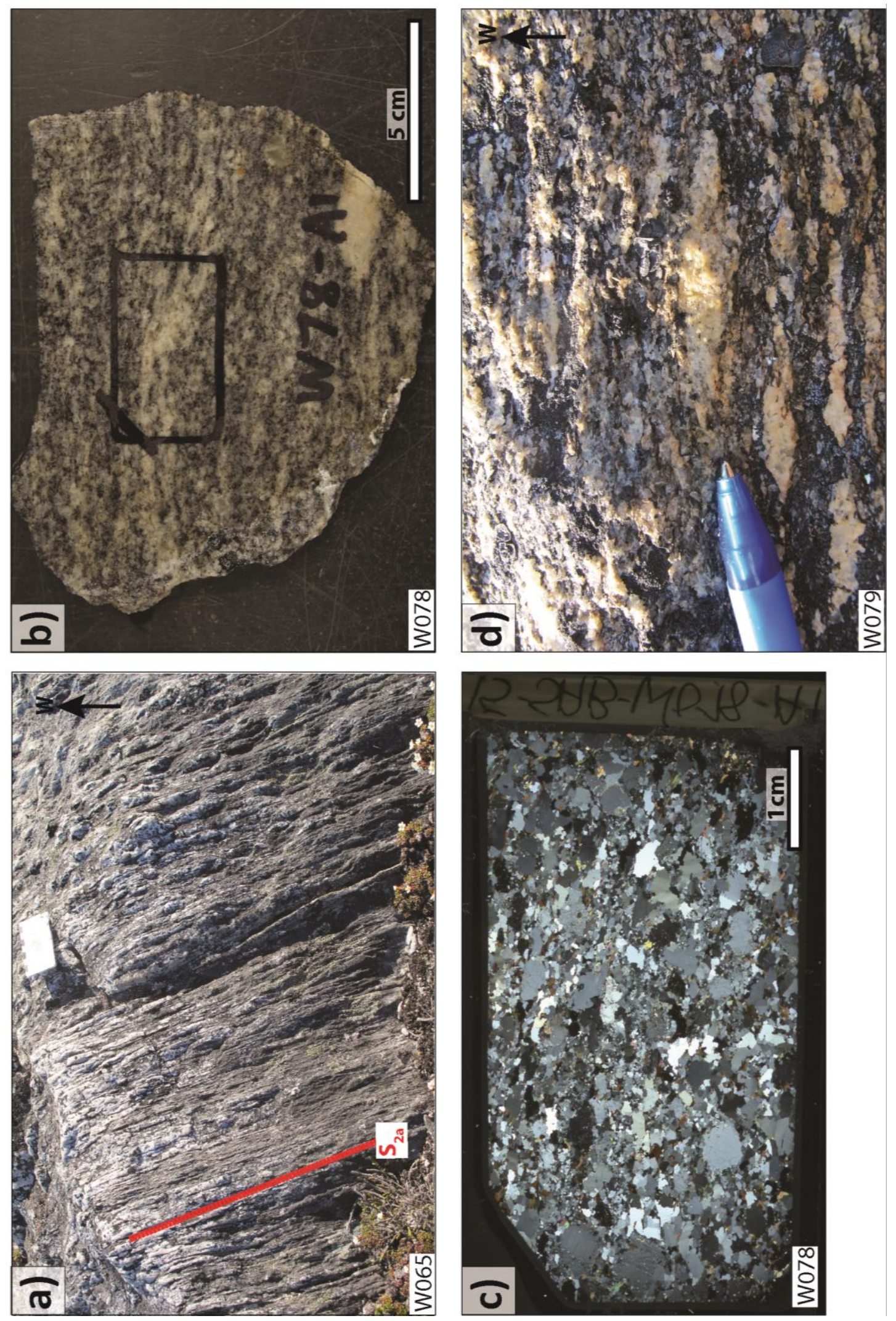
Figure 3.13. Photographs and photomicrographs of southern domain structures, Ptarmigan Fiord area, Hall Peninsula, Baffin Island, Nunavut. View in photomicrographs is of the motion plane, oriented parallel to $\mathrm{L}_{2 \mathrm{a}}$ and perpendicular to $\mathrm{S}_{2 \mathrm{a}}$. a) westward view of high-strain basement-cover contact at station L048 (station map; back pocket); b) strong transposition foliation in basement rocks $\sim 5 \mathrm{~m}$ away from basement-cover contact; c) slab of high-strain basement orthogneiss from station L051, $10 \mathrm{~m}$ away from basement-cover contact; d) thin section scan in cross-polarized light of high-strain granodiorite from station L051, where the trace of flattened quartz and feldspar grains and micas define a strong transposition foliation. 

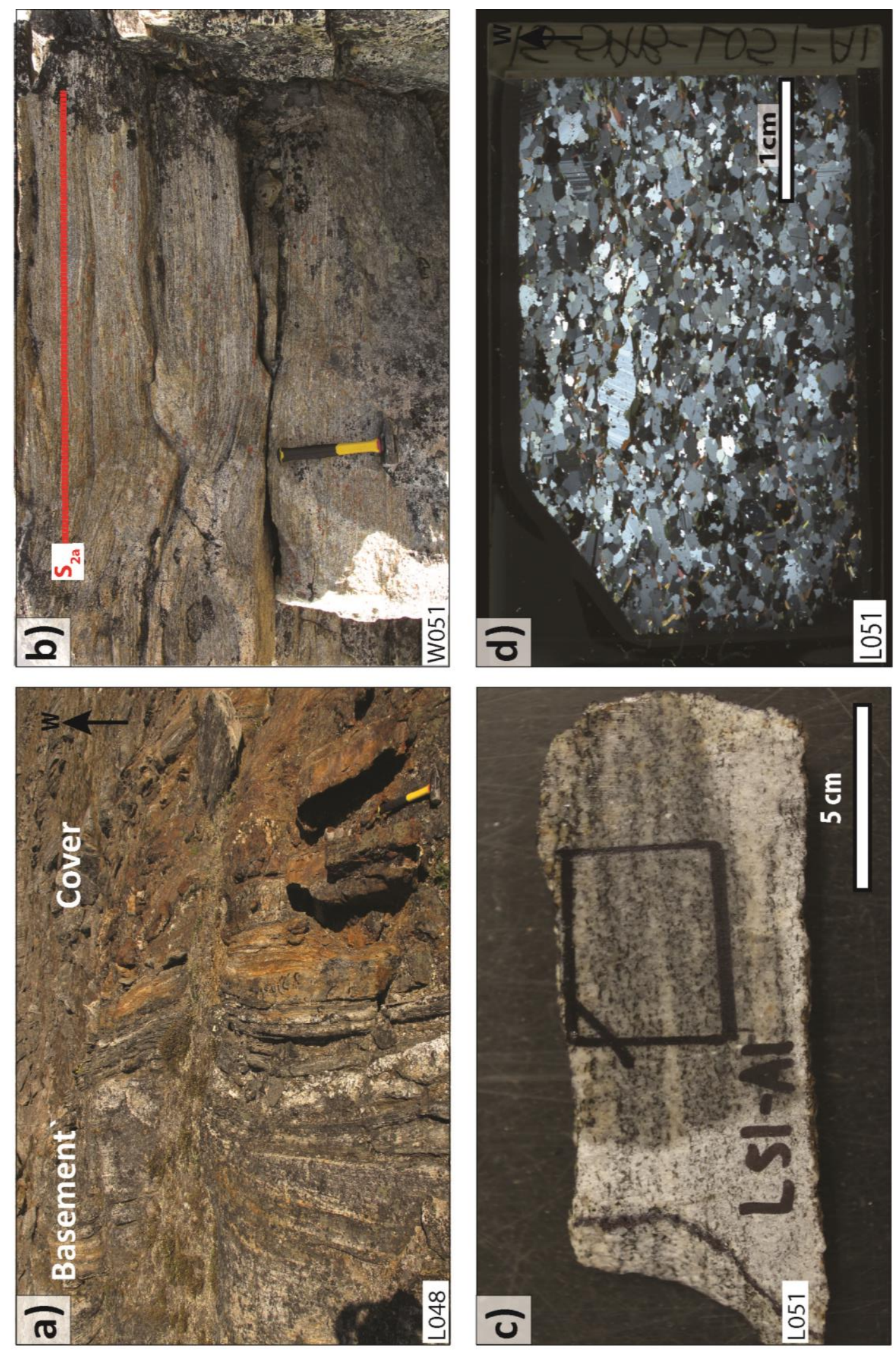
Figure 3.14. Panorama and outcrop photographs of Ptarmigan Fiord domain boundaries, Hall Peninsula of Baffin Island. a) northwestward view, facing $\sim 300^{\circ}$ azimuth, from a position on the base of the red rectangle labelled 'D269' on Map 2 (back pocket) of the boundary between northwest and southeast domains; basement rocks of 'B4', in the northwest domain, are juxtaposed against southeast domain basement-cover couplets $\left({ }^{\prime} \mathrm{B} 3\right.$ ' $+{ }^{'} \mathrm{C} 3$ ' and 'B2'+'C2') of the southeast domain. Basement of the northwest domain occurs in the far distance on the right side of the photograph, and southeast domain basement and cover occur in the foreground and left side of the photograph; b) eastward view of 'B4' basement (left of photograph) and 'C3' cover (right of photograph), separated by an $\sim \mathrm{E}-\mathrm{W}$-striking lake. The $\mathrm{T}_{3 \mathrm{c}}$ domain boundary is inferred to lie in the lake, between 'B4' and 'C3'; c) southward view of highly deformed and strained migmatitic cover rocks at station C103, evidenced by strongly attenuated and flattened quartzofeldspathic layers. 

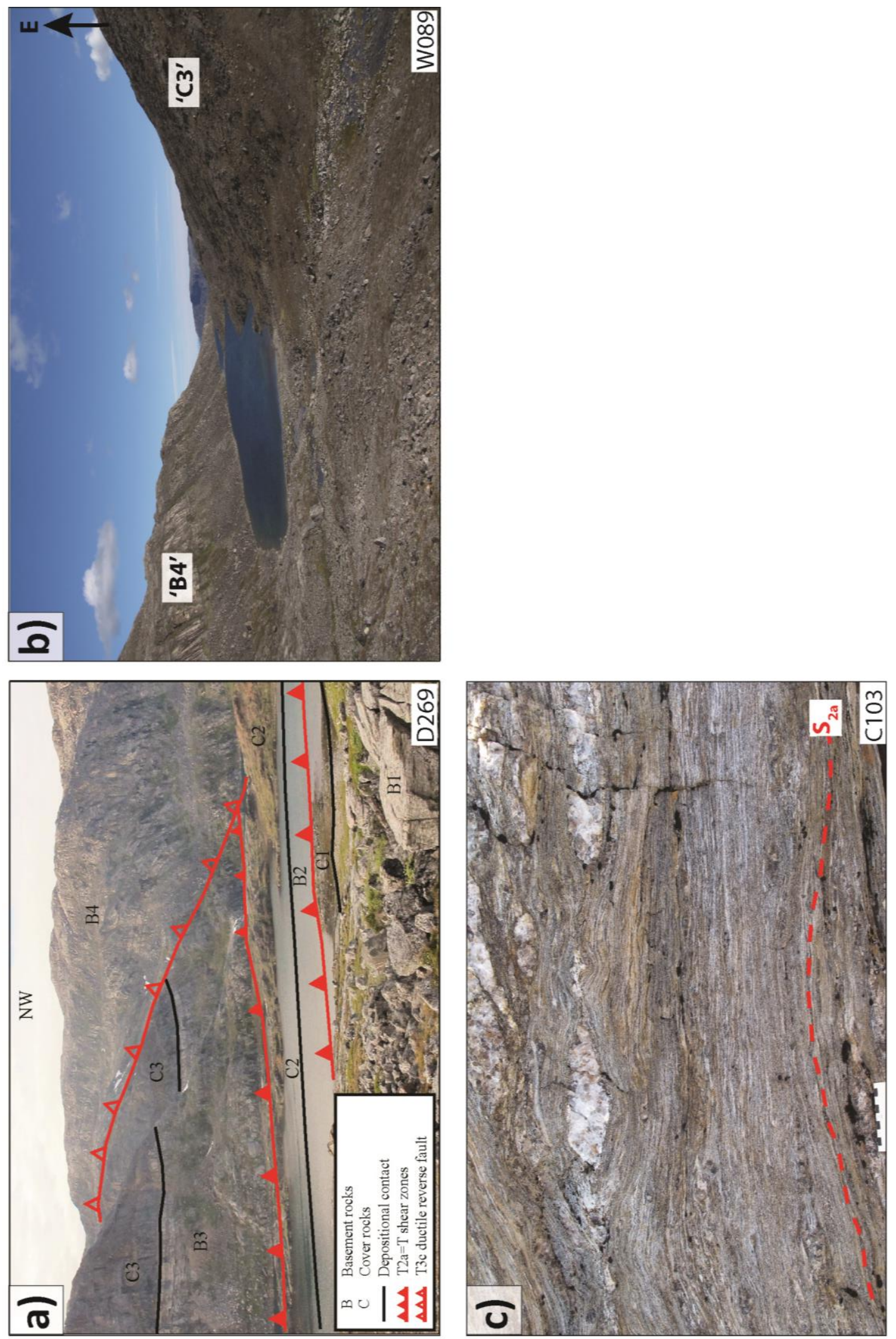
Figure 3.15. Photomicrographs of mineral grain boundary textures in oriented thin sections of basement monzogranite samples from Ptarmigan Fiord area, Hall Peninsula of Baffin Island (refer to the text for the significance of these grain boundary textures). View is of the motion plane, oriented parallel to $\mathrm{L}_{2 \mathrm{a}}$ and perpendicular to $\mathrm{S}_{2 \mathrm{a}}$. Photomicrographs are oriented with the down-dip direction towards the left of figure. Photographs are duplicated to allow the reader to view the annotated and unannotated versions of the photographs: a) 5-6 mm long recrystallized secondary quartz crystal (light yellow) with biotite inclusions, displaying curved grain boundaries with some lobate boundaries. The biotite grain hampered the outward growth of part of the light yellow quartz grain boundary, and is interpreted as a "pinning" microstructure; b) quartz and feldspar grains exhibit approximately equidimensional subhedral crystals with straight grain boundary contacts that make angles of $\sim 120^{\circ}$ at triple junctions, which can be interpreted as granoblastic texture. Abbreviations: Pl, plagioclase; Qz, quartz. 

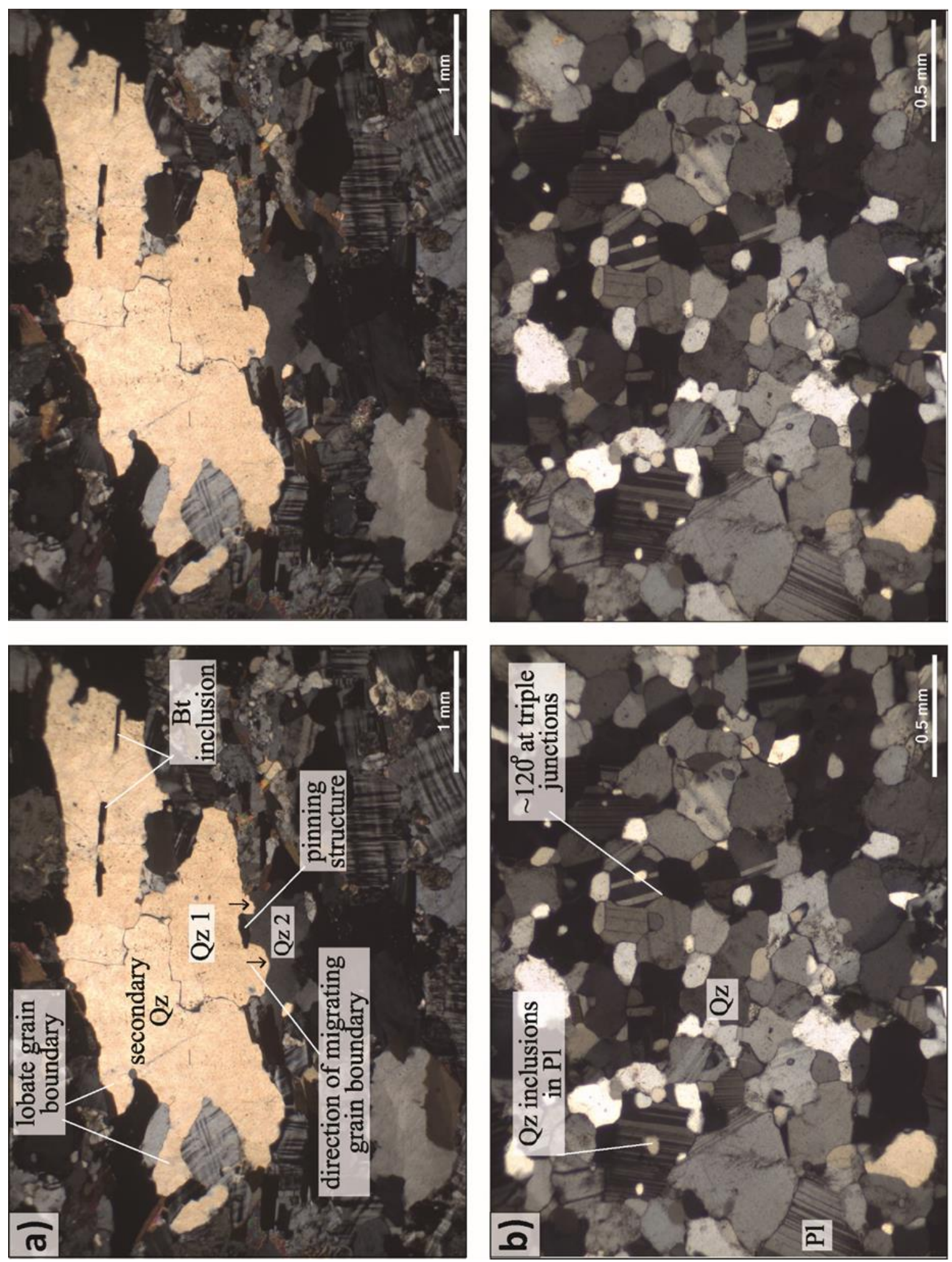
Figure 3.15 cont. Photomicrographs showing grain boundary textures from oriented thin sections of basement monzogranite samples from Ptarmigan Fiord area, Hall Peninsula of Baffin Island (refer to the text for the significance of these grain boundary textures). View is of the motion plane, oriented parallel to $\mathrm{L}_{2 \mathrm{a}}$ and perpendicular to $\mathrm{S}_{2 \mathrm{a}}$. Photomicrographs are oriented with the down-dip direction towards the left of figure: c) 'window' structure in center of view where the black quartz grain (Qz 1) is interpreted to have a mobile grain boundary advancing into the light grey quartz grain $(\mathrm{Qz} 2)$, between the two impeding biotite grains (Bt 1 and $\mathrm{Bt}$ 2); d) Note: relative to figure $\mathbf{c}$, the thin section has been rotated 45 degrees clockwise to show extinction details. There is sweeping undulose extinction in flattened quartz grains suggesting post-annealing deformation. Deformation twins are observed in a $0.5 \mathrm{~mm}$ long plagioclase grain, which is interpreted as post-annealing deformation. Abbreviations: Bt, biotite; Ms, muscovite; Qz, quartz. 

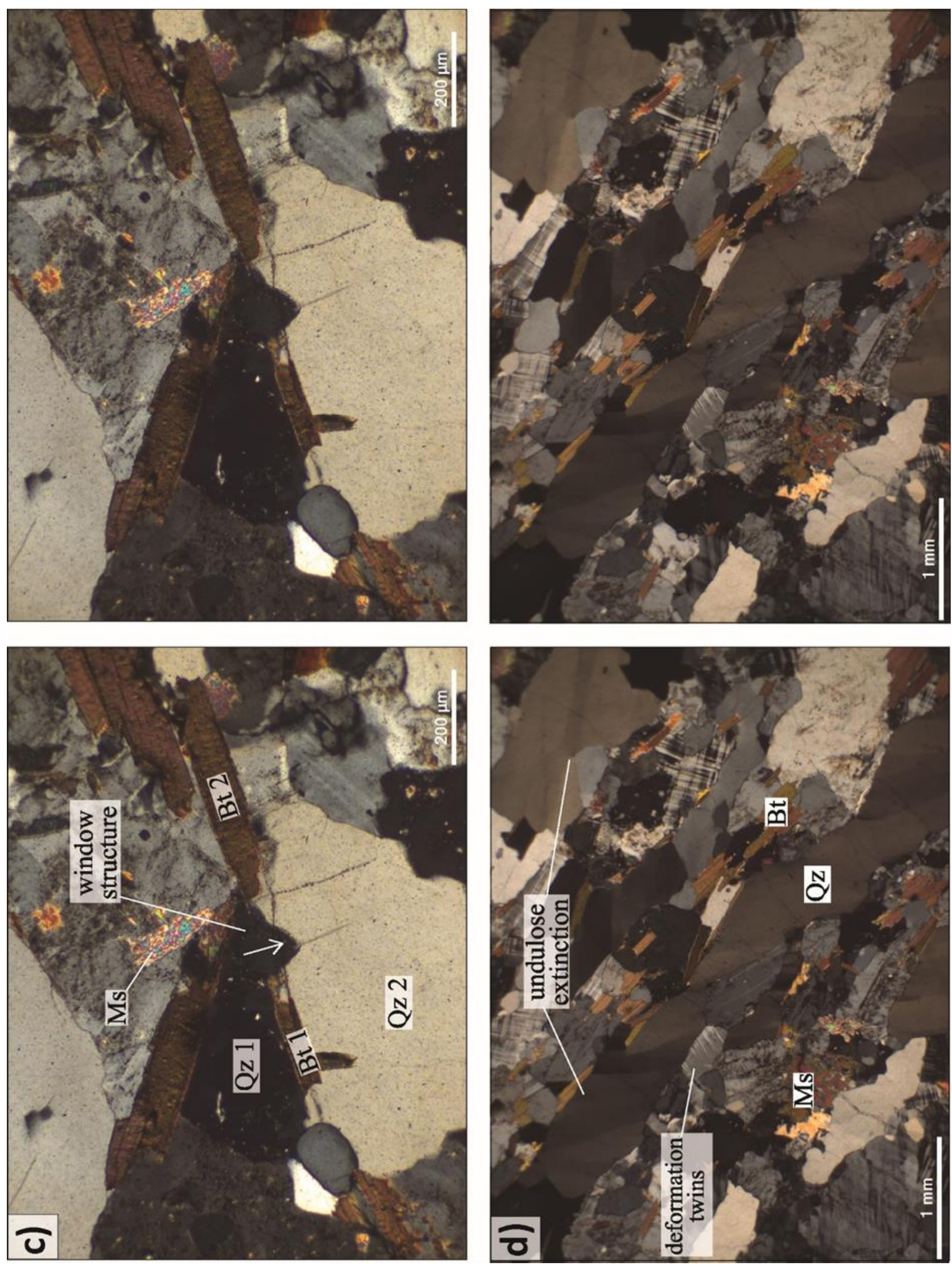
Figure 3.16. Representative examples showing variations of progressive strain increase in basement biotite hornblende monzogranite (i.e. a, c, e \& g are photographs and b, d, f $\& \mathrm{~h}$ are photomicrographs in cross-polarized light) from the southeast domain. View is of the motion plane, oriented parallel to L2a and perpendicular to S2a: a-b) sample C039, from autochthonous basement 'B0' (Map 1; back pocket), has flattened aggregates of coarse-grained alkali feldspar, platy minerals and moderately flattened (i.e. up to 5 to 1 aspect ratio of grains) quartz and feldspar that are aligned in the $\mathrm{S}_{2 \mathrm{a}}$ foliation. The percentage of matrix is higher in d), f) and h) relative to b), and this sample is considered to only contain the lowest strained 'background' foliation; c-d) sample W018 from the base of basement slice 'B1' is a higher strain equivalent of sample C039. There appears to be a $\sim 10-20 \%$ reduction in grain size in the basement monzogranite, within 2 meters of the contact, compared to that from station C039 in 'B0', as well as the development of protomylonitic fabrics with a well-defined stretching lineation; e-f) sample C054 collected from a 5-10 m thick mylonite zone at the base of basement slice 'B2' is a higher strain equivalent of sample W018. This sample of mylonite contains a strong $\mathrm{S}_{2 \mathrm{a}}$ foliation defined by attenuated quartz crystals and alignment of micas, a strong lineation, and a further $\sim 10 \%$ reduction of grain size relative to that shown in c \&d; $\mathbf{g - h}$ ) sample C057 collected from the $\sim 5 \mathrm{~m}$ thick mylonite zone at the base of basement slice 'B3' is an example of the highest strained basement rock in the southeast domain. There has been an additional $\sim 5-10 \%$ reduction of grain size relative to sample C054, the sample contains a strong L2a, and flattened quartz and feldspar grains define a strong S2a. 

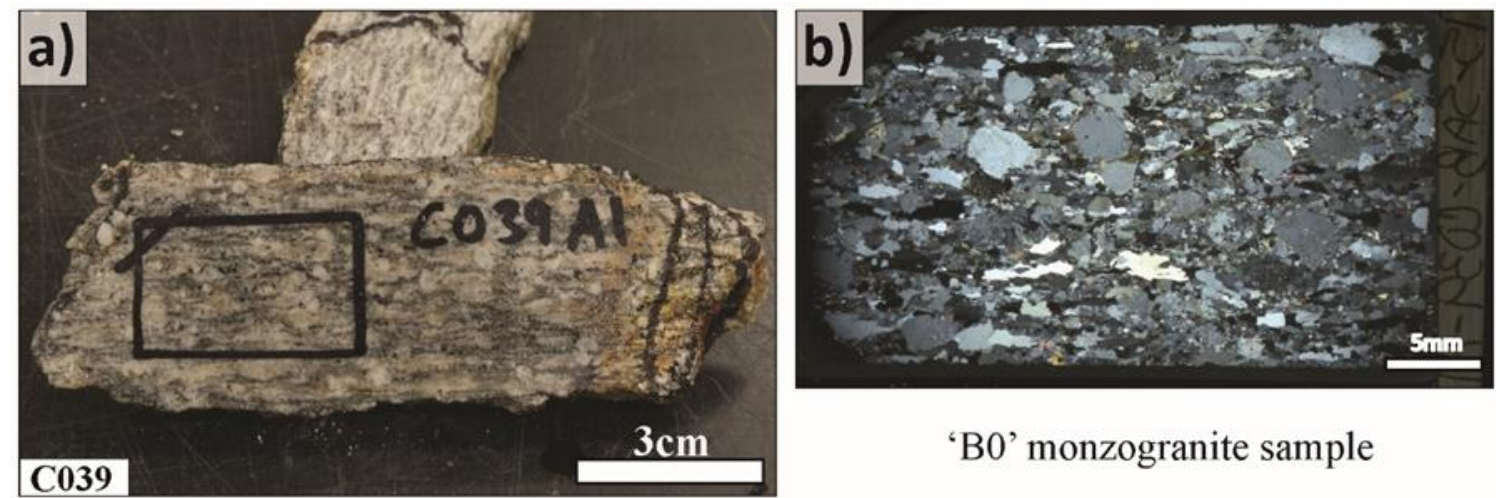

'B0' monzogranite sample
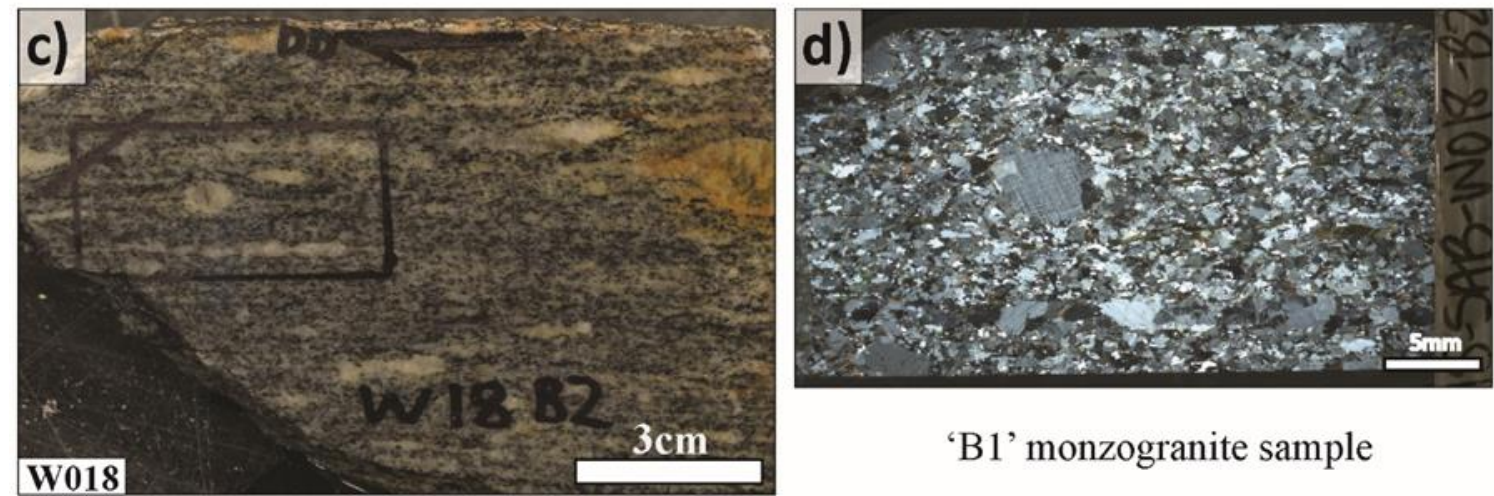

'B1' monzogranite sample
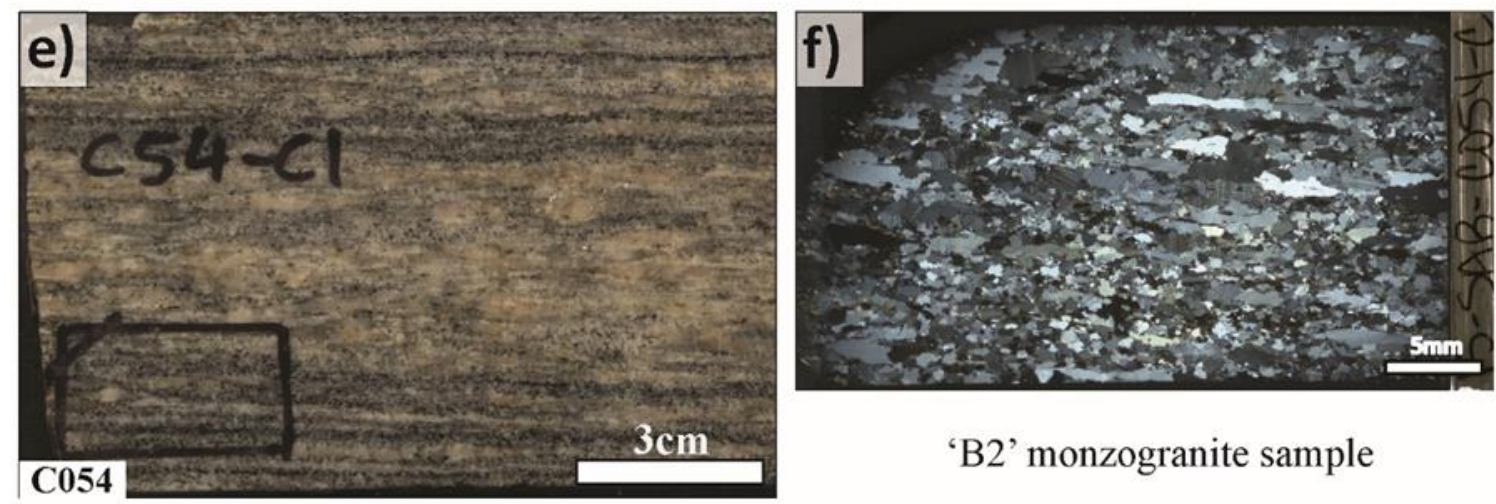

'B2' monzogranite sample
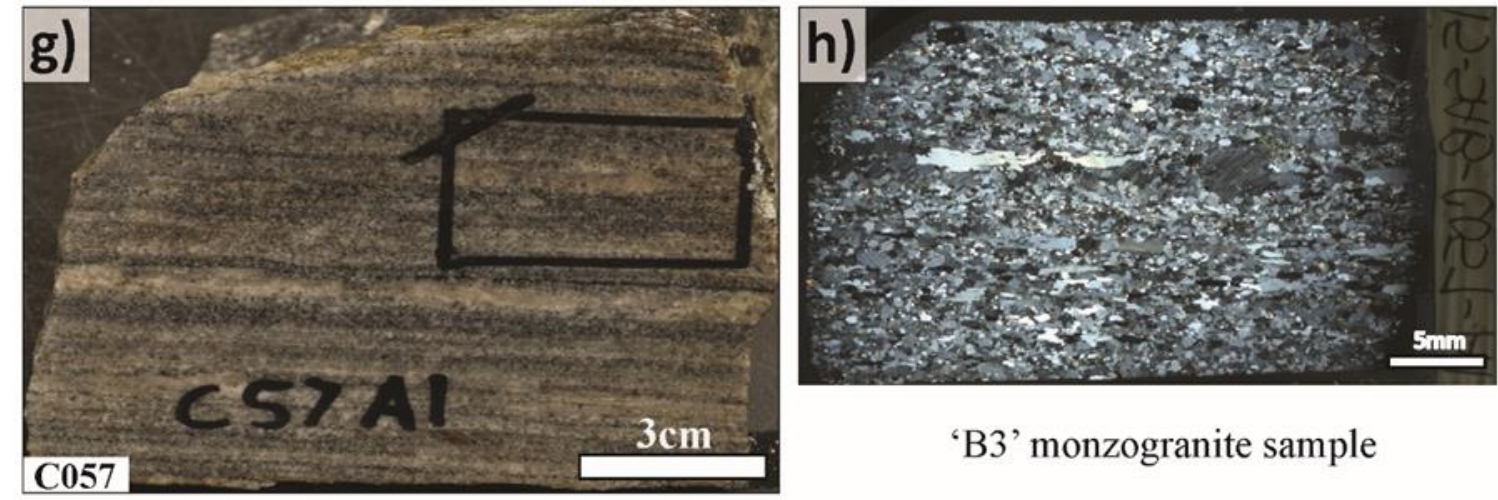

'B3' monzogranite sample 
Figure 3.17. Photographs and photomicrographs of basement monzogranite from station C055 in 'B2' (Station Map; back pocket), located near the center of the 'B2' basement sheet. View in photomicrographs is of the motion plane, oriented parallel to $\mathrm{L}_{2 \mathrm{a}}$ and perpendicular to $\mathrm{S}_{2 \mathrm{a}}$ : a) outcrop contains foliation $\mathrm{S}_{2 \mathrm{a}}$ foliation defined by the alignment of 2-4 millimetre-thick resistive quartzofeldspathic layers; b-d) In hand specimen and thin section, samples contain moderate to high shear strain evidenced by S-C fabric development, and strain shadows around alkali-feldspar porphyroclasts. The orientation of flattened quartz and feldspar (up to 5 to 1 aspect ratio of grains) and micas define the composite $\mathrm{S}_{2 \mathrm{a}}$ in thin section. Sample C055 (b-d) looking $\sim \mathrm{NE}$, of sigma ( $\sigma$ )-type porphyroclast in 'B2' monzogranite showing counter-clockwise, apparent normal (top-tothe-northwest) sense of shear. 

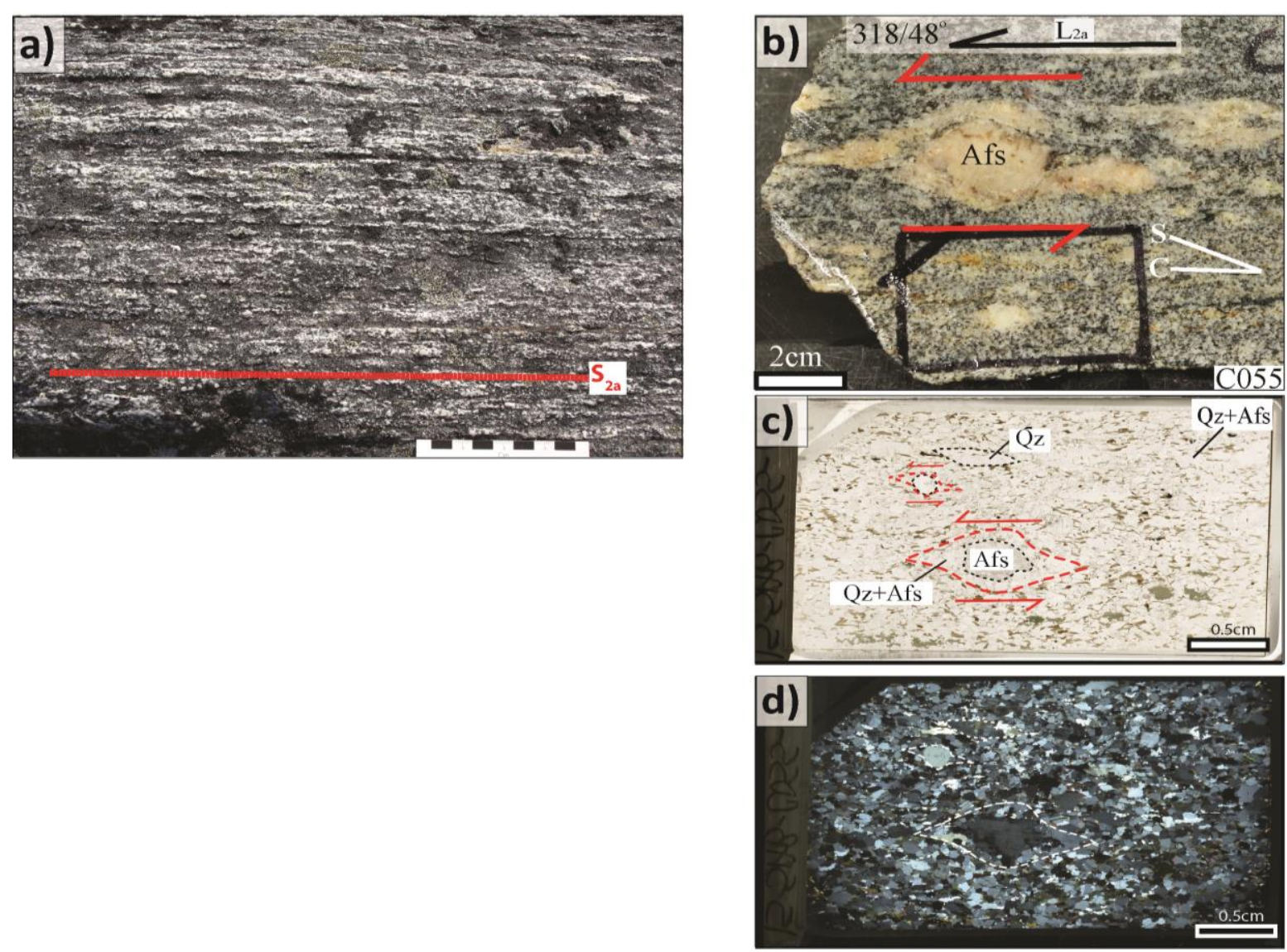
Figure 3.18. Station $\mathrm{C} 036$ is located $\sim 1 \mathrm{~km}$ east of the 'B0' basement-cover contact, and is interpreted to be from the deepest exposed structural level in the southeast domain: a) monzogranite from station C036 contains alternating centimetre-thick layers of concordant biotite-rich and biotite-poor material, which define a moderate $\mathrm{S}_{2 \mathrm{a}}$ foliation; b) in thin section, coarse-grained $(\sim 5-15 \mathrm{~mm})$ rounded porphyroclasts of alkali feldspar are aligned within roughly planar aggregates which are parallel to a shape preferred orientation of finer-grained matrix biotite, muscovite, and flattened quartz and feldspar (up to 3 to 1 aspect ratio of grains), defining a weak-to-moderate $\mathrm{S}_{2 \mathrm{a}}$ foliation. 


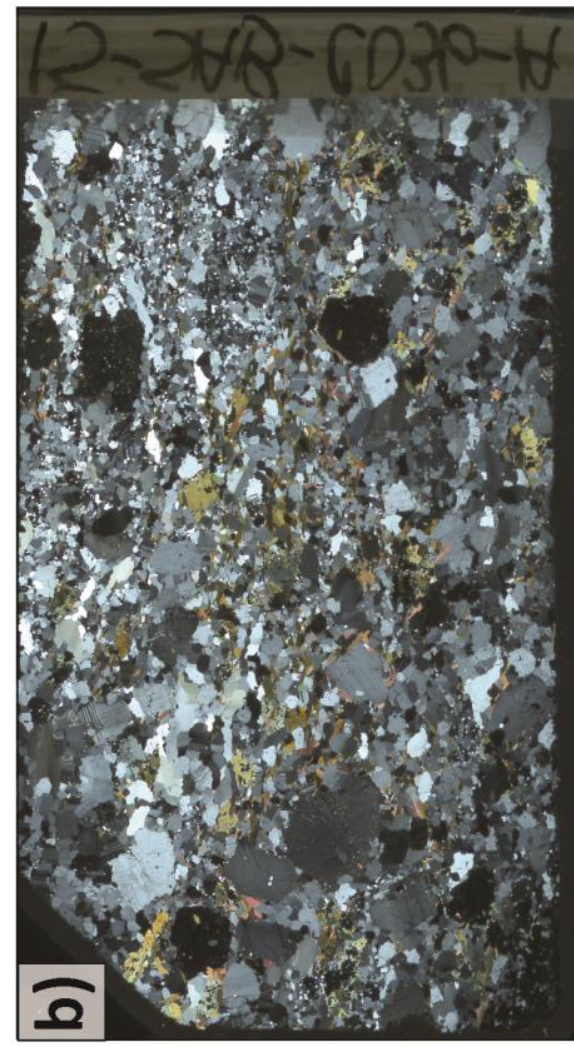

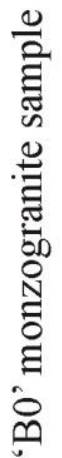

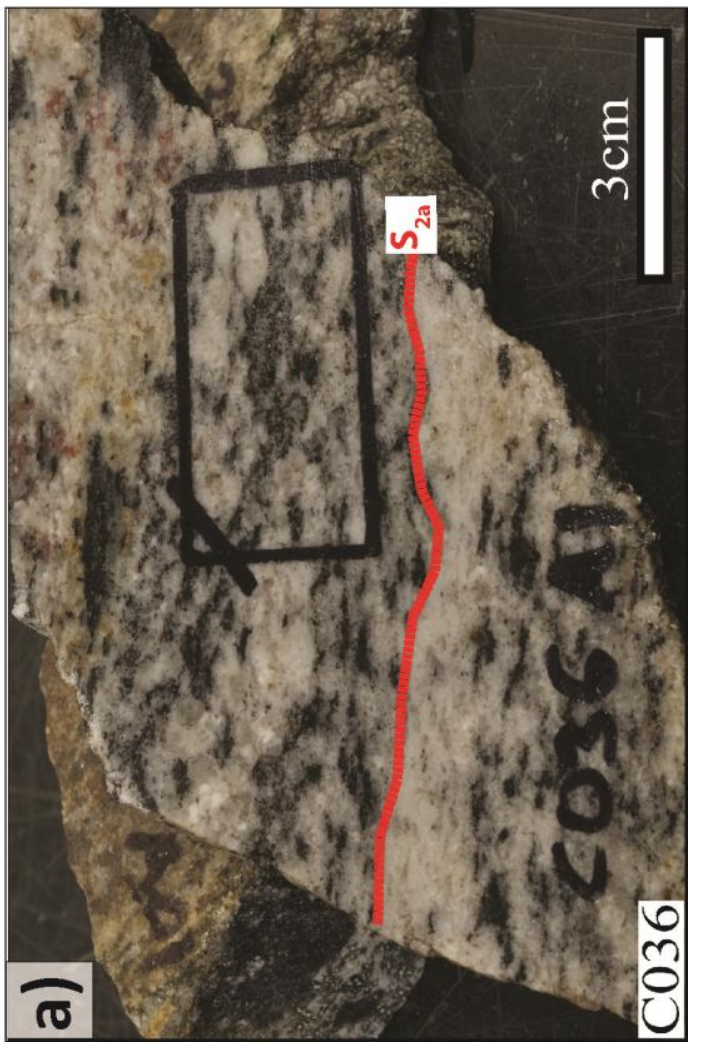


Figure 3.19. Representative examples of progressive strain in upper basement contacts from the southeast domain, Ptarmigan Fiord area, Hall Peninsula of Baffin Island. View is of the motion plane, oriented parallel to $\mathrm{L}_{2 \mathrm{a}}$ and perpendicular to $\mathrm{S}_{2 \mathrm{a}}$. The downdip direction toward the left of figure: a-d) samples from stations C099 and C060 (Map 2; back pocket) exhibiting mylonitic fabrics, strong L $2 a_{2}$ stretching lineations, and the trace of strong $\mathrm{S}_{2 \mathrm{~s}}$ foliations defined by the alignment of micas, flattened quartz and feldspar grains, and 5-10 millimetre-thick quartzofeldspathic layers. 

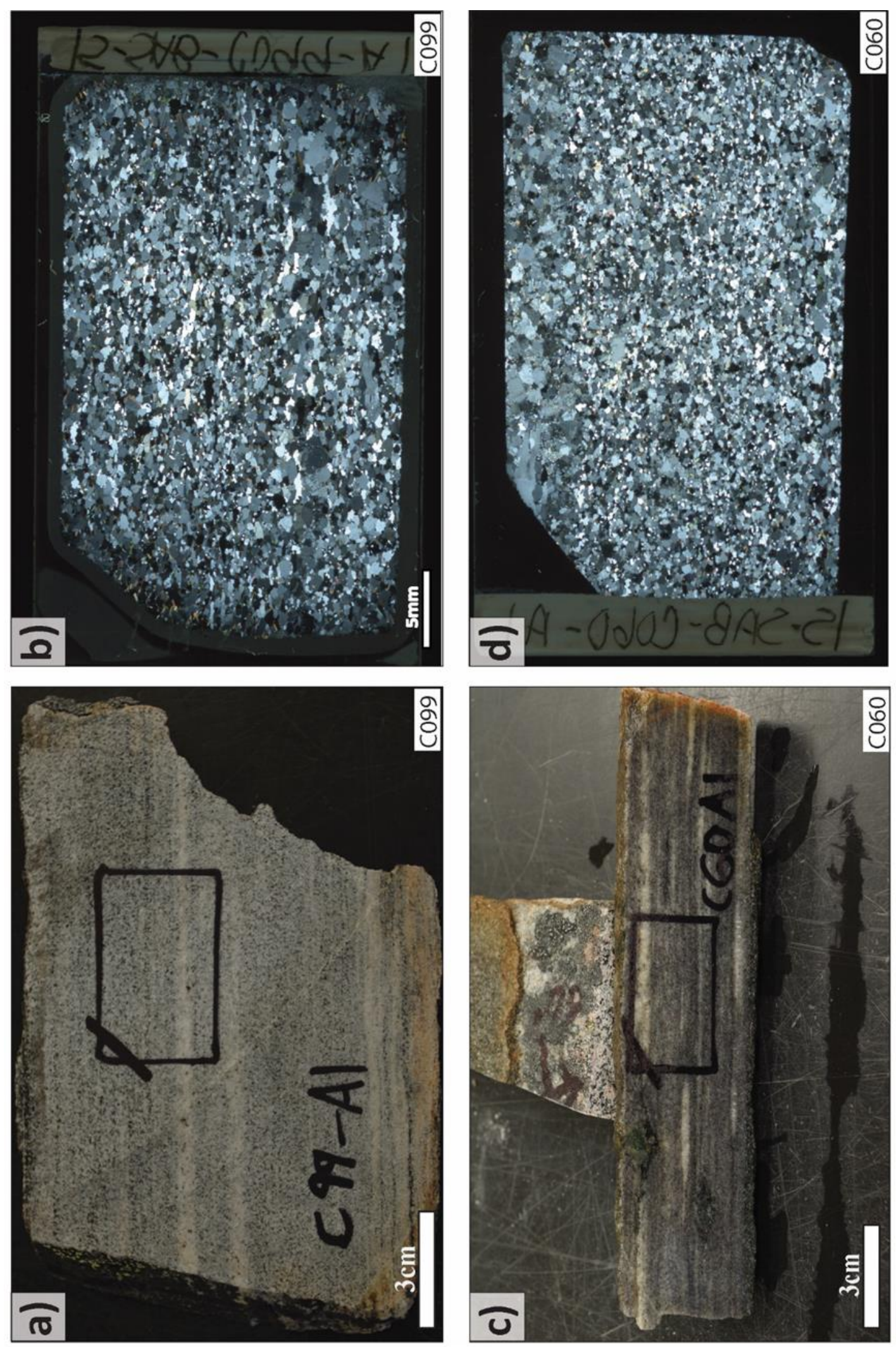
Figure 3.20. Representative examples of progressive strain increase in basement biotite hornblende monzogranite (a, c, e \& g are photographs and b, d, f \& h are photomicrographs in cross-polarized light) from the northwest domain. View is of the motion plane, oriented parallel to $\mathrm{L}_{2 \mathrm{a}}$ and perpendicular to $\mathrm{S}_{2 \mathrm{a}}$. Sample C089 (a \& b) from the base of basement imbricate 'B4' (Map 1; back pocket) is an example of a moderately-strained monzogranite sample with the trace of a penetrative $\mathrm{S}_{2 \mathrm{a}}$ foliation defined by alignment of biotite, that has undergone annealing. It contains $1-3 \mathrm{~mm}$ diameter quartz and feldspar minerals that exhibit a roughly granoblastic texture, with $120^{\circ}$ triple junctions between grain boundaries of equidimensional subhedral crystals. In the outcrop, the rock contains a well-defined stretching lineation. Sample W010 (c \& d) from the base of basement slice 'B5' is high strain and contains a well-developed $\mathrm{S}_{2 \mathrm{a}}$ foliation defined by biotite and attenuated quartzofeldspathic material, and a strong lineation. In thin section, this sample has weak granoblastic texture and lobate grain boundaries interpreted as annealing textures. Sample L092 (e \& f), from a mylonite zone at the base of basement slice 'B6', is a higher strained equivalent of sample W010. It contains a strong C-foliation defined by alignment of micas and flattened quartz, an Sfoliation defined by the long axis of feldspar porphyroblasts and attenuated and pulledapart quartzofeldspathic material, a strong stretching lineation, and a $\sim 10 \%$ reduction of matrix grain size compared to sample W010. Sample L092, looking SE, contains sigma $(\sigma)$-type K-feldspar porphyroclasts showing clockwise, apparent reverse (top-to-thesouthwest) sense of shear. Sample L087 ( $\mathbf{g} \boldsymbol{\&} \mathbf{~ h})$ collected $\sim 400 \mathrm{~m}$ from the inferred ductile shear zone at the base of the 'B7' basement imbricate. The sample contains a foliation defined by alignment of biotite. 

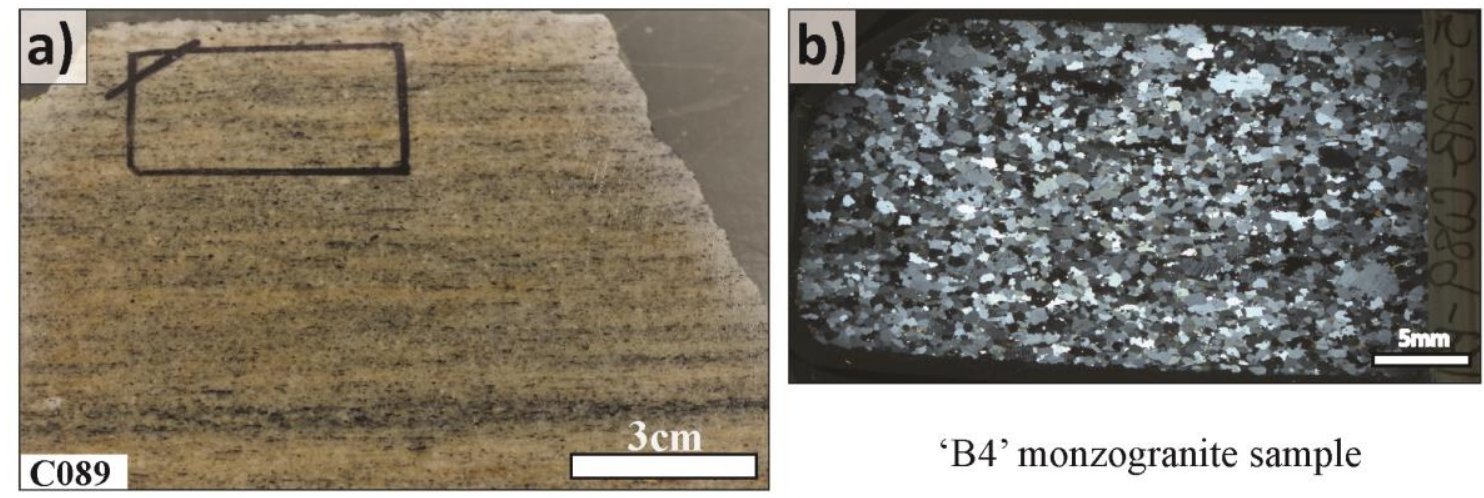

'B4' monzogranite sample
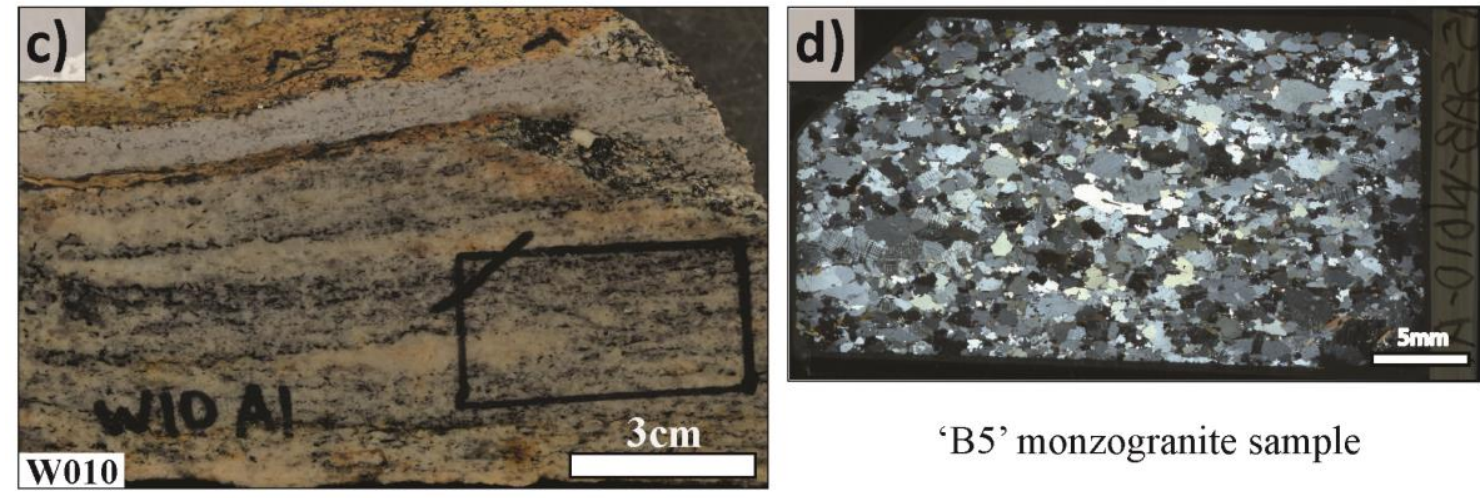

'B5' monzogranite sample
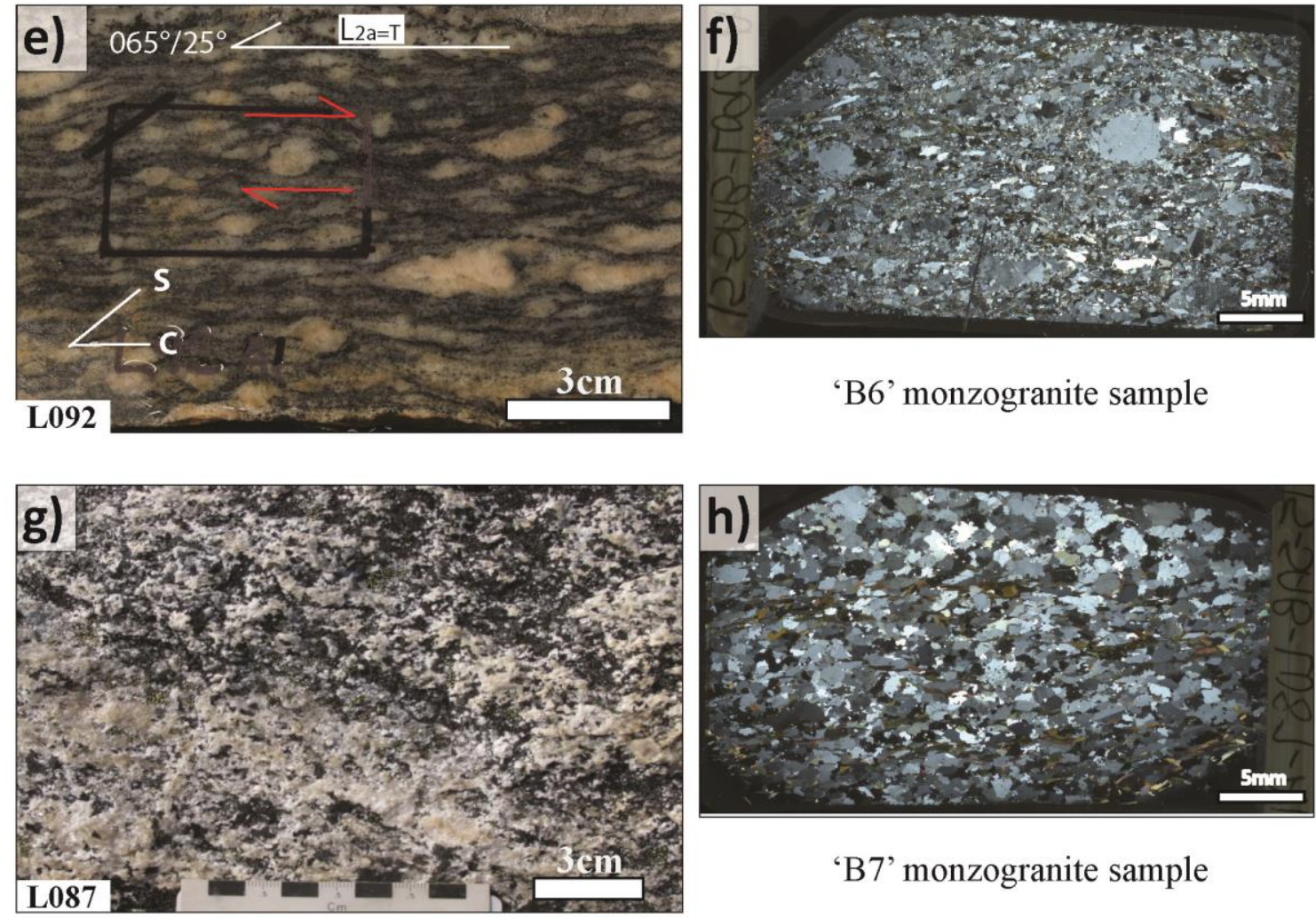

'B7' monzogranite sample 
Figure 3.21. Representative examples of structures used to determine shear sense in basement rocks from shear zones at the bases of repeated basement sheets in the southeast domain. Shear sense indicators in gneissic basement biotite hornblende monzogranite rocks (i.e. a \& d \& g are photographs; b \& e are photomicrographs in plainpolarized light; and c \& f are photomicrographs in polarized light). View is of the motion plane, oriented parallel to $\mathrm{L}_{2 \mathrm{a}}$ and perpendicular to $\mathrm{S}_{2 \mathrm{a}}$. Sample W018 $(\mathbf{a}-\mathbf{c})$, looking NE, of sigma $(\sigma)$-type porphyroclasts showing counter-clockwise, apparent obliquesinistral sense of shear in 'B1' basement. Station C061 (d - f), looking $\sim \mathrm{N}$, of sigma $(\sigma)$ type porphyroclast within 'B2' monzogranite showing counter-clockwise, apparent oblique-sinistral sense of shear. Station W024 (g), sigma ( $\sigma)$-type porphyroclast in 'B3' basement granodiorite, parallel to a moderately west-plunging lineation on a steeply southwest-dipping foliation, showing apparent oblique-sinistral sense of shear. Abbreviations: Afs, alkali-feldspar; Amp, amphibole; Bt, biotite; Qz, quartz; C, C-planes (cisaillement planes); S, S-planes (schistosité planes). 

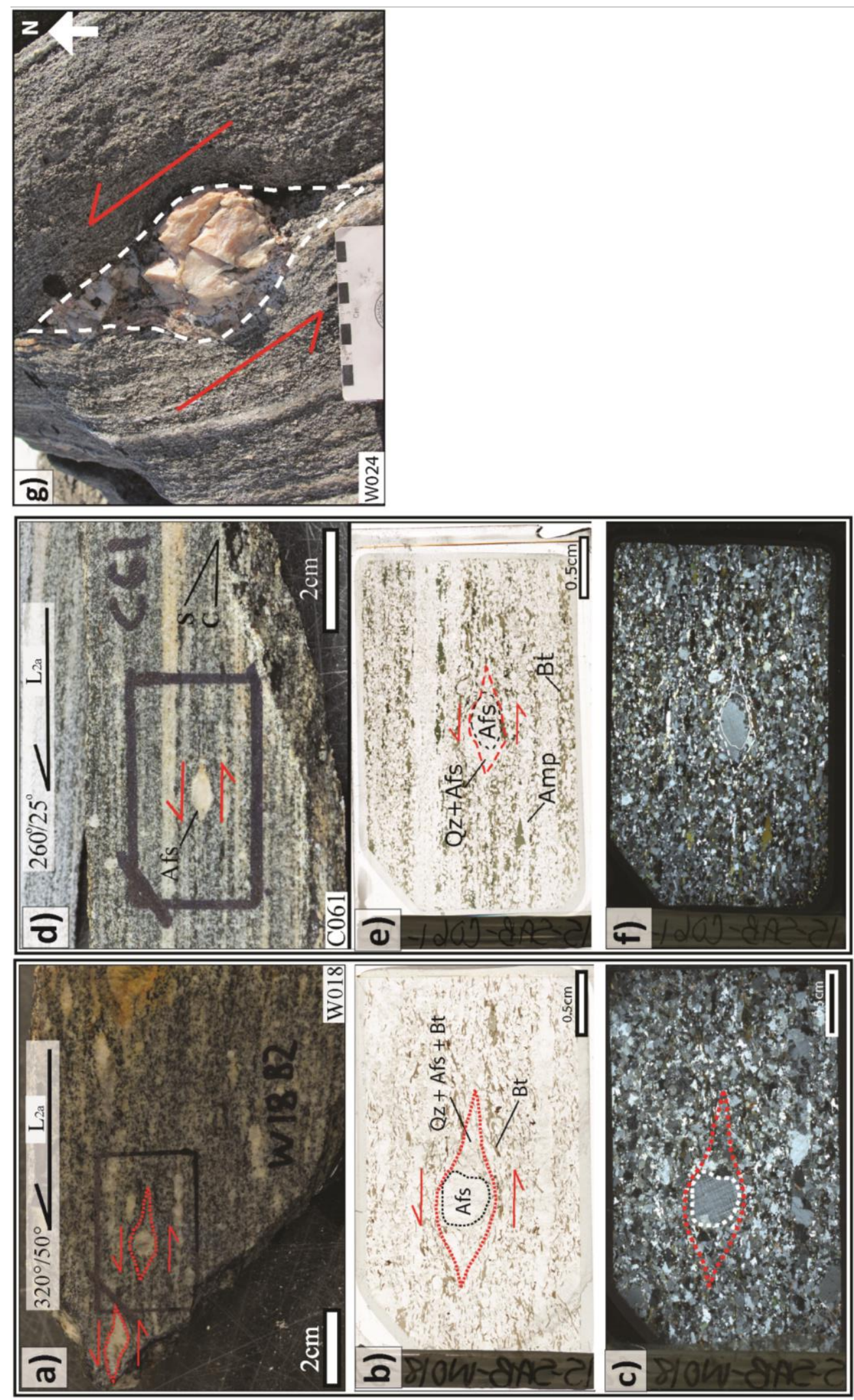
Figure 3.22. Photograph of representative examples of structures used to determine shear sense in basement rocks from shear zones at the bases of repeated basement sheets in the northwest domain of the Ptarmigan Fiord area: a) Sample W060 looking N, of sigma $(\sigma)$-type K-feldspar porphyroclast showing clockwise, apparent oblique-dextral sense of shear. 


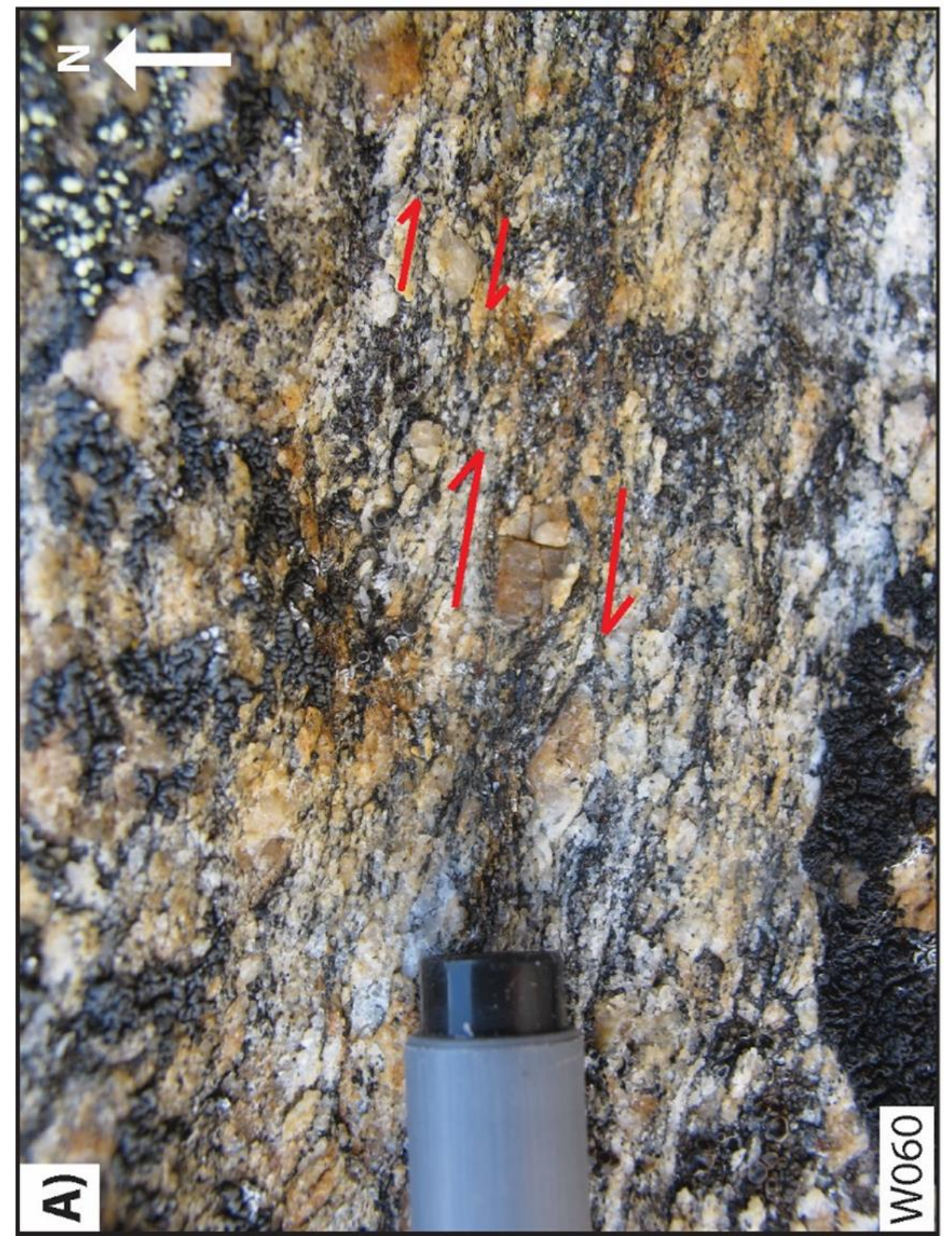


Table 3.1: Summary of structures and thermal regime for three generations of structures in the Ptarmigan Fiord Area, Hall Peninsula, Baffin Island, Nunavut. 
Table 3.1: Summary of structures and thermal regime for three generations of structures in the Ptarmigan Fiord Area, Hall Peninsula, Baffin Island, Nunavut.

\begin{tabular}{|c|c|c|c|c|c|c|c|c|}
\hline \multirow[b]{2}{*}{ Age } & \multirow[b]{2}{*}{ Stage } & \multicolumn{7}{|c|}{ Ptarmigan Fiord Area Structures } \\
\hline & & $\begin{array}{l}\text { Thermal } \\
\text { Regime }\end{array}$ & Structure & Southeast Domain & & Northwest Domain & Northern Domain & Southern Domain \\
\hline \multirow{6}{*}{$\begin{array}{l}\frac{0}{2} \\
\frac{0}{20} \\
\frac{0}{20} \\
\frac{0}{0} \\
\frac{0}{0} \\
\frac{0}{0}\end{array}$} & 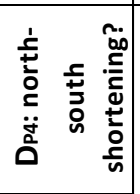 & & \begin{tabular}{|l|} 
Fa?: Gentle bend in the NE-SW \\
to N-S trending basement-cover \\
contacts in the northwest \\
domain and potentially T3C \\
domain boundary shear zone
\end{tabular} & NA & $\begin{array}{l}\text { Map-scale gentle } \\
\text { imbricates and } p\end{array}$ & $\begin{array}{l}\text { le bend in } \sim \mathrm{N}-\mathrm{S} \text { striking basement - cover } \\
\text { potentially the northwest domain boundary }\left(\mathrm{T}_{4}\right) \text {. }\end{array}$ & NA & NA \\
\hline & 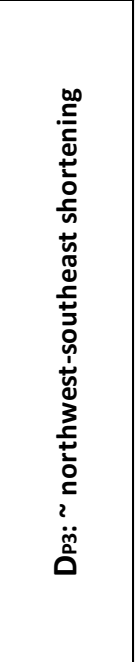 & 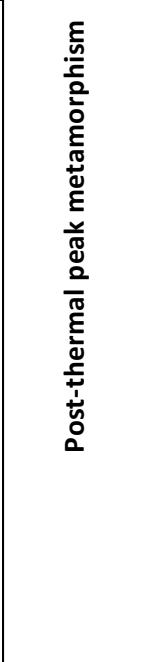 & $\begin{array}{l}\text { T3c: Reverse-sense ductile fault } \\
\text { that truncates southeast domain } \\
\text { Fab: map scale steeply inclined } \\
\text { folds with SW-striking, NW- } \\
\text { dipping axial surfaces that } \\
\text { plunge steeply to the W, } \\
\text { believed to be gentle folds } \\
\text { based on the map scale folding } \\
\text { of basement-cover imbricates } \\
\text { S3a: Crenulation cleavage } \\
\text { F3a: upright - steeply inclined, } \\
\text { ESE-dipping folds that are sub- } \\
\text { horizontally plunging to the SSW } \\
\text { and NNE. Are typically open- } \\
\text { gentle folds }\end{array}$ & 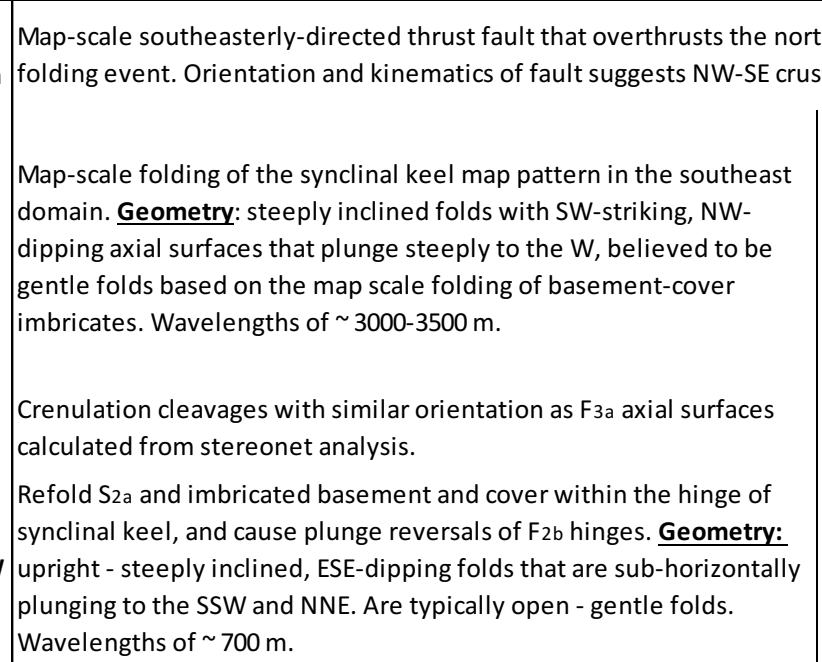 & $\begin{array}{l}\text { thwestern domai } \\
\text { istal shortening. }\end{array}$ & in onto the southeast domain following the $F_{3 b}$ & $\begin{array}{l}\text { See S3a description for southeast domain. } \\
\text { F3a-style folds with similar orientation as F3a in } \\
\text { southeast domain. Geometry: upright - steeply } \\
\text { inclined, NW-dipping folds that sub-horizontally } \\
\text { plunging to the NE. Are typically open - gentle } \\
\text { folds. Wavelengths of } \sim 800 \mathrm{~m} \text {. }\end{array}$ & $\begin{array}{l}\text { SW extent of T3c fault is unknown. Might } \\
\text { overthrust northwest domain onto south } \\
\text { domain? }\end{array}$ \\
\hline & & 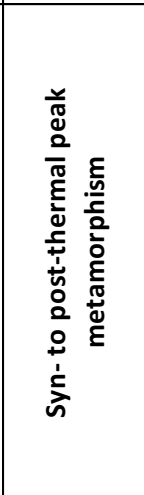 & 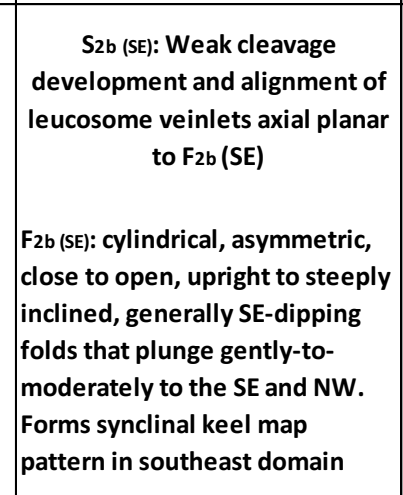 & $\begin{array}{l}\text { Cleavage defined by weak alignment of platy minerals and } \\
\text { leucosome veinlets axial planar to F2b (SE). Only seen in psammitic to } \\
\text { pelitic cover rocks in the map scale F2b (SE) hinges. } \\
\text { Fold S2a, imbricated basement and cover, and shear zones in the } \\
\text { southeast domain. Geometry: cylindrical, asymmetric, close to open, } \\
\text { upright to steeply inclined, generally SE-dipping folds that plunge } \\
\text { gently-to-moderately to the SE and NW. Forms synclinal keel map } \\
\text { pattern in eastern domain with } 1400 \mathrm{~m} \text { wavelength, and minor folds } \\
\text { within the hinge with } \sim 500 \mathrm{~m} \text { wavelengths. }\end{array}$ & \begin{tabular}{|c|} 
S2b (NW): Weak \\
cleavage \\
development \\
axial planar to \\
F2b (NW)
\end{tabular} & $\begin{array}{l}\text { Cleavage defined by weak alignment of platy } \\
\text { minerals axial planar to in psammitic and pelitic } \\
\text { rocks, and flattened quartz in basement rocks. } \\
\\
\text { Fold } S_{22} \text {, imbricated basement and cover, and } \\
\text { shear zones in the northwest domain. } \\
\text { Geometry: Gently inclined folds with } W \text { - } \\
\text { dipping fold axes that plunge gently to the } \\
\text { west, and are typically open folds. Outcrop } \\
\text { scale folds have wavelengs of } \sim 1-5 \mathrm{~m} \text {, while } \\
\text { cliff face folds have wavelengths of } \sim 50-300 \mathrm{~m} \text {. }\end{array}$ & NA & $\begin{array}{l}\text { F22 (S): Fold S2a, imbricated basement and } \\
\text { cover, and shear zones in the southern } \\
\text { domain. Similar geometry as F2b (SE), but } \\
\text { opposing axial surface strike. }\end{array}$ \\
\hline & & 冞 & $\begin{array}{l}\text { La: Tectonic mineral stretching } \\
\text { and elongate growth lineation } \\
\text { S2a: Transposition foliation }\end{array}$ & \multicolumn{5}{|c|}{$\begin{array}{l}\text { Occur in all domains. Alignment of faserkiesel knots in pelitic rocks and quartz rodding and elongate feldspar in basement rocks. } \\
\text { Occur in all domains. Composite transposition foliation (S2a) defined by the alignment of compositional layering, gneissic banding in basement rocks, basement-cover contacts, thermal-peak metamorphic minerals, leucosome } \\
\text { veins and pods, axial surfaces of mature folds (F2a). Higher strained equivalents of S2a, in the form of ductile shear zones and mylonite, are localized at bases of basement-cover couplets (TP), at the upper non-conformable } \\
\text { basement contacts, and within individual imbricated basement slices. }\end{array}$} \\
\hline & & 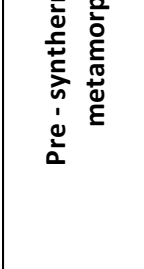 & \begin{tabular}{l|} 
F2a: Mature intrafolial rootless \\
isoclinal folds
\end{tabular} & $\begin{array}{l}\text { Rootless recumbent isoclinal folds in basement and cover units at } \\
\text { scales of } \sim 10 \text { to } 50 \mathrm{~cm} \text {. Layers that are folded include compositional } \\
\text { layering (SO) and quartzofeldspathic veins. Axial planes are parallel to } \\
\text { S2a and fold hinges are oriented parallel to the penetrative } \\
\text { extension lineations (L2a), making these folds transposition } \\
\text { deformation age. }\end{array}$ & \begin{tabular}{|l} 
F2a: Intrafolial \\
rootless \\
isoclinal folds, \\
and sheath \\
folds.
\end{tabular} & $\begin{array}{l}\text { Rootless recumbent isoclinal folds in basement } \\
\text { and cover units at scales of } \sim 10 \text { to } 50 \mathrm{~cm} \text {, with } \\
\text { same morphology as those in the southeast } \\
\text { domain. The fold axes of sheath folds, with } \sim 5 \\
\text { to } 20 \mathrm{~cm} \text { elliptical sections or nested rings, are } \\
\text { oriented parallel to the penetrative extension } \\
\text { lineations. }\end{array}$ & $\begin{array}{l}\text { Rootless recumbent isoclinal folds in basement } \\
\text { and cover units at scales of } \sim 10 \text { to } 50 \mathrm{~cm} \text {, with } \\
\text { same morphology as those in the southeast } \\
\text { domain. }\end{array}$ & $\begin{array}{l}\text { Rootless recumbent isoclinal folds in } \\
\text { basement and cover units at scales of } \sim 10 \text { to } \\
50 \mathrm{~cm} \text {, with same morphology as those in the } \\
\text { southeast domain. }\end{array}$ \\
\hline & 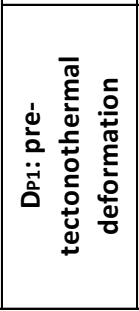 & 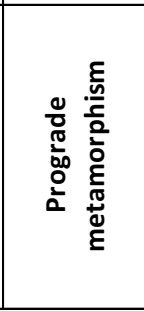 & \begin{tabular}{|l|} 
TT*: structural contact, \\
interpreted as a thrust or \\
reverse-sense brittle fault or \\
ductile shear zone, located at \\
the bases of $\sim 80-600 \mathrm{~m}$-thick \\
couplets of penetratively \\
deformed basement and cover \\
rocks
\end{tabular} & \multicolumn{5}{|c|}{$\begin{array}{l}\text { Occur in all domains. Theoretical prograde deformation prior to the major tectonothermal event (DP2). DP1 structures are likely all overprinted by high strain DP2 structures. } \\
\text { 'TP: The lower boundaries of the basement sheets in the basement-cover couplets (e.g. 'B1'+' 'C1', 'B2'+'C2', etc., Map 1; back pocket), are considered as Paleoproterozoic structural boundaries, likely brittle or ductile thrusts, that } \\
\text { resulted in the repetition and stacking of the basement- cover sheets. The timing and nature of thrusting is uncertain, since they may be either pre-metamorphic brittle thrust faults or syn-metamorphic ductile shear zones, and they } \\
\text { have likely been reactivated under ductile conditions during the main DP2 tectonothermal event. }\end{array}$} \\
\hline
\end{tabular}

Nonconformity between Archean basement and Paleoproterozoic cover rocks.

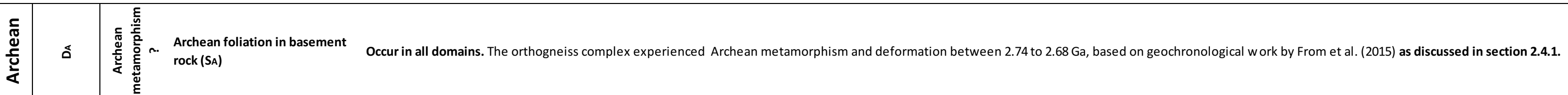


CHAPTER 4 - DISCUSSION OF POSSIBLE MODELS FOR TECTONIC EVOLUTION OF THE STUDY AREA, COMPARISON OF STRUCTURAL STYLE AND INFERRED THERMAL REGIMES WITH REGIONAL STUDIES, AND SIGNIFICANCE OF THE FINDINGS FOR TECTONIC EVOLUTION OF THE NORTHERN HALL PENINSULA 


\subsection{Introduction}

The purpose of this chapter is to explore the significance of the documented structures of the Ptarmigan Fiord study area with respect to published geology of the northern Hall Peninsula. This will be done by integrating the conclusions of this thesis, in particular, structural history from Chapter 3 with information from other studies about the regional structural geology, timing of metamorphism and deformation, and cooling history on the northern Hall Peninsula. The extent of Paleoproterozoic penetrative deformation in the study area will be investigated, and compared with the regional deformation style. The significance of late structures, such as the $\mathrm{T}_{3 \mathrm{c}}$ domain boundary separating the northwest domain form the southeast domain, will be discussed and compared with regional structures. The nature and timing of the basement-cover imbrication, where Archean rocks are stacked onto Paleoproterozoic rocks by means of Paleoproterozoic thrust surfaces $\left(\mathrm{T}_{\mathrm{P}}\right.$, Table 3.1), will be discussed. Implications for structural level in the THO orogen during thrust-repetition of basement-cover couplets will be discussed based on the proposed models for basement-cover imbrication, and previous pressure-temperature-time (P-T-t) studies.

\subsection{Integration of thesis results with structural, metamorphic, geochronology, and thermochronology studies in the region}

The purpose of this section is to integrate the Ptarmigan Fiord structural data and inferred structural history from Chapter 3 with information from regional structural analysis, and studies on the absolute timing of metamorphism and cooling on northern Hall Peninsula derived from the literature (e.g. Skipton et al., (2016) and references 
therein). Integrating these studies may help to better constrain the geological history of the Ptarmigan Fiord area.

\subsubsection{Comparison of structures in the study area and northern Hall Peninsula}

A comparison of structures of the Ptarmigan Fiord area and the regional area is discussed in this section. Regional structural observations were mostly made southeast and southwest of the Ptarmigan Fiord area (Figure B, Map 1; back pocket). However one structural and metamorphic station (S089, Map 2; back pocket) belonging to the regional study by Skipton et al. (2016), is located in the Ptarmigan Fiord area. The structures of the Ptarmigan Fiord area (Chapter 3, this study) and the northern Hall Peninsula (Skipton et al. 2016, and references therein), are presented in separate columns in Table 4.1. The columns are aligned so that generations of structures from both Ptarmigan Fiord and the northern Hall Peninsula that are assumed to have formed during the same tectonothermal regime are listed on the same line (i.e. information about pre-synthermal peak structures in the Ptarmigan Fiord area are aligned next to regional pre-synthermal peak structures). Only Paleoproterozoic structures will be discussed.

Data from this study and those from the northern Hall Peninsula suggest that early structures formed during prograde deformation and were subsequently overprinted during syn- to post-thermal-peak deformation (Table 4.1). In the northern Hall peninsula, peak and near-peak metamorphic minerals occur as inclusion trails in garnet (i.e. $\mathrm{S}_{1}$ ), which have been interpreted by Skipton et al. (2016) to potentially record prograde $\mathrm{D}_{1}$ deformation. Metamorphic $\mathrm{U}-\mathrm{Pb}$ monazite ages for these inclusion trails are presented in Section 4.2.2. Although garnet inclusion trails are not observed in specimens from the 
Ptarmigan Fiord area, it is possible that prograde structures (e.g. early faults and folds inferred as $\mathrm{D}_{\mathrm{P} 1}$; Table 4.1) may have existed before being overprinted and transposed during pre- to synthermal-peak D22 deformation.

In both the local Ptarmigan Fiord and regional Hall Peninsula studies, structures such as intrafolial isoclinal folds and a penetrative foliation and lineation, defined by thermal-peak and anatectic minerals, are interpreted to be the result of a significant presynthermal peak deformation event (i.e. $\mathrm{D}_{\mathrm{P} 2}$ in Ptarmigan Fiord and $\mathrm{D}_{1}$ in Hall Peninsula; Table 4.1). However, the timing of imbrication of basement-cover couplets along discrete structural boundaries $\left(\mathrm{T}_{\mathrm{P}}\right)$ is apparently different in the two study areas. In the Ptarmigan Fiord area, basement-cover imbrication is interpreted as either early brittle deformation (e.g. $D_{P 1}$ ) or an early $D_{\mathrm{P} 2}$ transposition structure, that occurred when the rocks where relatively cool and strong, behaving as rigid sheets (i.e. before anataxis and the thermal metamorphic peak) and prior to or during D $22_{2}$ penetrative overprinting by $\mathrm{S}_{2 \mathrm{a}}$ foliations and $\mathrm{L}_{2 \mathrm{a}}$ lineations. In contrast, Skipton et al. (2016) interpret the basement-cover imbrication $\left(T_{2}\right)$ on western Hall Peninsula to have been caused by thick-skinned reverse faults, and as a syn- to post-thermal-peak structure (Table 4.1). This is based on field observations of $T_{2}$ thrusts juxtaposing higher-grade rocks over lower-grade rocks, resulting in an inverted metamorphic zonation (i.e. field gradient), indicating that $\mathrm{T}_{2}$ thrusting was post-thermal-peak on the scale of individual thrusts. However, these authors also attribute $\mathrm{T}_{2}$ thrusting as a major component of crustal thickening, contributing to peak metamorphic conditions, and therefore $T_{2}$ is interpreted as a synthermal peak structure. This topic will be revisited in Section 4.3, where the nature of basement-cover imbrication in the Ptarmigan Fiord area is discussed. 


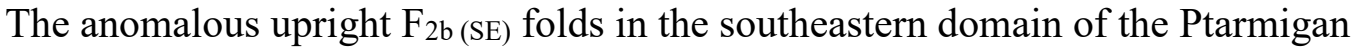
Fiord area and the regional $\mathrm{F}_{2}$ folds in the northern Hall Peninsula are both interpreted to have formed during syn- to post-thermal peak conditions (Table 4.1). However, the inferred $\sim$ NE-SW crustal shortening direction of $F_{2 b}$ (SE) fold in the Ptarmigan Fiord area differs from the E-W shortening direction of $F_{2}$ in the northern Hall Peninsula. Also, axial planar leucosome veins $\left(\mathrm{S}_{2 b}\right)$, and post-thermal peak $\mathrm{F}_{3 \mathrm{~b}}$ folds are present in the Ptarmigan Fiord area, but are not documented in the northern Hall Peninsula. More work is required to assess the fold orientation differences between the two studies. Finally, the $\sim$ NW-SE striking couplets of the southeast domain are anomalous within the Ptarmigan Fiord area (and northern Hall Peninsula). An explanation for their orientation, and the existence of the upright $\mathrm{F}_{2 b}$ folds, may be the presence of variably oriented ramps during thrusting or $\mathrm{D}_{\mathrm{P} 2}$ transposition; discussed in Section 4.3.

\subsubsection{Integrating results of metamorphic and geochronology studies in the northern}

\section{Hall Peninsula with the Ptarmigan Fiord area}

Metamorphic petrology and geochronology studies by Skipton et al. (2016; and references therein) characterize the nature and timing of thermal-peak metamorphism and coincident deformation, as well as the cooling history of northern Hall Peninsula. Integration of these results with the structural data from the Ptarmigan Fiord area (Table 4.1), better constrains the conditions and timing of the structural history of the Ptarmigan Fiord area.

Petrography, mineral chemistry, and equilibrium phase modelling of northern Hall Peninsula rocks (including sample S089A from Ptarmigan Fiord, Map 2; back 
pocket) indicate that metamorphic conditions of the eastern part of Hall Peninsula reached amphibolite-facies temperatures of $\sim 720-740^{\circ} \mathrm{C}$ and pressures of $\sim 6.25-7.25$ kbar, corresponding to mid-crustal depths of 20-25 kilometers based on an assumed crustal density of $2700 \mathrm{~kg} / \mathrm{m}^{-3}$ (Skipton et al., 2016). In situ U-Pb monazite dating of $\mathrm{S}_{1}$ foliation-aligned grains and grains aligned as garnet inclusion trails, indicate that Edirected (i.e. $\mathrm{D}_{1}$, thermal-peak) crustal shortening occurred at ca. 1850-1825 Ma (Skipton et al., 2016). Because regional $\mathrm{T}_{2}$ and $\mathrm{F}_{2}$ structures are interpreted to have contributed to crustal thickening and thus thermal-peak conditions, regional $\mathrm{D}_{2}$ is interpreted to have formed during or after ca. 1850-1825 Ma (Table 4.1). Monazite dated at ca. $1800 \mathrm{Ma}$ are rarely found within garnet, and those that do are located within microfractures close to garnet rims, and those found within the matrix are not oriented with the $\mathrm{S}_{1}$ foliation, indicating that they postdate garnet growth and $\mathrm{S}_{1}$ (Skipton et al., 2016). Skipton et al. (2016) interpret the younger (i.e. ca. $1800 \mathrm{Ma}$ ) monazite growth as likely due to fluidassisted dissolution- reprecipitation that appears to correlate with retrograde muscovite growth and south-directed crustal shortening. Therefore, ca. 1800 Ma monazite ages are interpreted as $\mathrm{D}_{3}$ post-thermal peak deformation age.

Skipton et al. (2016) interpret the thermal-peak metamorphism and east-directed shortening (i.e. $\mathrm{D}_{1}, \mathrm{D}_{2}$ ) at ca. 1850-1825 Ma to have occurred during an accretionary event in the upper Churchill plate of THO, potentially during Andean-margin-style subduction of the Narsajuaq arc (or Sugluk block) beneath the Meta Incognita microcontinent. The younger ca. 1800 Ma event may have been caused by terminal collision of the THO at ca. 1820-1795 Ma, as the lower-plate Superior craton collided with the upper Churchill plate (Skipton et al., 2016). U-Pb metamorphic titanite ages of 
ca. $1742-1730 \mathrm{Ma}$ (Scott, 1999) indicate that temperatures of $>550^{\circ} \mathrm{C}$ (Cherniak, 1993) were maintained for at least ca. $95 \mathrm{Ma}$ after thermal-peak conditions. Muscovite ${ }^{40} \mathrm{Ar}-$ ${ }^{39} \mathrm{Ar}$ ages of ca. $1690-1657$ Ma may indicate that northern Hall Peninsula remained hotter than $\sim 420-450^{\circ} \mathrm{C}$ (Harrison et al., 2009) for at least ca. 140 Ma after thermal-peak conditions (Skipton et al., 2015). K-Ar ages of muscovite (ca. 1610 Ma; Lowdon, 1960), hornblende (ca. $1670 \mathrm{Ma}$; Wanless et al., 1979) and biotite (ca. 1700-1507 Ma; Wanless et al., 1968), although variable, also support a slow cooling history (Skipton et al., 2016).

Correlations in structural style and inferred thermal regimes can be made between the Ptarmigan Fiord study and the regional study conducted by Skipton et al. (2016). Ptarmigan Fiord DP2 structures are deemed equivalent to Hall Peninsula $\mathrm{D}_{1}$ and $\mathrm{D}_{2}$ structures, based on similarities of structures between the two areas (Table 4.1; described below). Similarly, there are $F_{3}$ post-thermal-peak folds in both area. However, there are late- $\mathrm{D}_{\mathrm{P} 3}$ structures in the Ptarmigan Fiord area that do not have any corresponding structures elsewhere in the Hall peninsula (Table 4.1). Based on the inferred correlations of structural style and thermal regime between the two studies, ages derived by Skipton et al. (2016) are assigned to the structures in the Ptarmigan Fiord area (Table 4.1). The results are as following:

- In the Ptarmigan Fiord area, the major tectonothermal event (DP2), is interpreted to correlate with the main $\mathrm{D}_{1}$ and $\mathrm{D}_{2}$ tectonothermal events occurring at the regional scale. This is based on the similarities of structures and metamorphic mineral assemblages, supporting pre-synthermal peak metamorphic mineral growth and syn- to post-thermal peak metamorphic mineral growth in both studies 
(Table 4.1). Based on the correlated structures and inferred metamorphic thermal evolution, the regional $\mathrm{D}_{1}$ and $\mathrm{D}_{2}$ age of ca. 1850-1825 Ma may be inferred for the $\mathrm{D}_{\mathrm{P} 2}$ event in the Ptarmigan Fiord area, and the interpretation that $\mathrm{D}_{1}$ is related to an accretionary collisional event in the upper Churchill plate collage of the THO, may also be inferred for the $\mathrm{D}_{\mathrm{P} 2}$ event in the Ptarmigan Fiord area.

- The $\mathrm{D}_{\mathrm{P} 3}$ and $\mathrm{D}_{\mathrm{P} 4}$ events in the Ptarmigan Fiord area, are interpreted to correlate with the $\mathrm{D}_{3}$ regional event. This is based on similarity in structures that form postthermal peak, in both studies (Table 4.1). Based on the correlated structures and inferred metamorphic evolution, the $\mathrm{D}_{3}$ age of ca. 1800 Ma may be inferred for the $\mathrm{D}_{\mathrm{P} 3}$ and $\mathrm{D}_{\mathrm{P} 4}$ events in the Ptarmigan Fiord area, and the interpretation that $\mathrm{D}_{3}$ is related to the terminal collision of the THO, may also be inferred for the $\mathrm{D}_{\mathrm{P} 3}$ and DP4 events in the Ptarmigan Fiord area.

- A slow cooling history after $\mathrm{D}_{\mathrm{P} 3}$ and $\mathrm{D}_{\mathrm{P} 4}$ (between ca. $1800 \mathrm{Ma}$ and $1610 \mathrm{Ma}$ ), is evidenced from cooling history studies conducted at the regional scale. A slow cooling history may explain the high degree of annealing observed in crystalline basement rocks in the study area.

\subsection{Structural style of basement-cover imbrications and implications for structural level}

As outlined in Chapter 3, at least three end member models can be considered to explain the thrust-repetition $\left(\mathrm{T}_{\mathrm{P}}\right)$ of basement-cover couplets, responsible for juxtaposing 
older Archean rocks over younger Paleoproterozoic rocks in the Ptarmigan Fiord area. These include:

1) imbrication and stacking of basement and cover rocks during syn- to post-thermal peak conditions by discrete 'ductile thrusting' in the mid-crust;

2) imbrication and stacking of basement-cover rocks by thrust or reverse-sense brittle faults in the upper-crust during prograde metamorphism prior to synthermal-peak $\mathrm{D}_{\mathrm{P} 2}$ deformation and penetrative overprinting; or

3) imbrication of basement and cover rocks by penetrative mid-crustal flow and/or sheared out nappes during thermal-peak metamorphic conditions.

In all cases, there may have been reactivation of the original structures and overprinting by ductile shear zones at the basal basement contacts $T_{P}$.

Any tectonic model must explain: imbrication of basement and cover couplets $\left(\mathrm{T}_{\mathrm{P}}\right)$; the penetrative transposition foliation $\left(\mathrm{S}_{2 \mathrm{a}}\right)$ that occurs throughout the repeated basement-cover rocks; concordance of $\mathrm{T}_{\mathrm{P}}$ basal structural contact and inferred depositional contact of individual basement-cover couplets with the penetrative transposition foliation $\left(\mathrm{S}_{2 \mathrm{a}}\right)$ and $5-10-\mathrm{m}$ thick, localized shear zones and mylonite interpreted as higher strained equivalents of $\mathrm{S}_{2 \mathrm{a}}$ that occur at basal basement contacts, upper basement contacts and within basement sheets.

\subsubsection{Basement-cover imbrication by ductile thrusting}

Discrete thrusting on ductile mylonites that carry crystalline sheets, as outlined by Boyer and Elliot (1982) and Butler (1987), has been applied as a model for imbricating crystalline basement and metasedimentary cover rocks in numerous orogens including: 
the Scandinavian Caledonides (Gee 1975a,b), Caledonides of Northwest Scotland (Coward 1980, 1983, 1984; McClay and Coward, 1981; Butler, 1982, 1984, 1986; Coward and Park, 1987), the Caledonides of northern Norway (Boullier and Quenardel, 1981), the northwest Alps (Butler, 1983; Platt,1984), and the Canadian Cordilleras (Duncan, 1984; McDonough and Parrish, 1991; Brown et al., 1992; Gibson et al., 1999). The analogy for this model is drawn from brittle thrusting as exhibited in the Rocky Mountain thrust and fold belt (Williams and Jiang, 2005). Rocky Mountain thrust and fold belt terms such as 'sole thrust', 'roof thrust' and 'duplex' (Butler, 1982) were adopted to describe the structures in some of these high-grade areas (e.g. Brown et al., 1986; Brown and Journeay, 1987; McNicoll and Brown, 1995; Crowley, 1999; Gibson et al., 1999).

In the Ptarmigan Fiord area, the model of ductile thrust-imbrication of basement and cover during $\mathrm{D}_{\mathrm{P} 2}$ syn- to post-thermal peak deformation, prior to modification by younger folds, has been proposed by Steenkamp and St-Onge, 2014; Dyck and St-Onge, 2014; Chadwick et al., 2015; and Skipton et al., 2016. In this model, based on examples in the literature listed above, the variably strained lower basement contacts of repeated imbricates $\left(T_{P}\right)$ represent ductile thrust faults, while the upper basement contacts represent a lower-strain reworked nonconformable contacts (Map 1; back pocket). This model is partially supported from field observations and the strain analysis of basementcover contacts at Ptarmigan Fiord, where lower basement contacts are $5-10$ m-thick shear zones, and more highly strained compared to that of upper contacts. Strain variability at the upper and lower contacts could also be due to contact reactivation during post-imbrication folding $\left(\mathrm{F}_{2 \mathrm{~b}}, \mathrm{~F}_{3 \mathrm{a}}\right.$, etc.). 
Thrust system components such as frontal, side-wall, and lateral ramps (Butler, 1987) might help explain the orientation of couplets of basement-cover sheets and domain boundaries in Ptarmigan Fiord area, as well as variations in unit thickness and shear-sense from domain to domain (Map 1; back pocket). In the northern and northwest domains in the Ptarmigan Fiord area, the orientation of $\sim$ N-S-striking couplets of imbricated basement-cover, with top-to-the-E or SE shear sense (red arrows, Figure G, Map 1; back pocket), could have been controlled by W-dipping frontal ramps, while $\sim \mathrm{E}$ W-striking imbricates with sinistral strike-slip and oblique-slip shear sense (blue arrows, Shear Sense Map; back pocket) may have been controlled by N or S-dipping lateral or side-wall ramps. A lateral ramp beneath the proposed northern domain boundary might explain why cover in the northern domain $\left(\mathrm{C}_{\mathrm{ND}}\right)$ cover in the northern domain is much thicker compared to $\mathrm{C} 0$ in the southeast domain (Map 1; back pocket). If the orientation of potential footwall ramps was oblique to the syn-thrusting shortening direction, a hanging wall syncline could have formed in the same orientation as the $\mathrm{F}_{2 \mathrm{~b}}(\mathrm{SE})$ syncline. In this model, the basement ramp acted as a buttress to localize flow folds. The interpretation of $\mathrm{F}_{2 \mathrm{~b}}$ (SE) as a syncline, localized due to a cold basement ramp beneath, could explain the rarity of the $\sim \mathrm{NW}$ - SE orientation of $\mathrm{F}_{2 b}$ (SE) folds in the study area, and potentially the northern Hall Peninsula, where $\sim \mathrm{N}-\mathrm{S}$ oriented couplets are dominant (Figure B, Map 1; back pocket).

Lateral and frontal ramps have also been used explain complex strain patterns in in the Moine thrust zone of Scotland, such as variable foliation orientations and intensities, refolded folds and foliations, and folds with hinges almost parallel to the main transport direction (Coward and Potts, 1983). These same structural complexities exist in 
the Ptarmigan Fiord area, and may provide support for a potential thrust model with complex ramp geometries.

If structures controlling the map pattern are interpreted in the context of a foreland fold and thrust belt model, then a sole thrust or basal décollement should exist below the study area. Skipton et al. (2016) propose a W-dipping basal décollement under Hall Peninsula, which separates folded and imbricated basement and cover rocks from underlying undeformed basement rocks (Figure C, Map 1; back pocket). This inferred basal décollement and underlying basement may project into the Ptarmigan Fiord area, helping to explain the abundance of basement in the northern and southern domains.

\subsubsection{Basement-cover imbrication by pre-Dp2 brittle thrusting}

A second potential model involves the imbrication of basement and cover by thrusting in a brittle regime, prior to transposition and thermal-peak metamorphism. This model accounts for higher strain mylonite zones at the basement-cover contacts, likely reworked by strain localization due to competency contrasts during $\mathrm{D}_{\mathrm{P} 2}$ transposition. Williams and Jiang (2005) argue that such ductile 'fault zones' are not evidence of thrusting in the conventional sense, but rather indicate reactivation of an earlier surface or fault that has been rotated into approximate (but never complete) parallelism with the shear plane.

Based on evidence of high-grade metamorphism and transposition in the Ptarmigan Fiord area, this hybrid brittle-ductile deformation model could be appropriate to explain the 'thrust-like' basement-cover imbricates. If ancestral ( $\mathrm{D}_{\mathrm{P} 1}$ ?) structures, such as $T_{P}$ brittle thrust faults, are controlling the basement-cover imbrication in the study 
area, then they could account for the complex strain variability and shear-sense patterns within the study area, imbrication of basement and cover couplets, concordance of $\mathrm{T}_{\mathrm{P}}$ basal structural contact and inferred depositional contact of individual basement-cover couplets with the penetrative transposition foliation $\left(\mathrm{S}_{2 \mathrm{a}}\right)$, and $5-10-\mathrm{m}$ thick, localized shear zones and mylonite interpreted as higher strained equivalents of $\mathrm{S}_{2 \mathrm{a}}$ that occur at basal basement contacts, upper basement contacts and within basement sheets.

\subsubsection{Basement-cover imbrication by nappes and mid-crustal flow}

Imbrication of basement and cover in the mid-crust by means of flow folds and nappe development has also been proposed for high-grade high-strain terranes such as the Monashee complex (Williams and Jiang, 2005; Hinchey et al., 2006; Gervais et al., 2010; Spalla et al., 2011), Scottish Caledonides (Coward and Potts, 1985; Strachan and Holdsworth, 1988; Holdsworth et al., 2001; Alsop et al., 2010) and the Grenville Orogen (van Breeman et al., 1986; Wodicka et al., 1996, 2000; Culshaw et al., 2010). During high-strain nappe development in the mid-crust, cover rocks are typically infolded with basement, giving them the appearance of thrust imbricate stacks. However, unlike the thrust model, which repeats right-way-up basement overthrust on younger cover, recumbent nappes produce overturned limbs and vergence reversals if the short limbs are preserved.

Although the aspect of repeated basement sheets and cover may be similar to that of basement involved thrust structures in the internal zones of foreland thrust and fold couplets, there are significant differences between the two structural styles apart from metamorphic grade (Williams and Jiang, 2005). The main difference in structural style is 
that Rocky Mountain thrust and fold belt type thrust sheets are unmetamorphosed or metamorphosed at a low grade, strongly controlled by softer stratigraphic layers, and contain fault bend folds, so that internal primary structures are preserved, whereas primary structures in high-grade nappes are completely transposed, indicating that intense internal deformation occurred. In the Rocky Mountain thrust and fold belt situation, deformation is generally brittle, and is essentially concentrated on the thrust plane. In high-grade nappes, deformation is penetrative and almost always ductile, and there is not necessarily any recognizable variation in the intensity of deformation across nappe boundaries (Williams and Jiang, 2005).

The penetrative nature of deformation within the high-grade rocks of Ptarmigan Fiord area, where a transposition foliation of varying intensity is present throughout imbricated basement and cover rocks, and parallel to the basement-cover contacts, could be evidence for nappe development in the area. The presence of intrafolial mature folds $\left(\mathrm{F}_{2 \mathrm{a}}\right)$ could also be viewed as evidence for nappe development. However, there is no evidence for overturned limbs of nappes, vergence reversals, or changes in tectonostratigraphic polarity across imbricated basement-cover couplets in the Ptarmigan Fiord area, which are basic requirements for a model of basement-cover imbrication by recumbent nappes.

\subsubsection{Favoured model(s) for basement-cover imbrication}

Based on the structural style and history of the study area (Table 3.1) and the regional deformation history of the Hall Peninsula (Table 4.1), the second model (Section 4.3.2) is favoured, where juxtaposition of older basement rock onto younger cover rock, 
is the result of initial brittle thrusting prior to thermal-peak conditions, followed by penetrative high-strain DP2 overprinting deformation, transposition, and development of localized shear zones. A possible modification to this model is the potential occurrence of discrete mylonite zones at the margins of strong basement sheets, similar to those documented in the Malton complex of southern British Colombia (Simony and Carr 2011). The favoured model accounts for the complex strain variability and shear-sense patterns within the study area, if complex ramp geometries were controlling the orientation of thrusting. During $\mathrm{D}_{\mathrm{P} 2}$ deformation, strain most likely localized along preexisting discontinuities within and at the contacts of basement sheets, resulting in the localized shear zones within the repeated basement sheets. This model also accounts for the required prograde crustal thickening responsible for the estimated amphibolite to granulite facies conditions recoded on the Hall Peninsula, by structurally thickening of the crust by thrust-stacking of basement-cover couplets. Also, by suggesting that imbrication was the result of brittle thrusting processes, the contrasting contact orientations (i.e. anomalous $\sim$ NW-SE-striking couplets of the southeast domain vs. NE-SW-striking couplets of the northwest domain), and unit thicknesses between the southeast and northwest domains, can be potentially explained using different ramp geometries (frontal, side-wall, and lateral ramps). In this model, the anomalous upright $F_{2 b}$ (SE) syncline in the southeast domain could represent a hanging wall syncline that formed as a result of a basement ramp geometry that acted as a buttress to localize flow folds.

\subsection{Extent of Paleoproterozoic deformation in basement?}


Confidence about the extent of overprinting penetrative Paleoproterozoic deformation in Archean basement rocks is limited to the area focused on couplets of thrust-repeated basement-cover couplets in the southeast and northwest domains of the Ptarmigan Fiord area (Figure F, Map 1; back pocket), where a penetrative transposition foliation of varying intensity occurs throughout all units. A moderately developed transposition foliation is identified in 'B0' basement rocks from lowest structural level in the southeast domain (station C036, Map 2; back pocket), and may indicate that Paleoproterozoic deformation affected all basement rocks of the southeast domain. However, the extent of $S_{2 a}$ is uncertain in all or part of the basement in the northern and southern domains, and if not present, could represent footwall rocks at the base of the orogen beneath a potential basal décollement. Detailed structural mapping in the extensive basement rocks of the Ptarmigan Fiord area, might help to answer the question about its involvement in Paleoproterozoic deformation. Metamorphic studies coupled with U-Pb monazite dating of basement fabrics may also shed some light on the extent of basement involvement during Paleoproterozoic deformation. Thermochronological studies (e.g. ${ }^{40} \mathrm{Ar}-{ }^{39} \mathrm{Ar}$ dating) of basement rocks might demonstrate whether or not the basement that was involved in $\mathrm{D}_{\mathrm{P} 2}$ (containing a Paleoproterozoic cooling history) versus footwall basement at the base of the orogen (which remained cold and undeformed during Paleoproterozoic $\mathrm{D}_{\mathrm{P} 2}$ ).

\subsection{Significance of the $T_{3 c}$ domain boundary between the northwest and southeast domains}


The $\mathrm{T}_{3 \mathrm{c}}$ domain boundary is a moderately NW-dipping ductile shear zone that juxtaposes a $\sim$ NW dipping panel of basement-cover couplets onto $\sim$ NW - SE striking couplets of the southeast domain. In the favoured model of progressive brittle to ductile deformation, where pre-DP2 brittle thrust faults are responsible for thrust-imbricating basement and cover couplets, the $\sim \mathrm{NE}-\mathrm{SW}$ trending $\mathrm{T}_{3 \mathrm{c}}$ domain boundary could represent a late ductile thrust fault that crosscuts the $\mathrm{F}_{2 \mathrm{~b}}(\mathrm{SE})$ syncline. This initial out-ofsequence-thrust, or potentially reactivated ductile shear zone, was responsible for juxtaposing the rocks of the northwest domain onto the southeast domain (Map 1; back pocket). Alternatively, the $\mathrm{T}_{3 \mathrm{c}}$ fault may have formed during a late, cooler (?) deformation regime that favoured brittle-ductile reverse-faulting over ductile folding.

\subsection{Significance of the study for the tectonic evolution of the northern Hall Peninsula and the Trans Hudson Orogen}

Tectonic repetition of basement and cover rocks played an important role in structurally thickening the crust on Hall Peninsula, which contributed to high-grade metamorphism, anatexis, and ductile deformation recorded in the rocks. The most significant finding from this study is that unit contacts on Hall Peninsula may preserve a more complex history than understood previously, potentially rooted in different tectonic processes at varying crustal levels. Not all supracrustal contacts need be primary structures (i.e. there may be interleaved tectonic contacts between potential primary contacts), and the nature of basement-cover contacts is largely obscured by penetrative transposition deformation (DP2; table 3.1) and shear zones that localized on basement contacts. Data from Ptarmigan Fiord suggest that basement-cover contacts are variably 
strained, transposed into parallelism with the transposition foliation, and contain complex strain gradients that vary within individual imbricates and between imbricates.

Contrasting rheological properties between basement and cover rocks, along with potential pre-transposition deformation surfaces, likely influenced strain partitioning and created varying strain gradients in the area.

Based on the proposed models for basement-cover imbrication (section 4.3), the rocks on Hall Peninsula may have experienced a complex period of early brittle or localized ductile deformation responsible for basement-cover imbrication, peak metamorphism, in-situ melting, and high-strain ductile deformation and transposition between ca. 1850 and 1825 Ma. Early foreland fold and thrust belt processes may have imbricated basement and cover rocks along discrete thick-skinned thrust faults, which may have been later reactivated as ductile shear zones in the mid-crust. There is also some evidence supporting the presence of side-wall or lateral ramps during early brittle deformation or late $\mathrm{D}_{\mathrm{P} 2}$. This study has also shed light on previously unrecognized fold complexity in the region, especially within fold hinges of $\sim$ E-W striking upright folds.

The localized strain gradients are likely caused by local rock properties (i.e. rheological contrasts, pre-existing weaknesses, presence of fluids, etc.). Variably strained basement-cover contacts are aligned parallel to the $\mathrm{S}_{2 \mathrm{a}}$ transposition foliation, and are interpreted to be at least the same age or younger than $\mathrm{S}_{2 \text { a. }}$. There is also the possibility that lower structural boundaries between imbricated basement-cover couplets $\left(\mathrm{T}_{\mathrm{P}}\right)$ may be pre- $\mathrm{D}_{\mathrm{P} 2}$ age and were later reactivated as ductile shear zones during $\mathrm{D}_{\mathrm{P} 2}$. $\mathrm{T}_{\mathrm{P}}$ basal thrusts were also likely reworked by post-DP2 deformation, adding further complexity to the strain, kinematic, and annealing history of these contacts. 
Table 4.1. Comparison of structural style and inferred thermal regimes of the Ptarmigan Fiord area and the Skipton et al. (2016) regional study. The columns are aligned so that generations of structures from both Ptarmigan Fiord and the northern Hall Peninsula that are inferred to have formed during the same tectonothermal regime are listed on the same line (i.e. information about pre-synthermal peak structures in the Ptarmigan Fiord area are aligned next to regional pre-synthermal peak structures). Archean structures are omitted and only the Paleoproterozoic structures are compared. 
Ptarmigan Fiord Area Structural Observations

\begin{tabular}{|c|c|c|}
\hline \multirow[b]{2}{*}{ Stage } & \\
\hline & $\begin{array}{l}\text { Thermal } \\
\text { Regime }\end{array}$ & Structure \\
\hline 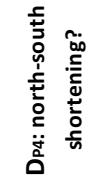 & \multirow[b]{2}{*}{ 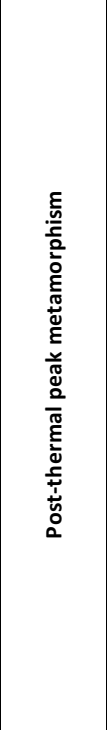 } & $\begin{array}{l}\text { F4 ?: gentle bend in the NE-SW } \\
\text { to } \mathrm{N}-\mathrm{S} \text { trending basement- } \\
\text { cover contacts in the } \\
\text { northwest domain and } \\
\text { potentially } \mathrm{T} 3 \mathrm{c} \text { domain } \\
\text { boundary shear zone }\end{array}$ \\
\hline 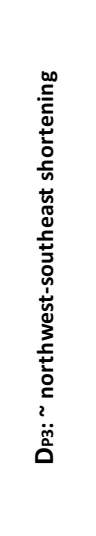 & & $\begin{array}{l}\text { T3c: ductile reverse fault that } \\
\text { juxtaposed the northwest and } \\
\text { southeast domains } \\
\text { Fзs: map scale steeply } \\
\text { inclined folds with SW- } \\
\text { striking, NW-dipping axial } \\
\text { surfaces that plunge steeply } \\
\text { to the W, believed to be } \\
\text { gentle folds based on the map } \\
\text { scale folding of basement- } \\
\text { cover imbricates } \\
\text { S3a: crenulation cleavage } \\
\text { F3a: upright - steeply inclined, } \\
\text { ESE-dipping folds that are sub- } \\
\text { horizontally plunging to the } \\
\text { SSW and NNE. Are typically } \\
\text { open - gentle folds }\end{array}$ \\
\hline \multirow{2}{*}{ 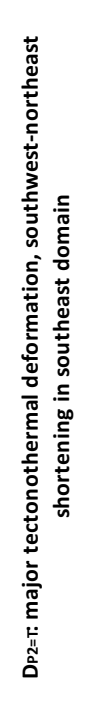 } & 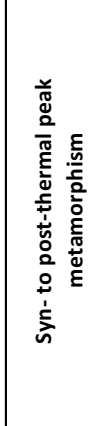 & $\begin{array}{l}\text { T2c: NW-SE striking domain } \\
\text { boundary faults } \\
\text { S } 2 b \text { (SE): weak cleavage }_{\text {development and alignment }} \\
\text { of leucosome veinlets axial } \\
\text { planar to F2b (SE) } \\
\text { F2b (SE): cylindrical, } \\
\text { asymmetric, close to open, } \\
\text { upright to steeply inclined, } \\
\text { generally SE-dipping folds } \\
\text { that plunge gently-to- } \\
\text { moderately to the SE and NW. } \\
\text { Forms synclinal keel map } \\
\text { pattern in eastern domain }\end{array}$ \\
\hline & 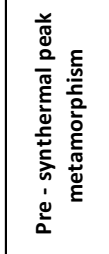 & $\begin{array}{l}\text { L2a=T: stretching and mineral } \\
\text { lineation }\end{array}$ \\
\hline 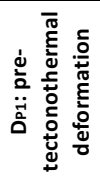 & 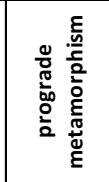 & $\begin{array}{l}\text { TP*: thrust-repeted } 80-600 \\
\text { m-thick couplets of } \\
\text { pentratively deformed } \\
\text { basement and cover rocks, } \\
\text { separated at their bases by } \\
\text { thrust or reverse-sense faults }\end{array}$ \\
\hline
\end{tabular}

Hall Peninsula Area Structural Observations and Geochronology, after Skipton et

$$
\text { al. (2016) }
$$

\begin{tabular}{|c|c|c|c|c|}
\hline Stage & $\begin{array}{l}\text { Thermal } \\
\text { Regime }\end{array}$ & Structure & Regional Deformation Event & Absolute Ages \\
\hline 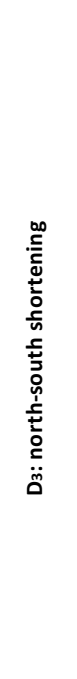 & 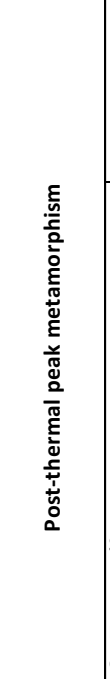 & $\begin{array}{l}\text { S3: crenulation cleavage axi, } \\
\text { F3: thick-skinned folds; } \\
\text { crenulations }\end{array}$ & $\begin{array}{l}\text { Ca. } 1800 \text { Ma monazite dates support } \\
\text { timing of region post thermal-peak } \\
\text { tectonothermal episode, with south- } \\
\text { directed crustal shortening }\left(\mathrm{D}_{3}\right) \text {. This } \\
\text { event was synchronous with the } \\
\text { terminal collision of the } \mathrm{THO} \text { at ca. } \\
1820-1795 \mathrm{Ma} \text {, when the lower plate } \\
\text { Superior craton collided with the } \\
\text { upper Churchill plate }\end{array}$ & \begin{tabular}{|l|} 
In situ U- \\
Pb monazite \\
geochronology \\
age of ca. $1800 \mathrm{Ma}$
\end{tabular} \\
\hline 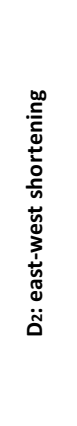 & 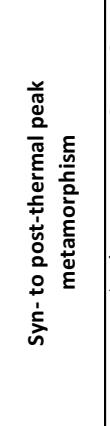 & $\begin{array}{l}\text { F2: thick-skinned folds, } \\
\text { east-verging } \\
\text { L2: mineral stretching and } \\
\text { elongate growth }\end{array}$ & $\begin{array}{l}\text { Syn- to post-thermal-peak thick- } \\
\text { skinned folds and thrusts }\left(\mathbf{D}_{2}\right) \text {, } \\
\text { played an important role in crustal } \\
\text { thickening. Metamorphism and east- } \\
\text { directed shortening }\left(\mathbf{D}_{1}, \mathbf{D}_{2}\right) \text { from c. } \\
1850 \text { to } 1825 \text { Ma represent an } \\
\text { accretionary or collisional event in } \\
\text { the upper Churchill plate collage of } \\
\text { the THO, and potentially Andean } \\
\text { margin style subduction of the } \\
\text { Narsajuaq arc (or Sugluk block?) } \\
\text { beneath the Meta Incognita } \\
\text { Microcontinent }\end{array}$ & \begin{tabular}{|l|} 
\\
\\
In situ U- \\
Ph \\
\end{tabular} \\
\hline 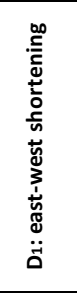 & 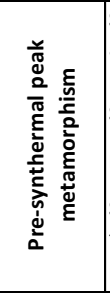 & $\begin{array}{l}\text { S1b: metamorphic foliation } \\
\text { axial planar to } F_{1 a} \\
\text { F1b: isoclinal-open folds of } \\
\text { S1a } \\
\text { L1a,b: mineral lineation } \\
\text { S1a: 'metamorphic } \\
\text { foliation' axial planar to } F_{1 a} \\
\text { F1a: isoclinal folds } \\
\end{array}$ & $\begin{array}{l}\text { The dominant regional deformation } \\
\text { event in the internal zone of the NE } \\
\text { segment of the THO was east- } \\
\left.\text { directed crustal shortening ( } \mathbf{D}_{1}\right) \text {, } \\
\text { concurrent with the thermal-peak } \\
\text { metamorphism, which reached mid- } \\
\text { amphibolite-facies conditions of } \\
720-740^{\circ} \mathrm{C} \text { and } 625-725 \mathrm{kbar} \text { in the } \\
\text { eastern peninsula }\end{array}$ & $\begin{array}{l}\text { metamorphic age } \\
\text { of ca. } 1850 \text { - } 1825 \\
\text { Ma }\end{array}$ \\
\hline $\begin{array}{l}5 \\
0 \\
\frac{0}{0} \\
\frac{\pi}{40} \\
\frac{0}{2} \\
\frac{0}{2}\end{array}$ & 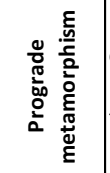 & \multicolumn{2}{|c|}{$\begin{array}{l}\text { Garnet inclusion trails contain peak or near-peak metamorphic } \\
\text { minerals and are interpreted as S1. Monazite within inclusion } \\
\text { trails are dated at ca. } 1850-1825 \mathrm{Ma} \text {. }\end{array}$} & \\
\hline
\end{tabular}

*TP: The lower boundaries of the basement sheets in the basement-cover couplets (e.g. 'B1'+ 'C1', 'B2'+'C2', etc., Map 1; back pocket), are considered as Paleoproterozoic structural boundaries, likely brittle or ductile thrusts, that resulted in the repetition and stacking of the basement- cover sheets. The timing and nature of the thrusts are uncertain, since they may be either pre-metamorphic brittle thrust faults or syn-metamorphic ductile shear zones, and they have likely been reactivated under ductile conditions during the main DP2 $=\mathrm{T}$ tectonothermal event. 


\section{CHAPTER 5 - SUMMARY OF CONCLUSIONS AND FUTURE WORK}




\subsection{Summary of Conclusions}

The purpose of this chapter is to characterize the polydeformed and penetratively deformed, amphibolite-facies rocks, structures and Paleoproterozoic structural history of the Ptarmigan Fiord area, and integration with documented geology and timing constraints from the Hall Peninsula region.

i. The geology of the Ptarmigan Fiord area (Map 1; back pocket), is dominated by an Archean basement complex. They are interleaved with six $80-200 \mathrm{~m}$ thick couplets of Paleoproterozoic metasedimentary and metavolcanic cover rocks and were intruded by Paleoproterozoic syenogranite plutons.

ii. The Archean orthogneiss basement complex consists of variably deformed granodiorite (Unit 1a), monzogranite (Unit 1b), tonalite (Unit 1c), and quartz diorite to gabbro (Unit 1d), as described in Section 2.2.1.

iii. The Paleoproterozoic cover rocks are composed of quartzite (Unit 2), psammitic to pelitic schist (Unit 3), amphibolite (Unit 4), and calc-silicate (Unit 5, Section 2.2.2).

iv. The Paleoproterozoic weakly-foliated syenogranite pluton (Unit 6) crosscuts basement units in the western part of the study area, and is dated at $1861 \pm 2 \mathrm{Ma}$ by N. Rayner (unpublished U-Pb zircon data, 12 December 2016, Section 2.2.3).

v. Some map units of Archean basement in the Ptarmigan Fiord area are similar to and likely correlate with metaigneous map units documented in the SW corner of 
NTS sheet 026A on Hall Peninsula (Figure A, Map 1; back pocket) by From et al. (2015; and references therein). Based on the similarities and correlation of units in the two areas, and geochronology studies by From et al. (2015) and Rayner (2015), the basement rocks record a complex, protracted (ca. 3209 to ca. 2682 Ma) emplacement, metamorphic and deformation history (Section 2.3.1).

vi. The basement is nonconformably overlain by Paleoproterozoic metasedimentary rocks which are interpreted to have been deposited in proximal shallow-marine to more distal continental-shelf and slope-rise depositional settings (section 2.3.2). These depositional environments are inferred from the mapped tectonostratigraphy in the study area (Figure 2.1), which broadly correlates with the regional stratigraphy of the Lake Harbour Group (see Chapter 2 of this thesis; Scott, 1997; St-Onge et al., 2006; Machado et al., 2013a and b; Steenkamp and St-Onge; 2014).

vii. Map-scale repetition and stacking of right-way-up couplets of Archean basementPaleoproterozoic cover couplets (i.e. 'B1' + 'C1', 'B2' + 'C2', etc., Map 1; back pocket) occur in the northwest and southeast parts of the study area (Figure 2.2ab). Where a basement-cover couplet overlies a structurally deeper couplet, there is an 'older-over-younger' relationship. This 'older-over-younger' relationship and repetition of the basement-cover couplets is typical of that in thrust couplets. The basal contacts of basement in basement-cover couplets, are interpreted as brittle or discrete ductile thrust faults $\left(\mathrm{T}_{\mathrm{P}}\right.$; Table 3.1); while the upper contacts are interpreted as non-conformable or reworked non-conformable contacts. The age and nature of structural contacts at the bases of basement-cover couplets $\left(\mathrm{T}_{\mathrm{P}}\right)$ is 
uncertain due to strong post-imbrication penetrative polydeformation and structural overprinting (Section 2.5.1).

viii. Repetition of basement-cover couplets was likely the result of pre-thermal peak brittle thrusting, when rocks were cool and strong enough to be translated as imbricated sheets along discrete brittle faults or ductile shear zones, localized at the bases of the basement-cover couplets. This model assumes that the basement remained strong during thrusting, and that displacement occurred along discrete faults, shear zones or mylonite at the base of individual couplet (Chapter 4). Prethermal peak deformation was followed by penetrative high-strain $\mathrm{D}_{\mathrm{P} 2}$ deformation, transposition, and development of 5-10 m localized shear zones.

ix. All rocks in the study are penetratively deformed, transposed and metamorphosed at amphibolite-facies conditions during a major tectonothermal event termed $\mathrm{D}_{\mathrm{P} 2}$ (Table 3.1). Mature structural elements related to $\mathrm{D}_{\mathrm{P} 2}$ include a transposition foliation $\left(\mathrm{S}_{2 \mathrm{a}}\right)$ with local 5-10 $\mathrm{m}$ thick shear zones of annealed mylonite, stretching lineation $\left(\mathrm{L}_{2 \mathrm{a}}\right)$, and intrafolial or mature folds $\left(\mathrm{F}_{2 \mathrm{a}}\right)$ as summarized in Table 3.1 (Section 3.5.2).

x. Mature $\mathrm{D}_{\mathrm{P} 2}$ structures and basement-cover contacts were folded by at least two generations of folds (Section 3.5), including:

a. Immature map- to outcrop-scale $F_{2 b}$ folds, which are close to open, upright to steeply inclined in the southeast domain $\left(\mathrm{F}_{2 \mathrm{~b}}(\mathrm{SE})\right)$, and gently inclined, open folds with W-dipping fold axes that plunge gently to the $\mathrm{W}$, in the northwest domain. Map scale parasitic $\mathrm{F}_{2 b}$ (SE) folds are common in the southeast domain. Immature $\mathrm{F}_{2 \mathrm{~b}}$ folds are interpreted to be late- $\mathrm{D}_{\mathrm{P} 2}$ based 
on associated axial planar cm-thick leucosome veins $\left(\mathrm{S}_{2 \mathrm{~b}}(\mathrm{SE})\right)$, interpreted to be anatexis related to waning metamorphism (assuming anatexis was solely temperature dependent, and no fluid-assisted melting took place); and

b. DP3 generation folds that include map- to outcrop-scale upright to steeply inclined, shallowly plunging, open to gentle $\mathrm{F}_{3 \mathrm{a}}$ folds, responsible for causing dip reversals of the basement-cover contacts in hinge of the mapscale syncline, and map scale, steeply inclined, steeply plunging, gentle $F_{3 b}$ folds that bent the $F_{2 b}($ SE) axial surface.

xi. The geological map of the Ptarmigan Fiord area is divided into four structural domains, termed the southeast, northwest, northern, and southern domains (Figure F and H, Map 1; back pocket), for the purpose of structural analyses of DP2 and $\mathrm{D}_{\mathrm{P} 3}$ generation folds. In order to sort out the effects of superposed folds, each domain was further divided into subdomains to isolate segments of folds with generally consistent orientations, and the orientation and geometry of folds within each subdomain was assessed through stereonet analysis (Section 3.2).

xii. The southeast domain consists of six 80-200 m-thick sheets of repeated basement and cover occurring in the refolded keel of an upright, close to open, shallowly plunging $F_{2 b}$ (SE) syncline (Table 3.1). The northwest domain, is characterized by a moderately northwest-dipping panel of basement rocks and three couplets of basement- cover couplets (Figure H, Map 1; back pocket). The $\mathrm{T}_{3 c}$ domain boundary between the northwest and southeast domains (Table 3.1), is a late, moderately NW-dipping, SE-directed ductile shear zone. $T_{3 c}$ is significant 
because it truncates the $\sim \mathrm{NW}$-SE striking couplets of basement cover and the $\mathrm{F}_{2 \mathrm{~b}}$ (SE) syncline in the southeast domain, and juxtaposes the NW-dipping panel of basement-cover rocks in the northwest domain against the southeast domain (Section 3.6).

xiii. The $\sim \mathrm{NE}-\mathrm{SW}$ trending $\mathrm{T}_{3 \mathrm{c}}$ domain boundary could represent an out-ofsequence ductile shear zone, or perhaps late brittle fault, with reverse-sense (Section 4.5).

xiv. The northern and southern domains are predominantly basement terranes with minor couplets of cover rocks, and the nature of these domain boundaries is uncertain. The northern and southern domains contain mature DP2 structures and $F_{3 a}$ folds, but no $F_{2 b}$-style folds have been identified in either domain (Sections 3.5.3.1.1 and 3.5.3.1.2).

xv. Localized 5-10 m-thick shear zones and mylonite are manifested at the lower and upper basement contacts, as well as within basement sheets, and could represent ductile reworking of $T_{P}$ and upper non-conformable contacts, as well as preexiting heterogeneities within the sheets, during $\mathrm{D}_{\mathrm{P} 2}$, or post-D $\mathrm{P}_{\mathrm{P} 2}$ deformation (Sections 3.8.1).

xvi. Within this polydeformed study area, basement ramps may have controlled the orientation and thickness of units during early thrusting, and the rare map-scale $\mathrm{F}_{2 \mathrm{~b}}$ (SE) syncline of the southeast domain, may be the product of reactivation along such basement ramps (Chapter 4).

xvii. The four generations of deformation in the Ptarmigan Fiord area ( $\mathrm{D}_{\mathrm{P} 1-\mathrm{D}_{\mathrm{P}} \text {, Table }}$ 3.1) are correlated with regional deformation events (Section 4.2) documented by 
Skipton et al. (2016) using similarities in structural style and inferred thermal regimes. In the Ptarmigan Fiord area and the regional study there is evidence of early prograde deformation ( $\mathrm{D}_{\mathrm{P} 1}$, Table 3.1$)$ responsible for crustal thickening that contributed to amphibolite to granulite facies metamorphism on Hall Peninsula. In the Ptarmigan Fiord area, $\mathrm{D}_{\mathrm{P} 1}$ structures were likely overprinted by $\mathrm{D}_{\mathrm{P} 2}$ structures, and these two generations of deformation are correlated with $\mathrm{D}_{1}$ and $\mathrm{D}_{2}$ regional structures, dated at 1850-1825 Ma. $\mathrm{D}_{\mathrm{P} 3}$ and $\mathrm{D}_{\mathrm{P} 4}$ structures correlate with regional $\mathrm{D}_{3}$ structures, which are dated at $1800 \mathrm{Ma}$ (Skipton et al., 2016; Chapter 4).

\subsection{Future work}

- The nature of geometry of Archean structures, and the extent of Paleoproterozoic penetrative overprinting deformation within the basement is a major outstanding question. One way to address the questions would be to conduct detailed mapping along a transect starting from the structurally lowest basement-cover contact of the southeast domain, with known $\mathrm{D}_{\mathrm{P} 2}$ overprinting structures, and move into unmapped basement of the southern domains to see if $\mathrm{D}_{\mathrm{P} 2}$ structures extend into it. Also, by establishing a 'baseline' structural style and orientation of $\mathrm{D}_{\mathrm{P} 2}$ structures in the southeast domain, possible differences in structural style may be identified in southern domain basement, which may represent Archean structures.

- In addition to a structural study to help establish the extent of D $\mathrm{P}_{2}$ deformation, high temperature geochronological studies, to date metamorphism and deformation (e.g. U-Pb monazite), and thermochronological studies (e.g. ${ }^{40} \mathrm{Ar}-$ 
${ }^{39}$ Ar dating) of basement rock would perhaps demonstrate whether or not the basement that was involved in D 2 (containing a Paleoproterozoic thermal history) versus footwall basement at the base of the orogen (which remained cold and undeformed during Paleoproterozoic DP2).

- Another outstanding question is the nature, potential kinematics and timing of $T_{P}$ faults. A more encompassing structural study across these structures is required in order to better understand them.

- The difference in age between $\mathrm{S}_{2 a}$ parallel and folded leucosome veins, versus $\mathrm{S}_{2 b}$ (SE) axial planar-oriented leucosome veins still remains unknown. Dating leucosome veins in the study area using $\mathrm{U}-\mathrm{Pb}$ zircon geochronology may establish the age and possibly the length of DP2, and combined with a petrological study to put pressure and temperature on it. Dating $\mathrm{S}_{2 \mathrm{~b}}$ (SE) parallel leucosome veins would also determine the age of $\mathrm{F}_{2 \mathrm{~b}(\mathrm{SE})}$ folds. 


\section{REFERENCES}

Allibon, J., Ovtcharova, M., Bussy, F., Cosca, M., Schaltegger, U., Bussien, D. and Lewin, É. 2011: Lifetime of an ocean island volcano feeder zone: constraints from $\mathrm{U}-\mathrm{Pb}$ dating on coexisting zircon and baddeleyite, and ${ }^{40} \mathrm{Ar} /{ }^{39} \mathrm{Ar}$ age determinations, Fuerteventura, Canary Islands; Canadian Journal of Earth Sciences, v. 48, p. 567-592.

Allmendinger, R. W., Cardozo, N., and Fisher, D. 2012: Structural geology algorithms: Computers \& Geosciences, v. 51, p. 193 - 205, doi:10.1016/j.cageo.2012.07.021.

Alsop, G.I., Cheer, D.A., Strachan, R.A., Krabbendam, M., Kinny, P.D., Holdsworth, R.E., Leslie, A.G., 2010: Progressive fold and fabric evolution associated with regional strain gradients: a case study from across a Scandian ductile thrust Nappe, Scottish Caledonides. In: Law, R.D., Butler, R.W.H., Holdsworth, R.E., Krabbendam, M., Strachan, R.A. (Eds.), Continental Tectonics and Mountain Building: the Legacy of Peach and Horne, Geological Society, London, Special Publications, vol. 335, pp. $253 \mathrm{e} 272$

Ansdell, K., Hunchak, A. and Pell, J. 2012: Precambrian basement rocks in the vicinity of the Chidliak kimberlites: initial mapping on the Hall Peninsula, Baffin Island; Geological Association of Canada-Mineralogical Association of Canada, Joint Annual Meeting, St. John's, Newfoundland, program with Abstracts, v. 35, p. 5-6.

Ansdell, K., Hunchak, A. and Pell, J. 2015: Geology, geochemistry and geochronology of basement rocks around the Discovery camp, Chidliak diamond project, northern Hall Peninsula, southern Baffin Island, Nunavut; in Summary of Activities 2014, CanadaNunavut Geoscience Office, p. 45-56.

be published in early 2012).

Beaumont, C., Nguyen, M.H., Jamieson, R.A. \& Ellis, S. 2006: Crustal flow 925 modes in large hot orogens. In: Law, R.D., Searle, M.P. \& Godin, L. (eds) Channel flow, Ductile 
Extrusion and Exhumation in Continental Collision Zones. Geological Society, London, Special Publications 268, 91-145.

Berthe, D., Choukroune, P., and Jegouzo, P. 1979: Orthogneiss, mylonite and non-coaxial deformation of granites: The example of South Armorican shear zone; J. Struc. Geol., v1, p31-32.

Bigio, A. and Lentz, D. 2015: Preliminary lithogeochemistry and geochronology of pegmatites of the Hall Peninsula, Baffin Island, Nunavut: implications for REE mineralization potential; in Summary of Activities 2015, Canada-Nunavut Geoscience Office, p. 1120.

Bigio, A., Budkewitsch, P. and Lentz, D. 2015: Location and characterization of pegmatites in the southern Baffin Island region, Nunavut: field and satellite observations; in Summary of Activities 2014, Canada-Nunavut Geoscience Office, p. 1-10.

Blackadar, R.G. 1967: Geological reconnaissance, southern Baffin Island, District of Franklin; Geological Survey of Canada, Paper 66-47, 32 p.

Bouma, A. H., 1962: Sedimentology of Some Flysch Deposits: Amsterdam (Elsevier).

Braden, Z.M. 2013: Paleoproterozoic pressure-temperature-deformation path in the Newton Fiord region, eastern Baffin Island, Nunavut; B.Sc. thesis, Dalhousie University, 95 p.

Brown, R.L., 1980: Frenchman Cap Dome, Shuswap Complex, British Columbia: a Progress Report. In: Current Research, Part A. Geological Survey of Canada, Ottawa, pp. 47e51.

Butler, R.W.H. 1982: A structural analysis of the Moine Thrust Zone between Loch Eriboll and Foinaven, NW Scotland. J. Struct. Geol. 4, 19-29.

Butler, R.W.H. 1984: Structural evolution of the Moine thrust belt between Loch More and Glendhu, Sutherland. Scott. J. Geol. 20, 161-179.

Butler, R.W.H. 1986: Structural evolution in the Moine of NW Scotland: a Caledonian linked thrust system? Geol. Mag. 123, 1-11.

Butler, R.W.H. 1987: Thrust sequences. J. Geol. Soc. London 144, 619-634. 
Butler, R.W.H. 1982: The terminology of structures in thrust couplets. J. Struct. Geol. 4, 239245.

Cardozo, N., and Allmendinger, R.W. 2013: Spherical projections with OSX Stereonet:

Carr, S.D., 1995: The southern Omineca belt, British Columbia: new perspectives from the Lithoprobe Geoscience program. Canadian Journal of Earth Sciences 32, 1720e1739.

Chadwick, T.C., St-Onge, M.R., Weller, O.M., Carr, S.D. and Dyck, B.J. 2015: Ptarmigan Fiord basement-cover thrust imbricates, Baffin Island, Nunavut; in Summary of Activities 2015, Canada-Nunavut Geoscience Office, p. 61-72.

Corrigan, D., Pehrsson, S., Wodicka, N., de Kemp, E. 2009: The Paleoproterozoic Trans-Hudson Orogen: a prototype of modern accretionary processes. In: Murphy, J.B., Keppie, J.D., Hynes, A.J. (Eds.), Ancient Orogens and Modern Analogues: Geological Society, London, Special Publications, vol. 327, pp. 457-479.

Corrigan, D., 2012: Paleoproterozoic crustal evolution and tectonic processes: Insights from the LITHOPROBE program in the Trans-Hudson orogeny, Canada. Chapter 4 In Tectonic Styles in Canada: The LITHOPROBE Perspective. Edited by J.A. Percival, F.A. Cook, and R.M. Clowes. Geological Association of Canada, Special Paper 49, pp. 237-284.

Coward, M. P. 1983: The thrust and shear zones of the Moine Thrust Zone of NW Scotland. Journal of the Geological Society of London 140, 795-811.

Coward, M. P. and Potts, G. J. 1983: Complex strain patterns at the frontal and lateral tips to shear zones and thrust zones. Journal of Structural Geology 5, 383-399.

Coward, M. P. and Potts, G. J. 1985: Fold nappes: examples from the Moine Thrust Zone. In: The Caledonide Orogen - Scandinavia and related areas (edited by Gee, D. G. and Sturt, B. A.), 1147-1158.

Coward, M.P. \& Park, R.G. 1987: The role of mid-crustal shear zones in the Early Proterozoic evolution of the Lewisian. In: Park R.G. \& Tarney J. (eds) The Lewisian. Spec.Publ. geol. Soc. London, 27, 127-138.

Coward, M.P. 1976: Strain within ductile shear zones. Tectonophysics, 34, 181 - 197. 
Coward, M.P. 1983: Thrust tectonics, thin skinned or thick skinned and the continuation of thrusts to deep in the crust. J. Struct. Geol. 5, 113 - 123

Culshaw, N., Gerbi, C., and Marsh, J. 2010: Softening the Lower Crust: Modes of Syn-transport Transposition around and Adjacent to a Deep Crustal Granulite Nappe, Parry Sound Domain, Grenville Province, Ontario, Canada. Tectonics 29.5.

Davis, J.C. 2002: Statistics and data analysis in geology: Hoboken, NJ, John Wiley 638 p.

Dyck, B.J. and St-Onge, M.R. 2014: Dehydration melting reactions, leucogranite emplacement and the Paleoproterozoic structural evolution of Hall Peninsula, Baffin Island, Nunavut; in Summary of Activities 2013, Canada-Nunavut Geoscience Office, p. 73-84.

Eaton, D.W., and Darbyshire, F. 2010: Lithospheric architecture and tectonic evolution of the Hudson Bay region: Tectonophysics, 480, 1-22.

Fisher, N. I., Lewis, T. L., and Embleton, B. J. 1987: Statistical analysis of spherical data: Cambridge, Cambridge University Press, 329 p.

From, R.E., Camacho, A.L. and St-Onge, M.R. 2013: Preliminary observations on the nature and origin of the eastern orthogneiss complex of southern Hall Peninsula, Baffin Island, Nunavut; in Summary of Activities 2012, Canada- Nunavut Geoscience Office, p. 4354.

From, R.E., St-Onge, M.R. and Camacho, A.L. 2014: Preliminary characterization of the Archean orthogneiss complex of Hall Peninsula, Baffin Island, Nunavut: insights from the 'snow bowl' study area; in Summary of Activities 2013, Canada- Nunavut Geoscience Office, p. 53-62.

From, R.E., Rayner, N.M. and Camacho, A. 2015: Archean magmatism and metamorphism of eastern Hall Peninsula, southern Baffin Island, Nunavut; in Summary of Activities 2015, Canada-Nunavut Geoscience Office, p. 73-88.

Gervais, F., Brown, R.L., Crowley, J.L. 2010: Tectonic implications for a Cordilleran orogenic base in the Frenchman Cap dome, southeastern Canadian Cordillera. Journal of Structural Geology 32, 941e959. 
Gibb, R. A. \& Walcott, R. I. 1971: A Precambrian suture in the Canadian Shield. Earth and Planetary Science Letters, 10, 417-422.

Hinchey, A.M., Carr, S.D., McNeill, P.D., Rayner, N. 2006: Paleocene Eocene high grade metamorphism, anatexis, and deformation in the Thor-Odin dome, Monashee Complex, southeastern British Columbia. Canadian Journal of Earth Sciences 43, 1341e1365.

Hoffman, P. F. 1988: United Plates of America, the birth of a craton: Early Proterozoic assembly and growth of Laurentia. Annual Review of Earth and Planetary Sciences 16, 543-603.

Holdsworth R. E., Strachan R. A., Alsop G. I. 2001: Geology of the Tongue District (Memoir of the British Geological Survey, HMSO).

Jackson, G.D., Hunt, P.A., Loveridge, W.D., Parrish, R.R. 1990: Reconnaissance geochronology of Baffin Island, N.W.T. Radiogenic Age and Isotopic Studies: Report 3, Geological Survey of Canada, Paper 89-2, pp. 123-148.

Journeay, J.M. 1986: Stratigraphy, internal strain and thermo-tectonic evolution of northern Frenchman Cap dome: an exhumed duplex structure, Omineca hinterland, S.E. Canadian Cordillera. Ph.D. thesis, Queens University.

Kruse, S., McNeill, P.D., Williams, P.F. 2004: Geological map of the Thor-Odin dome, southern Monashee complex, BC. http://www.unb.ca/fredericton/science/geology/monashee.

Law, R. D. 1987: Heterogeneous deformation and quartz crystallographic fabric transitions; natural examples from the Moine thrust zone at the Stack of Glencoul, northern Assynt. Journal of Structural Geology 9, 819-833.

Law, R. D., Casey, M. and Knipe, R. J. 1986: Kinematic and tectonic significance of microstructures and crystallographic fabrics within quartz mylonites from the Assynt and Eriboll regions of the Moine Thrust Zone, NW Scotland. Transactions of the Royal Society of Edinburgh: Earth Sciences 7, 99-125.

Law, R. D., Knipe, R. J. and Dayan, H. 1984: Strain path partitioning within thrust sheets: microstructural and petrofabric evidence from the Moine thrust zone at Loch Eriboll, North-West Scotland. Journal of Structural Geology 6, 477-497. 
Leblanc-Dumas, J., Allard, M. and Tremblay, T. 2013: Quaternary geology and permafrost characteristics in central Hall Peninsula, Baffin Island, Nunavut; in Summary of Activities 2012, Canada-Nunavut Geoscience Office, p. 101-108.

Leblanc-Dumas, J., Allard, M. and Tremblay, T. 2015: Characteristics of a preglacial or interglacial regolith preserved under nonerosive ice during the last glacial maximum in central Hall Peninsula, southern Baffin Island, Nunavut; in Summary of Activities 2014, Canada-Nunavut Geoscience Office, p. 69-78.

Le Maitre, R. W., (Ed.) et al. 1989: A Classification of Igneous Rocks and Glossary of Terms. Recommendations of the International Union of Geological Sciences, Subcommission on the Systematics of Igneous Rocks. Blackwell, Oxford. 193pp.

Le Maitre, R. W., (Ed.) et al. 2002: A Classification of Igneous Rocks and Glossary of Terms. Recommendations of the International Union of Geological Sciences, Subcommission on the Systematics of Igneous Rocks. Cambridge University Press. 236pp.

Lewry, J. F. \& Collerson, K. D. 1990: The Trans- Hudson Orogen: extent, subdivisions and problems. In: LEWRY, J. F. \& STAUFFER, M. R. (eds) The Early ProteFraynerrozoic Trans-Hudson Orogen of North America. Geological Association of Canada, Special Paper, 37, 1-14.

Liikane, D.A., St-Onge, M.R., Kjarsgaard, B.A., Rayner, N.M., Ernst, R.E. and Kastek, N. 2015: Frobisher suite mafic, ultramafic and layered mafic-ultramafic sills, southern Baffin Island, Nunavut; in Summary of Activities 2015, Canada-Nunavut Geoscience Office, p. $21-32$.

Machado, G., Bilodeau, C., Takpanie, R., St-Onge, M.R., Rayner, N.M., Skipton, D.R., From, R.E., MacKay, C.B., Creason, C.G. and Braden, Z.M. 2013a: Hall Peninsula regional bedrock mapping, Baffin Island, Nunavut: summary of fieldwork; in Summary of Activities 2012, Canada-Nunavut Geoscience Office, p. 13-22.

Machado, G., Bilodeau, C. and St-Onge, M.R. 2013b: Geology, southern part of Hall Peninsula, south Baffin Island, Nunavut; Geological Survey of Canada, Canadian Geoscience Map 
135 (preliminary); Canada-Nunavut Geoscience Office, Open File Map 2013-1, scale 1:250 000. doi:10.4095/292443.

MacKay, C.B. and Ansdell, K.M. 2014: Geochemical study of mafic and ultramafic rocks from southern Hall Peninsula, Baffin Island, Nunavut; in Summary of Activities 2013, Canada-Nunavut Geoscience Office, p. 85-92.

MacKay, C.B., Ansdell, K.M., St-Onge, M.R., Machado, G. and Bilodeau, C. 2013: Geological relationships in the Qaqqanittuaq area, southern Hall Peninsula, Baffin Island, Nunavut; in Summary of Activities 2012, Canada-Nunavut Geoscience Office, p. 55-64.

McClay, K. R. and Coward, M. P. 1981: The Moine Thrust Zone: an overview. In: Thrust and Nappe Tectonics (edited by McClay, K. R. and Price, N. J.) 9. Special Publications of the Geological Society of London, London, 241-260.

McClay, K. R. 1987: The Mapping of Geological Structures. Milton Keynes, England: Open UP. .Print.

Minnigh, L.D., 1979: Structural-analysis of sheath-fold in meta-chert from the Western Italian Alps. Journal of Structural Geology 1 (4), 275e282.

Nichols, K.M.A., Stachel, T., Pell, J. A. and Mate, D.J. 2013: Diamond sources beneath the Hall Peninsula, Baffin Island, Nunavut: preliminary assessment based on microdiamonds; in Summary of Activities 2012, Canada-Nunavut Geoscience Office, p. 113-120.

Passchier, C. W., and Trouw, R. A. J. 2005: Microtectonics. 2nd Edition ed. Berlin: Springer, Print.

Pell, J., Grütter, H., Neilson, S., Lockhart, G., Dempsey, S. and Grenon, H. 2013: Exploration and discovery of the Chidliak kimberlite province, Baffin Island, Nunavut: Canada's newest diamond district; in Proceedings of 10th International Kimberlite Conference, D.G. Pearson (ed.), Geological Society of India, Special Issue, v. 2, p. 209-227, doi: 10.1007/978-81-322-1173-0-14.

Philpotts, A.R. 1990: Principles of Igneous and Metamorphic Petrology, Prentice-Hall Publishing Co., 490 p. 
Ramsay, J. G. 1969: The measurement of strain and displacement in orogenic couplets. In: Time and Place Orogeny (edited by Kent, P. E., Satterthwaite, G. E. and Spencer, A. M.) 3, 43-79.

Ramsay, J.G. 1997: The geometry of a deformed unconformity in the Caledonides of NW Scotland. In: Evolution of geological structures in micro- to macro-scales (edited by S. Sengupta). Chapman \& Hall, London, 445-472.

Rathbone, P.A., Coward, M.P. \& Harris, A. L. 1983: Cover and basement: a contrast in style and fabrics. In: Harris, L.D., Williams, H. \& Zietz, 1. (eds). Tectonics and geophysics of Mountain Chains. Mem. Geol. Soc. Amer. 158, 213 - 223.

Rayner, N.M. 2014: New U-Pb geochronological results from Hall Peninsula, Baffin Island, Nunavut; in Summary of Activities 2013, Canada-Nunavut Geoscience Office, p. 3953.

Rayner, N.M., St-Onge, M.R., and Miles, W.F. 2014: Report of Activities for Completing the Regional Bedrock Mapping of the southern half of Baffin Island: GEM 2 Baffin Project; Geological Survey of Canada, Open File 7704, 9p. doi:10.4095/295525.

Rayner, N.M. 2015: New (2013-2014) U-Pb geochronological results from northern Hall Peninsula, southern Baffin Island, Nunavut. In: Summary of Activities 2014, CanadaNunavut Geoscience Office, 31-44.

Rayner, N.M., Machado, G., Bilodeau, C. and St-Onge, M.R. 2013: Uranium-lead geochronological studies of Hall Peninsula, Baffin Island, Nunavut: contributions to mapping and tectonics; in Summary of Activities 2012, Canada-Nunavut Geoscience Office, p. 23-28.

Reesor, J.E., Moore Jr., J.M. 1971: Petrology and Structure of Thor-Odin Gneiss Dome, Shuswap Metamorphic Complex, British Columbia. In: Geological Survey of Canada Paper, vol. 195, 149 pp.

Rey, P.F., Vanderhaeghe, O., Teyssier, C. 2001: Gravitational collapse of the continental crust: definition, regimes and modes. Tectonophysics 342, 435e449. Rey, P.F., Teyssier, C., 
Whitney, D.L., 2009. Extension rates, crustal melting, and core complex dynamics. Geology 37, 391e394.

Rogers, J.J.W., Santosh, M. 2002: Configuration of Columbia, a Mesoproterozoic supercontinent. Gondwana Res 5:5-22.

Ross, G.M., Parrish, R.R. 1991: Detrital zircon geochronology of metasedimentary rocks in the southern Omineca Belt, Canadian Cordillera. Canadian Journal of Earth Sciences 28, $1254 \mathrm{e} 1270$.

Schmid, R., Fettes, D., Harte, B., Davis, E., and Desmons, J. 2007: A systematic nomenclature for metamorphic rocks. 1. How to name a metamorphic rock. Recommendations by the IUGS Subcommission on the systematics of metamorphic rocks. SCMR website (www.bgs.ac.uk/SCMR).

Scott, D.J. \& Wodicka, N. 1998: A second report on the U-Pb geochronology of southern Baffin Island. Geological Survey of Canada, Paper 1998-F, 47-57.

Scott, D.J. 1996: Geology of the Hall Peninsula east of Iqaluit, southern Baffin Island; in Current Research 1996-C, Geological Survey of Canada, p. 83-91.

Scott, D. J. 1997: Geology, U-Pb, and Pb-Pb geochronology of the Lake Harbour area, southern Baffin Island: Implications for the Paleoproterozoic tectonic evolution of north-eastern Laurentia, Can. J. Earth Sci., 34, 140 - 155.

Scott, D.J. 1999: U-Pb geochronology of the eastern Hall Peninsula, southern Baffin Island, Canada: a northern link between the Archean of West Greenland and the Paleoproterozoic Torngat Orogen of northern Labrador; Precambrian Research, v. 93, p. 5-26.

Sills, J.D. and Rollinson, H.R. 1987: Metamorphic evolution of the mainland Lewisian complex. In: Park, R.G. and Tarney, J (eds), Evolution of the Lewisian and comparable Precambrian High Grade Terrains, Geological Society of London Special Publication No. $27,81-92$. 
Simony, P.S., and Carr, S.D. 2011: Cretaceous to Eocene evolution of the southeastern Canadian Cordillera: Continuity of rocky mountain thrust systems with zones of "in-sequence" mid-crustal flow. Journal of Structural Geology, 33: 1417-1434. doi:10.1016/j.jsg.2011.06.001.

Skipton, D.R. and St-Onge, M.R. 2014: Paleoproterozoic deformation and metamorphism in metasedimentary rocks west of Okalik Bay: a field template for the evolution of eastern Hall Peninsula, Baffin Island, Nunavut; in Summary of Activities 2013, CanadaNunavut Geoscience Office, p. 63-72.1

Skipton, D.R., Schneider, D. A. and St-Onge, M.R. 2013: Preliminary observations on Archean and Paleoproterozoic metamorphism and deformation of the southern Hall Peninsula, Baffin Island, Nunavut; in Summary of Activities 2012, Canada-Nunavut Geoscience Office, p. 29-42.

Skipton, D.R., Schneider, D.A., Kellett, D. \& Joyce, N. 2015: New insights on the cooling history of Hall Peninsula, southern Baffin Island, Nunavut, using 40Ar/39Ar thermochronology on muscovite. In: Summary of Activities 2014, Canada-Nunavut Geoscience Office, 17-30.

Skipton, D.R., St-Onge, M.R., Schneider, D.A. \& McFarlane, C.R.M. 2016: Tectonothermal evolution of the middle crust in the Trans-Hudson Orogen, Baffin Island, Canada; evidence from petrology and monazite geochronology of sillimanite-bearing migmatites. Journal of petrology. (57)8. p.1437 - 1462.

Spalla, M.I., Zanoni, D., Williams, P.F., and Gosso, G. 2011: Deciphering cryptic P-T-d-t histories in the western Thor-Odin dome, Monashee Mountains, Canadian Cordillera: A 
key to unravelling pre-Cordilleran tectonic signatures: Journal of Structural Geology, v. 33, p. 399-421, doi:10.1016/j.jsg.2010.11.014.

Stauffer, M. R. 1984: Manikewan and early Proterozoic ocean in central Canada, its igneous history and orogenic closure. Precambrian Research, 25, 257-281.

Steenkamp, H.M. and St-Onge, M.R. 2014: Overview of the 2013 regional bedrock mapping program on northern Hall Peninsula, Baffin Island, Nunavut; in Summary of Activities 2013, Canada-Nunavut Geoscience Office, p. 27-38.

Steenkamp, H.M., Bros, E.R. and St-Onge, M.R. 2014: Altered ultramafic and layered maficultramafic intrusions: new economic and carving stone potential on northern Hall Peninsula, Baffin Island, Nunavut; in Summary of Activities 2013, Canada-Nunavut Geoscience Office, p. 11-20.

St-Onge, M. R., Searle, M. P. \& Wodicka, N. 2006: Trans-Hudson Orogen of North America and Himalaya-Karakoram-Tibetan Orogen of Asia: Structural and thermal characteristics of the lower and upper plates. Tectonics, 25.

St-Onge, M.R., Rayner, N.M., Liikane, D. and Chadwick, T. 2015: Mafic, ultramafic and layered mafic-ultramafic sills, Meta Incognita Peninsula, southern Baffin Island, Nunavut; in Summary of Activities 2014, Canada-Nunavut Geoscience Office, p. 11-16.

St-Onge, M.R., Scott, D.J. \& Lucas, S.B. 2000: Early partitioning of Quebec: microcontinent formation in the Paleoproterozoic. Geology 28, 323-326.

St-Onge, M.R., Scott, D.J. and Wodicka, N. 2002: Review of crustal architecture and evolution in the Ungava Peninsula-Baffin Island area: connection to the Lithoprobe ECSOOT transect; Canadian Journal of Earth Sciences, v. 39, p. 589-610.

St-Onge, M.R., Van Gool, J.A.M., Garde, A.A. and Scott, D.J. 2009: Correlation of Archaean and Palaeoproterozoic units between northeastern Canada and western Greenland: constraining the pre-collisional upper plate accretionary history of the Trans-Hudson orogen; Geological Society, London, Special Publication 318, p. 193-235. 
St-Onge, M.R.,Wodicka, N. and Ijewliw, O. 2007: Polymetamorphic evolution of the TransHudson Orogen, Baffin Island, Canada: integration of petrological, structural and geochronological data; Journal of Petrology, v. 48, p. 271-302, doi: 10.1093/petrology/eg1060.

Strachan R. A., Holdsworth R. E. 1988: Basement-cover relationships and structure within the Moine rocks of central and southeast Sutherland. Journal of the Geological Society, London 145:23-36.

Streckeisen, A. L. 1974: Classification and Nomenclature of Plutonic Rocks. Recommendations of the IUGS Subcommission on the Systematics of Igneous Rocks. Geologische Rundschau. Internationale Zeitschrift für Geologie. Stuttgart. Vol.63, p. 773-785.

Tremblay, T., Leblanc-Dumas, J. and Allard, M. 2015: Geochemistry, mineralogy and sedimentology of surficial sediments, Hall Peninsula, southern Baffin Island, Nunavut; in Summary of Activities 2014, Canada-Nunavut Geoscience Office, p. 57-68.

Tremblay, T., Leblanc-Dumas, J., Allard, M., Gosse, J.C., Creason, C.G., Peyton, P., Budkewitsch, P. and LeBlanc, A.M. 2013: in Summary of Activities 2012, CanadaNunavut Geoscience Office, p. 93-100.

Tremblay, T., Leblanc-Dumas, J., Allard, M., Ross, M. and Johnson, C. 2014: Surficial geology of central Hall Peninsula, Baffin Island, Nunavut: summary of the 2013 field season: in Summary of Activities 2013, Canada-Nunavut Geoscience Office, p. 109-120.

Turner, F.J., Weiss, L.E. 1963: Structural Analysis of Metamorphic Tectonites. McGraw-Hill (New York).

Twiss, R. J., and Moores, E. M. 2007: Structural Geology. 2nd Edition. New York: Freeman, Print.

van Breeman, O., A. Davidson, W. D. Loveridge, and R. D. Sullivan. 1986: U-Pb zircon geochronology of Grenvillian tectonites, granulites and igneous precursors, Parry Sound, Ontario, in The Grenville Province, Geological Association of Canada, Spec. Pap., 31, pp. 191-207. 
Vectors and tensors in structural geology: Cambridge University Press (book to Whalen, J.B., Wodicka, N., Taylor, B.E. \& Jackson, G.D. 2010: Cumberland Batholith, TransHudson Orogen, Canada: Petrogenesis and implications for Paleoproterozoic crustal and orogenic processes. Lithos 117, 99-118.

White, S. H. 1977: Geological significance of recovery and recrystallization processes in quartz. Tectonophysics 39, 143-170.

White, S. H. 1979: Grain and sub-grain size variations across a mylonite zone. Contributions to Mineralogy and Petrology 70, 193-202.

White, S. H. 1982: Fault rock in the Moine Thrust Zone: a guide to their nomenclature. Textures and Microstructures 4, 21-221.

White, S.H., Burrows S.E., Carreras, J., Shaw, N.D., Humphreys, F.J. 1980: On mylonites in ductile shear zones. Journal of Structural Geology, Volume 2, Issue 1, Pages 175-187

Whitney, D.L., and Evans, B.W. 2010: Abbreviations for names of rock-forming minerals. American Mineralogist 95 (1): 185-187.

Wibberley, C.A.J. 1997: Three-dimensional geometry, strain rates and basement deformation mechanisms of thrust-bend folding. Journal of Structural Geology, 19, 535-550.

Wilson, G. 1953. Mullions and rodding structures in the Moine Series of Scotland. Proceedings of the Geologists' Association 64, 118-151.

Wodicka, N., J. W. F. Ketchum, and R. A. Jamieson. 2000: Grenvillian metamorphism of monocyclic rocks, Georgian Bay, Ontario, Canada: Implications for convergence history, Can. Mineral., 38, 471-510.

Wodicka, N., R. R. Parrish, and R. A. Jamieson. 1996: The Parry Sound domain; a far-travelled allochthon? New evidence from U-Pb zircon geochronology, Can. J. Earth Sci., 33, 1087-1104.

Zhang, S. and Pell, J. 2013: Study of sedimentary rock xenoliths from kimberlites on Hall Peninsula, Baffin Island, Nunavut; in Summary of Activities 2012, Canada-Nunavut Geoscience Office, p. 107-112. 


\section{APPENDIX A- ESTIMATING THE STRIKE AND DIP OF CONTACTS USING STRUCTURE CONTOURS}

Structure contours are created using the intersection of planar features (i.e. geological contacts) with topography (Figure 9.3, p.143 in McClay, 1987). By drawing a line between two points on a geological surface that are at the same elevation, the intersection of a horizontal plane with the surface is defined, and thus the strike of that surface. By definition, dip is perpendicular to strike, and by using the rule of V's one can determine the direction of dip. To determine the angle of dip, strike lines at different elevations must be used. To determine the dip, the horizontal map distance over which the geologic surface drops one contour interval in elevation must be measured. Then the gradient can be calculated by dividing the change in elevation by the map distance. Finally, the dip angle is calculated by taking the inverse tangent of the gradient. 


\section{APPENDIX B- STEREONET ANALYSIS OF POLYPHASE FOLDS (USING}

\section{DATA FROM THIS STUDY AS AN EXAMPLE)}

Stereonet analysis of planar and linear orientation data is a vital tool for determining the geometry of fold structures, especially in terranes that have experienced polyphase folding, such as the Ptarmigan Fiord area. Stereograms in this study were plotted using the open source program 'Stereonet' (v.9.5.1), which incorporates algorithms from Allmendinger et al. (2013) and Cardoza and Allmendinger (2013). For more information about manipulating and plotting structural data using this program, please refer to the Stereonet 9.5 help manual found at: http://www.geo.cornell.edu/geology/faculty/RWA/programs/stereonet-help.pdf.

Geometrical components of folds useful for their classification, which can be determined using stereonet analysis include: the axial surface and fold axis orientations, and the interlimb angle. The geometry of an individual fold is determined by looking at planar orientation data from both limbs and the hinge of the fold. Great care must be taken to not include limb or hinge data from other folds in the analysis, or else false fold geometries could be created. When studying map-scale folds, choosing appropriate domains within the study area that contain orientation measurements (preferably from both limbs and the hinge) relating to one fold structure of interest can be challenging. However, studying the map pattern and choosing areas with only one map-scale fold can help guide the location for subdomains for data sampling. Data coverage plays a significant factor when choosing subdomains, but estimated strikes and dips can be determined using the method stated above. However, the validity of the estimated orientation must be questioned when basing it off interpreted map patterns. For more details about using estimated orientation data, refer to the individual fold descriptions in the following section. 
If a stereogram is plotted using poles to all the planar $\mathrm{S}_{2 \mathrm{a}}$ measurements from the entire synclinal keel map pattern in the southeast domain, in an attempt to roughly characterize the map-scale upright synclinal fold, the resulting stereogram would have 'smeared' clusters of points in the NE and SW hemispheres. The 'smearing' or poor clustering of the points is due to multiple fold structures, with different geometries, influencing the orientation of $\mathrm{S}_{2 \mathrm{a}}$ within the sampled domain. So in order to characterize just one fold generation, much narrower domains of data need to be chosen.

For example, the hinge area of the synclinal keel map pattern (Figure 3.6, subdomain C), is a preferable area to sample orientation data for the $F_{2 b}$ (SE) upright synclinal fold, because both limbs and hinge orientations are available. Also, the narrow width of the subdomain helps to minimize the effect of other fold structures on the analysis; the limbs and hinge at this subdomain scale do not appear bent or folded on the map.

The result is a tight cluster of poles to $S_{2 \mathrm{a}}$ measurements (small circles, Figure 3.6), and calculated contact orientations (large circles) lying on pi-girdle (solid lines), allowing for the axial surface (dashed lines), fold axis (triangles) of the $\mathrm{F}_{2 \mathrm{~b}}$ (SE) fold to be determined accurately in this part of the map. If the $\mathrm{S}_{2 \mathrm{a}}$ data and calculated orientations fall onto separate pi-girdles (i.e. subdomains D \& E, Figure 3.6), a second fold axis (diamonds) is calculated for the calculated orientations pi-girdle. The mean vectors for the $\mathrm{S}_{2 \mathrm{a}}$ measurements (squares) were calculated using a Fisher Vector Distribution, which is detailed in the statistical analysis section. The best fit great circles assigned to the pi-girdles and axial surfaces were derived using a Bingham Axial Distribution, which is also detailed in the statistical analysis section.

The process is repeated along the entirety of the synclinal keel structure up to the first subdomain (Figure 3.6, subdomain A), and the resulting stereograms show a fold axis and axial 
surface orientation change across the structure. This orientation change indicates that a younger structure has modified the $F_{2 b}$ (SE) syncline. Plotting the poles to axial surfaces of the $F_{2 b}$ (SE) folds in subdomains $\mathrm{A}-\mathrm{C}$ on a stereogram, treating the $\mathrm{A} \& \mathrm{C}$ subdomains as limbs and the $\mathrm{C}$ subdomain as a hinge, the geometry of a younger gentle, steeply inclined, and steeply westplunging fold is determined $\left(\mathrm{F}_{3 \mathrm{~b}}\right)$.

This general method was used for the stereonet analysis of the entire Ptarmigan Fiord area, and the results outlined the geometries of multiple phases of folding. For more information about fold-specific stereonet analysis, refer to the structural description below for each fold generation. 


\section{APPENDIX C- STATISTICAL ANALYSIS USED IN STEREONET 9.5}

\section{Fisher Vector Distribution}

This is a standard mean vector calculation, which simply adds up all of the direction cosines of all of the individual unit vectors (Fisher et al., 1987). The reported mean length is just the length of the resultant vector $(\mathrm{R})$ divided by the summed number of vectors $(\mathrm{N})$. The reported trend and plunge are calculated from the resultant vector normalized to a unit vector. Uncertainty intervals can be calculated using the following equation:

$$
\cos \delta \alpha_{p}=1-\left(\frac{N-R}{R}\right)\left[\left(\frac{1}{1-p}\right)^{\frac{1}{N-1}}-1\right]
$$

Where $p$ is the probability, $N$ is the number of observation, and $R$ is the resultant vector length. The dispersion and concentration factor $(\kappa)$, is calculated from one of the following calculations:

$$
\begin{aligned}
& \kappa \approx\left(\frac{N}{(N-R)}\right)\left(1-\left(\frac{1}{N}\right)\right)^{2} \quad \text { for } N<16 \\
& \kappa \approx \frac{(N-1)}{(N-R)} \quad \text { for } N \geq 16
\end{aligned}
$$

In the case of the lower equation, the literature uses either $(N-1)$ or $(N-2)$ in the numerator. The program Stereonet uses $(N-1)$ following the original estimation of Fisher et al. (1987), but other programs and authors use $(N-2)$ (e.g. Davis, 2002). 


\subsubsection{Bingham Axial Distribution}

Unlike the Fisher vector distribution, the Bingham axial distribution finds the mean vectors of axes data rather than lines (Davis, 2002). It is commonly used to determine the cylindrical best fit determination of fold axes. The analysis works by calculating the orientation tensor:

$$
\mathbf{T}=\left[\begin{array}{ccc}
\sum \cos ^{2} \alpha_{[i]} & \sum \cos \alpha_{[i]} \cos \beta_{[i]} & \sum \cos \alpha_{[i]} \cos \gamma_{[i]} \\
\sum \cos \beta_{[i]} \cos \alpha_{[i]} & \sum \cos ^{2} \beta_{[i]} & \sum \cos \beta_{[i]} \cos \gamma_{[i]} \\
\sum \cos \gamma_{[i]} \cos \alpha_{[i]} & \sum \cos \gamma_{[i]} \cos \beta_{[i]} & \sum \cos ^{2} \gamma_{[i]}
\end{array}\right]
$$

from the direction cosines of the individual measurements and then calculating the eigenvalues and eigenvectors to get a principal axes of the tensor. The first axis deals with the highest concentration of points, the second with the intermediate concentration, and the third to the lowest concentration. The third axis is usually interpreted as the cylindrical fold axis. Stereonet calculates the semi-major and minor axes of the error ellipses around each principal axis, when more than 25 points are used, following the procedure outlined in Fisher et al. (1987). 


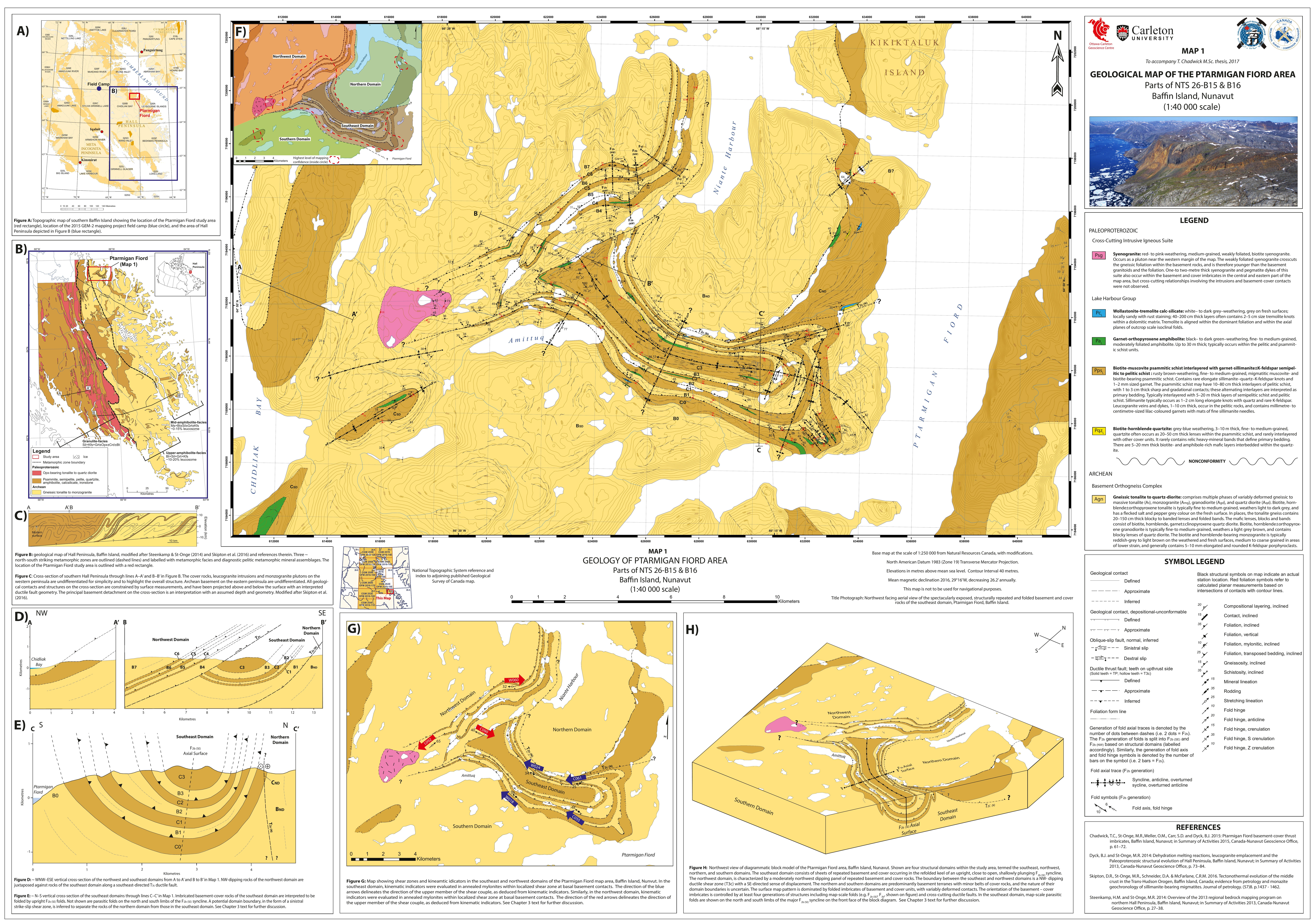




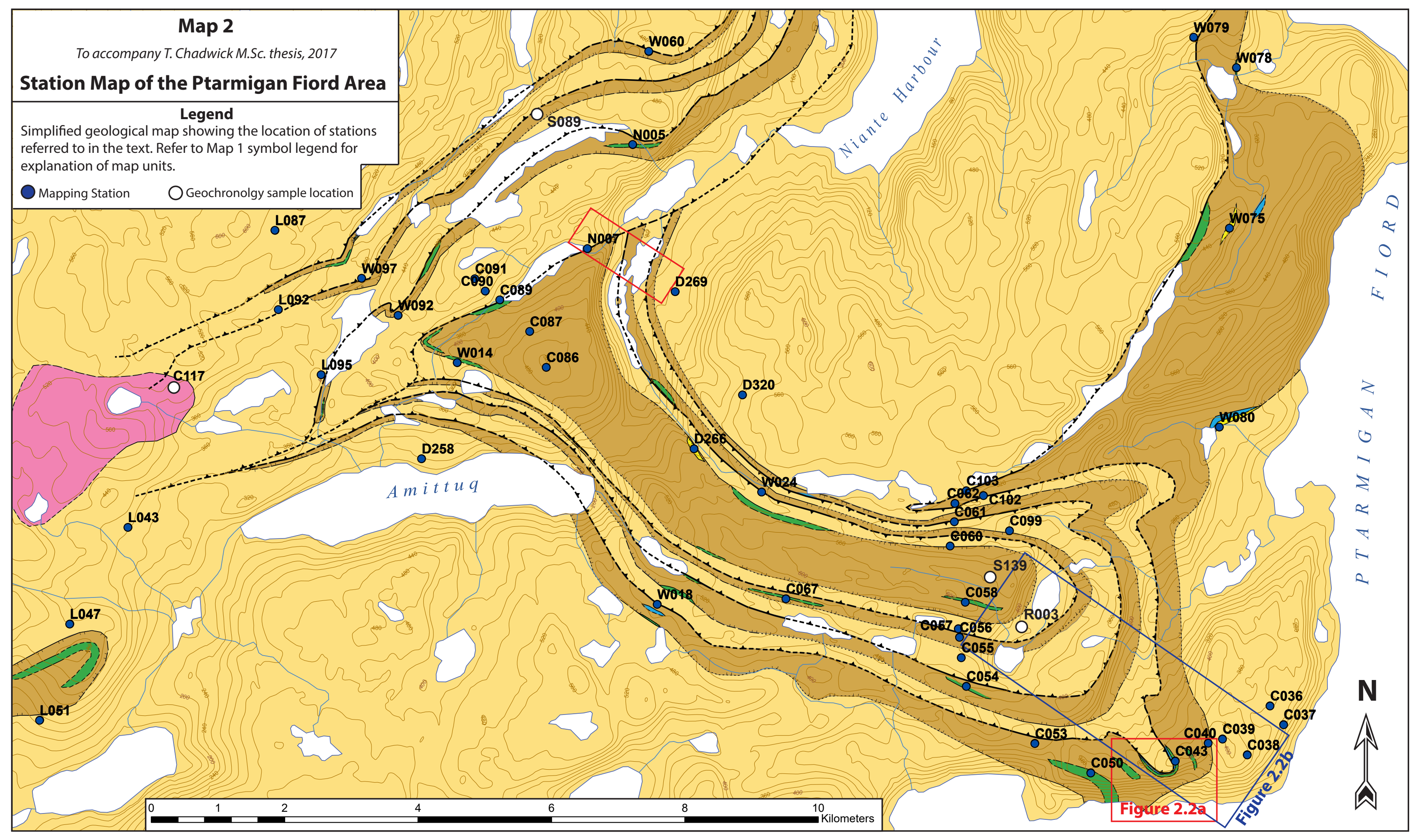

